\title{
God and Humans in Islamic Thought
}

The explanation of the relationship between God and humans, as portrayed in Islam, is often influenced by the images of God and of human beings which theologians, philosophers and mystics have in mind. The early period of Islam discloses a diversity of interpretations of this relationship. Thinkers from the tenth- and eleventh century had the privilege of disclosing different facets of the relationship between humans and the Divine.

God and Humans in Islamic Thought discusses the view of three different scholars of the time: 'Abd al-Jabbār, Ibn Sīnā and al-Ghazālī. The relationships discussed in this work are: divine assistance, lutf, according to 'Abd al-Jabbār; human love and attraction to the Divine, 'ishq, according to Ibn Sīnā; and finally the mystical annihilation of the self in the divine unity, fan $\bar{a}$, of al-Ghazālī. They introduced three approaches of looking at this relationship. In order to perceive these concepts, their perception of God and of the human nature will also be examined here. The starting point of this research was the desire to set forth a variety of possible relationships which are all in accordance with Islamic belief but nevertheless demonstrate diversity in understanding the relationship between the human and the Divine which in turn suggests the concept of plurality within one religion.

Examining these three concepts, which build firm connections between God and humans, reveals the importance of rational inquiry in medieval Islamic thought, not only because it was a source of logical arguments for Islam against its opponents, but mainly because it built different bridges leading to God. God and Humans in Islamic Thought attempts to shed light on an important aspect of medieval rational thought in demonstrating its significance in forming the basis of an understanding of the nature of God, the nature of human beings and the construction of different bridges between them.

Maha Elkaisy-Friemuth is currently a Post-Doctoral Research Fellow at Trinity College, Dublin and was formerly a lecturer at Manchester University. Her field of interest is the Islamic medieval thought and its intellectual influence on formulating Islam. Publications include "Al-Radd al-Jamīl: Ghazālī or pseudo-Ghazālī" in ed. David Thomas, The Bible in Arab Christianity, Leiden: Brill, forthcoming; 64 entries in the Encyclopaedia for Islamic Religion, Routledge, 2005; and 9 entries in the Dictionary of Islamic Philosophers, Theommes Press, forthcoming. 
Culture and Civilization in the Middle East

Series Editor

Ian R. Netton

University of Leeds

This series studies the Middle East through the twin foci of its diverse cultures and civilizations. Comprising original monographs as well as scholarly surveys, it covers topics in the fields of Middle Eastern literature, archaeology, law, history, philosophy, science, folklore, art, architecture and language. Although there is a plurality of views, the series presents serious scholarship in a lucid and stimulating fashion. 


\section{God and Humans in Islamic Thought}

'Abd al-Jabbār, Ibn Sīnā and al-Ghazālī

Maha Elkaisy-Friemuth 
First published 2006 by Routledge

Published 2017 by Routledge

2 Park Square, Milton Park, Abingdon, Oxon OX14 4RN

711 Third Ave, New York, NY 10017, USA

Routledge is an imprint of the Taylor E Francis Group, an informa business

Copyright @ 2006 Maha Elkaisy-Friemuth

Typeset in Garamond by

Newgen Imaging Systems (P) Ltd, Chennai, India

The Open Access version of this book, available at

www. tandfebooks. com, has been made available under a

Creative Commons Attribution-Non Commercial-No

Derivatives 4.0 license.

British Library Cataloguing in Publication Data

A catalogue record for this book is available

from the British Library

Library of Congress Cataloging in Publication Data

A catalog record for this book has been requested

ISBN13: 978-0-415-40028-2 (hbk) 
To my husband and my children 



\section{Contents}

Acknowledgements $\quad$ ix

Introduction 1

1 Historical and cultural context 9

Political and cultural development 9

The life and works of 'Abd al-Jabbār, Ibn Sin̄ā

and al-Ghazālì 20

Development of luṭf, 'ishq and fanā' 35

2 'Abd al-Jabbār's view of the relationship with God through divine assistance, lutf

The main characteristics of God 42

Human nature and the different ways of knowledge 52

Communication through God's duty of assistance, luṭ 62

Conclusion 72

3 Relationship with God through knowledge and love, 'ishq, in the philosophy of Ibn Sīnā

The main characteristics of God 79

The features of humans 90

Relationship with God through His manifestation

of Himself, Tajallī 102

Conclusion 116

4 Relationship with God through self-annihilation, fanā', according to al-Ghazālī

The features of God according to al-Ghazātī 121

The features of the buman soul 129 
viii Contents

Al-Ghazālin's mystical approach to the relationship with God 137

Conclusion 150

5 Comparison and evaluation

God and bumans in 'Abd al-Jabbār, Ibn Sīnā and al-Ghazātī 152

Evaluation 168

Conclusion 171

Notes

Bibliography

203

Index 


\section{Acknowledgements}

Many people have contributed in one way or another to the preparation of this study. I would like to thank, first of all, the staff members of the Centre for Islamic Studies and Christian-Muslim Relations at Birmingham University. I would like above all to express my deep regard for Dr David Thomas for his supervision and encouragement to me in all stages of the work.

I also would like to express my deep gratitude to Prof. Ian Richard Netton for reading this work in all its previous versions and for his support and guidance. It is important to mention here also the effort of Prof. Oliver Leaman, who read this work in its version as $\mathrm{PhD}$ thesis and gave a clear guidance for its conversion to a book. For this I thank him deeply.

I would also like to express my deepest regards and thanks to Dr Eve Richards for editing this work and constantly encouraging me while reading each chapter.

Finally, my sincere thanks to professors John Dillon and Sean Freyne of Trinity College Dublin where I hold a Postdoctoral Fellowship at the Centre for Mediterranean \& Near Eastern Studies, a project funded by the Irish Government's Programme for Research in Third Level Institutions. 



\section{Introduction}

The deepest aim of religions is to disclose the relationship between God and humans; in their religions, all people seek possible ways to approach God and God reveals different ways of communication with Him. In Islam the Qur'ān reveals certain characteristics of God and of human beings which present a variety of relationships between them. God on the one hand is transcendent: "There is nothing whatever like unto Him" (42:11); and "Say He is God the One the Only, God the Eternal the Absolute" (112:1-2). ${ }^{1}$ However, at the same time He is also immanent: "God knoweth well the secrets of your heart" (5:8), and also mysterious: "Whithersoever ye turn there is the presence of God" (2:115). ${ }^{2}$ Human beings, according to the Qur'ān, are, on the other hand, totally different from God - "For man was created weak" (4:28); "Truly man was created very impatient, fretful when evil touches him; and niggardly when good reaches him" (70:19-21). But yet other parts of the Qur'ān declare great similarities between the two natures - "I have fashioned him (in due proportion) and breathed into him of My Spirit" (15:29); ${ }^{3}$ and "Thy Lord said to the angels: I will create a vicegerent on earth" (2:30). Accordingly, a variety of relationships can follow, such as "I have only created jinns and men, that they may serve Me" (51:56); "He who taught (the use of the) pen, taught man that which he knew not" (96:4-5) or "We are nearer to him than the jugular vein" (50:16). These relationships emphasize different tendencies in the obeying of the law, the interaction between human and divine knowledge, and also the experience of mystical union.

The starting point of this research, then, was the author's desire to set forth a variety of possible relationships which are all in accordance with Islamic belief but nevertheless demonstrate diversity in understanding the relationship between the human and the divine. These varieties, I believe, could introduce the concept of plurality within one religion. In this book, therefore, I will present three different approaches within Islam to interpreting the relationship between God and humanity. These approaches are taken here by three rational thinkers from the tenth and eleventh centuries, who represent three important schools of thinking of the time: the Mu'tazilites, the school of Islamic philosophers and the mystics. 


\section{Introduction}

One common element which draws these schools together is their use, though in different degrees, of Greek philosophy, which was widely known among the scholars of the period. This appears mainly in their approach to understanding God as an immaterial unity which transcends everything in the world. This approach is in no way in conflict with the Qur'ānic image of God; indeed, it corresponds to many verses such as the one which is frequently quoted by those groups "There is nothing whatever like unto Him" (42:11). The nature of God is discussed in Islam under the subject of the attributes of God. This discussion started among the Mu'tazilites after its basis was laid down by Abū al-Hudhayl, the father of the Basrian school. He asserted that all God's attributes are identical to His essence and therefore His unity is ensured. Divine knowledge and power are not distinct from God but are rather God Himself. In the same manner the first philosopher of the Arabs, al-Kindī (d. AD 866), approached the unity of God using the concept of negative attributes: God's knowledge means the absence of ignorance. This concept goes a step further to demonstrate the difficulty of attributing human qualities to God and asserts His absolute otherness.

The Baghdād school of mysticism was founded by Sarī al-Saqtī and was Neoplatonic in tendency. Its leader, al-Junayd (d. AD 910) discussed the nature of God under his concept of unification, tawhid $\bar{i}$, and placed the unity of God within the cycle of creation and return. All souls were produced in God's essence and were separated from Him through the process of creation. The unification with God is therefore the hope to return to the divine source and is the true expression of the Islamic concept of tawhi $\bar{\imath} d$, the unity of God.

Their understanding of the nature of the human was also influenced by Greek philosophical theories. Theologians by the end of the ninth century had adopted the theory of atomism in their interpretation of the nature of bodies. Abū al-Hudhayl was the first to introduce this theory, but with much modification. Atoms, the smallest indivisible part, which he also called jawhar, function in a body only when some attributes come from outside to influence their activity. These attributes are known in Islamic theology as $a^{6} r \bar{a} d$ and in English as accidents. Both atoms and accidents are dynamically created by God. They exist always together and explain the unity function of bodies. This theological theory of the nature of human beings aims to emphasize the inseparability of the body and the spiritual principles, as will be discussed in Chapters 2 and 5 later.

The separation between the soul and body was a feature of interpreting the nature of mankind among the philosophers and the Gnostic mystics. The only eternal part of the human being is the soul. The body is the instrument of the soul and the soul is the intellectual and spiritual element which exists eternally. This theory has its basis in Platonic and Neoplatonic thought, but I shall show throughout this work that, on the one hand, this theory has great affinities to many verses in the Qur'ān which were pondered on by both the philosophers and the mystics. While, on the other hand, many of the mystics asserted great links between the human soul and God, using such 
verses as: "I (God) have fashioned him (in due proportion) and breathed into him of My Spirit" (15:29). These links draw humans directly to God rather than to a collective Universal Soul, as it is known in Neoplatonic thought.

Although these schools agreed, more or less, about the main features of God, they disagreed about the nature of human beings and therefore adopted different approaches to the ways in which God communicated with them. This book, as a result, attempts to present three different approaches to the relationship between the human and the divine according to three scholars from the schools mentioned above: 'Abd al-Jabbār (d. AD 1024) from the Mu'tazilites, Ibn Sīnā (d. AD 1037) as an Islamic philosopher and al-Ghazālī (d. AD 1111) as representative of the mystics.

I have chosen 'Abd al-Jabbār to represent the Mu'tazilites because his works are the most detailed and best preserved of Mu'tazilite works, copies of which were recently found in Yemen. The choice of Ibn Sinnā to represent the philosophers rests on the mystical side of his philosophy and his theory of intuition, which make him more appropriate for discussing the relationship with God. I have attempted here through my choice of al-Ghazālī to present a kind of mysticism which has a rational ground, in order to be able to compare his views on the divine and human nature and the relationship between them. Like 'Abd al-Jabbār and Ibn Sīnā, he also came from Persia and all three were alive in about the same period.

The relationships discussed in this work are as follows: divine assistance, lutf, according to 'Abd al-Jabbār; human love and attraction to the divine, 'ishq, according to Ibn Sīnā and finally the mystical annihilation of the self in the divine unity, fanā', of al-Ghazālī. Examining these three concepts, which build firm connections between God and humans, reveals the importance of rational inquiry in medieval Islamic thought, not just because it was a source of logical arguments for Islam against its opponents, but mainly because it built different bridges leading to God. Many traditional Muslim theologians today tend to put emphasis on the importance of medieval rationalism in supporting and defending Islam against the different non-Muslim rational groups such as the Barāhima, the Sumaniya, the Sabaean and the Christian theologians. The present work, therefore, attempts to shed light on another important side of medieval rational thought in demonstrating its importance in forming the basis of an understanding of the nature of God, the nature of human beings and the construction of different bridges between them. In this, I shall seek to show how those thinkers influenced Islamic thought and made great advances in approaching God and establishing a relationship with Him.

The exploring of these relationships has also the aim of presenting some parts of the works of 'Abd al-Jabbār, Ibn Sīnā and al-Ghazālī which have not so far been thoroughly examined. Divine assistance, lutf, in 'Abd al-Jabbār's theology is explained in detail in his $M u g h n \bar{\imath}$ Volume 13, but this concept of his has not been thoroughly examined before. 'Abd al-Jabbār shows in his study of divine assistance that God inspires people in order to awaken in 
them the importance of rational inquiry, nazar, which leads them to fulfil their obligations and receive the highest reward, as Chapter 2 shows.

In examining the relationship between God and human beings according to Ibn Sīnā, I shall try to evaluate the importance of his mystical view of God's manifestation of Himself, tajallī, a concept which needs a degree of research not found in many of the writings on Ibn Sīnā. In his works al-Ishārāt wa al-Tanbībāt and Risāla fì al-'ishq, he says that knowledge and love are the two ways of communication between the divine and human; they are dynamically inspired. Chapter 3 will discuss the latter approach by looking at his understanding of the importance of God's manifestation of Himself and the consequence of this manifestation.

Finally, in describing al-Ghazālī's mysticism, the book will focus on his mystical beliefs, which reach their fullness in his concept of fan $\vec{a}$ ' and lead to being able to enter into the divine presence. This study will go on to make a comparison between this concept in Ibyy ' Ulüm al-Din and that of Mishkāt al-Anwār of al-Ghazālī, as will be demonstrated in Chapter 4.

Throughout this study I want to demonstrate three different rational approaches to religion which have some connections and some differences. The differences are seen first in the pursuing of different purposes in approaching a relationship with God. For 'Abd al-Jabbār, mankind was created for the purpose of earning different divine rewards which can only be discovered through human intellectual activity. God assists humans for this purpose and sets up bridges for them. For his part, Ibn Sīnā sees the purpose of the relationship with the divine as lying in the human's capacity to reach the level and enjoyment of the angels (the divine Intellects) in their relationship with God, whereas for al-Ghazāli the importance of the relationship with God lies in reaching an absolute annihilation of oneself which allows the Sufi to see through the eyes of God.

This study will also try to shed light on each writer's process of reaching these different relationships through immediate knowledge and direct communication with God, which unveil their concept of inspiration, ilhām, or intuition, hads. The concept of immediate knowledge is the thread which connects these three scholars and which demonstrates that although all of them emphasize the importance of human rational inquiry yet they also assert the vital importance of a divine knowledge which inspires the humans and moreover provides them with a sense of certainty and tranquillity once they have attained this knowledge. This concept will recur in each chapter and be discussed more fully in Chapter 5, section titled "Their views of human nature and knowledge of God." Finally, the comparison between the ways in which they treat the relationship with God will, it is hoped, be a further contribution to an understanding of their thought.

The purpose of presenting 'Abd al-Jabbār here beside Ibn Sīnā and al-Ghazālī is to assert on the one hand, the similarities and the differences between the theologians, the philosophers and the mystics in approaching the relationship with God. But, on the other hand, what I am trying to do here 
is to demonstrate a side of 'Abd al-Jabbār's theology which has some affinities to both philosophy and mysticism. This side appears in his concept of lutf which shows that God inspires the human mind in all the steps of acquiring knowledge, its start through warnings by means of words sent to the mind, khawațir, or even through suffering and pain in order to provoke certain persons to turn their attention to the importance of knowledge in reaching God. God also provides the first step, which comes through the inspiration of primary immediate knowledge, and finally, God bestows the absolute tranquillity of the soul, sukūn al-nafs, upon certain rational concepts. Thus, God leads humans in their progress of knowledge and unveils His divine assistance, lutf, as will be explained in Chapter 2 .

Although this book does not intend to go extensively into the use of Greek philosophy by these thinkers, its overall purpose is to show that Muslim rational thinkers did not just copy and blindly follow Greek philosophy, but generally made new and valuable contributions to it. While they certainly made great use of Greek philosophy, they were also able to modify and mould the Greek ideas into a totally new system and add their own ideas in presenting an interesting approach to Islam and to the understanding of the relationship between God and humans.

As regards the sources, this work has used mainly primary ones. I have chosen here works which focus on the concept of God, mankind and the relationship between them, and which discuss this in detail. For 'Abd al-Jabbār I make great use of his al-Mughnī fì Abwāb al-Tawhīd wa al-'Adl, Volume 6 with its two parts and Volumes 11,12,13 and 15, which present the most detailed discussion among his works. But I have also used al-Mubīt and Sharh, especially in substitution for the first three missing parts of al-Mughni. In discussing Ibn Sīnā I have mainly used some parts of al-Najāt and Shifäa for his philosophical concepts because they present his full discussion on metaphysics. I have also used intensively the chapter which presents his mystical path in al-Ishārāt wa al-Tanbīhāt, and some of his important treatises such as Risāla fì al-'ishq to examine his concept of the direct relationship with God through His self-manifestation, which he calls tajallī. For al-Ghazālī I mainly used some parts of Volumes 1 and 3 and depended heavily on Volume 4 of Ibyja' 'Ulüm al-Dīn which discusses in detail his mysticism. However, in focussing on the Gnostic side of his mysticism, I have turned to his important work Mishkāt al-Anwār, and I have referred to his Alchemy of Happiness in explaining the nature of the human soul. Other primary sources have also been used when necessary.

Moreover, a number of secondary sources have also been frequently consulted, such as J. R. T. M. Peters' God's Created Speech, which is the best secondary source of understanding 'Abd al-Jabbār, especially in explaining his terminology; G. F. Hourani, Islamic Rationalism, which demonstrates the ethics of 'Abd al-Jabbār's theology and D. Gutas' Avicenna and the Aristotelian Tradition mainly for understanding the chronological arrangement of Ibn Sīnā's works. I have also frequently referred to L. Goodman's Avicenna, which 
presents him in a wider context and discusses and analyses the most important contributions of different scholars who have written about him. I have also made use of the section on Ibn Sīnā in I. R. Netton's Allāh Transcendent; this section describes the influence of al-Fārābī and Greek philosophy on Ibn Sīnā, but distinguishes the parts of his philosophy which we can call Avicennan. I am also indebted to H. Davidson's Alfārābì, Avicenna and Averroes on Intellect for understanding the sources of Ibn Sinnā's theory of intuition. For understanding the problems of inconsistency in al-Ghazālī's mysticism, I have relied on the work of H. Lazarus-Yafeh, Studies in al-Ghazzālī. Besides demonstrating the criteria for accepting the authentic works of al-Ghazālī, Lazarus-Yafeh shows how al-Ghazālī made great use of Neoplatonic concepts in his own terminology and how these concepts influenced his mysticism. For understanding the sources of al-Ghazālî's mysticism, I have found M. Smith's Al-Ghazāli , the Mystic to be of great help.

I have tried, in this book, to present a structure which would narrow the subject in order to be able to create a fair and fruitful comparison between the three different relationships which are discussed in this work. To do so, I have treated the theology of each author in separate chapters, each of which has been split into three main divisions: the first demonstrates the main characteristics of God which are closely connected with His act of communication with humans; the second discusses human nature and the different forms of human knowledge which lead to the knowledge of God and the third concentrates on the relationship between God and humans according to each author. It is often the case that our perceptions of who God is, what His relation to the world is and whether $\mathrm{He}$ is able to know the details of our lives (questions which I shall attempt to answer) form the basis of our understanding of the ways in which He communicates with our world.

Moreover, perceiving the nature of humans and their ability to comprehend the world, along with its Creator, influences the study of the interaction between the human and the divine and what the possible relationships between them might be. Therefore, this methodology explores the understanding of each of these scholars of the nature of God and the nature of humankind and goes on to show how these conceptions influence their understanding of the relationship between the two. However, in following this system, I also wanted to create clear points of comparison for Chapter 5 which aims at evaluating the approach of these by drawing connections and pointing out differences.

This work will, then, be divided into five chapters. Chapter 1 will provide the historical context and Chapters 2, 3 and 4 will introduce the three different approaches to the relationship with God, according to 'Abd al-Jabbār, Ibn Sīnā and al-Ghazālī in turn, leaving Chapter 5 to evaluate and compare their different views.

Chapter 1 aims to provide a contextual study and is divided into three main sections: the first supplies a summary of the historical, political and cultural environment in which the three scholars developed their thoughts. 
The second section provides a detailed bibliography for each of the three thinkers. The third and final section of this chapter attempts to investigate the three concepts: lutf, 'ishq and fan $\vec{a}$ '. The aim of this is to show how these subjects were discussed in different circles around the time in which the three thinkers lived in ways which might have influenced their thought.

Chapter 2 treats the assistance of God through the concept of lutf in the theology of 'Abd al-Jabbār. It consists of three divisions. The first explores the nature of God under three sub-sections: the problem of relating attributes to God, God's essential attributes, understanding God's acts and distinguishing God's gracious acts from His acts of duty. Having introduced the qualities of God in the first section, I then move to consider human nature and knowledge under three headings: the main features of human beings, the importance of rational knowledge in reaching knowledge about God and, finally, the significance of revelation. The third section of the chapter examines the concept of divine assistance, lutf. After explaining the concept of lutf in the first sub-section, a separate sub-section examines God's distinct assistance in the form of sending words to the mind, khawattir, in order to warn of neglecting the importance of rational reflection. The divine assistance, through causing pain and suffering to some in order to prompt them to repent, will be explored in the third sub-section.

Chapter 3 explores the relationship of knowledge and love in the philosophy of Ibn Sīna and is organized in the same fashion as the chapter on 'Abd al-Jabbār. The first section will be divided into three headings, which mainly treat the philosophical description which Ibn Sinnā attributes to God and its consequences. The second examines the two forms of human wisdom, the rational and the revealed. The third explores under three sub-sections man's second way of reaching conjunction with God through the manifestation of Himself, tajallī, from which knowledge and love emanate. My aim here is to connect Ibn Sīnās concept of love and the substantiality of the human soul with his Sufism, as shown in his al-Ishārāt wa al-Tanbīhāt.

Chapter 4 examines the relationship with God through the mystical ascent which leads to self-annihilation, fan $\bar{a}$, according to al-Ghazālī. This chapter is similarly divided into three main sections. The first, as before, explores the nature of God under two headings, the problem of God's attributes and then al-Ghazālî̀s belief in God as the willing creator. In the second, I follow al-Ghazālîs's examination of the concepts of the human soul and human rational and revealed knowledge, each in a separate sub-section. The third explores al-Ghazālīss mysticism: first I introduce the problems arising from the inconsistencies which appear in his mystical writings; then I move to discuss, in a separate sub-section, his mysticism, as shown in his writings in Ibya' 'Ulüm al-Dīn and Mishakāt al-Anwār.

Finally, Chapter 5 is chiefly devoted to comparing and evaluating the three different relationships discussed in the first three chapters. This chapter is divided into two sections, the first demonstrating the differences between the three thinkers and exploring, under different subdivisions, the reasons which 


\section{Introduction}

led to the adoption of different approaches to the relationship between God and humans. The second part provides some evaluations and discusses these writers' common method of acquiring the knowledge of God which rests on the concept of dynamic inspiration.

A note on technical terms and transliteration: this book discusses thinkers who mainly wrote in Arabic, but within different traditions. In the case of Ibn Sinā, I shall use the kind of terminology that is accepted among most scholars familiar with the English expressions which are related to Greek Philosophy. For 'Abd al-Jabbār and al-Ghazālī, who use mostly the language of the Muslim theologians, mutakallimūn, I shall use the terminology translated into English that is almost universal among scholars. Finally, the transliteration of the Arabic words follows the standard form of the British Journal of Middle Eastern Studies. 


\section{Historical and cultural context}

Despite the political instability of the tenth and eleventh centuries AD, these are considered the most important centuries in Islamic culture. During these two centuries philosophy, theology and mysticism developed their most important doctrines. We hear in this period of very famous names, such as al-Fārābī, al-Sijistānī, Ibn 'Adī, Abū Heayyān al-Tawhịīī and Ibn Sīnā in the philosophi-

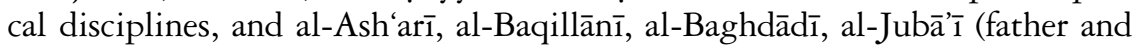
son) and 'Abd al-Jabbār in theological studies. Mysticism too was developed through its masters: al-Junayd, al-Hallāj, al-Bisțāmīe al-Muhāsibīi, al-Qushīrī and al-Ghazālī. However, it was the translation movement of the eighth and ninth centuries which caused the great flowering of Arabic culture in the tenth and eleventh centuries. Most of the important Greek, Indian and Persian works had already been translated by the beginning of the tenth century. These had provided the basis on which the works of many ninth-century scholars, such as al-Kindī, al-Nažāām, Abū al-Hudhayl al-'Alāf and Sahl al-Tustārī, were built. The tenth and eleventh centuries, however, show a concentration and a great leap ahead which was probably due to the particular political and social developments of the time. The true importance of the authors who wrote in these two centuries lies in the originality of their works. This chapter, therefore, will sketch the historical and cultural context of the works to be discussed in this book. It is divided into three sections, giving first a summary of the main political and cultural events of this period and a short description of the problems between the two main religious sects, Shì'a and Sunnī. The first section also describes the system of patronage by the viziers and princes of all the scientific scholars and finally gives some details about the main intellectual circles which influenced the main authors to be discussed in this book. The second section concentrates on the biographies of 'Abd al-Jabbār, Ibn Sīnā and al-Ghazālī and the third section examines the development of the three main concepts to be discussed in this work: lutf (divine assistance), 'ish (divine love) and $\operatorname{fan} \vec{a}$ (annihilation).

\section{Political and cultural development}

The events of the tenth and the eleventh centuries were born out of the decline of the 'Abbasid caliphate at the end of the ninth century. This 
decline began when Caliph al-Mu'tașim, the brother of Caliph al-Ma'mūn (d. AD 833) and son of Hārūn al-Rashīd (d. AD 809) and a Turkish slave, surrounded himself with a vast number of Turkish bodyguards, who had originally been brought into the army in order to counterbalance the large number of Persian soldiers from Khurāsān. The increasing authority of these bodyguards, who were 4,000 in number, caused such fears in Baghdād that al-Mu tașim felt the need to leave the city and therefore built the beautiful town of Samārrā and made it his seat of government. Both al-Mu'tașim (r. AD 833-42) and his son al-Mutawakil (r. AD 847-61) ruled from Samārrā. ${ }^{1}$ After the death of al-Mutawakil in AD 861 the power of the Turkish officers increased so greatly that the caliphs lost all their authority. However, the decisive factor which hastened the decline of the 'Abbasids was the revolt of the Zenj, which lasted from AD 869 to 883 . This revolution against the 'Abbasids was led by slaves who had been transported from East Africa to work underground in the mines of the lower Euphrates - the worst kind of work. After a long and severe struggle to suppress this rebellion, Caliph al-Mu'tadud (AD 892-902) restored Baghdād as his capital and the centre of government. The authority of the army leaders, however, continued to grow, and the caliph's powers gradually shrank, until he controlled mainly religious affairs in his role as the Imām of the state. ${ }^{2}$ A new post was designed, in about AD 930, to give full authority to the holder: the post of Amīr al-Umarā', the chief prince, which was taken by Mu'nis al-Muzaffar. This position took power from the caliph and was a remarkable sign of the renewal of princely authority, with a separation of the different provinces from the central government. ${ }^{3}$ In the west of the empire, the first province to fall away from the hands of the caliphate was Egypt under Ibn Ṭūlūn in AD 868, but the

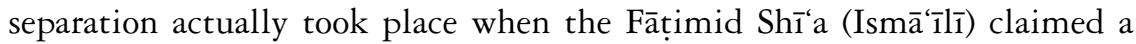
new caliphate in North Africa in AD 909. ${ }^{4}$ This was followed by the declaration of a third caliphate, in AD 929, by the Umayyad ruler 'Abd al-Rahman III in Spain. ${ }^{5}$ In eastern Persia, the Țāharids and the Șaffārids ruled independently as early as AD 820, and finally, the Buyids, who had been ruling the western Persian provinces, took over Baghdād and ruled as the chief princes from AD 945-1055. ${ }^{6}$

Thus, the most important political feature of the tenth and eleventh centuries is the rise of independent kingdoms, which started first in the western regions of the Islamic empire and prompted similar developments in the east, as will be described later. Although this development was the beginning of the end of the 'Abbasid dynasty, it marks the start of a strong Islamic culture which flourished under the different separated dynasties: in Spain, Qurțuba became one of the important cultural centres under the Umayyad caliphs, while Cairo also became a famous centre of learning under the Fāțimid. In the east, Khurāsān, al-Rayy and Shirāz were known for their excellent libraries and famous medical centres under the Sāmānids and Buyids; Nīshāpūr also became a centre for the Sunnī under the Saljūq sultans. 


\section{Early political developments in Persia}

'Abd al-Jabbār, Ibn Sīnā and al-Ghazālī are three Persian thinkers who lived in different towns in Persia on the east of the 'Abbasid Empire during the reign of the Buyid princes and early Saljūq sultans. This region of the "Abbasid Empire had been given to Țāhir Ibn al-Husayn by al-Ma'mūn (d. AD 833), the great 'Abbasid caliph and son of Hārūn al-Rashīd, as a reward for his victory over the army of al-Aminn, the former caliph and a brother of al-Ma'mūn (who ruled from AD 809 to 813). Tāanir placed the centre of his power in Khurāsān. He established an independent province which extended as far as the borders of India. In the year AD 892 the Sāmānid Ismāâl Ibn Ahmad established a new dynasty in Khurāsān. Ismāīil was a grandson of Sāmān, a Zoroastrian noble from Balkh. This Sāmānid dynasty remained in power over the east of Persia until AD 999.7

If we turn now to the Buyid dynasty, which ruled the western territories of Persia and for some time (AD 945-1055) Baghdād also, we find that they probably descended from a noble Daylamite family, as they claimed, and were descendants of Abū Shujā' Ibn Buhyah or Buyid. The Daylamites lived in the district which extended from Jīlān, Jurjān to Ṭabaristān; they never accepted other authorities and were known even not to have adopted any religious traditions until the arrival of the Shī'at Zaydī missionaries. It was Yehịa Ibn 'Abdullah al-Hasani who reached there in about AD 791; he succeeded in spreading Zaydī Shī' ism among the tribes of the mountain dwellers from Jīlān to Tabaristān. But it was al-Hasan Ibn Zayd who established a Zaydī dynasty in Tabaristān from AD 864 to $914 .{ }^{8}$ After the death of the last Zaydī ruler, al-Hasan Ibn al-Atrrush, in AD 917, some of the Daylamite leaders imposed control on the Zaydī region and ruled in their own names. Muradwidge Ibn Zyār fought against all other Daylamī leaders and established the rule of the Zyārīs in Țabaristān. The two Daylamite brothers 'Alī and Hasan Ibn Shujā' Ibn Buyid became known for their power and courage in the army of the Daylamite leader Makān Ibn Kakī, who finally lost his leadership and retired with his army. The two brothers were allowed to join the army of Muradwidge and soon became known for their courage. ${ }^{9}$ After the death of Muradwidge in AD 934, 'Alī and Hasan, with their younger brother Ahmad Ibn Buyid, led an army which consisted of Daylamite and Turkish soldiers and extended their rule over Fars, Kirmān, Tabaristān, Rayy and Iṣfahān to the border of the Sāmānid territories of Khurāsān. In AD 955 they signed a peace treaty with the Sāmānids which gave them legitimacy to rule the districts they had conquered, so long as they paid the Sāmānids a tribute. ${ }^{10}$

In Baghdād, as mentioned above, the central government had declined and the caliphs had lost their authority as political leaders and were recognized only as head of the imamms, the religious public leaders. And although the 'Abbasid caliphs in the first 'Abbasid era did not make much use of the position of vizier, the caliphs of the second era had to accept the new office of Amir al-Umār', chief of princes, in order for a weak central government to escape the burden of administration and, in the case of the caliph 
al Rādī (r. AD 934-40), to escape from economic crises. ${ }^{11}$ The replacement of many caliphs by the chief princes hastened the 'Abbasid decline and presented the opportunity to the Buyid ruler of Kirmān, Ahmad Ibn Buyid, to attack Baghdād and establish the Buyid dynasty there in AD 945. The Buyids were given the post of Amīr al-Umarā' and were recognized as the actual rulers of Baghdād. As soon as Ahmad Ibn Buyid became chief of princes and received the title Mu'iz al-Dawla for himself and the titles Rukn al-Dawla and 'Imād al-Dawla for his brothers Hasan and 'Alī, respectively, he replaced the caliph al-Mustakfī by his cousin al-Muțī. The Buyid dynasty remained in Baghdād for about 110 years. ${ }^{12}$

However, Mu'iz al-Dawla did not attempt to unify the Islamic empire under his family's leadership nor to spread his power beyond Baghdād and Kirmān. Nevertheless, he considered himself the official head of the 'Abbasid government and forced the heads of other provinces, such as the Hamadānids in Mousel, the province of Bațina and the Arab tribes living in the south of Iraq, to pay him a tax for their being allowed to remain in power. ${ }^{13}$

The Buyids were not experienced in administering such a vast region with different provinces and therefore they needed the advice of good and experienced viziers. The first advice was to keep the office of the 'Abbasid caliph because, on the one hand, it had great religious significance for the public and, on the other hand, as adherents of Shī ism, the Buyids could not rule the Sunn̄̄ majority of Baghdād. However, they restricted the authority of the Sunnī caliph to religious affairs. ${ }^{14}$ The second problem which Mu'iz al-Dawla faced was the need to increase his military forces in order to be able to control Iraq and Fars; soon he could not afford to pay his soldiers' wages. He was advised to revise the tax system of the $i q t \bar{a}^{6}$, the land given as reward for service of military leaders, and the land owned by the caliph and the princes. ${ }^{15}$

Al-Mu'iz had then established the Buyid administration system, which was followed during the whole Buyid rule. The Buyid domain was divided into three districts: the area from al-Rayy to Jibāl was governed by Rukn al-Dawla, Fars was ruled by 'Imād al-Dawla and the southern part of Kirmān and Khuzistān was under the governance of Mu'iz al-Dawla. After Mu'iz al-Dawla's death, his son Bakhtyār became the new Amīr al-Umarā' and followed his father's system of making the rulers of the different provinces in Iraq pay certain taxes to stay in power. In his first years, he had to establish his authority over the Hamadānids of Mouṣel and later to fight 'Umar Ibn Shāhīn, the ruler of al-Bațịha. At the same time, he faced an uprising in his own military forces led by a Turkish officer, Sebkatakin, which caused conflict in Baghdād. The Shī'at population supported Bakhtyār, and the Sunnīs gave their support to Sebkatakin. Bakhtyār asked the help of his cousin 'Aḍud al-Dawla, the ruler of Fars, after the death of his uncle 'Imād al-Dawla, but the latter seized the chance of winning Baghdād for himself. 'Aḍud al-Dawla's father, Rukn al-Dawla, denounced this attack on Bakhtyār and ordered his son to withdraw from Baghdād. However, after the death of Rukn al-Dawla, 'Adud al-Dawla once more attacked Baghdād and ended the regime of Bakhtyār. ${ }^{16}$ Mū'ayȳ̄d 
al-Dawla and Fakhr al-Dawla, the two brothers of 'Aḍd al-Dawla, ruled respectively over Rayy and Ișfahān. ${ }^{17}$

'Aḍud al-Dawla is considered the greatest Buyid ruler; he was a politician with a mind of his own who could rule without depending on his vizier, unlike the other Buyid rulers. He had a vision of establishing a Buyid empire united under one ruler. J. L. Kraemer divides the Buyid age into three epochs: the early period (AD 945-77), the period of the empire (AD 977-1012) and the period of decline and fall (AD 1012-55). The empire was established under 'Aḍud al-Dawla and continued by his three sons, Șamṣām al-Dawla (AD 983-7) Sharaf al-Dawla (AD 987-9) and Bahā' al-Dawla (AD 989-1012), but it did not endure. ${ }^{18}$ After the relatively long rule of Bahā' al-Dawla, the Buyid princes became less competent and lost their authority as chief princes.

After this period of 110 years the Buyids lost power, first in the Persian provinces and finally in Baghdād, from which they were expelled by the Saljūq Sultan Tughrīl Begh in AD 1055. However, the Buyids had already lost most of their provinces to the Sunnī Turkish Ghaznawid Sultan Muhmoud (r. AD 999-1030), who gradually conquered most Buyid territories. ${ }^{19}$ The Ghaznawid were Turkish slaves in the Sāmānid army; among them was Alptigin, who was promoted to head of the guards and soon became the governor of Khurāsān. After losing favour among the Sāmānids, he occupied Ghaznah and with his son-in-law Subuktigin established a Ghaznawid kingdom (AD 962-1186). Sixteen Ghaznawid rulers succeeded them, the greatest of whom was Sultan Mahmoud (r. AD 999-1030). The Ghaznawids were Sunn̄̄ Turkish, who were eager to get rid of their Shīat Buyid neighbour. Sultan Mahmoud led many campaigns against the rulers of Rayy and Ișfahān and was rewarded by the 'Abbasid caliph with the title of Yamīn al-Dawla (the right hand of the state). ${ }^{20}$

However, it was the Sunnī Saljūq sultans who finally brought to an end the Buyid dynasty; they fought against the Buyids and entered Baghdād in AD 1055. The Saljūqs were a tribe of Turkish nomadic people who were allowed to settle in Būkhārā with their chief leader, Saljūq, in AD 956, where they also embraced Sunn̄̄ Islam. A grandson of Saljūq, Tughrīl, was able with his brother to reach Khusārān in AD 1037 and occupy Marw and Nīshāpūr, from which they soon penetrated Rayy and Ișfahān. The 'Abbasid caliphs welcomed these Saljūq campaigns as a way of getting rid of the Buyid Shī'at rule and prepared a way for them to enter Baghdād. Tughrīl began to rule in Baghdād (AD 1055-63) and was followed by his nephew Alb Arsalān (r. AD 1063-72). Alb Arsalān, with his remarkable vizier Niz̄ām al-Mulk, not only provided peace among the different provinces but also led the march against the Byzantines which signalled the end of Buyid rule. In AD 1071, he won the battle of Manzikart in Armenia and captured the emperor Romanus Diogenes but freed him after signing a peace treaty in favour of the Saljūqs. Alb Arsalān and his son Malikshāh (r. AD 1072-92) did not use Baghdād as the seat of government but, under the guidance of the wise Nizām al-Mulk, ruled from Rayy and Iṣfahān and from Nīshāpūr in Khurāsān. Another son of 
Alb Arsalān, Tutush, became the governor of Syria (r. AD 1094-1117); he stopped the advance of the crusaders in Alleppo and also stood against the Fātimid power in Syria. The later Saljūqs transferred their administrative centre to Baghdād and remained in power until AD $1194 .^{21}$

\section{Main religious groups}

In the tenth and eleventh centuries, Shī'a and Sunnī Islam took clear shape and were equally important in the 'Abbasid Empire. Shī' ism flourished most successfully then; at the beginning of the tenth century it was established in an empire in North Africa (under Ismā̄îlì Fāțimid) and had strong adherents in most of the provinces of west Persia and in Bahrayn. Most of the Muslims in Baghdād were Sunn̄̄ and, moreover, in the tenth century Mu'tazilite theology, which is sympathetic to Shí'ism, was no longer as popular as it had been at the time of al-Ma'mūn. Later caliphs, especially al-Mutawakil, favoured Hanbalite and Ash'arite theology. This section will provide brief definitions of Shīa and Sunnī Islam and sketch their development during this period.

The Shi' $\bar{i}^{\prime}$ The most important division of the Shi's a come under the three sects: Imāmiyya, Zaydiyya and Ismāîliyya. The Imāmiyya, which later formed the Ithnā 'Ashrīyya, did not accept the imamate of the first three caliphs, Abū Bakr, 'Umar and 'Uthmān, but were moderate and accepted Sunnīs as their rulers. The Imāmiyya separated from the Zaydiyya when some Shī'as did not accept the imamate of Zayd Ibn 'Alī Ibn al-Husayn and declared his brother Muhammad al-Bāqir to be the fifth Imam. This was because Zayd rejected the condemnation of the first three caliphs and considered Sunnī Muslims as believers, but, in contrast to the Imāmiyya, considered the ruling authorities their immediate enemies. However, since the disappearance of the last Imam of the Ithnā 'Ashriyya Imāmiyya, Muhammad al-Mahdī (al-Qā'im), whose return was still awaited, the Imāmiyya did not have a visible Imam who would be competent to act as caliph and consequently developed good relationships with the Sunnī rulers. ${ }^{22}$ The Imāmiyya spread in Baghdād and were protected by the Buyids for their moderate attitude towards the Sunnī majority. ${ }^{23}$

The Zaydiyya, in contrast, (followers of the fifth Imam Zayd Ibn 'Alī Ibn al-Husayn) accepted Imams who were deeply learned in the religious sciences and intellectual knowledge, but not necessarily from the Prophet's family. Unlike the Imāmiyya, the Zaydīs had visible imams who were competent to take authority as caliphs and therefore had to flee to the mountains by the Caspian sea in the Daylamite region (and Yemen). The Zaydī Shī'a missionaries were able to spread Zaydiyya among the inhabitants of this area and establish a Zaydī dynasty in Tabaristān. Zaydīs in general, although they have a militant call to oppose Sunn̄̄ rulers and 'Abbasid caliphs, tend towards a rational dialectic theology and are supportive of Mu'tazilite views. ${ }^{24}$ Hamadhān, Rayy and Ișfahān welcomed Mu'tazilite circles during the Buyid regime. The Būhāshimiyya school of Baghdād, followers of Abū Hāshim 
al-Jubā' $\overline{1}$, who moved from Baṣra to Baghdād, sent the scholar 'Abd al-Jabbār Ibn Ahmad to Rayy in order to establish a Mu'tazilite branch there. A faithful student of 'Abd al-Jabbar, Manqadīm was a Zaydī Shī'̄i who compiled his lectures in the book known as 'Sharb al-'Ușul al-Khamsa', but, against his master's wishes, wrote on the Zaydi imamate at the end of the book. ${ }^{25}$

The Ismā'îlì Shī'a are those who accept the seven Imams, the last of whom was Ismā‘̄̄l Ibn Ja'far al-Șādiq. There are different groups of Ismā‘n̄ili of different degrees of moderation; however, all of them believe in the two levels of Islam, the esoteric and exoteric, al-Bātin wa al-Zāhir. Al-Zāhir is the external message of Islam, which is directed to the masses in order to communicate direct straightforward beliefs, while al-Bätin is the esoteric science which leads to the truth and is only revealed to a few Imams and Da'̄is. Ismā‘̄iliyya spread in al-Kūfa under Hamdān Qarāmat about $\mathrm{AD}$ 877, but finally an Ismā‘̄îlī Qarāmitī state was set up in Bahrayn. The largest Ismā'ầlī group, however, was the Fātimids who governed north Africa and established a caliphate in Cairo in $\mathrm{AD}$ 920. An Ismā'īlī extremist group moved to the region of the Daylamite mountains under the leadership of the Persian al-Hasan i-Ṣabbāh. Hasan formed secret groups which hid in remote castles and mounted militant attacks against the Sunnī Saljūqs from AD $1090 .^{26}$ They probably killed the vizier Niẓām al-Mulk and threatened al-Ghazālī because of his famous book

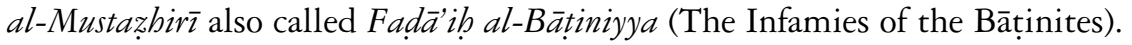

The Sunnī Islam These were first known as the group of Ahl al-Jamā'a wa al-Sunna, probably established by Ahmmad Ibn Hanbal (d. AD 855) in Baghdād. This group had put great emphasis on the importance of the Qur'ān and Hadīth as the only sources of Islam. They rejected any interpretation of the Qur'ān except by the Hadīth and denounced the concept of the temporal nature of the Qur'ān which was preached at the time of the caliph al-Ma'mūn. Al-Ash'arī (d. AD 950) adopted their main theories but with great modifications, introducing a more intellectual system which became later known as Ash'arī Sunnī Islam. Perhaps the main feature of the Sunnīs of Baghdād in the tenth century was the increase in the number of the Hanbalite-oriented scholars and students who were able to convert great numbers of the uneducated citizens of Baghdād. By the time of the Buyid invasion, the Hanbalite had become the majority group and were threatening the Shī'is of Baghdād and other Sunn̄̄ groups such as the early Ash'arites. ${ }^{27}$ The Buyid to some extent were obliged to show tolerance in order to bring peace to Baghdād. They were advised by their viziers to provide freedom for religious organizations to form and practise their beliefs. However, in the time of Bahā' al-Dawla, a son of 'Aḍud al-Dawla, the caliph al-Qādir (r. 991-1031) supported Hanbalism and took serious steps against the Imāmī Shī'a of Baghdād. ${ }^{28}$ In the east, in contrast, Sunnīsm under the Sāmānids was moderate and relatively tolerant of the Shī'i minorities; this can be seen from the appointment of Ibn Sīnā's father, an Ismā‘ $1 \overline{1} \overline{1}$, to the position of governor of Kharmmithan, a village near Būkhārā, and the permission given to Ibn Sīnā to visit the Royal library and to become the physician of Prince Nūh Ibn Manșūr al-Sāmān̄i in AD 997. ${ }^{29}$ The situation, however, changed radically 
when the Sunnī Turkish Ghaznawids and the Saljūqs came to power at the beginning of the eleventh century. They systematically attacked all Shī'a states and set up schools to counter Shì at thought at all levels. The Saljūqs were mostly Shāf ìs and therefore built their Niz̧āmiyya schools in Nīshāpūr and in Baghdād in order to suppress the fanaticism of the Hanbalites and the Shī' a. ${ }^{30}$

\section{The patrons of culture in the tenth and eleventh centuries}

The 'Abbasid caliphate court was famous for its support to all kinds of cultural disciplines from astronomy, the natural sciences, philosophy and kaläm theology to poetry and the linguistic sciences. Caliphs and their viziers supported many famous thinkers and were the main patrons of all cultural activities. Baghdād, as the seat of the caliph, became the main cultural centre where most intellectual activities took place. Caliphs themselves were cultured men who were famous for mastering literary disciplines such as poetry. Viziers had always played an important cultural role; Yahya the Barmakide, the vizier of Hārūn al-Rashīd, for example, was famous for his salon, majlis. One of the important sessions of this majlis was the famous discussion on the different senses of "love," at which Abū al-Hudhayl al-'Alāf and Hishām Ibn al-Hakam were present. ${ }^{31}$

In the Buyid period, the cultural role of the viziers became very important; the first Buyids, the three brothers had little cultural background themselves and were therefore wholly dependent on their viziers. Mu'iz al-Dawla was untutored and knew little Arabic, but his sons were active in cultural pursuits and were skilled in the Arabic language and poetry. Bakhtyār was a celebrated poet and patron of Arabic literature. His brother al-Habashī, the governor of Bașra, was a highly cultured prince who collected a library with 50,000 works and was interested in Mu'tazilite theology. ${ }^{32}$ Moreover, the two princes, Shams al-Dawla, the son of Fakhr al-Dawla, who ruled in Hamadhān, and prince 'Alā' al-Dawla, who ruled in Ișfahān, were learned men and supporters of learning and philosophy. The two of them were the patrons of Ibn Sinnā.

The Buyid viziers were not only active patrons of many thinkers of the time but also significant scholars themselves. Mu'iz al-Dawla's vizier, Abū Muhammad al-Muhallabī, was active culturally and led an important group which met twice a week. In his circle many significant theologians, grammarians, poets and judges took part, such as the famous poet Ibn al-Hajjāj and Abū al-Farāj al-Ișfahānī, the author of Kitāb al-Aghānn̄. ${ }^{33}$ Ibn Sa dān, another Buyid vizier in Baghdād, was the patron of many members of the school or circle of al-Fārābī and Ibn 'Adī.

Another important Buyid vizier from the Persian provinces is Abū al-Faḍl al-'Amīd. He was the vizier of the son of Rukn al-Dawla, prince Mü'ayyd al-Dawla, the governor of Rayy. Al-'Amīd was an important philosopher and patron of many philosophers from Rayy and Khurāsān. Also al-Ṣahịib Ibn 'Abbād, the vizier of Rayy after al-'Amīd, was a Mu'tazilite theologian and the patron of 'Abd al-Jabbār. ${ }^{34}$ 
The patronage of scholastic learning by the viziers remained an important feature of the late 'Abbasid period and was adopted also by the Saljūq sultans after the Buyids. Although the Saljūq viziers and princes continued to be patrons of the sciences, Nizām al-Mulk and other viziers of the Saljūqs were zealous in spreading Sunnīsm and abolishing Shī'a institutions. The famous Dār al-'Ilm, a Shī'i academy with 100,000 manuscripts, was destroyed by Tughrīl Begh when he came to Baghdād. The most prominent vizier of this late period is the famous Niẓām al-Mulk. He was a Persian Shāfi from Khurāsān and became the vizier of Alb Arsalān, but in the reign of Malikshāh he became the most important authority in the Saljūq empire. He built several schools, the most important of which are the Nizāmiyya schools in Nīshāpūr and in Baghdād. Nižām al-Mulk was the patron of al-Ghazālī; he first employed him in the Nizāmiyya of Nīshāpūr and then sent him to direct the school of Baghdād. ${ }^{35}$ Thus, the cultural activities of princes and viziers of the tenth and eleventh centuries were a decisive element in developing the Arabic and Muslim civilization of this period.

Students of this period travelled to join those famous scholars who were also wandering from court to court seeking the patronage of princes and viziers. Since in the Buyid period there were no such things as schools, in the sense of places where there was a system of learning and different teachers whose students studied a certain curriculum, learning was restricted to certain circles, famous for one or more well-known masters. These circles were wholly dependent on the financial support of important and wealthy persons or officials. This probably meant that most scholars had to adopt certain political positions and had to compromise with their own beliefs and convictions. The dedication of scholarly works to princes and viziers was a common form of publication; sometimes limited copies were made for others. ${ }^{36}$ There were many places of learning: religious sciences were usually studied in the mosque; other disciplines - natural science, philosophy and theology - were taught at the teacher's home or in the market-place or in public gardens. ${ }^{37}$ The first organized schools, madrasa, probably date from the Saljūq period under the influence of the Nizāmiyya schools. ${ }^{38}$

\section{Intellectual circles}

Despite the Sunnī-Shi'i conflict of this period, other groups and intellectual circles were active and productive. Academic and intellectual circles were generally connected to certain scholars who formed their own entourage for regular meetings. Centres of learning such as Baghdād, Shirāz, Rayy, Ișfahān, Cairo and Qurțuba were famous for their different intellectual circles; our interest here, however, will be concentrated on the eastern part of the empire. Several academic and intellectual groups were founded in the Buyid reign and supported by the viziers and princes of the time, not only in the Buyid territories but also in the Sāmānid provinces. The most important groups for our purposes here are as follows: the Būhāshimiyya school of Bașra and its 
connection to Rayy, the school which influenced the thinking of 'Abd al-Jabbār; the philosophical (school) of Khurāsān, which Ibn Sīnā probably encountered in his early education in Būkhārā and, finally, the Shāf'ì school of Nīshāpūr where al-Ghazālī received his mature education.

An important intellectual group for our study here is the Mu'tazilite school of Būhāshimiyya in Bașra and Baghdād. This school was established mainly by Abū Hāshim al-Jubā'̄ (d. AD 933) after the death of his father Abū 'Alī al-Jubā'̄ in $\mathrm{AD}$ 915. Its problems started when some of the Mu'tazilite Bașrī school refused to consider Abū Hāshim as the successor of Abū 'Alī because of his opinion on certain questions which differed from that of his father's. This conflict divided the Bașrī school into the Būhāshimiyya, the followers of Abū Hāshim, and the Akhshīdiyya, the followers of Abū 'Alī. The Akhshīdiyya were led by Abū 'Abdullah Muhammad al-Saymarī (d. AD 927) and later by Abū Bakr Ahmad Ibn 'Alī al-Akhshīd (d. AD 938). The main objects of dispute between the Akhshīdiyya and the Būhāshimīyya seem to concern Abū Hāshim's famous theory of "states" (abwāl) and some other doctrinal questions, according to 'Abd al-Karim 'Uthman in his book al-Khiläf bayn al-Skaykhayn. ${ }^{39}$ Abū 'Abdullah al-Bașrī (d. probably in AD 979) and Abū 'Alī Ibn Khallād, two students and sincere followers of Abū Hāshim, were considered to be the actual founders of the Būhāshimiyya school in Baghdād. According to Ibn al-Murtadāa, Abū 'Abdullah al-Bașrī was the teacher of 'Abd al-Jabbār, who transmitted to him the Mu'tazilite doctrines. 'Abd al-Jabbār, however, was sent to Rayy to establish a Mu'tazilite school there at the invitation of the vizier of Rayy, al-Șāhib Ibn 'Abbād. Al-Ṣahib was the vizier of Mū'ayyd al-Dawla the son of Rukn al-Dawla and later on the vizier of his brother Fakhr al-Dawla. ${ }^{40}$ Al-Ṣāhib Ibn 'Abbād (d. AD 995) was himself a very learned Mu'tazilite theologian who admired 'Abd al-Jabbār and therefore appointed him as the chief judge of Rayy. He adopted the Hanafi views in jurisprudence and defended all the Mu'tazilite concepts; it is also reported that he formed a missionary group of adherents to Mu'tazilism who were called du'ât or khușsat al-Ṣāhib, the missionaries or elite of al-Ṣahhib. This group's task was to spread the Mu'tazilite theology among the masses. Kraemer presents numerous reports, mainly from al-Tawhīīi, which describe and evaluate al-Ṣāhib’s personality. Tawhīin̄ seems to have disliked or even despised al-Ṣāhib: he reports that many scholars considered him to be dishonest and suspect in his religious beliefs, even though he adopted Mu'tazilism. ${ }^{41}$ It seems also that he discouraged the learning of philosophy and its branches and considered it a heresy. Nevertheless, he was a patron of many scholars and theologians and won the admiration of both Prince Mū'ayyd al-Dawla and Prince Fakhr al-Dawla. Thus, Rayy under the influence of the two viziers, Ibn al-'Amīd, who favoured the learning of philosophy with all its branches especially its scientific side, and al-Ṣạhib, who supported and encouraged Mu'tazilite theology, became a cultural centre for many intellectuals.

Another important intellectual circle of this period in the Sāmānid territories consisted of the philosophers of Khurāsān. The information about this group of philosophers is somewhat limited, but one source is Ibn Sīnā's book 
al-Inșâf (Fair Judgements), in which he describes a conflict between the eastern and western philosophers of his time: "and I had the Easterners argue against the Westerners until I intervened to judge fairly when there was a real point of dispute between them." ${ }^{2} 2$ Suhrawardī believes that the eastern philosophers were the group of philosophers in Khurāsān, and perhaps the western ones were the philosophers of Baghdād, as Pines maintains. ${ }^{43}$ We are familiar in Baghdād with the philosophical school of al-Fārābī, which tended to follow the Greek philosophers without any great changes, mainly commenting on and clarifying their main concepts. The Khurāsān school were probably followers of al-Kindī, especially in his belief that revelation in its content goes beyond philosophy and is able to explain concepts which are not logically conceivable, such as creation ex nibilo and the resurrection of bodies. The founder of this school seems to have been Abū Zayd al-Balkhī, who was born in Balkh in Khurāsān in AD 850 and died there in AD 934. He studied for eight years in Baghdād under the philosopher and scientist al-Kindī. ${ }^{44}$ About this time the Sāmānid prince Nașr Ibn Ahmad was converted to Isma'îlissm under the influence of the Ismā'îlī philosopher al-Nasfaī; and since al-Balkhī was a Shī'ī Zaydī he was invited to teach in Būkhārā. After returning to his homeland, al-Balkhī seems to have established a group for studying philosophy and its connections with Islamic dogmas. One of his important students in Būkhārā was the famous philosopher al-'Āmirī (d. AD 992). Following the steps of his masters, al- 'Âmirî̀s main concern in most of his books was to reconcile philosophy and Islamic dogmas, attempting in his work On the Afterlife to find a common thread linking the five most important Greek philosophers - Empedocles, Pythagoras, Socrates, Plato and Aristotle - with the prophetic tradition. To this group of philosophers belong also Abū Tammām al-Nīshāpūrî́ ${ }^{-15}$ and probably also the vizier Ibn al-'Amīd, the patron and teacher of al-'Āmiri in the five years which he spent in Rayy. ${ }^{46}$ Interestingly, al-Jarīīi (or al-Harīî̄i) in his debate against Abū Sulaymān al-Maqdisīi, an important member of Ikhwān al-Ṣafā', considers the Ikhwān to have been greatly influenced by the philosophers of Khurāsān, especially al-Balkhī and al-'Āmirī. He draws many links between their methods, thus suggesting the possibility that some members of the Ikhwān existed in the region of Khūrāsān. This debate was fully reported by Abū Hayyān al-Tawhīdī (d. AD 981) in his al-Imtā' wa al-M $u^{\prime}$ anasa. ${ }^{47}$ Thus, this group of philosophers of Khurāsān may also have included some members of Ikhwān al-Ṣafā' and were spread between Būkhārā and Nīshāpūr, the region where Ibn Sīnā and al-Ghazālī spent their childhood and early youth. In his autobiography, Ibn Sinnā, however, does not mention the influence of this group on his philosophical education, although it is nearly certain that he was influenced by some of the Ikhwān's treatises, as we will show below. Two reasons could have made Ibn Sinna silent about his early relationship with this group: first is the suspected religious tendency of their philosophy, which was a reason for the conflict between them and the philosophers of Baghdād, as al-Tawhīiñ reports. ${ }^{48} \mathrm{Abu}$ Sulaymān al-Sijistānī, for example, severely criticized the doctrines of the 
Ikhwān ${ }^{49}$ and al-'Āmirī mentions the lack of hospitality shown to him by the Baghdādī philosophers. ${ }^{50}$ The second reason, however, was probably Ibn Sīnā’s rejection of the doctrines of creation ex nibilo and the resurrection of bodies, the two most important concepts of this group. However, Ibn Sinnās notion of relating the existence of every being directly to God in his theory of "essence and existence" (as will be explained in the chapter on Ibn Sīnā) and the mystical tendency of his late philosophy could reflect the influence of the Khurāsān philosophers.

The third learned circle in this region is the Nizmanmiyya school of Nīshāpūr. In order to suppress the learning of Shî̀'ism, several Shāf'ì academic schools were built in some of the important centres of the empire, such as Nīshāpūr and Baghdād. These schools, which were named Nizāāmiyya, are considered the first actual academic centres of learning in the region. The Nizāmiyya of Nīshāpūr was famous for its theologians, such as al-Juwāynī and al-Ghazāâin. Al-Juwāynī seems to have been the first leader and director of the school who promoted the academic learning not only of jurisprudence but also rational kalām theology and even philosophy. Smith shows that in the Nizāmiyya under al-Juwāynī’s leadership the curriculum of learning included philosophy and Sufism. ${ }^{51}$ Probably the kind of philosophy which alJuwāynī supported was that preached by the philosophers of Khurāsān. By the time of al-Ghazālī, the Nizāamiyya of Nīshāpūr was facing an attack on its system of learning from the growing Ismā'îlī group known as Ta'līmiyya Bătinīyya. This led al-Ghazālī to compose his famous book Fadă' al-Bāttiniyya. The situation of the Nizāmiyya in Baghdād, however, seems to have been quite different. The Shāf ${ }^{i} \bar{i}$ school was in conflict not only with Shi' ${ }^{-1}$ ism but also with the Hanabalite theology which had taken deep root in Baghdād. They also had to face the highly intellectual school of philosophy there. Furthermore, the Mu'tazilite school feared losing many of its students to the new academic Nizāmiyya Shāf' $\overline{1}$ school and probably spread suspicion about its academic competence. This is likely to have challenged al-Ghazālī to compose his two works Maqāsid and Tahāfut la-Falāsifa in Baghdād.

After the above outline of the political and cultural environment during the period of 'Abd al-Jabbār, Ibn Sīnā and al-Ghazālī, the next section will give some details of their lives.

\section{The life and works of 'Abd al-Jabbār, Ibn Sīnā and al-Ghazālī}

\section{'Abd al-Jabbār}

Trustworthy biographical details of the life of 'Abd al-Jabbār are difficult to ascertain; his full name was probably Abū al-Hasan 'Abd al-Jabbār Ibn Ahmad al-Hamadhāni. ${ }^{52}$ The year of his birth is most likely to have been AD 932 in Asadabād near Hamadhān. It is possible that he came from a poor family, which caused him to stay in Asadabād for his early education. According to 
Tabaqāt al-Mu'tazila, he started his theological studies in Ișfān under the Ash'arite school; however, this report may be doubted since the Ash'arite theology, which started in Bașra in AD 913, must have been in its very early stages and is unlikely to have reached this region by that time. He most probably received a traditional Shāf ite education, as Madelung maintains. ${ }^{53}$ He probably travelled to several towns in search of better teaching; it is known that he was in Hamadhān and Ișfhān before travelling to Bașra. At about AD 957 he travelled to Bașra to collect Hadīth; however, he was soon impressed by the Mu'tazilite teaching and studied their sciences under the famous theologian Abū Ishāq Ibn 'Ayyāsh (d. AD 970). He left for Baghdād perhaps between the years $\mathrm{AD} 957$ and 970 to study under the famous Mu'tazilite theologian Abū 'Abdullah al-Bașrī (d. AD 977). Abū Abdullah was the leader of the Būhāshimiyya Mu'tazilite school of Baghdād. 'Abd al-Jabbār became a follower of Abū Hāshim al-Jubā̄̄'s theology, as he demonstrates in his encyclopaedic work al-Mughnī. ${ }^{54}$ This period seems to have been very productive since he composed and compiled many works, some of which are Naqd al-Luma', a refutation of al-Ash'arī's Kitāb al-Luma'; Kitāb al-'Umad on legal theories; Taqrīb al-Ușül; Tahdhīb al-Sharb; Kitāb al-Mabsüt; Sharh al-Jāmi al-Saghīr, a commentary on Abū Hāshim's book al-Jāmi' al-Saghīr and Kitāb al-Nihāya, on legal theories. ${ }^{55}$

The next destination in 'Abd al-Jabbār's journey was the province of Khuzistān in about AD 968 or 970 . There, Mu'tazilism had deep roots, since Abū 'Alī al-Jubā'̄ and his son Abū Hāshim had lived and taught in 'Askar Mukaram, one of its towns. 'Abd al-Jabbār also taught in this town and in Rāmhurmuz, where he probably also started to dictate his famous work al-Mughnī. ${ }^{56}$

The turning point of 'Abd al-Jabbār's career was when the famous al-Ṣāhib Ibn 'Abbād, the vizier of Prince Mū'ayyd al-Dawla and Prince Fakhr al-Dawla, the two brothers of 'Aḍud al-Dawla, was looking for a new chief judge for al-Rayy. Since al-Șāhib was a learned Mu'tazilite he asked the advice of Abū 'Abdullah al-Bașrī, who first suggested Abū Ishāq al-Nașībīnī. However, al-Ṣahịib did not like al-Nașībīn̄i and asked for someone else, whereupon Abū 'Abdullah sent him 'Abd al-Jabbār. 'Abd al-Jabbār was appointed chief judge of Rayy sometime between AD 972 and 977 . He remained in this office until the death of al-Șăhib in AD 995. During this time he also completed the dictation of al-Mughnī (AD 990) which means that he may have spent about twenty years compiling it. ${ }^{57}$ However, at the end of the work, 'Abd al-Jabbār mentions some other books which he also dictated in the same period.

These are as follows:

1 Sharb al-Ușül al-Khamsa, a work that is probably a commentary on an earlier work of his titled Kitāb al-Ușul al-Khamsa. Kitāb al-Ușūl was found among the manuscripts of the Vatican collection;

2 Sharḅ al-Maqālāt, a commentary on al-Maqālāt a work written by Abū al-Qāsim al-Balkhī; 
3 Bayān al-Mutashābih fì al-Qur'àn, an explanation of some difficult passage in the Qur'ān;

4 Kitāb al-I'timād;

5 Sharḅ al-Jawāmi', probably a commentary on Abū Hāshim's book al-Jāmi' al-Kabìr;

6 Kitāb al-Tajrīd;

7 Sharb Kashf al-A'rād;

8 Sharb Adab al-Jadal, which is a commentary on a book called Adab al-Jadal, (The Rules of Disputation), which could be a refutation of a book of this title by Ibn al-Rawāndīi. ${ }^{58}$

In this period some answers to questions which had been put to him were compiled in many books named after the towns where he gave those answers, as is reported by Ibn al-Murtadā in Tabaqāt al-Mu'tazilia. ${ }^{59}$

The end of 'Abd al-Jabbār's career as chief judge followed immediately after the death of al-Șăhib in AD 995, the reason apparently being his refusal to pronounce the funeral prayer for the remission of al-Șạhib’s sins. However, the historical evidence for this event is doubtful. Prince Fakhr al-Dawla nevertheless removed him from his position and confiscated all his possessions. But the prince died in AD 997, and his two sons ruled after him; Majd al-Dawla in Rayy, and Shams al-Dawla in Hamadhān. ${ }^{60}$ Both sons seem to have been weak as rulers and the widow of Fakhr al-Dawla, al-Sayyda Shīrīn, ruled over the whole Jibāl. However, Majd seems to have had an interest in Mu'tazilism because 'Abd al-Jabbār composed a book for him with the title al-Majd̄̄. Al-Sayyda appointed the Kurdish prince 'Alā' al-Dawla governor of Ișfahān, but he was able to distance himself from her authority and ruled independently. Al-Sayyda however retained her rule over Rayy until she died in $\mathrm{AD} 1028 .^{61}$ It seems that 'Abd al-Jabbār was not much influenced by all these new political arrangements but devoted himself to teaching and writing. Many more of his books were produced in this period:

1 Al-majmī fì al-Mubìt bi-al-Taklīf was probably written in AD 992;

2 Tatbbìt Dalā'il al-Nebuwwa - according to 'Abd al-Jabbār this book on prophecy was written in AD 995;

3 Tanzīh al-Qur'ān 'an al-Matā'in, a commentary on some verses in the Qur'ān;

4 Al-Majdī, written for Prince Majd al-Dawla probably on some Mu'tazilite concepts;

5 Fadl al-I'tizāl wa Tabaqāt al-Mu'tazilia, a source for Ibn al-Murtadā's Tabaqāt al-Mu'tazila which gives short biographies and evaluations of many Mu'tazilite masters;

6 Al-Amàlì fì al-Hadìth, a work on Hadìth and probably his last work.

'Abd al-Jabbār remained in Rayy until his death in either AD 1024 or $1025 .{ }^{62}$ He followed the theology of the Bașrian school which was distinct from that 
of the Baghdādī school. ${ }^{63}$ In al-Mughnī, his longest theological work, he refers frequently to Abū 'Alī (d. AD 915) and Abū Hāshim al-Jubbā'̄i (d. AD 933), the two best-known theologians of the Bașrian school. 'Abd al-Jabbār had a long productive life; Ibn al-Murtad̄ā mentions in Tabaqāt al-Mu'tazila ${ }^{64}$ about 27 different titles of his, ${ }^{65}$ but 'Abd al-Karim 'Uthman's research produced as many as 69 titles all attributed to 'Abd al-Jabbār. ${ }^{66}$ However, Brockelmann, as 'Uthman points out, has identified the existence of only nine works and he mentions the whereabouts of their manuscripts. ${ }^{67}$ The works of 'Abd al-Jabbār which are important for this book are Sharb al-Ușul al Khamsa, al-Muhīt bial-Takliff and al-Mughnī. We shall next give some details of these three works:

Sharḅ al-'Uṣul al-Khamsa 'Abd al-Karim 'Uthman, the editor of Sharh, considers that this work was not dictated by 'Abd al-Jabbār, but it is more probably a commentary by the Zaydite Mankadīm. ${ }^{68}$ Sharb presents "Abd al-Jabbār's discussion in an uncomplicated manner and a summary form which could suggest that this work is a collection of the lectures which 'Abd al-Jabbār used to offer to public and private students made by Ahmad Ibn al-Husayn, who was known as Mankadīm. ${ }^{69}$ The main purpose of this book is to give a clear Mu'tazilite and personal view of 'Abd al-Jabbār's theology, which mainly concerns the general basis of religion and sets out the main obligations. At the end of almost every chapter, Manqadīm says, "and this is the general obligation which is imposed upon every responsible person, mukalaf,"70 and then he gives an outline of the previous detailed point. Thus, this book is probably written for the general public. For this reason we will use Sharb in the chapter on 'Abd al-Jabbār, mainly to bring up a discussion of topics which are not found in al-Mubit or al-Mughnī.

Al-Majmū fì al-Mubìt bi-al-Taklīf ${ }^{\dagger 1}$ was probably written after 'Abd al-Jabbār completed his long work al-Mughnī in about AD $992 .{ }^{72}$ It exists only, Peters states, in the version of his disciple Abū Muhammad al-Hasan Ibn Ahmad Ibn Mattawiyya (d. AD 1076). Only the first of its four volumes has been published. ${ }^{73}$ The topics of this volume correspond to the topics of al-Mughnī, 1-8 and present their main arguments, suggesting that this work was an abridgement of al-Mughnī. Chapter 2 will make extensive use of al-Mubīt in presenting a summary of 'Abd al-Jabbār's arguments.

Al-Mughnī fì Abwāb al Tawhīd wa al-'Adl The most important work of 'Abd al-Jabbār is al-Mughnī. This consists of 20 volumes, 16 of which were found in Yemen in 1951. 'Abd al-Jabbār dictated this work over a period of 20 years from AD 972 to $992 .^{74}$ The discussion in this work is given in a direct

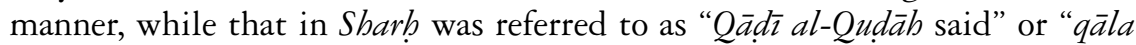
rabimabu allah." 75 Al-Mughni presents the detailed argumentation of "Abd al-Jabbār and discloses his theology as he himself structured it. Therefore in this work we will concentrate on $a l-M u g h n \bar{\imath}$ as my main source of reference.

'Abd al-Jabbār in al-Mughnī presents the Mu'tazilite theology in a coherent and systematic arrangement in order to form a set of unified ideas very closely 
related to each other. Although 'Abd al-Jabbār in al-Mughn̄̄ does not introduce a theology of his own but rather compiles a theology of the Basrian school under $A b \bar{u}$ 'Alī and Abū Hāshim al-Jubbāà', he presents his own reflections on their works and arranges the different theological issues in order to lead to a specific theological concept. ${ }^{76}$ We will first attempt to uncover certain characteristics of 'Abd al-Jabbār's treatment of the Mu'tazilite theology by elucidating the structure of al-Mughni.

'Abd al-Jabbār presents three different divisions of theology, all of which reveal his own apprehension of the position of God, human beings, the divine law and divine assistance. In the first division he sums up all theological issues under the two concepts of the unity of God, tawhìd and His justice, 'adl. All the theological issues which come under tawbìd are presented in al-Mughn $\bar{\imath} 1-5$. At the end of Volume 5, as Peters notes, he states that the treatise on tawbid is complete and the treatise on 'adl will follow, but he nowhere mentions that the treatise on 'adl is finished. ${ }^{77}$ This means that 'Abd al-Jabbār summarizes the five principles of the Mu'tazilite theology as apprehending God's essence and His acts of justice.

At the end of al-Mughnz 14, however, he informs us of another division which discloses his own understanding (Mu'tazilite) of theology. He explains here that the treatise on the rational obligations taklī ${ }^{\prime}$ aq $\bar{\imath}$ is completed ${ }^{78}$ and will follow the section on prophecies (the revealed obligations takliff sam' $\bar{\imath}$ ). In this, he divides al-Mughñ into two parts discussing the rational obligations in al-Mughñ 1-14, and the revealed obligations in al-Mughñ $15-19 .{ }^{79}$ Thus, 'Abd al-Jabbār declares here that theological issues are to be studied on two levels: there are, first, issues which may be mainly known to us through the rational reflection which must precede the study of revelation ${ }^{80}$; and, second, there are details revealed in the theological treatise which cannot be known by rational methods. These details have two functions: to reveal those commandments which are known only to God, and to disclose the characteristics of certain acts as assisting the performance of the rational obligations, as will be explained in Chapter 2 later. Thus, this division explains clearly the utmost abilities of the human intellect and discloses the main character of revealed knowledge as a branch of rational knowledge.

However, by reading al-Mughni we discover another structure which reveals 'Abd al-Jabbār's theological viewpoint. We recognize that al-Mughni 1-7 discloses the features and the characteristics of God: volume 1-5 explain His essential attributes and volumes 6 and 7 are mainly devoted to demonstrating the judgements of God's acts and the two temporal attributes which disclose God in His relation to the world - the attributes of will and speech.

Al-Mughni 8-12 deals mainly with human ability and knowledge: volumes $8-10$ discuss man's ability and power to act and his responsibility for what his acts generate. Al-Mughnī 11 discloses the importance of rational obligation, taklīf, and declares all humans "mukallafūn." Al-Mughnz̄ 12 is dedicated to examining human knowledge and its importance in accomplishing the rational obligation. 
After completing his treatise on the position of man he starts in al-Mughni 13 to discuss the relationship between God and mankind according to the concept of divine assistance, lutf. No Mu'tazilite theologian before 'Abd al-Jabbār seems to have given much attention to this concept, to which he devotes so much discussion in al-Mughnī 13. In Sharh, for example, Mankdīm writes a short chapter on lutf which simply presents 'Abd al-Jabbār's argument against Bishr Ibn al-Mu'tamir (d. AD 825/840). This shows that this issue was not discussed in detail among the Mu'tazilites. ${ }^{81}$ However, all subjects which follow al-Mughni 13 reveal the relationship between God and humans, which is disclosed in the conception of the divine assistance, lutf. Al-Mughni 14 explains the meaning of duty and explores the concept of repentance which relates humans to God. Volumes 15-17 of al-Mughnī discuss God's assistance, in sending prophets and giving human beings clear instructions which assist them to achieve what is rationally obligatory. Al-Mughni 18 and 19, since lost, must have covered, as Peters rightly maintains, the subjects of promise and threat and the intermediate position and the command to do what is good and to refrain from what is evil. All these subjects supply the details of the relationship between God and men, which is mainly based on divine assistance to obey the divine law. ${ }^{82}$

Thus, 'Abd al-Jabbār's modification of the Mu'tazilite theology in al-Mughni, which before his time was probably arranged mainly according to the five principles, ${ }^{83}$ emphasizes his concept of the dependence of human beings on God's assistance. Therefore, his emphasis on knowing the nature of God and the nature of humans and his explaining in al-Mughn $\bar{\imath} 13$ the great importance of God's assistance, indicates his own interpretation of Mu'tazilite theology.

\section{Ibn Sīnā}

The name Abūū 'Alī al-Husayn Ibn 'Abdullah Ibn Hasan Ibn 'Alī Ibn Sīnā, by way of Hebrew, became Europeanized into Avicenna. He was born in August AD 980 in a large village near Būkhārā called Kharmmithan and died near Ișfahān in June or July AD 1037. In the course of his life he moved to many towns in Persia because of the political changes of the period, when the Ghaznawid sultans were constantly attacking Buyid territories. His father was the governor of the village where he was born. He was an Ismā'îli and taught his two sons, the elder of whom was Ibn Sīnā, the Qur'ān and religious knowledge according to Ismā'īlī concepts. ${ }^{84}$

The main events of Ibn Sīnā's life are known to us through an autobiography begun by himself and completed by his friend and lifelong companion al-Jūzjāni. At the age of 10, Ibn Sīnā started his actual study of philosophy under the teaching of Abū 'Abdullah al-Natelī, about whom Ibn Sīnā claimed that he pretended to be a philosopher. Ibn Sīnā introduces his scientific education in terms of the Aristotelian curriculum, which consists of logic, mathematics, physics and metaphysics. After the primary period he 
specialized in medicine. In his autobiography, however, he claims that he had no masters and finished his formal education by the age of 18 . After this he is said never to have learned anything new. ${ }^{85}$

He became famous as a physician at an early age when, after the failure of many other physicians, he cured the son of Prince Nūḥ Ibn Manșūr al-Sāmānī of Būkhārā. The prince in return allowed him to use the royal library, which Ibn Sīnā considered the greatest he had ever seen. In this period Ibn Sīnā tells us that he composed four works (most probably between the ages of 21 and 23): The Compendium on the Soul, Philosophy for 'Urüdì (some parts of which have been published), the lost al-Hāșil wa al-Mabsüul in 20 volumes and his only ethical work, al-Birr wa al-Ithm, also lost. ${ }^{86}$

However, after the death of his father he was obliged to earn his own living; for some reason he left Būkhārā and accepted a post in Jurjaniyya. He did not stay long in this post but moved to the court of Prince 'Aī Ibn Ma'mūn Khawārizm and won the patronage of his vizier, Abū al-Hasan al-Suhaīlī' for whom he wrote Kitāb al-Tadāruk li-Anwā' al-Khața' fì al-Tadbìr and Qiyām al-'Ard fì al-Wasat. But the Ghaznawid Sultan Muhmoud was threatening to attack Jurjān and therefore Ibn Sīnā had to flee from the fanatic orthodox sultan. He set off for the court of Shaykh al-Ma'ālī Qābūs, visiting on his way, it is said, the Sufi sage Abū Sa 'īd Ibn Abī'l-Khayr. However, by the time he arrived at the Shaykh Qābūs' court he found him dead. Ibn Sinnā was then obliged to return to Jurjān and this time he met someone who would become his lifelong friend, Abū 'Ubayd al-Jūzjānī, who from this point continued to write their adventures together. ${ }^{87}$ He stayed

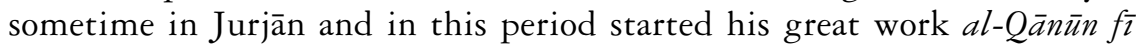
al-Tibb (known as the Canon). Besides working on this he also composed al-Mukbtasar al-Awsat (The Middle Summary), Al-Mabd' wa al-Ma'äd (The Beginning and the Return), al-Arșād al-Kullizya (General Observation) and Al-Mukbtașr al-Majistī (The Majestic Summary). ${ }^{88}$

He then left Jurjān to stay in Rayy in about AD 1015 but did not stay long because of the dissension between the young Prince Majd al-Dawla and his mother, who wanted to rule in his name. Ibn Sinnā became the physician of this prince and opposed the authority of his mother. Soon he had to leave for Hamadhān, where he started a new phase in his life. He became the favourite of Prince Shams al-Dawla, who appointed him vizier. However, al-Jūzjānī tells us that he himself always supported Ibn Sinnā’s philosophical career as against his political one. He was a vizier in the daytime but in the evenings he held learning sessions and studied at night. In this period he started his great

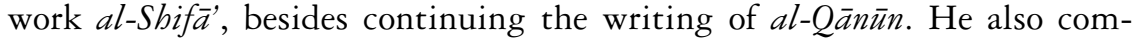
posed in this period The State of the Human Soul and the book called Guidance, al-bidāya. After some time the Prince decided to go to war and took Ibn Sīnā with him. But during the war the Prince died of a severe attack of colic in AD 1021. The new Prince was not fond of Ibn Sinnā, especially after he refused to be reappointed as vizier. He was then arrested and kept in the fortress of 
Fardajān. ${ }^{89}$ In his captivity he composed the treatise Hayy Ibn Yaqzānn. ${ }^{90}$ After four months, however, Hamadhān was captured and Ibn Sīnā was set free; he escaped to Iṣfahān with al-Jūzjānī and his brother.

'Alā' al-Dawla, the ruler of Ișfahān, valued the talent of Ibn Sīnā and every Friday held a meeting with Ibn Sīnā and a group of learned men. This was the end of Ibn Sīnā's political career but the beginning of his philosophical one. In his Ișfahān period, which lasted about ten years, he composed all the rest of his works, which Gutas arranges in the following chronological order:

1 The last parts of The Cure (al-Shifá) in AD 1027;

2 The Salvation, (al-Najāt) in AD 1027;

3 Philosophy for 'Alā' al-Dawla, the only book written in Persian under the title Dānish Nameh ye 'Alà' $\bar{\imath}$;

4 The Eastern Philosophy in AD 1027-9 (lost);

5 Fair Judgement, (al-Inșāf) a commentary on the pseudo-Aristotle's Theologia Aristotelis in 20 volumes in AD 1029 (lost);

6 Marginal Notes on De Anima;

7 Remarks and Admonitions (al-Ishārāt wa al-Tanbihāt) in AD 1030-4;

8 Letter to an Anonymous Disciple in AD 1034;

9 Letter to Kiya in AD 1036;

10 On the Rational Soul in $\mathrm{AD} 1037 .^{91}$

Ibn Sinnā also composed many treatises, the most important of which are The Treatise on Love (Risāla fì $a l-{ }^{\prime} I s h q$ ), The Treatise on the Nature of Prayers (Risāla fì Māhayat al-Salāb), The Treatise on Happiness (Risāla fī al-Sa'āda), The Treatise on the Throne (al-Risala al-'Arshiya), Recital of the Bird (Riasālat al-Ṭayr) and others. Ibn Sīnā lived in Ișfahān until he died, after much suffering, from colic in June or July AD $1037 . .^{92}$

The works of Ibn Sīnā' which are important for the purposes of this book are al-Shifä' (The Cure) and its abridgement al-Najāt (The Salvation), al-Ishārāt wa al-Tanbīhāt (Remarks and Admonitions) and Risāla fī al-'Ishq (The Treatise on Love).

Shifā', Najāt and Ishārāt are encyclopaedic works which contain Ibn Sīnā's teaching on logic, mathematics, physics, metaphysics and theology. Shifä was first composed in AD 1020 and finished in AD 1027 together with Najāt. Three years later, Ibn Sīnā started his last great work Ishārāt, which was finished in AD 1034, three years before he died. This present book, however, is only concerned with those parts which study the human soul in relation to physics and the parts on theology. In the main, Ibn Sīnā follows the Aristotelian tradition in his interpretation of the above sciences, but the theological part of his metaphysics is also influenced by Neoplatonic thought, through what the Arab translators called The Theologia Aristotelis some parts of Plotinus' Enneads (4-6), which the Arab translators falsely 
attributed to Aristotle. ${ }^{93}$ However, Ibn Sīnā is not only commenting on those Aristotelian and Plotinian works but also adding some vital theories which constitute his own view. He makes this clear in the Prologue to al-Shifä':

there is nothing of account to be found in the books of the ancients which we did not include in this book of ours... To this I added some of the things I perceived through my own reflection and whose validity I determined through my own theoretical analysis, especially in Physics and Metaphysics - and even in Logic. ${ }^{94}$

Ibn Sīnā significantly adds to the psychological part of Aristotle's Physics his new theories on learning through intuition and the substantial nature of the human soul. He also provides a long analysis of the nature of universal ideas which is fully abstract, as will be shown in the section on rational knowledge in Chapter 3 below. In addition, he offers some significant theories and interpretations of the nature of God in the theological part of the metaphysics. He introduces the concept of Necessary Existence to explain that God's unity means that $\mathrm{He}$ is One because His existence is within His essence, whereas the existence of all other beings is dependent on another. Chapter 3, in the main, seeks to reveal some of the characteristics of Ibn Sīnā's new contributions which led him to compose the last Sufi-influenced part of al-Ishärāt wa al-Tanbībāt (Remarks and Admonitions), which demonstrates the ultimate relationship between the Divine and some human souls.

Ibn Sīnās last encyclopaedic work Ishārāt is, indeed, very important for this work. He divides this work into two: the first part is on logic and the second surveys physics and metaphysics in ten chapters which he calls namatannmāt (classes). ${ }^{95}$ The main importance of this work lies in two of its features: in the method, which "depend [s] on providing hints and guidelines, rather than ready-made arguments, to the student, who is then expected to elaborate the entire theory on his/her own", ${ }^{96}$ he is also in many of these points trying to disclose the nature of the problem in certain parts of the discussion. The second characteristic of this work lies in introducing a Sufi dimension to the theological division of the metaphysical part. ${ }^{97}$ In these last classes (8-9), he demonstrates the possibility of the ascent of some human souls to reach the absolute manifestation of God which he refers to as tajalli. In the tenth and last class he explains the nature of the miracles which these Sufi saints are able to perform. ${ }^{98}$

Chapter 3 will also make great use of Ibn Sīnā's treatise Risāla fì al-'Ishq (The Treatise on Love) which, we believe, introduces the mystical dimension of his philosophy. ${ }^{99}$ In this treatise Ibn Sīnā interprets the relationship between the different species (i.e. matter and form, movement and Movers, souls and Intellects and finally Intellects and God) as having its basis in the yearning towards love and perfection which is for some the continuation of existence and for others the yearning for perfection in God. But only the divine Intellects have an eternal relationship with God's manifestation of 
knowledge, goodness and love. It seems that there is a close link between this treatise and those chapters on Sufism in Ishārāt because in chapters 17 and 18 of the eighth class he gives a summary of this treatise with some explanation of the meaning of "yearning." 100 This probably shows that this treatise was composed shortly before Ishārāt.

However, Chapter 3 will also make use of some other works of Ibn Sīnā, such as Risāla fì Mäbiyyat al-Salāt (The Treatise on the Nature of Prayer) and some parts of his work Kitāb al-Inșâf (Fair Judgement or The Commentary on Theologia Aristotelis).

\section{Al-Ghazālī}

Abū Ḥāmid Muḥammad Ibn Muhammad Ibn al-Ta’us Aḥmad al-Ṭ̂̄s̄̄, known as al-Ghazālī, because his father was probably a spinner, ghazzāl, and as Hujjat al-Islām, the proof of Islam, was born in Ṭūs in AD 1058. Al-Ghazālī was one of the most famous and influential scholars in the history of Islam because he presented Islamic concepts in depth, without losing their Islamic basis, and in a highly philosophical manner. He described the different stages of his life in his famous work al-Munqidh min al-Daläl. ${ }^{101} \mathrm{M}$. W. Watt, however, considers this work to present more an evaluation of the important stages of his thought and experiences than a biographical account of his life. The life of al-Ghazāli can be divided into five distinct periods: the period of his study and early teaching in Nīshāpūr, the second period covering his teaching in Baghdād, the third period of his Sufi journeys, the fourth consisting of his return to teaching in Nīshāpūr and finally his retirement and death in Ṭ̂us.

In his birthplace, Ghazālī started his studies in the subject of jurisprudence, but left in AD 1077-8 in order to study under the famous Shāfa $\overline{1}$ scholar Abū al-Ma'ālī al-Juwāynī in Nīshāpūr. He stayed in Nīshāpūr from $\mathrm{AD} 1077$ to 1091, at first studying the following sciences under al-Juwāynī: Ash'arite theology, philosophy, logic and the natural sciences. ${ }^{102}$ Smith comments that Ghazāle in this period had already become impatient with dry dogmatic teaching and began to study Sufism under Abū 'Alī al-Faḍl Ibn Muhammad Ibn 'Al̄̄ al-Farmādhī. ${ }^{103}$ Ghazālī however, mentions in Munqidh that his Sufi studies began in Baghdād after he had written Tahāfut al-Falāsifa.

After the death of his teacher al-Juwāynī in AD 1085 in Nīshāpūr, Ghazālī began his teaching career and became a famous scholar known to the vizier Nizām al-Mulk who was interested in Ash'arite theology and Sufism. He admired Ghazālī as a Shāf'̄ scholar and sent him as a director of the Nizāmiyya College in Baghdād in AD 1091. ${ }^{104}$

The works of Ghazālī in this period concentrated on jurisprudence and Ash'arite law. Hourani mentions seven works, namely, (1) al-Mankbūl fi Us $\bar{u} l$ al-Fiqh, (2) Shifā' al-Ghalīl fi al-Qyās, (3) al-Basīt, (4) al-Wasīt, (5) al-Wājiz fi Fiqh al-Imām al-Shāf'ī, (6) Khulāșt al-Mukbtașar wa Naqāwat al-Mu'tasir and (7) Tabdhīb al-Ușīl. ${ }^{105}$ 
In the second period Ghazālī was sent to teach in al-Nizāmiyya College in Baghdād. He spent only four years in Iraq, from AD 1091 to 1095. In this period he wrote most of his philosophical writings, probably to impress the scholars of the capital of the great 'Abbasid empire. As mentioned above, Smith shows that he was already studying philosophy and Sufism in Nīshāpūr, although Ghazālī in Munqidh mentions that both his philosophical and Sufi study was in Baghdād. This statement, however, must not be taken as chronologically true but probably means that his interest in Sufism came after his philosophical critical writings. This is also supported by the fact that al-Ghazālī's stay in Baghdād was only for four years; he was occupied there by teaching, answering fiqh questions from the public and writing his most important books, as shown in the following list:

Maqāsid al-Falāsifa In this book he explains the main schools of philosophy as an introduction to his next work.

Tahâfut al-Falāsifa This became one of his most famous books. The aim of this book is to demonstrate that the assumptions which the Arab philosophers took over from the Greeks in their study of physics and metaphysics are not provable and lack the certainty which they provide in mathematics. Ibn al-Rushd, a hundred years after Tahaffut, attempted to prove the authenticity of these assumptions, from his philosophical point of view, in his book Tahäfut al-Tabāfut. ${ }^{106}$

Mi'yār al-'Ilm fí Fann al-Mantiq and Mibak al-Nazar These are his most famous works of logic. ${ }^{107}$ It seems that in these two books he built the foundations for a thorough method of acquiring rational knowledge in the religious sciences. He often remarks in his work that the only scholars who can acquire true rational knowledge are the ones who are rooted in thorough methods of investigation. Thus, logic for him provides the path which leads to certitude.

Al-Mustazhiri or Fadä' ih al-Batiniyya This is a work which refutes the Isma'ili Ta'timina belief in the superiority of the Imam in interpreting the Qur'ān and religion.

Hujat al Haqq and al-Iqtișād fì al-I'tiqūd These works belong to the same period as al-Mustazhirī. The latter reveals his theological views; probably after all his great philosophical works Ghazālī was accused of arguing in the same manner as the philosophers and in Iqtișād he wanted to demonstrate his theological beliefs in the language of the Mutkallimūn. Nevertheless, the theology which he provides in this work is not pure Ash'arite theology but very much his own, influenced by philosophical concepts about the essence of God, as is shown in Chapter 4, the section titled "The problem of the attributes of God."

Mìzān al-'aml The last book of this period (probably when he was still in Baghdād) is his philosophical Sufi work Mīzān al-'aml. It seems that this work is the introduction to $I b y \bar{a}$. There are many passages of $M \bar{i} z \bar{a} n$ which are found in detail in I $b y \bar{a}$ '. ${ }^{108}$ A good deal of both Sharb 'aja' $i b$ al-qlab and ryādat al-Nafs, the first two books of the third volume of Ibya ' are taken 
from $M \bar{\imath} z \bar{a} n$. In this work he tries to find the connection between theoretical sciences and the practical actions which constitute human behaviour.

After Ghazālī became famous in Baghdād, he passed through a crisis, ending with his finding certitude in Sufism. When he left Baghdād this time he probably stayed in Damascus for a while on his way to Mecca. It is also possible that he visited Egypt and stayed there for a short time either on the way to Mecca or at an earlier period from Baghdād. If his journey to Egypt is authentic then there is a greater possibility of accepting as his the polemic work al-Radd al-Jamīl which is a work attributed to Ghazālī ${ }^{109}$ refuting the Christian belief in the divinity of Jesus Christ.

This is a very interesting work which compares such statements of Jesus as "I am the truth" with their equivalents from al-Hallāj and Biṣtāmī. The author shows that the biblical statements which confirm the divinity of Jesus must be interpreted metaphorically and points out that Jesus' experience with God is similar to the Sufi concept of annihilation and union. ${ }^{110}$ H. Lazarus-Yafeh, however, shows in her book, Studies on al-Ghazzāal, that this work could not have been written by al-Ghazālī. Her main argument rests on her thesis that all the books which al-Ghazālī wrote after he began to follow Sufism are distinguished by a new style of writing, which avoids the use of philosophical language and terminology. She also notes that the author of this book refers familiarly to the Bible, a feature which al-Ghazālī does not show in his other Sufi works mentioning Jesus. ${ }^{111}$ Although Lazarus-Yafeh's arguments are strong, there are at least a few points which should be considered. First, it is quite obvious that al-Ghazālī used more than one style of writing in the time before his conversion to Sufism, when he wrote to different groups of thinkers in the same period. This can be seen in his Tabäfut, which uses philosophical language, while his Iqtișād is written in a totally different style and is directed at theologians. This shows that Ghazālī was not restricted to one writing style and could freely use whatever was the appropriate style for certain readers. Consequently, it is not certain that Ghazālī totally avoided any style if he found a reason for using it. Besides, since al-Ghazālī's late writings were mainly directed at the Sufis, it is obvious then that he would not have used philosophical terminology, but this does not mean that he never used another style when it was necessary to use it. However, that al-Ghazālī in his Sufi writings does not give references from the Bible when he mentions one of Jesus' sayings, is quite reasonable. Since al-Ghazālī was writing to Sufis who are not familiar with the Bible, there is no reason why he should provide these references. However, in the case of refuting the Christian belief in the Trinity, his readers, both Muslim and Christian, require evidence for his thesis, which he must provide.

In any case the certainty which al-Ghazālī found in Sufism, in the third period, did not mean a full rejection of his philosophical thought; certainly none of his Sufi works of this period deny the philosophical line which he 
had mastered before. In fact, they all make great use of it, as we will show throughout the chapter on al-Ghazālī. He assimilated his philosophical knowledge into his Sufi concepts and connected both with the basic Islamic and (interpreted) Qur'ānic concepts. Thus, it seems to us that al-Ghazālī's works of this period demonstrate a continuation in another direction rather than the start of a new career, as he describes it in Munqidh. ${ }^{112}$ Hence Munqidh, as Lazarus-Yafeh maintains, seems to be written for the public as a literary text ${ }^{113}$ and consequently should not be taken as a literal biography of Ghazālī. Nevertheless, he must have passed through a certain crisis which made him decide to leave his important post in Nizāmiyya College. At all events, his sincerity in following Sufism is demonstrated in all the books of this period. He wrote 11 works during this time, under which are included the 40 books of $I b y \vec{a}$. The chronology of these books, according to Hourani, is as follows:

\section{Al-Risala al-Qudsiyya is a short treatise written for the people of Jerusalem.}

Ibyā' 'Ulüm al-Dīn is the famous encyclopaedia of religious sciences. Although he devotes this work to the science of analysing human behaviour, 'ulüm al-mu'ámala, in many places, especially in the fourth volume, he discloses a great many of his mystical visions and experiences ${ }^{114}$ which he considers to be the inspired sciences 'ulüm al-mukäshafa. The whole work aims to radiate mystical and spiritual concepts in understanding the role of religion in the journey to the knowledge of God. This work is written for the well-informed ordinary seeker of truth and to encourage the elite in seeking further knowledge.

Al-Risāla al-W'aziyya Ayyuhā al-walad In both those works al-Ghazālī exhibits his ethical theories.

Al-Imlä' fì Ishkālät al-Ibya $\bar{a}$ this work discusses the problems which emerged from al-Ghazālī's publication of Ibyā' 'Ulüm al-Dīn.

Al-Maqșad al-Asnā Here al-Ghazālī gives a mystical profound interpretation of God's 99 names.

Jwāhir al-Qur'an A work which give a mystical interpretation of some verses of the Qur'ān which he consider to be the jewelleries of the Qur'ān.

Kitāb al-Arba'in this is a work which is written in Persian and is a short abridgement of Ihyā'?

Mishkāt al-Anwār Al-Ghazālī’s deepest mystical work which unveils his Gnostic beliefs. In its introduction, al-Ghazāli makes clear that this work is written for the elite Sufis who stand in the highest Sufi stages.

Kitāb al-Daraj Not a well known Sufi work of al-Ghazālī and

Al-Qisțāt al-Mustaqīm A simple work in logic written in religious language against the Bățini logics and aimed to convince narrow minded believer who are attracted to Bāṭini propaganda. ${ }^{115}$

After 11 years of Sufi life, in the fourth period, al-Ghazāli returned to his teaching job in Nishāpūr in AD 1106. Most of the books he wrote in this 
period are mainly for the public. Only two works discuss Sufi subjects; al-Munqidh and Kìmyā' Sa'ädat (Alchemy of Happiness). In this period he wrote the following six books:

Faysal al-Tafriqa This is partly directed against the Batiniyya sect but mainly is a defence of al-Ghazālī theory of 'Ta'wīl (interpretation).

Kìmyà' $S a^{\prime} \bar{a} d a t$ (Alchemy of Happiness) Written in Persian, is considered equivalent to Ihyā' in the Persian language.

The Refutation of the Permissive Scholars polemical work against Sufis who are antinomianism written in Persian.

Nașīhat al-Melük An ethical work written in Persian.

al-Munqidh nim al-Dalāl A famous work which al-Ghazālī's wrote to give some evaluations to the different stages of his life journey. This work, however, should not consider a biography of al-Ghazālī's life which presents chronological events of his life.

Al-Mustasfa Is one of his longest works on Islamic law, Fiqh. ${ }^{116}$

Finally, Ghazālī returned to the town of his birth, Ṭūs, and some days after he finished his last work, Iljām al-'Awām, a work which warns from teaching Islamic theology to the publics. In Ṭūs, al-Ghazālī spent his last days and he died on 8 December AD 1111. ${ }^{117}$

There are many books attributed to al-Ghazālī which recent scholarship has shown to be inauthentic. Most of these works are very much influenced by Neoplatonic concepts and terminology. ${ }^{118}$ Lazarus-Yafeh and others have found methods for rejecting some inauthentic works, which in the past influenced the writings of some scholars such as Margaret Smith, in some parts of Al-Ghazālī the Mystic, ${ }^{119}$ and Rahman in his study of al-Ghazālī's theory of prophecy in two inauthentic Neoplatonic works attributed to him. ${ }^{120}$ Lazarus-Yafeh's important work, Studies on al-Ghazzālì shows that after Tahāfut al-Ghazālī abandoned the use of philosophical terminology and used instead only such philosophical images and concepts as did not contradict the basic concepts of Islam. He rejected the use of language which is based on direct philosophical terms, such as al-'aql al-kullì, al-'aql al-fa" 'äl or al-nafs al-kulliyya and instead used terms such as al-lawh al-Mabfüz, preserved on a tablet, or nūr al-'aql $l^{121}$ and $r \bar{u} b$ al-quds. ${ }^{122}$ Therefore, in this chapter we will refer only to al-Ghazālī's authentic works as listed in the article of G. F. Hourani, "A Revised Chronology of al-Ghazālīs Writings."123

This book will in fact concentrate on three of al-Ghazālīs works Tahâfut al-Falāsifa, Ibyā' 'Ulūm al-Dīn and Mishkāt al-Anwār as follows:

Tabāfut This is one of his most famous works, which was written in al-Ghazālī’s last period in Baghdād. In this he criticizes the Arab philosophers, especially Ibn Sinnā. Although Tabāfut is famous as the first Arabic work which criticizes philosophy by means of the same philosophical methods and logic, Ghazālī here was only criticizing a certain aspect of philosophy. His aim was to 
demonstrate that the theological part of Ibn Sīnā's (and al-Fārābī’s) metaphysics does not present the same kind of certitude that other parts of philosophy do. ${ }^{124}$ Many religious concepts, he explains, cannot be proved on the basis of rational logic, and he therefore asks such questions as how do you know that the oneness of God can only produce one entity, or how do you know that the eternal knowledge of God cannot know this, as we will show in things which are capable of change. In this manner he wants to assert the existence of knowledge which cannot be proved but is revealed. Thus, al-Ghazāli in Tahäfut seeks to demonstrate the limitations of philosophy, rather than attacking it in order to prove its unreliability (see Chapter 3, section titled "The main characteristics of God").

Ibyä' 'Ulüm al-Dīn (The Revival of the Religious Sciences) This is his great work that consists of 40 books compiled in four volumes. This work was probably written at different periods, as can be verified by comparing the first volume with the fourth, which demonstrates his mystical concepts. We will refer to the problems over the consistency of this work in Chapter 3, section titled "Relationship with God through His manifestation of Himself, Tajall". The first volume of Ibya $\bar{a}$ ' explores the concept of worship and the second discusses the importance of Islamic customs in the preparatory stages of Sufism and the third examines the difficulties which the human soul must overcome in order to reach the first stages of the Sufi path. The last division describes the different stages of the Sufi path. From the title we understand that the author wishes to present a new interpretation of religious concepts. $\mathrm{He}$ is referring here to the interpretation of religion by a mystical dimension. He illustrates in the introduction that the purpose of the work is the purification of the human soul from destructive evil habits of the body and heart and its deliverance through some virtues, such as patience, hope, asceticism, trust and love, to eternal happiness. ${ }^{125}$

Mishkāt al-Anwār This is one of his late works but was probably written during the period of his Sufi wanderings. In this short work he answers the request of a beloved student. Its main object is to explain the verses in light of the Sürat al-Nür and the famous Hadīth on the different veils which conceal God from the unworthy. Al-Ghazālī in explaining the motif of light takes the opportunity to set out his deepest views of the Sufi concepts of annihilation and union. Here he accepts what he rejects in some parts of $I b y \vec{a}$, that the Sufi will be able to see God in this life and enter into His presence. However, he meditates on the concept of union, showing its depth: this should not be taken to mean that the Sufi becomes God but that he moves into an area where he/she cannot identify or be identified. The last chapter of Mishkāt, however, has caused a number of arguments; the first to point out the ambiguity of this chapter was W. H. T. Gairdner in his article "Ghazālì's Mishkāt al-Anwār and the Ghazālī problem." 126 He outlines the problem of the image of God at the end of the chapter, which made Watt doubt the authenticity of this part. ${ }^{127}$ Since then many have argued about it and scholars such as 'Afifi, H. A. Davidson, A. Landolt and Lazarus-Yafeh find 
Watt's assertion unconvincing. ${ }^{128}$ However, al-Ghazāli $\overline{1}$ at the end of this chapter presents God as a mysterious being; he explains that only those who attain the truth in their mystical experience could arrive at a Being who is above all that is perceived empirically or by insight. This image however is fully justified in his other works, as will be shown in Chapter 3, section titled "Relationship with God through His manifestation of Himself, Tajalli."

\section{Development of $l u t f$, 'ishq and fanä'}

Lutf, 'ishq and fan $\bar{a}$ ' are three concepts which were already being discussed among theologians, philosophers and Sufis in the ninth century and which disclose three different rational understandings of the relationship between God and humanity. Here we shall provide a summary of these discussions with the aim of supplying a contextual background for 'Abd al-Jabbār, Ibn Sinnā and al-Ghazālī’s understanding of those concepts.

\section{Divine assistance, luṭf}

Al-Ash'arī in his Maqālāt al-Islāmiyȳin summarizes the discussions of the different groups in his time on the question of God's assistance to show the most important aspects of divine assistance as presented by the most prominent scholars. Here we will use his summary to provide contextual arguments surrounding the concept of lutf in 'Abd al-Jabbār. ${ }^{129}$ In this context al-Ash'arī mentions three main groups: the Ahl al-Ithbāt, who are probably the followers of Ibn Kullāb and the Ahl al-Jamā'a wa al-Sunna; the Baghdād̄̄ Mu'tazilites, Bishr Ibn al-Mu'tamir and Ja'far Ibn Harb and the Bașrian Mu'tazilites. It seems from his 11 entries on this question that Bishr and Ja'far from the Baghdādī Mu'tazilites agree with Ahl al-Ithbāt, the traditionalists, on their understanding of all aspects of the divine assistance. ${ }^{130} \mathrm{Al}$-Ash'arī here provides four areas of discussion on lutf which can be summed up in four questions: (1) would this divine assistance necessarily turn an unbeliever to a believer?, (2) is divine assistance infinite?, (3) could God offer better assistance than $\mathrm{He}$ actually provides? and (4) is this assistance a duty and is it a necessity which God must undertake?

To answer the first question, al-Ash'arī discusses two main points. The first considers that an unbeliever who receives God's assistance would beyond doubt be guided and would repent for his/her sin. This is the opinion of both Ahl al-Ithbāt and the two Baghdādī scholars Bishr Ibn al-Mu'tamir and Ja'far Ibn Harb: the former group base it on their belief in divine determination, which declares that God is the only agent and humans are not free in their choice but fully dependent on God's will and guidance, whereas the latter group base it on the fact that when divine assistance is provided to unbelievers it must be beyond doubt that they believe. ${ }^{131}$ This is implied in Bishr's argument about the necessity of the divine assistance that if divine assistance were a duty then God would have had to provide it to all unbelievers and the 
world would not contain any sinners, which is not what we experience. This demonstrates his belief that divine assistance would certainly turn an unbeliever into a believer. In contrast to both groups, the Bașrian $\mathrm{Mu}$ 'tazilites such as Nazzām and Abū al-Hudhayl show that God's assistance only motivates unbelievers but does not compel them to believe. For them, all human decisions depend fully on their free choice and God's assistance is no exception to this rule. ${ }^{132}$

Concerning the two questions whether God gives infinite assistances, altā $\bar{f}$, and that this can be better than what He provides, al-Ash arī again supplies two main answers. Before we look at them, it is important to remember that the aim of discussing these two aspects was to counter the opinion of the group called Aṣhāb al-Aṣlah, who considered that all God's acts were directed to the greatest good of His people and that therefore $\mathrm{He}$ always provides His best. This in fact means that God could not give better assistance than $\mathrm{He}$ actually gives to His people. ${ }^{133}$ Thus, the Ahl al-Ithbāt considers that this limits God's ability and power to what we experience. In contrast, they believe that God has endless alta $\bar{f}$ which is better than what he provides, but His grace flows according to His will and knowledge of the need. Bishr also considers that God's assistance is infinite and more than what He shows to His creatures; He only reveals what is good for them. Nazzām and Abū al-Hudhayl, on the contrary, consider that God has endless lutf, not better than what He already provides but similar to it. For to say otherwise means either that God is not able to provide this highest assistance, which would imply a deficiency, or that He does not want to offer the highest assistance, which would portray $\mathrm{Him}$ as ungenerous. ${ }^{134} \mathrm{Al}$-'Ash'ari also adds that, according to Abū 'Alī al-Jubā'̄î, if God knows, however, that some one would have a higher level of belief if He refrains from assisting him/her, then in this case God will restrict this assistance. ${ }^{135}$

Concerning the obligation on God to offer divine assistance, most groups, except the Bașrian Mu'tazilites, did not accept the necessity of divine assistance and considered God's guidance as pure grace, which God offers to whomever He chooses. Bisher ibn al-Mu'tamir, the Baghdādī Mu'tazilite, also denies that divine assistance is a duty which God must extend to those who otherwise would be able to believe. ${ }^{136} \mathrm{~A}$ more detailed discussion of Bishr's argument will be provided in Chapter 2, section titled "Communication through God's duty of assistance, lutf" together with a detailed account of 'Abd al-Jabbār's concept of lutf, which refutes most of the above discussion.

\section{Divine Love, 'Ishq}

'Ishq as a mystical concept was discussed long before Ibn Sīnā's composition of Risāla fì al-'Ishq. It was Rābi'a al-'Adawiyya (d. AD 801), a Sufi woman from the eighth century, who first introduced divine love into Islamic mysticism and demonstrated that Sufis are those who seek God as their lover Who is 
loved for who He is and not for His rewards, buban li-dhätibi. This moved Sufism from being a traditional kind of pietism to a search for the mysterious beloved. Recently B. Abrahamov has dealt with this subject in his book Divine Love in Islamic Mysticism, comparing al-Ghazālīss concept of divine love with that of al-Dabbāgh. ${ }^{137}$ In the introduction Abrahamov traces the long development of divine love in Islamic thinking, showing how this subject was treated among the Greek thinkers, Jewish and Christian theologians, Arab philosophers and Sufis. Here, we will follow Abrahamov's account to the extent which is appropriate to this part of the chapter.

Every work which studies the 'Ishq of Ibn Sīnā must start from the Greek philosophers who profoundly influenced Islamic thinking. The most prominent Greek thinker who started the discussion on divine love is, indeed, Plato. Plato's image of the universe is clear from his division of the world into two levels: the divine world of absolute reality and the world of shadow. Humans as the inhabitants of the latter world are living in illusion far from acknowledging the real world and therefore the most important motivation which moves humans from the world of illusion to the divine world of truth is their experience of love. ${ }^{138}$ This love is experienced on different levels: it starts by the appreciation of the materially beautiful, but moves on from this stage to a deeper appreciation of character and soul behind this beauty. At this stage one realizes the importance of social and moral nobility and moves to an appreciation of the importance of knowledge which elevates the soul to higher virtues and to the discovery of the real and absolute beauty of the eternal world. Thus divine love is a development: first we realize it in material beauty and then we move to acknowledge spiritual eternal beauty.

Although Aristotle does not accept the duality theory of the two worlds of Plato, he does make a great contribution to the concept of divine love. He considers that love is a spiritual power similar to the power of the forms which are embodied in all material things. As the role of the form is to bring matter into existence, love is the power which motivates its preservation and continuity. In order that a thing should continue to exist, it must be motivated through a continuous yearning to come closer to its immediate cause. Matter has an innate yearning toward form and moves toward its Mover, as the whole world turns to its Prime Mover. Thus, love is the power which keeps the world in unity and presents as its aim the movement of love towards its Prime Mover (God). ${ }^{139}$

Plotinus goes further in explaining how this actually happens: it is through the emanation of the prime eternal love of the One to the intellect and the soul that love becomes the inseparable element which flows in all things and motivates their innate yearning to return to their origin, the One (God). Therefore love in Platonic, Aristotelian and Neoplatonic thinking is the element which guarantees the unity of the world and its connection to God. ${ }^{140}$

This concept of divine love is, in fact, not far from the Qur'ānic concept; many verses of the Qur'ān refer to God's love but mainly in the sense of God's loving the good and hating evil: "God loves not the evil doers" (3:134) 
"God loves the good doers" (3:140) and the like. Similar to the concept of God in Greek thought, God in Islamic theology is also not considered to have a feeling of love towards anyone in particular because this kind of love would influence the transcendence of God and reduce Him to a human level. This concept is based on the Qur'ānic verse "Nothing is like unto God" (42:11). Baqillānī (d. AD 1013) and other Ash 'arite and Mu tazilite theologians consider that love would denote a change in the essence of the lover but since God's essence is unchangeable it is not appropriate to attribute love to Him. ${ }^{141}$

While the Muslim theologians were not interested in interpreting and investigating the theory of divine love, Muslim mystics considered divine love as the highest attainable object. After Rābi'a al-'Adawiyya's introduction of the concept of bubun li-dhatibi, love for God on the basis of who He is, as the aim of the mystic path, divine love was approached from two directions: first, al-Muhāsibī’s school in Baghdād developed divine love as the highest stage of Sufi path. In this stage the Sufis fully identify their will with God's will. Second, divine love was developed by the school of al-Junayd, which was Neoplatonic in tendency. Divine love here did not itself occupy the highest stage but was the stage which leads to self-annihilation and union with God. ${ }^{142}$ More details on this subject will be provided when dealing with the Sufism of al-Ghazālī in Chapter 4.

The most important group for our study here is the mysterious philosophical group which was known at the end of the tenth century under the name Ikhwān al-Ṣafā, the Brethren of Purity. Although al-Kindī and al-Fārābī wrote brief notes on the subject of love, the Brethren were the first who devoted a long study to The Definition of Love, fì mähiyat al-'Ishq, in their work Rasä'il Ikbwān al-Șafā. The Brethren start their epistle by presenting different definitions of love and add their own definition, that love is the strong longing for union. Following the Greek concepts mentioned above, the Brethren consider that love is an implanted element in all things which demonstrates the longing of the thing to approach its perfection. Thus, each thing is longing to approach what stands higher than it in the hierarchy of causes. In the same manner, the three faculties of the human soul are longing to approach their perfection: the appetitive soul's perfection is in material nourishing, the emotional animal soul's perfection is in victory and leadership and finally the rational soul has its perfection in knowledge and spiritual activities. Although the Brethren believe in the strong influence of the stars on the soul's choice of its object of love, this does not seem to influence their theory of the divine love. Following Neoplatonic thinking, they believe that love is an inborn element in all things but only the elite who are distinguished from the masses recognize the spiritual behind the material and the divine behind the earthly. Divine love is the motivation for the elite to ascend from the material world to join the divine world. They also recognize that the origin of this love is in God and that this love emanates from Him to all things. However, only the rational soul can recognize this love in its perfect form in God and its aim is to attain union with its lover. We shall see in Chapter 3 that Ibn Sinnäs 
Treatise on Love, although it is greatly influenced by this epistle of the Brethren, also reveals other aspects of this love and that he connects it with his own Sufi theory. ${ }^{143}$

\section{Annibilation, fanā'}

The concept of annihilation is a mysterious notion which explains an unimaginable stage of feeling, or rather non-feeling of oneself, of being wholly annihilated in something else. This concept was first elaborated in Islamic mysticism under the influence of Abū Yazīd al-Bisțāmī, who belonged to the Sufi school of al-Junayd. The two Sufi schools which were famous in Baghdād in the ninth century were the school of al-Muhāsibī (d. AD 857) and that of al-Junayd (d. AD 910). Al-Muhāsibī's mysticism rests on two factors: self-examination mubāsabat al-nafs and readiness to suffer in the service of God. Achieving this goal depends on understanding the inward aspect of Islamic belief, which rests on the spirit of obedience and devotion. ${ }^{144}$ Al-Junayd to an extent followed al-Muhāsibī in asserting the importance of obeying God's commandments, ${ }^{145}$ but also followed heterodox doctrines of mystical union. The human soul, for him, originated from God as an idea in His eternal knowledge. He bases this idea on the Qurān 7:171, where God confronts all human souls before their existence and makes a covenant with them. For al-Junayd, this pre-existence of the soul was its original existence as an idea in the divine mind. There are two words, Zaehner explains, which are important for al-Junayd: the word "Be" which, according to the Qur'ān, is the commandment of creation, and the word "union" which brings the soul back to its origin. ${ }^{146}$ However the human soul in its earthly life is inwardly longing to return to its original existence. ${ }^{147}$ In order to do so, the soul has first of all to be one of the elect, who are very few, and to pass through many stages of suffering. In his view, fan $\vec{a}$, annihilation, means "the destruction of the creaturely life of the flesh and participation in the divine." ${ }^{148}$ Zaehner explains that al-Junayd was probably influenced by Indian mysticism in his reflections on the concept of annihilation. In his theory of tawbi $\bar{i}$ there are two kinds of isolation for the soul: the first when God before the existence of the soul makes a covenant with it to confirm His Lordship, when the souls at the same time affirm their testing and suffering in the world. The second isolation is when the soul in its free choice isolates itself from the life of the flesh and experiences a full deification and the annihilation of its earthly life. Al-Junayd also distinguishes between the soul and the nafs. The nafs is the mortal human part which is enabled to act and operate in time, whereas the soul is the immortal side which cannot act independently. Thus only when the nafs is suppressed and melted by obedience to God's commandments, after its purification from its relationship with the flesh, does it return to harmony with the immortal soul and start to experience longing for its return to God. ${ }^{149}$ Zaehner explains that the relationship of union between the immortal soul and God is a secret, as al-Junayd sees it, which only the chosen soul 
experiences with Him. ${ }^{150}$ Al-Junayd admits that he himself never experienced this kind of union.

However, Abū Yazīd al-Bisțāmī (d. AD 875), a student of al-Junayd, significantly developed the idea of annihilation. He was the first one to talk about annihilation in the context of the experience of indwelling. He demonstrated through his experiences, which were reported in many Sufi writings, that God uses the human soul as an instrument to speak through. ${ }^{151}$ Many Sufis report utterances of al-Bisțāmī such as "Glory be to me, how great is my worth." 152 Al-Bisțāmī passed through a stage of total annihilation for ten years; he was reported to say, "I could pass from the No [nothing] (laysa) to the No through the No." ${ }^{153}$ Annihilation for him is a necessary stage in order to reach union with God. However, Zaehner makes a distinction between al-Bisțāmī and other Sufis before him, as being the first to introduce the idea of identification with God's essence rather than with His will. We have shown above that al-Junayd considers the eternal soul to be only an idea in the divine mind and not fully identified with His essence. ${ }^{154}$

Al-Hallāj (d. AD 922), another significant Sufi of this period, considers that annihilation is the stage where the Sufi starts to experience identification with God. He also explains that total self-annihilation is a pre-condition for union with God. However Fakhry maintains that the difference between Hallāj and Bisțāmī seems to be that "Hallāj's union did not result, as it had in the case of al-Bistāmī, in the total destruction or nullification of the self, but rather in its elevation to joyful and intimate communion with the Beloved." 155 This means that in al-Hallāj's opinion the self is not destroyed but rather adapts totally to another role. Thus annihilation and union seem to be two concepts which are inseparable from one another; both aim at full identification with the divine essence, as is reported about al-Hallāj and Bisțāmī. However, we will see that al-Ghazālì considers that annihilation and union aim at full deification with God's presence rather than with His essence.

After the above historical and cultural context of the three thinkers and their three concepts of lutf, 'ishq and fan $\vec{a}$ ', we turn now to examine these thinkers in turn in the three following chapters, followed by an evaluation in Chapter 5. 


\section{2 'Abd al-Jabbār's view of the relationship with God through divine assistance, lutf}

'Abd al-Jabbār's concept of the divine assistance, lutf, is explained in full in his encyclopaedic work al-Mughni (Volume 13). It is the concept which provides the link between God and humans in his theology and unveils God as al-lațîf, the compassionate One, who provides all kinds of guidance. This quality in 'Abd al-Jabbār's theology is closely connected to God's justice, 'adl, which is one of the main principles of the Mu'tazilite theology. Their theology is based on the concept of 'adl in which God is bound to justice, so that He punishes only the sinners and rewards the righteous and therefore provides all humans with freedom of choice. The human ability to choose between good and evil proves God's punishment and reward to be based on justice. God, on His part, provides all kinds of assistance to enable humans to recognize the importance of the search for knowledge of Him and His divine law. Human beings, for their part, are recognized in the Mu'tazilite theology as al-mukalaf, those who are responsible to God for obeying His law. Responsible humans are, however, able to discover who God is and to acquire knowledge about His characteristics only through following a rational system which leads to divine knowledge.

Here, however, 'Abd al-Jabbār seems to acknowledge an important element which was not fully analysed in the Mu'tazilite theology before him. That is, without God's assistance humans can be lost on the way and will never achieve knowledge which is guaranteed to be correct. Thus, 'Abd al-Jabbār not only devotes most of Volume 13 to studying divine assistance, lutf, but we also meet this concept in many other volumes, notably Volume 12, where he explores rational knowledge and considers that God assists humans in all the steps of their journey to knowledge. This assistance guarantees their arrival, as will be explained in the section titled "The rational approach to God." The image of God which 'Abd al-Jabbār has in mind here unveils two of His important characteristics: the first is God's mercy in choosing to create the world and to supply it with a divine system and laws which guarantee its best function. The second is seen in being bound to supply every assistance to mankind in order that humans may have the desire and ability to follow the divine law, which leads to reward. Both characteristics unveil God not only as a just judge, 'ádil, but also as compassionate and merciful, latiff. 
Thus, in order to perceive the concept of the divine assistance and comprehend God's characteristics as described by 'Abd al-Jabbār, we will divide this chapter into three main sections: the first section presents the image of God in 'Abd al-Jabbār's theology and how the Mu tazilites relate attributes to God. Here I shall discuss three main points: (1) what are the essential attributes of God, which give His basic image, (2) how 'Abd al-Jabbār interprets God's activities and (3) what God's main activities are, which unveil His essential character. The aim of these three points is to show how the concept of divine assistance relates to God and why He provides this assistance.

The second section introduces 'Abd al-Jabbār's concept of human beings as responsible for attaining knowledge of God and His divine law. This section is divided into three sub-sections: (1) the first sub-section examines the concept of the human soul and how 'Abd al-Jabbār interprets it. Here it is important to understand how humans function in his theology; (2) the second sub-section summarizes the epistemological theory of 'Abd al-Jabbār in order to show how humans are able to reach knowledge about God and (3) the third sub-section examines a second way of obtaining knowledge about God through revealed messages and shows how this can be related to rational human knowledge. These three sub-sections in the second section of the chapter are designed to provide an understanding of the human need for divine assistance and describe the different kinds of divine assistance which are provided to all humans.

Finally, we come to our objective of unveiling the interaction between God and humans as 'Abd al-Jabbār conceives it, through divine assistance, lutf. In this section we first discuss the concept of divine assistance and how 'Abd al-Jabbār justifies its connection to God as one of His inherent activities. In the two other sections I shall present the concept of divine assistance based on personal contact between God and particular persons. These persons are only able to make their journey of knowledge through the divine assistance which they receive and which enables them to choose to act righteously. These two methods are either warnings, in which God urges individuals to turn from their way and to start reflecting on their life, apprehended as words which are sent to the mind in order to move the intellect to think and reflect, or else sorrows and pain, to warn other individuals that they are ignoring God's path.

The three sections of this chapter not only introduce us to a full comprehension of 'Abd al-Jabbār's understanding of the divine assistance with all its different facets, but also unveil the deepest aspects of his theology.

\section{The main characteristics of God}

The characteristics of God were discussed among many of the theological groups at an early stage of medieval Islamic theology, kalām. All groups agreed that God has two kinds of attributes: those which predicate His essence, sifät al-dhāt, and those which describe His acts, sifät al-fi'll. Yet, many 
theologians differed as to whether we can attribute to God human attributes and, if we can do so, how they are related to Him.

This conflict is connected with the refusal of some theologians and the Muslim philosophers who were strongly influenced by Greek philosophy to give positive attributes to God. Al-Kindī, for example, the first Muslim philosopher, was not willing to confirm certain qualities in God for fear of violating His unity, since attributes mean adding to God different qualities, which would show Him in different and changing states, from being known to creating, hearing, seeing, punishing and so on. However, Muslim theologians including the Mu'tazilites follow the Qur'ān, in considering that God has positive attributes and can be described. Although the Qur'ān predicates to God many human attributes such as those mentioned above, it declares that "nothing is like unto Him." This divine transcendence made many theologians question and reflect on the manner in which the divine essential attribute can be related to God's essence while retaining His transcendence. Again, the difficulty here is how it is possible for God to know or to be able without possessing knowledge or ability? For if He has knowledge and ability then they must be eternal like Him. Muslim theologians discussed all the possibilities: are these qualities eternal notions which have always existed with God? This would mean that God is not the first eternal. Or are they part of His essence? This would mean that since God is (a unitary) One, then all His attributes must be dissolved into one quality. Or are these qualities neither in God nor independent of His essence? But this is in a way absurd. For our present purpose I shall restrict the discussion mainly to the Mu'tazilites' view. ${ }^{1}$

'Abd al-Jabbār and the Mu'tazilites consider that God acts through Himself, li-nafsibi, a concept which caused problems between them and all traditional groups. In order to understand this term we need briefly to examine their theory of God's attributes. 'Abd al-Jabbār belongs to the Mu'tazilite school of Bașra which was founded by Abū al-Hudhayl al-'Allāf (d. AD 841). According to the Bașrian Mu'tazilites, attributes which are predicated of humans or things are the qualities which inhere in a body. Abū al-Hudhayl adopts the theory of atomism which asserts that all things consist of indivisible parts, called jawahir, the plural of jawhar. He considers that each indivisible unit, jawhar, a term which he also applies to the whole body, does not have any qualities in itself except that of existing and occupying space. However, it accepts the qualities which come successively to inhere in it. ${ }^{2}$ These inherent qualities are attributes, which either inhere in one part of the body, such as the quality of seeing which is attributed only to the eyes, or in the whole body, such as the attributes of ability, knowledge, willing and the like. All these attributes are known in kalām cosmology as accidents, a'rạ.$^{3}$ Accidents, according to the Bașrian Mu'tazilites, are immaterial determinants which exist in material bodies and cause their specific quality for a moment or for longer or permanently. ${ }^{4}$ Thus, accident is not merely a rational notion which describes a thing but is a real quality which comes to inhere in 
a material thing and causes change in it; for example, a thing is white because of a white accident which is inherent in it. The existence of these accidents enables the thing to have attributes and qualities. Attributes describe either the nature of the thing or its acts. However, there is also another kind of attributes consisting of those which are an inseparable part of the essence. This last kind is applicable only to God; all other kinds of quality are known as accidents and are created as the body itself is created. In other words, the qualities which God has are different in nature from all other qualities. They are not accidents which come successively to Him but are part of His nature and therefore they do not cause any change in Him, as will be explained below. ${ }^{5}$

After giving this very brief explanation of the Mu'tazilite theory of attribution, we turn to examine 'Abd al-Jabbār's way of relating attributes to God. ${ }^{6}$ God as the first cause of all bodies must be absolutely free from matter and accidents, because if His existence included atoms and accidents $\mathrm{He}$ would have a beginning and an end as all bodies do. Thus, if we prove God is the first cause, then He must be immaterial, with no relation to matter. ${ }^{7}$ This very important element in the nature of God has two main consequences: first, all God's attributes cannot relate to Him as accidents relate to bodies, as explained above. The second is that since God is wholly immaterial then $\mathrm{He}$ is unchangeable, for only matter accepts change in the sense of growing and perishing; this for 'Abd al-Jabbār is a necessary observation. However, because God alone is eternal, the attributes which characterize Him cannot also be eternal notions existing beside God in eternity. Therefore, they must be qualities which are inseparable from His essence. It seems here that 'Abd al-Jabbār is differentiating between two kinds of attributes: accidents with a certain level of materiality such as cause change in bodies and divine attributes which are purely immaterial because they are parts of God's immaterial and unchanging essence. This latter kind, though they do not cause change in the essence of God, are very vague and indefinable as the divine essence itself is. This means that God acts through the qualities of what He is. ${ }^{8}$

Thus, all God's attributes of being able, knowing, living, existing and perceiving subsist in His essence and demonstrate Him as an acting creator. The term "God acts through Himself, li-nafsibi" which 'Abd al-Jabbār uses here, following Abū 'Alī al-Jubbā'̄', his master, refers to the attributes which exist in the divine essence and disclose its qualities. ${ }^{9}$ Since God's essence is eternal, His attributes exist in Him in eternity. An eternal attribute does not only mean to 'Abd al-Jabbār something which has no beginning or end, but also something which includes all possibilities. In contrast to human ability, God's eternal ability can accomplish everything which can exist through aptitude. His knowledge also circumscribes all that can be known, whether existent or non-existent, and His perception perceives all that can be perceived. ${ }^{10}$

Here we see that the concept $l i$-nafsibi is an attempt to attribute different qualities to God without violating the unified nature of His essence. 
With this solution the Ba rian Mu'tazilites could even attribute to God sense perceptions such as seeing, hearing, liking and disliking, however, without the need of bodily mediation. I shall consider this problem next in the context of examining God's essential attributes.

\section{God's attributes of essence}

The discussion of God's attributes, however, is the main subject of the first Mu'tazilite principle, called the principle of the unity of God, tawbìd. Mu'tazilite theologians divide their theology into five principles, under which they explain all theological issues. However, 'Abd al-Jabbār considers that all God's acts which form His relationship to His creatures occur within God's justice, and therefore, he arranges his whole theological system under the two principles of tawbid, the unity of God and His 'adl, justice. ${ }^{11}$ These two principles underpin all the information and arguments about who God is, in tawhìd, and how He relates Himself to the world and to humans, in 'adl.

'Abd al-Jabbār discusses those attributes of God which disclose His unity, tawbi $\bar{\imath}$, in the first three parts of $M u g h n \bar{\imath}$ which are missing; we have to depend here on a summary which is given in Sharb al-Ușül al-Khamsa and al-Mubìt bi-al-Taklīf.

'Abd al-Jabbār regards the act of creation as the event which unveils the main characteristics of God. It demonstrates Him as being able, knowing, living and existent. The first quality is the ability which is implied in the act itself, for whoever acts must have the ability to act which must exist in the agent before performing the act in order to transfer the will to act to its actuality. Since this ability exists in God's essence it is eternal, which means that it is an omnipotent ability. The importance of this point is that God has the capacity to create the world out of nothing because His ability can achieve all the possibilities of bringing things into actuality and existence. The second quality of God is recognized in the perfection of His act of creation, which discloses His wisdom and knowledge. Ability and knowledge must, however, be attributed to a living being who is able to act; thus this being must also be existent. ${ }^{12}$

In addition, each living being has the qualities of being, hearing, seeing, willing, speaking, loving, hating and feeling pain. All these qualities can be also attributed to God, according to 'Abd al-Jabbār, but without the need of bodily instruments. Since a living being must have sense perceptions, God as living also possesses these perceptions. ${ }^{13}$ These attributes caused problems between the two Mu'tazilite schools (the Bașrian and the Baghdādīs); most Bașrians believed that God could have sense perceptions, while the Baghdādīs considered that God cannot possess such perceptions, idräk. The main problem for the Baghdādīs is that if God has sense perceptions then He must have the attributes of feeling pain, mut'alim, and desire, mushtahī. 'Abd al-Jabbār agrees that these latter attributes cannot be applied to God, but he explains that while a human has pain and feelings of love through the means of 
accidents which cause loathing or desiring in the body, God does not perceive these feelings through accidents which come to inhere in any bodily part, but through Himself. Therefore His perceptions and feelings do not influence Him as they do bodies. ${ }^{14}$

Divine perception is probably a part of His eternal knowledge. The real importance of attributing such perceptive attributes to God, however, is to emphasize the fact that $\mathrm{He}$ is able to know individuals in their situation. In contrast, the Muslim philosophers considered that God's knowledge of the changing world must itself have the nature of mutability and therefore would cause a change in His essence. In other words, God must become influenced by world events. Consequently, in their philosophy, God cannot know the individual and the events of their lives. I shall give a more detailed explanation of this concept when exploring the characteristics of God in Ibn Sinnā's philosophy in the next chapter.

Al-Ash 'arī (the father of the Sunnī traditional school), however, points out another problem to do with the essential attributes of the Mu'tazilites. If the attributes of the essence are part of the divine essence, then God's knowledge must be identical both to His ability and to His perception and so on, which means that God in fact cannot have more than one attribute. Al-Ghazālī also considers that the Mu'tazilites' attributes are all dissolved into one attribute, which is knowledge. ${ }^{15}$ In other words, the Mu tazilites do not really attribute to God any attribute except knowledge. 'Abd al-Jabbār rejects this analysis and considers that the essential attributes are not accidents which come to inhere in God but are permanent states, each of which has a judgement and consequences of its own. Ability is attributed to God because of His ability to bring things into existence; His knowledge is observed in the precision and wisdom of His act of creation. God's existence is known through His act of creation, and we know that He is living because He is able, knowing and perceiving; all are the qualities of living things. Thus, for 'Abd al-Jabbār the one simple essence of God has four permanent states and faces, each identifying a different side of God but all part of His divinity, a theory which Abū Hāshim al-Jubāầ, Abd al-Jabbār's master, preached in Baṣra and in Baghdād. ${ }^{16}$

God, nevertheless, has many other attributes which belong to His actions: generosity, mercy, justice and the like. 'Abd al-Jabbār, following Abū al-Hudhayl al-'Allāf and the Bașrian school, considers that these attributes are temporal notions, ma'āni ba $\bar{a} d i t h a$, which exist neither in God's essence nor in any place and which describe all His acts. The concept of temporal attributes which exist nowhere was not accepted by all Mu'tazilites; al-Nazzāam argued that all accidents must inhere in matter, while Abū al-Hudhayl considered that some accidents do exist without location, such as the accident of time and those which describe God's acts. ${ }^{17}$

Consequently, God for 'Abd al-Jabbār is immaterial and unchangeable but nevertheless possesses the Qur'ānic qualities of omnipotence, omniscience, living, existing and perceiving. God perceives all that humans perceive, 
and acknowledges pain and love. We will see in the section titled "Communication through God's duty of assistance, lutf" of this chapter that this feature of God is important for 'Abd al-Jabbār's concept of the divine assistance, lutf, which is provided according to the need of every person. This assumes God's perception of everyone's circumstances and needs. In addition, the eternal knowledge of God signifies His ability to know all events and all human acts. Thus, these attributes of God, according to 'Abd al-Jabbār, demonstrate the ability of God to have direct communication with humans.

After outlining the main features of God's essential attributes, we move to examining the attributes of God's acts and explain the two gracious acts of God: creation and granting the divine law.

\section{'Abd al-Jabbār's understanding of God's activities}

As explained on page 46, 'Abd al-Jabbār asserts that our knowledge of God is dependent on our knowledge of His actions, which are manifested through His creation. The most important activity of God, therefore, is creating, as 'Abd al-Jabbār proves. He says that the existence of bodies indicates the existence of their creator, since their existence entails a creating act. ${ }^{18}$ The creating activities of God are proved in the Mu'tazilite theory of atomism: bodies consist of parts, the smallest of which is the jawhar, the unit which cannot be further divided. (However, al-Nazzām (d. AD 836/845) and other theologians from the Baghdādī school consider that the atom can be infinitely divided, giving rise to the concept of the eternity of the world. ${ }^{19}$ This concept will be examined in Chapter 3.) These parts come together through certain qualities, which come successively to inhere in them. These qualities are ${ }^{20}$ convergence, ijtimā', separation, iftirāq, movement, haraka and immobility, sukün. Convergence makes the parts of the body come together through movement and separation explains its perishing through immobility. However, these four accidents also demonstrate that the body cannot exist eternally, for if it could, it would be impossible to die, which is the consequence of separation; all the body's parts would always remain together, because an eternal being has that eternity within itself which can never perish. ${ }^{21}$ Thus, 'Abd al-Jabbār uses this proof to explain that bodies must be created and cannot be eternal and therefore need a creator, because all things must either be created or eternal; no third option is possible. We can know their creator through His creation; in this section we will examine the nature of God's acts and the different judgments which fall on them. ${ }^{22}$

Since God for 'Abd al-Jabbār is an active Agent, His activity must fall under the criteria of good and evil. But before opening our discussion about God's different activities, it is appropriate first to give a brief explanation of 'Abd al-Jabbār's understanding of the term "acts," al-af'äl, to which he devotes a whole volume - Volume 6 part I, in al-Mughnī. "Abd al-Jabbār analyses the meaning of the word "act," 23 and defines it as: "what comes into existence from someone who has been capable of it." This means that an act 
is completely related to the one who performed it, ta'aluq al-fíl bi-al-fä́$i l$. He divides acts into two kinds (1) those which have an attribute and are performed intentionally and (2) those which are not attributed but performed unintentionally, such as acts performed by sleeping persons or those unconscious of acting, by children or by someone acting under an obligation. ${ }^{24}$ Only intended acts can be judged good or evil. ${ }^{25}$ In judging an act as good or evil, G. F. Hourani points out, 'Abd al-Jabbār adopts an objective view of ethics, which means that judgement may be made of an act without consideration of who performed it; whether God, a prophet or another human being. Hence, the judgement of the act does not depend on whether people or scripture commanded or prohibited it but only on the nature of the act. Wrongdoing and lying, for example, are always recognized as evil, even if they are commanded or performed by a wise person. ${ }^{26}$ The act can be evil because of its inherent nature - lying is evil, for instance, because it is lying. The result or the consequence of the act is an important way of revealing its attributes; an act which is considered evil causes evil. 'Abd al-Jabbār concludes that since all intended acts have to be judged good or evil, then God's acts must fall under the same judgement; the question here is whether God in fact does good or evil?

"Abd al-Jabbār explains that good and evil belong to the same species of "acts" and when God's ability is unlimited, as explained in the section titled "God's attributes of the essence" then He too must be able to do good and evil. Nevertheless, 'Abd al-Jabbār, like all Mu'tazilites, has the full conviction that although God could perform evil, He actually never does so. This conviction is grounded in two main arguments: (1) since God's eternal knowledge circumscribes all that can be known, then He must know the evilness of evil and its consequences, and therefore $\mathrm{He}$ chooses neither to do evil nor to guide any one to it and (2) God is self-sufficient and is not in need of any benefit from an evil act. Therefore, one of the most important qualities and criteria of God's acts is that they are free from evil, both in their content and in their goals. ${ }^{27}$

The importance of the above discussion is, for the Mu'tazilites, to raise an objection against the theologians who considered that God's acts cannot be described in these terms. God, for many traditional theologians, is not obliged to act in a certain way. He could punish the righteous and the children and reward the sinners. Nevertheless, His acts should not be considered evil, they believe, because God is the source of ethics. Acts are known to us as good or evil only because God declares them to be so. Thus traditional theologians consider that God's acts are not classed under human ethics and should not be described as good or evil. Besides describing God's acts as only good, 'Abd al-Jabbār goes through the four following categories in order to identify the kind of acts which are applicable to God:

1 Acts which have no certain purpose and are performed by sleeping or irresponsible persons, or acts under obligation Such acts are judged neither good nor evil and 
therefore this category does not apply to God's acts, because a wise being, for 'Abd al-Jabbār, always acts according to a purpose and a goal.

2 Permissible acts These are good acts which are allowed to all and deserve no blame or praise, such as eating, breathing and the like. God's acts do not come under this category because rational acts are not classed as permissible ones. $^{28}$

3 Recommended and gracious acts These are acts which deserve praise, though omitting them does not deserve blame. Recommended acts, nadb, assist in accomplishing a command or a duty. Gracious acts are mainly those which aim to benefit someone else and are intended to be good. They call for volunteering beyond the bounds of duty. These latter acts are attributed to God and express His gracious acts of creating the world and demonstrating His law, which benefits humans. ${ }^{29}$

4 Obligatory acts These are acts which bring praise for doing them and blame for omitting them. ${ }^{30}$ Obligation can be conferred either because of a command or logical necessity. This last condition is demonstrated in repaying debts, which results from the logical necessity of justice. Some of God's acts, according to 'Abd al-Jabbār, can belong to this last category:

if it is possible for the Exalted to know the obligatoriness of the obligation on himself by his essence, there is nothing to prevent the application of the term wajib, obligatory, to him, although it is impossible to say of Him that there is an oblig[e]r who obliges him. ${ }^{31}$

In other words, the obligations which God follows come as a necessary logical consequence to some other acts which He has performed, such as the duty of assisting humans, which follows from His imposing obligations on them.

Thus, all God's acts fall into the categories of either gracious or obligatory acts. Creation and granting the divine law, taklîf, are gracious acts, while His duty of assistance is the consequence of these two acts. His divine assistance is of two main kinds: "tamkin," which means providing the human body with all the needed abilities, such as seeing, hearing, ability and the will to act, and the like. The second kind of divine assistance falls into what "Abd al-Jabbār calls "lutff," which means making easy, or assisting through sending revealed messages or some specific assistance by giving warnings, khawatitir, or causing pain or disease in order to rouse people to realize the importance of turning towards God, or confirming the correct knowledge through what is known in Mu'tazlite theology as sukün al-nafs, the tranquillity of the soul. All these concepts will be discussed in different sections of this chapter.

After this outline of 'Abd al-Jabbār's understanding of the nature of God's acts, next we examine the concept of the gracious and obligatory kinds of act which God performs. 


\section{The gracious and obligatory acts of God}

'Abd al-Jabbār starts his discussion by confirming that both God's gracious acts and His acts of duty are directed towards goodness ${ }^{32}$; both sorts aim to assist and benefit others and consequently merit praise. ${ }^{33}$ The gracious acts of God, as we have seen, are two: the act of creation and the act of providing the divine law, while His obligatory acts are those which come as a consequence and result of His gracious acts. In this section, however, I shall mainly examine those acts of God which are closely attached to the concept of divine assistance; therefore many of the attributes of God's activity will not be mentioned here. Next I shall summarize 'Abd al-Jabbār's explanation of them.

Creation is for him the most important divine act, which made God known and declared all His essential qualities. Creation, therefore, must have behind it certain purposes and wisdom, and cannot fall into the class of purposeless acts, which may be permissible or useless. ${ }^{34}$ Creating the world, he insists, can neither be the act of someone who does not know what he is doing nor is it useless because God has eternal wisdom. Thus, God cannot act unwisely nor can the act of creation be classed as a permissible act which cannot be attributed to a being. ${ }^{35}$

Thus, creation for 'Abd al-Jabbār demonstrates the grace of God, which has the purpose of benefiting others. Benefits, in his view, are of two kinds: deserved benefit and non-deserved, in the form of gracious gifts. Creation is a benefit which belongs to the latter kind and is offered to all as a divine grace. Deserved benefits are those which are obtained through hard work; in order to provide such rewards God has set certain commands and prohibitions, which guide humans to earn such rewards. To make these deserved rewards known, God has granted a divine law, taklīf, to all humans. This is the second act of God's grace to humans, the granting of the divine law. Performing God's law and following its commandments, however, is a hard task which all humans must undertake in order to deserve the benefits (entering paradise). ${ }^{36}$

These deserved benefits, which are the consequences of adhering to the divine law, play an important role in 'Abd al-Jabbār's theology. ${ }^{37}$ They direct the human interest to the divine law and show the importance of obeying God's commands. God also, according to him, has created humans with certain qualities, all of which have the aim of making human beings rationally responsible, as will be explained in the section titled "The main features of the responsible person, al-Mukallaf."

God's two gracious acts - of creating the world and providing the divine law - discussed above lead to the need for divine assistance. 'Abd al-Jabbār and the Bașrian $\mathrm{Mu}$ 'tazilites consider that in order for people to obey the divine law, they must have assistance, which comes first under the bodily and rational requirements provided for the acquisition of knowledge, and also is granted to those who need it in order to perform their duty. ${ }^{38}$ This assistance, which 'Abd al-Jabbār calls lutf, comes under the heading of acts which God 
performs under logical necessity, and is regarded as a duty which God must undertake. Obligatory acts are not only those which are obliged by an obligoer but also those which entail logical necessity as a duty, such as the repayment of debts. This inner necessity aims either to benefit oneself or to benefit others, as outlined above. ${ }^{39}$ Thus, we apply the term obligatory to God's acts, 'Abd al-Jabbār explains, not because of any commandment nor because He wants to benefit Himself but rather because of the logical necessity of assisting others. 'Abd al-Jabbār argues here that when God imposes the divine law on humans and motivates them to obey it through rewards and punishments, then He has a duty or is responsible to assist us to obey it. ${ }^{40}$ The necessity here lies in His knowledge that humans are not able to perform His law without this assistance. All God's acts which come under the notion of assistance seem here to be acts which He must undertake such as providing necessary knowledge, sending prophets, guiding the needy towards His path and causing pain to some so that they may repent and direct their life to divine knowledge. In the study of the characteristics of humans, we describe many sides of divine assistance; moreover, section three of this chapter will be devoted to revealing the importance and implications of this concept.

The theology of the Mu'tazilites, however, was severely criticized by modern and medieval theologians because of their image of God as One who is imprisoned in His own wisdom. Al-Ghazālī in his work al-Iqtisād shows that this kind of theology reduces the possibilities of God's grace and makes Him act according to the force of logic. For example, prophecy is not seen as an act of grace but as something which God must grant and a duty which $\mathrm{He}$ could be blamed for not carrying out. ${ }^{41}$ However, 'Abd al-Jabbār is not reducing God's grace here but rather showing that it has certain consequences. God, for him, takes the responsibility for embodying His grace in certain acts of assistance, in order for it to become complete.

To conclude, in this section of the chapter we have examined 'Abd al-Jabbār's image of God and the possibility of describing His essential nature. It has become clear that although he described God in highly philosophical and abstract terms, he attributed to Him the kind of perceptions which humans possess. However, the transcendence of God is safeguarded in that he sees all God's attributes as functioning from within His essence, while humans' attributes come from outside their essence. God acts according to divine wisdom and therefore all His acts have purposes, either demonstrating divine grace or being bound to the wisdom of accomplishing His divine plan for assisting humans to achieve what He sees as best for them. Consequently, God, in 'Abd al-Jabbār's theology, is pictured as a wise being who is immaterial and unchangeable, but able to perceive human feelings. In this theology, God is bound to act wisely and according to a certain logical rational plan; it is not possible for Him to violate these measures or to ignore them. 'Abd al-Jabbār's theology is very much influenced by an image of God which strongly supported the Mu'tazilite rational interpretation of religion and 
would become an integral part of their system. These features are the basis of 'Abd al-Jabbār's concept of the divine assistance, which is connected to God's sense of duty to assist humanity to best realize its potential and to earn the heavenly rewards.

After this account of the features of God and the different ways in which He acts, we turn to examine the features of humans and their possibility of obtaining a knowledge of God. This, together with the above examination of God's characteristics, may make it easier to understand the concept of God's assistance, which will be explored in the section titled "Communication through God's duty of assistance, lutf" of this chapter.

\section{Human nature and the different ways of knowledge}

Humans and their ethical behaviour play an important part in 'Abd al-Jabbār's theology, although he was not preoccupied by studying the human soul or intellect. However, he reflects on the nature of the human in the context of his study of the divine law, taklîf, in Mughni Volume 11. In this section, therefore, we attempt a brief study of his concept of al-Mukallaf, the responsible, as mankind is called in his theology. Further we discuss the two ways by which humans are able to reach knowledge about God, the rational and the revealed, in two later sections.

\section{The main features of the responsible person, al-Mukallaf}

'Abd al-Jabbār, following the Bașrian Mu'tazilite theology, adopted the theory of Atomism in explaining the nature of man. Like all other creatures, man functions through the different accidents which come successively to inhere in him. According to 'Abd al-Jabbār, humans, like all created things, consist of indivisible parts and accidents. Many theologians of this period refer to these indivisible parts (atoms) as a substance, jawhar, but 'Abd al-Jabbār uses the word substance also, to refer to the body. ${ }^{42}$ Substance, however, can consist of more than one atom; it also, he points out, explains the element of permanence, which relates things to their species and genus. ${ }^{43}$ Accidents, in contrast, exist only in a substance or atom and express the elements of change which occur to the substance.

Accidents are of two kinds, created and acquired. Life, perception, ability and perishing come only from God, while knowledge, ignorance, doubt, conviction and the like, are acquired by each person. ${ }^{44}$ Some accidents are acquired through another agent; knowledge, for example, can be learned from others or pain can be caused by another. Thus, all activities of humans are explained as inhering from the effects of different accidents at different times. $^{45}$

The human soul and intellect are not considered, in 'Abd al-Jabbār's theology, to be immaterial elements inhering in the body, as Muslim philosophers generally think of them. In contrast, according to him the word soul, "rū $b$ " 
in Arabic comes from riyah, wind, while the term nafs, which also designates the soul, comes from nafas, the air we breathe. This, therefore, refers to the air which we inhale and which causes life to continue. ${ }^{46}$ 'Abd al-Jabbār argues in al-Mughñ̄ 11 against the theologians of the Baghdādī Mu'tazilite school such as Hishām Ibn al-Hakam (d. AD 795/815), Bishr Ibn al-Mu'tamir (d. AD 825/840) and al-Naz̧āàm (d. AD 836/845) who consider that behind each visible person exists an invisible soul which is the power initiating all activities. The soul is the eternal element, they believe, which remains after the death of the body; it is the determinant, $m a^{\prime} n \bar{a}$, which causes the actuality of the body. ${ }^{47}$

The arguments of 'Abd al-Jabbār against the Baghdādī theologians run as follows: first of all, whatever cannot be proved by spontaneous grasping nor absorbed by the methods of acquisition and reflection cannot be known. He presents Abū Hāshim al-Jubbā'̄ìs argument that if the soul were to inhere in all parts of the body, then it would be like a garment we wear, which we experience immediately. This, however, is not the case with the soul. 'Abd al-Jabbār also asks if we can prove the existence of the invisible soul, supposing it to be other than the visible body, when all its activities are identical with the activity of the visible person. ${ }^{48}$ In this part of the argument 'Abd al-Jabbār attempts to demonstrate the difficulty of acquiring knowledge of the soul and identifying its activity if it is separated from the body.

He also argues against al-Nazzām, who considers that the soul is a substance which has knowledge, life and ability in itself, li-dhātihā. Al-Nazzāam also maintains that the soul is the life which flows in the body and causes its activity. 'Abd al-Jabbār argues that if the soul were a substance in which knowledge and ability inhere, then it would not be possible for these to inhere in the body, because substances cannot inhere in other substances; however, if it were an accident, then it would not accept other accidents such as knowledge and ability because accidents do not inhere in each other. In other words if the soul were an accident, it would only have one quality. Also the possibility that the soul could initiate activity per se is impossible, in 'Abd al-Jabbār's opinion, for the only being who acts through Himself is God. Activities which are initiated through the essence, sifät nafsiyya, however, would not be restricted by any limitations; this would mean that people would be omniscient and become omnipotent, but humans are neither. ${ }^{49}$ 'Abd al-Jabbar is trying to make clear here that humans have no divine element inside them which initiates all their activity, as philosophers and Sufis believed.

From the discussion above, it seems that 'Abd al-Jabbār is emphasizing here the unity of the human being and is fighting against the duality of soul and body which was spread among some Mu'tazilites in Baghdād. This concept of the duality of body and soul attributes all human activities to the soul; the body remains the passive instrument which the soul uses as a window to the material world. Traditional theologians and the Mu'tazilites probably adopted atomism because it supported only one duality: that between God 
and the world. Nothing acts by its own power except God; He continually creates the accidents which provide the world with the power to act. In contrast, most philosophers and Sufis considered that the soul is a divine power inhering in the body and initiating all its activities. 'Abd al-Jabbār considers this theory heretical because whatever is divine cannot inhere in a material body; hence human activities must be interpreted in a different light. If humans do not have an immaterial soul inside them, then as a logical consequence they must function through powers which are given to them from God.

At all events 'Abd al-Jabbār considers that humans are created in order to receive different benefits, the highest of which are the deserved ones. For God to bestow this kind of benefit, He grants humans the divine law, which reveals the importance of reward and punishment. Human beings for 'Abd al-Jabbār have the attribute of being responsible, mukallaf; they are created with certain qualities which enable them to fulfil the divine law. These qualities are implanted in them and known among Mu'tazilites as tamkin. 'Abd al-Jabbār counts these qualities in al-Mughni 11 as follows:

1 The first quality is the desire to act, which is the first attribute created in the body and that motivates humans to act and recognize the importance of obtaining benefits. ${ }^{50}$

2 The second quality is ability, which enables someone to act; this allows $\mathrm{him} / \mathrm{her}$ either to perform an act or refrain from it. It is created in a person long before the act to enable him/her to choose between different possibilities of action. Thus, free will and the ability to perform an act or refrain are conditions which humans must have in order to be rationally responsible for achieving God's law, taklīf.

3 Humans are provided with rational necessary information, 'aql. 'Aql for "Abd al-Jabbār is certain basic and immediate knowledge which is considered to be the basis on which rational knowledge is built. This basic knowledge comes from God and identifies the person as rationally mature and qualified to act rationally. ${ }^{51}$ The next section will provide more details of this concept.

'Abd al-Jabbār shows here that humans are created with certain qualities which indicate a purpose behind their creation; that is, they have the quality of being responsible, mukallafün, and commanded to fulfil certain duties. Human activities, therefore, must be concentrated on the divine law, takliff, which is mainly done by obtaining rational and revealed knowledge. Having examined the main attributes of human beings, we concentrate now on the ways which lead them to knowledge about God and His divine law. We look next at how humans can obtain such knowledge.

\section{The rational approach to God}

Humans, as responsible beings in 'Abd al-Jabbār's theology, are required to search for knowledge about the world, about its creator and about the ways in which they can be rewarded. The only way to gain rewards, in the view of 'Abd 
al-Jabbār and the Mu'tazilites is by acquiring the knowledge of God and of the duties to be undertaken. Knowledge, however, is divided into two main areas: knowledge which humans obtain through their own learning and searching and knowledge which is revealed through religious messages. In both, humans need to reflect and to follow a rational system which prevents error. In this section, therefore, we will explore the concept of human rational knowledge, nazar, and the next will examine 'Abd al-Jabbār's understanding of revealed knowledge and how human beings can interpret it. The significance of this study here is to explore human beings' need of God's assistance in both branches of knowledge.

'Abd al-Jabbār presents rational knowledge as some connection between a subject and an object. He describes knowledge as

of the genus of belief (itiqād) when it is related to the object as it is, and occurs in conditions of mental repose (sukūn al-nafs), it is knowledge. When it is related to the object as it is not, it is ignorance. When it is related to it in a way that confirms it but not in a state of mental repose, it is neither knowledge nor ignorance. ${ }^{52}$

From this passage we recognize that knowledge, for 'Abd al-Jabbār, depends on two bases, one objective, the other subjective. The objective is knowing, observing or reflecting on a thing as it exists in reality, while the subjective is the state of repose in the mind which must result from this reflection. Here we observe that knowledge, for him, depends on the relationship which exists between the subject (the person) and the object (the thing). This relationship results in a certain conviction about the thing which causes knowledge of it. This conviction, in return, brings tranquillity to the mind. However, the connection between the subject and the object could be a sensible perception of the object, or it could also be what is obvious to the mind, such as seeing a thing and realizing that this thing cannot be in two places simultaneously. But it might also be asking questions about the object, attempting to understand its qualities or its relationship to other things. ${ }^{53}$ Thus, this relation between the subject and the object happens through two related sorts of knowledge: the sort acquired by necessary and immediate knowledge of the thing's qualities, and the sort acquired through reflection and inquiry about the thing in its relations to other things. Hence, knowledge is rooted in two ways, as facts which are revealed to the mind immediately and known as necessarily correct, for example, all obvious information which is known without reflection, and as known through reflection and learning by different methods. Humans need both ways in order to acquire correct knowledge about the world with its creator. ${ }^{54}$ Next, we shall explore the importance of both kinds and what this will reveal about the nature of knowledge as 'Abd al-Jabbār sees it.

\section{Necessary knowledge}

Knowledge which is necessarily known means to 'Abd al-Jabbār what all rational responsible people accept immediately. We will use here both terms, 
"necessary" and "immediate," in order to render the meaning of darūr $\bar{z}$, in the different places where "Abd al-Jabbār uses it in relation to this knowledge. ${ }^{55}$ It comes, according to 'Abd al-Jabbār, from reliable information which is obtained through the perceptions of the senses, obvious ideas, or simply finding ourselves wajada nafsabu, having certain information without identifying its source. Thus, necessary knowledge is obtainable through (1) perception, idräk and (2) intuition, 'aql.

1 Idräk is normally used by 'Abd al-Jabbār to mean the perception of the senses, or perception through an instrument. This kind of perception perceives the thing via a certain attribute, for example, we recognize a thing as black or small or moving. So idrāk does not go deeper to know whether this thing, for example, exists autonomously or is created or whether it is good or evil. He also means by it the perception of what is situated in a given place, idrak al-mah, $l$ and therefore he considers it the knowledge of the particular. ${ }^{56}$

2 The second way of obtaining this reliable knowledge is through 'aql 'Abd al-Jabbār devotes a long chapter in al-Mughnī 11 to discussing the meaning of the word 'aql. For him 'aql does not simply mean intellect or rationality; it is rather a certain knowledge which is known necessarily and immediately and it qualifies the person as someone rationally responsible ${ }^{57}$ who is able to reflect and acquire knowledge. ${ }^{58}$ ' $A q l$ here is not also used to refer to a certain place or organ or substance in the body, as it is among the Arab philosophers who figure in Chapter 3, which is on Ibn Sīnā. 'Abd al-Jabbār argues here that if 'aql were a substance, here meaning jawhar or atom, which is passive and accepts any accident, it would accept all kinds of accidents, and this would mean that the substance 'aql can accept knowledge and ignorance. In this case, we cannot attribute maturity to everyone who possesses 'aql, for it can mean both knowledge and ignorance. 59 "Abd al-Jabbār also argues against the concept of 'aql as an independent power existing in the body and functioning independently. He explains that if by "power" is meant "the ability to achieve certain knowledge," then there must be people who are credited with rational maturity, 'áqil, only because they possess this ability, but who lack knowledge, because ability must precede the act of knowing. ${ }^{60}$

In conclusion, 'aql for 'Abd al-Jabbār is certain knowledge which exists in most people and enables them to reflect and acquire science. His reference to it as 'aql should be considered here as conventional usage, which, as he explains, calls all mature persons rational, 'uqala'. ${ }^{61}$

However, the knowledge which is referred to here as 'aql is of two kinds: (1) self-evident knowledge such as that one thing cannot exist in two places or that the whole is greater than the part and (2) general ethical rules. 'Abd al-Jabbār and most Mu'tazilites believe that there are many ethical rules which are known to us immediately, for example, that lying or wrongdoing is evil. However, details about the acts which come under wrongdoing 
or lying can only be acquired. In addition, other acts, such as thanking benefactors or paying back debts, are seen by all rational responsible people immediately as good and matters of duty. ${ }^{62}$ It seems here that these kinds of ethical rules are acquired through immediate intuition which each person can possess, while self-evident knowledge and knowledge through perception are created in us. Although it seems that the knowledge of the ethical rules depends on subjective methods, Hourani explains that 'Abd al-Jabbār considers it to be drawn somehow from experience. ${ }^{63}$ Hourani here wishes to assert the objectivity of 'Abd al-Jabbār, but although many of the necessary ethical rules here could be absorbed through different experiences, nevertheless, 'Abd al-Jabbār is referring here to ideas which are perceivable immediately as good or evil. ${ }^{64}$ Lying, for example, could be judged in many situations as good if it enables people to escape unjust judgements. But 'Abd al-Jabbār here says clearly that no matter what experience we have of lying, it is known to us immediately as evil. He also here asserts the reliability of this knowledge which goes beyond different individual experiences and ensures that everyone has a judgement which is correct and reliable; this seems here to be guaranteed by God, who reveals these ideas to the mind. Thus, it is not experience which judges the act but an immediate kind of knowledge, open to all, which he believes to be possessed by all rational mature people. This can be understood as a kind of intuition, but probably in a simple form, for it is open to all and it marks the person as mature.

However, 'Abd al-Jabbār faced severe criticism from his Ash'arite opponents, who rejected the universal acknowledgement that this knowledge existed. For them, ethical rules were mainly known through revelation. ${ }^{65}$ 'Abd al-Jabbār insists that the denial of this truth here cannot lie in the fact that wrongdoing is evil but on how we decide that a certain act comes under wrongdoing. This can mainly be known through rational reflection. ${ }^{66}$

We can observe that necessary knowledge reveals important points in the theology of 'Abd al-Jabbār. The first point is that we possess reliable information about the world and we never start our inquiry from nothing. The second important point is that there are universal truths which all should agree on and the guarantee that this is true is that it comes from God. In addition, 'Abd al-Jabbār considers that a great or a basic part of the rational taklif $\mathrm{f}$ is revealed to the mind through the immediate apprehension of the ethical rules.

\section{Reflection, naẓar}

Acquired knowledge, in contrast, is the knowledge to enquire about concepts which are not accepted as self-evident, but have a necessary basis, așl darūriz, needing further support through proof and argumentation. This is a very important kind of knowledge, 'Abd al-Jabbār maintains, for it is the knowledge which one uses to prove the existence of God and His attributes. He explains in Sharb that the existence of God cannot be proved by necessary 
knowledge because He cannot be perceived by the senses and His existence is not obvious to the mind. ${ }^{67}$ The existence of God also cannot be proved by revelation, he explains, because revelation can only be accepted when it is proved to be from God which means we have first to prove the existence of God and His qualities, such as assistance, which explain why God chooses to send revelatory messages. ${ }^{68}$ Therefore, people depend on acquired knowledge for their knowledge of God, with His attributes and His obligations.

The way to obtain acquired knowledge, for 'Abd al-Jabbār, is through inquiry or reflection, nazar ${ }^{69}$ He describes the generation of knowledge by means of reflection as an intermediate position between two states in a person: the first is being not convinced, ghayr mu 'taqid, and the next is being convinced, $m u$ 'taqid, or finding oneself knowing. ${ }^{70}$ These two positions recall Aristotle's two ranks of the human intellect, the material intellect, when the intellect has no information, and the actual intellect, when it possesses knowledge. These two states are known to us immediately as are all other states of being, thinking, doubting and the like. Reflection transfers the person from the first state to the second and when the second state (being convinced) is followed by tranquillity of mind, sukün al-nafs, a feeling of peace about the conviction, then we are assured that our conviction about the object is correct. ${ }^{71}$

Reflection first of all depends on identifying the object, which 'Abd al-Jabbār calls the object of reflection or, in a religious context, dalīl, indication. It is an indication which is intentionally placed to indicate something else and this he sees as the basis for religious enquiry. ${ }^{72}$ Reflection leads back from the indication to the indicated thing or person. Hence, it is very important to identify the relationship between the indication and the indicated in order to reach the latter. Two conditions should be fulfilled: the indication should be placed intentionally and should have a certain connection to the indicated; for example, the Qur'ān indicates the prophecy of Muhammad. ${ }^{73}$ Thus, the indication must be apparent to us necessarily, but what it indicates must be acquired and the indicated thing or person must have a clear relationship to this indication; for example, bodies indicate the existence of the one who caused their existence. ${ }^{74}$

\section{The tranquillity of the soul as a condition for knowledge}

However, the decisive element for 'Abd al-Jabbār in examining the correctness of knowledge is whether this knowledge produces tranquillity of mind and soul, sukün al-nafs. Al-nafs here means probably the whole person or what is difficult to locate at any particular place in a person, though, as Peters points out, 'Abd al-Jabbār does not believe in the existence of a soul or a nafs inside us which produces our activity. However, 'Abd al-Jabbār and the Mu'tazilites felt confident in using the word nafs here to render the meaning of a sense of peace about one's conviction. He might mean here repose of mind, as Hourani calls it, or tranquillity of soul, as Peters translates it. 
Immobility, sukün, here means, as 'Abd al-Jabbār explains in Sharh, that the conviction about certain problems has reached a level where the enquirer is assured that no more investigation is needed or that his/her research has come to an end; he compares it with the Arabic idiom "the immobility of anger." 75 The criterion for testing tranquillity of soul is mainly the correspondence of the conviction to the reality which it indicates. When the conviction does not correspond with reality, it should be considered ignorance. When it expresses reality but lacks tranquillity of soul it denotes doubt. ${ }^{76}$ These cases demonstrate that 'Abd al-Jabbār is not addressing here a subjective notion which wholly depends on people and their feelings but is the result of objective rational research. 'Abd al-Jabbār explains in al-Mughnz that someone who has sukün al-nafs differs from others who might have the same conviction but lack tranquillity of soul and mind for some reason. This reason leads to the state of sukün al-nafs and probably belongs to the process through which the knowledge is obtained. ${ }^{77}$ Thus, it is possible here to relate the tranquillity of the soul more to the process of rationality than to its resulting conviction, because others can have the same knowledge but do not have the same peace, for example, the muqalid, people who follow other people's opinions or those who reached this knowledge as a consequence of mere chance. ${ }^{78}$ However, the crucial question here is why this knowledge (or its rational methods) produces tranquillity of soul. In answering this, 'Abd al-Jabbār discloses the real nature of this concept. He explains that the assurance of sukün al-nafs is similar to our conviction that wrongdoing, $z u l m$, is evil. ${ }^{79}$ This means that sukun al-nafs happens in an immediate manner without our realizing that it has happened: "the tranquillity of the person's soul to what he knows does not happen through perception but through self-evidence bi-badīhat al-'aql in the same way we judge that wrongdoing is evil." ${ }^{80}$ Sukün al-nafs must give people, he asserts, the same kind of assurance and guarantee which they receive from the immediate necessary knowledge of proving that Zayd is at home on the basis of seeing him there. ${ }^{81}$ Thus, "Abd al-Jabbār here is comparing the experience of sukun al-nafs with the assurance of immediate knowledge, which suggests that he considers that both have the same divine source. Hence, we infer that 'Abd al-Jabbār considers sukūn al-nafs, although connected with the method of reaching a state of conviction, to be granted by God in order to assure people that their conviction is justified and therefore he considered it divine assistance, lutf. The importance of the above discussion is in showing that sukün al-nafs provides one of the important aspects of divine assistance, lutf, which is granted to whoever searches sincerely for knowledge. We have seen here in this section various kinds of divine assistance which are received through the search for knowledge. First of all God creates in humans the desire and ability to act, then He creates in them the necessary information which they need in their search for understanding their surroundings and their creator. God also here grants the peace of mind, sukin al-nafs, which assures them of the correctness of their conviction. 
The importance of rational knowledge for "Abd al-Jabbār here is that it demonstrates the human need for rational reflection in order to first acquire knowledge of God and His attributes. After the enquirer gains such knowledge, God confirms it and expands it through sending revealed messages which are also considered part of His assistance, lutf, and form the subject of our next section.

\section{The role of revealed knowledge}

In the first 14 volumes of al-Mughnī 'Abd al-Jabbār discusses the different theological theories which we can grasp through our rational knowledge. ${ }^{82}$ After exploring the rational methods, "Abd al-Jabbār turns in al-Mughni 15-20 to examine the concept of revealed messages, prophecy, the inimitability of the Qur'ān and other theological issues which can be made known to us or are mainly drawn from revelation. Here, however, he uses the same rational methods for examining each revealed issue in order to demonstrate its reliability and to interpret its importance in helping us to fulfil our rational obligations. This arrangement of al-Mughnz demonstrates that 'Abd al-Jabbār sees revealed knowledge as a branch or confirmation of rational knowledge. $\mathrm{He}$ argues here that we can only accept revealed knowledge after proving that it was sent to us by God. Thus, we have first to prove the existence of God and examine those different divine attributes which present the act of sending revealed messages as God's assistance, as discussed on page 59. This is the content of al-Mughni 1-15.

'Abd al-Jabbār explains in al-Mughñ̄ 7 and in al-Mubịt that the Qur'ān is the evidence that God is speaking; His speech is made known to us through these revealed messages. This divine speech clearly specifies God's commands and prohibitions and is considered here as lutf and assistance which is provided to all for their clear and direct guidance. God's speech, however, like all kinds of speech, is created in order to show what God wishes to communicate to humans. Thus, the difference between the Qur'ān and the eternal knowledge of God is that the Qur'ān expresses only what God wishes to communicate out of His knowledge. The problem of the createdness of the Qur'àn provoked a protracted struggle between the Mu'tazilites and all the traditionalists, who regarded the Qur'ann as the eternal word of God. 'Abd al-Jabbār mounts many arguments in Sharb and devotes Mughnī 7 to arguments against the concept of the eternity of the Qur'ān, some of which run as follows: if God's speech were eternal and infinite then it would include all kinds of speech, both good and evil, because an eternal attribute includes all possibilities, such as God's ability which achieves everything that can be created. Eternal speech would be no use to us, he insists, because it would not specify what the speaker wishes to communicate. ${ }^{83}$ But since we know that God's speech is only concerned with the commandments which lead to goodness and it reveals only what God wishes to reveal from His eternal knowledge, then His speech cannot be eternal and therefore it is temporal. ${ }^{84}$ However, 
although this problem lasted many centuries, the Mu'tazilites, like the Ash 'arites, believed firmly in the inimitability of the Qur'ān and its revelation of God's speech. Nevertheless, the createdness of the Qur'ann shows that the words in themselves are not eternal and their function is to present what God wishes to reveal and communicate; this, therefore, opens more opportunities for interpretation, $t a^{\prime} w \bar{\imath} l^{85}$

The content of revealed knowledge, as of all kinds of knowledge, must have a rational ground which proves its claims, because a commandment in the eyes of 'Abd al-Jabbār, is obligatory not only because it is from God but because of its content. Thus, revealed knowledge must follow the same fundamental basis of rational knowledge. But the question here is whether we actually need revealed knowledge? 'Abd al-Jabbār's task here is, thus, to prove that a revealed message, though it is accepted rationally, contains things which our rational knowledge cannot reach. ${ }^{86} \mathrm{He}$ argues that the importance of revealed knowledge lies in the detailed information which it gives about some acts; it is concerned with the details of performing certain acts and refraining from others, al-fi'l wa al-tark. These commandments and prohibitions might not be accessible through immediate intuition or reflection. Our minds, for example, can only insist that we should thank and worship God but cannot provide the detail of this worship. ${ }^{87} \mathrm{He}$ also explains that acquired knowledge can only extend to things which can be known rationally, but other kinds of information must be gained through other methods, including such details as allowing the slaughter of animal for the sake of human needs, or details of future events, 'ilm al-ghayb, such as the nature of angels or paradise and hell or the nature of reward and punishment. ${ }^{88}$

Revealed knowledge discloses also the characteristics of some specific acts, including motivating, af'al d da' $i y a$, which stimulates the performance of rational obligations. Prayers which motivate good actions and the prohibition against alcohol, for example, are revealed in the Qur'ān as helping avoid evil deeds; consequently, they aid the fulfilment of the divine law. ${ }^{89}$ Hourani explains that the motivating acts uncover the depth of revealed knowledge in demonstrating the characteristics of many acts which, though they can be known rationally, can mainly be known, in their full implications, only to the creator. $^{90}$

Revealed knowledge in its totality is considered here as divine assistance, lutf, which is granted to all and functions as a part of God's plan for humanity. God, however, must provide prophecy because if this revealed information could only be known through revelation then God would certainly send prophets. God must grant the people this kind of knowledge to allow them to reach a full comprehension of His will and be able to perform their religious and rational duties.

As a result both rational and revealed knowledge are obligatory. Their main goal is to permit obedience to the divine law and the earning of deserved reward. Rational knowledge has the main task of exploring the first cause of the world and the reasons behind creation. Having laid down this 
basis, rational reflection leads people further to discover the divine law which can be known through rational means from the necessary knowledge which is granted by God. God also assists humans to discover some commandments of the divine law which cannot be known through rational means and discloses the characteristics of some acts by sending revealed messages which assist us to perform our duties and confirm the reliability of the rational obligations. Both rational and revealed knowledge function very closely together in such a way that the absence of one of them causes us either to misunderstand and misinterpret revelation or to go without the assistance which makes it possible (easier) to perform our rational obligations. Hourani points out here that, for the Mu'tazilites, God's ethical prescriptions for humanity do not go beyond what they can rationally apprehend, thus disclosing the harmony between reason and revelation. ${ }^{91}$ The theology of 'Abd al-Jabbār and the Mu'tazilites, then, is based on the reliability of both sources of knowledge, the revealed and the rational, which are both guaranteed by God.

After explaining the communication between God and humans through rational and revealed knowledge, we next examine a further form of relationship that built upon divine assistance, lutf.

\section{Communication through God's duty of assistance, lutf}

The divine assistance, lutf, is a concept under which 'Abd al-Jabbār reveals God's character as al-lattī $f^{92}$ the one whose essence is to assist and benefit others. In the section titled "Human nature and the different ways of knowledge", we have seen various purposes for divine assistance: to provide the desire and ability to act precisely, to grant necessary and immediate knowledge and to bestow tranquillity of soul. God also grants revelation to all humanity in order to unveil His specific commands and prohibitions and the details which the mind is not able to attain on its own merits. All these are different kinds of assistance which 'Abd al-Jabbār explores in the context of rational and revealed knowledge.

The assistance of God, according to 'Abd al-Jabbār, is granted in two forms:

1 Tamkin This refers to creating humans with certain qualities which enable them to acquire and discharge the obligation of the rational takliff, as outlined on page 54.

2 Lutf This refers to two kinds of lutf, the first is the assistance which is granted to all and has the function of simplifying difficult commandments and motivating us to obey them; this includes assistance by sending prophets or assistance in all the steps of achieving knowledge, as explained in the section titled "Human nature and the different ways of knowledge."

The second kind refers to the assistance which is directed to specific persons whose need God knows. This kind of assistance is granted in the form of warnings through fears which lead people to reflect or pain which urges 
them to repent. In Mughnī 13 'Abd al-Jabbār devotes a long passage to the concept of lutf and unveils its scope. In this section of the chapter we shall concentrate on this other aspect of God's assistance, which is bestowed on specific people whose exact need God knows and which will turn them to repentance.

Thus, we come here to an important part of 'Abd al-Jabbār's theology, a part which demonstrates his deep belief that God also acts on a personal and intimate level. Here we may understand that God, as 'Abd al-Jabbār mentions in the section titled "The main characteristics of God," is able to know the situation of each person through His divine perception. I shall examine here two main concepts: assistance through warnings, khawațir, which God creates in some people's minds and through pain and suffering which are caused to others so that they may repent and concentrate on the importance of knowledge. This reveals God as the one who assists al-latinf $f$ on the personal level and in this way builds a strong bridge for mankind. But first it is important to examine his belief in the obligatory nature of divine assistance and disclose the reasons behind this belief.

\section{Obligatory nature of divine assistance}

In Sharb 'Abd al-Jabbār presents the argument of Bishr Ibn al-Mu'tamir, a member of the Baghdādī Mu'tazilites, against regarding lutf as a necessity upon God:

[I]f lutf were obligatory on God, there would be no transgressor in the world. Because it is possible for God to bestow alțäf on every obligatee... Since we find among the obligatees some who disobey God and some who obey Him, it becomes evident to us this lutf is not obligatory on God. ${ }^{93}$

In other words, if divine assistance is obligatory then God would have to assist every person to act righteously and consequently every one should become a believer, which seems to him absurd. But 'Abd al-Jabbār considers that lutf is not an aspect of God's ability to grant assistance to every obligatee, but rather is an aspect of His knowledge of human nature. Among people, he explains: "there are some who if God performs certain acts on them, will choose, at this moment, [to carry out] the obligatory act and avoid the evil one." Yet God also knows that there exist some who "will do the opposite, so that if God performs His acts on them, they, at this moment, will not choose [to carry out] the obligatory act." 14

However, it seems here that 'Abd al-Jabbār is ignoring the main point of Bishr's protest above, which was why should this assistance be an obligation upon God? However, in al-Mughni 13 he mentions two reasons for the necessity of this act. The first is related to the nature of God. The gracious acts of 
creation and granting of takliff reveal God as al-mun ' im, the benefactor whose nature is to benefit and assist others. Yet the assistance which leads to achieving taklif $f$ is seen by God as necessary because it cannot be omitted, while creation and granting the divine law are acts of grace which were voluntary. ${ }^{95}$ The second reason belongs to 'Abd al-Jabbār's concept that all God's acts after His imposing the divine law, takliff, are assisting acts which function as the conditions for obeying it. Without this assistance, tamkin and lutf, 'Abd al-Jabbār asserts, human beings could not obey the divine law and therefore the assistance is not produced by God's grace, since omitting it would make us unable to carry out our obligations to God. ${ }^{96}$

'Abd al-Jabbār is making here a clear distinction between grace and duty by showing that grace is a voluntary act which may be omitted, while duty is a necessary act which cannot be omitted. On the basis of this definition, God's acts which can be omitted are acts of grace, whereas the ones which are vital and necessary cannot be omitted and must be considered as duty, as a logical consequence. Thus, 'Abd al-Jabbār does not declare God here as obliged, in the sense of being subject to someone who obliges Him to do a certain act; simply, there are certain acts which are considered as acts of grace while others are obligatory.

'Abd al-Jabbār here also argues against Aṣhāb al-Aṣlah, a group of theologians probably belonging to the Baghdādi Mu'tazilites, ${ }^{, 7}$ who consider that all God's activities must be directed only to the best possible ways of benefiting others, al-aslah, which means that all His activities are directed to a necessity and they are all duties. ${ }^{98} \mathrm{He}$ argues here that a duty must have a logical reason, which justifies its obligatoriness. ${ }^{99}$ God's creation of the world and His grace in disclosing the divine law, takli $f$, are good acts, but they have no logical necessity, for God would not deserve blame for omitting them. Both these acts are pure grace; no logical reason obliged God to perform them. Both these gracious acts must precede the divine assistance, which is the result of imposing the divine law. When God imposes the divine law on humans and motivates them to perform it through rewards and punishments, then He has a duty to assist us to obey it. ${ }^{100}$ The necessity here lies in His knowledge that humans are not able to perform His law without this assistance.

The question which is mainly asked in the above discussion is why should God be bound to assist humans? 'Abd al-Jabbār sees that the necessity of assisting humans lies in God's wisdom and knowledge of people's incapacity to keep the divine law by their own power. Thus, if He rewards humans on the basis of their obedience to His laws, He must provide the necessary assistance to enable them to choose right actions. It seems that the $\mathrm{Mu}$ tazilite concept of human responsibility is rooted in their understanding of the divine responsibility, which is deep-seated in the divine assistance. The assistance of God, however, aims to make duties easier to perform. 'Abd al-Jabbār defines it as "what gives the motivation for obedience without omitting the choice." ${ }^{101}$ It only motivates good acts and does not compel them; therefore, this assistance 
would not help non-believers because they would still keep the power of choice. Here 'Abd al-Jabbār, as a good Mu'tazilite, is eager to defend free will in all the different conditions of performing the divine law. God's lutf, therefore, is mainly motivatory and a challenge, by means of which the mukallaf is more likely to perform his duty. ${ }^{102}$

Nevertheless, 'Abd al-Jabbār explains that God for His part assists only those whom He knows to be likely to perform their duties with this assistance. Assistance granted to non-believers who would not perform their duties would be an act of useless 'abath. Therefore, revealed knowledge, for example, is considered lutf only to those who believe in it, for only through their belief will it assist them in performing the rational taklīf. Thus, God's assistance functions mainly for the sake of those who accept it as such. In this way God does not impose His assistance but grants it to those whom $\mathrm{He}$ knows are likely to believe. ${ }^{103}$ In this sense divine assistance is a grace which is offered to all but assists only those who believe. Divine assistance, however, is granted only in order to simplify or motivate the performing of the obligations imposed by rational or revealed taklīf. God, therefore, does not assist us to perform good acts which are not part of the divine law nor acts which lead to evil ends. ${ }^{104}$

Some opponents raise the question of whether lutf could also be granted to motivate non-believers to evil actions in order to punish them. ${ }^{105}$ 'Abd al-Jabbār denies such a possibility. His main argument here is that God neither does evil nor guides us to it because a just God, 'ádil, could not blame non-believers for what He had motivated them to do. ${ }^{106}$ Thus lutf does not function as such to all obligates, but rather only those who need this kind of assistance. Therefore, 'Abd al-Jabbār considers that there are some believers who do not need assistance in performing their takliff, while others would only believe on the basis of the divine assistance. He also considers that rational responsible people who do not receive revealed messages are still regarded as responsible, mukallafün, either because God perhaps knows of their disobedience or knows that they can believe without this assistance. ${ }^{107}$ This demonstrates the difference between lutf and tamkin, though both are forms of divine assistance: God's tamkin, Abrahamov points out, is the condition for performing an act and its opposite, whereas lutf assists the actual choice of the person to perform only good actions. ${ }^{108}$

To conclude, 'Abd al-Jabbār seems here to use the concept of lutf to disclose God's role in human life. God not only imposes laws but has also taken on Himself the duty of assisting people to obey them. God's activities, which succeed the decreeing of rational takliff, have the purpose of assisting its achievement. Thus, this divine assistance reveals a relationship between a just lawgiver and those subject to His laws whose utmost hope is to gain their deserved reward. However, it seems here that 'Abd al-Jabbār is mainly interested in disclosing the acts of God which reveal His justice rather than His essence. This seems to be one of the features of Islamic theology which can be clearly distinguished from mysticism. Mystics study God's acts mainly to 
discover who God is (His essence), as will be demonstrated in Chapter 4 on al-Ghazālī.

After outlining 'Abd al-Jabbār's view of the main features of divine assistance, we next examine the two ways of granting assistance to specific souls whose needs are known to God.

\section{Divine assistance through the warning of khawațir}

Assistance on the basis of God's knowledge of the specific needs of some persons is the main subject of Mughnz 13, but in Mughnī 11 'Abd al-Jabbār also mentions that God can influence the means of subsistence, rizq, of certain rationally responsible persons in order to prompt them to reflect on their life. He also can prevent them from subsisting by other means when He knows that their wealth would be enough to prevent them from obeying the revealed or rational commandments. ${ }^{109}$ In addition, God can also prevent the gift of having children when this would urge someone to reflect on his/her duties. ${ }^{110}$ Here we observe that God's assistance, lutf, is strongly connected with His knowledge of everyone's circumstances and the consequences of their actions, though this assistance is mainly directed towards the performing of our duties to one another. 'Abd al-Jabbār shows clearly that in these situations God deals with each case differently, giving His assistance on the basis of His eternal knowledge, which knows not only everyone's circumstances, but also the particular conditions of every different individual because it includes all knowledge, as explained here. ${ }^{111}$

However, al-Mughnī 12 and 13 provide two other situations where God grants assistance according to the needs of the individual. This assistance is even more effective and comes as a warning for those who fail to reflect on their rational and practical behaviour, which could lead them to punishment. These warnings are of two kinds: words which are created in the mind in order to call us to rational reflection (in al-Mughnz 12) or pain and suffering which God sends some mukallafün as trials to lead them to repent (in al-Mughñ 13). The present section will examine warnings in the form of words, khawattir, and the next will explore the pains and suffering sent from God.

Since reflection is regarded as a duty, 'Abd al-Jabbār discusses the motivation which encourages some to reflect. ${ }^{112} \mathrm{He}$ observes that some people are motivated through divine warnings, khawātir, which either come from God directly or through angels. God creates in some rationally responsible souls a fear of the danger of not reflecting on such questions as the existence of bodies, whether they are created, who created them and other similar questions. Some thinkers, however, are able to reflect on such questions without needing a warning, but others can only reflect when they fear the results of their ignorance. Thus, these fears motivate people to think and reflect and this leads them to a comprehension of God and of His rewards and punishments. ${ }^{113}$ 
"Abd al-Jabbār warns here of the devilish whisperings which could be confused with the divine khawattir. In order to distinguish between these two, we should realise that the khawattir which come from God direct our minds only to the importance of rational reflection, while the others invite us to do evil. ${ }^{114}$

\section{The nature of khawātir}

He examines here also the kind of act of which khawatitir is one; his aim is to identify the nature of this fear. He divides acts into two kinds: acts of the mind or rational acts, af'a $\bar{a}$ al-qulüb, and acts of the body (the limbs), af'a $\bar{a} l$ al-jawāriḩ. 'Abd al-Jabbār here argues that khawātir are words which belong to the acts of the body. Abū 'Alī al-Jubbā'̄̄, the Mu'tazilite master of Basra, in contrast, regards this fear as an act of the mind. Before presenting 'Abd al-Jabbār's argument, however, it is important to explain that words in Mu'tazilite theology are not classed as the acts of the mind but as acts of the body. Only ideas which denote either conviction or doubts are the activities of the mind. Words are the sensible form of ideas which can be heard by the ear and uttered by the mouth or seen as written.

'Abd al-Jabbār's argument is that if God were to create these words or ideas as convictions in our heart, then they would have to lead to immediate rational reflection. But our experience with these warnings shows, 'Abd al-Jabbār insists, that they only motivate and challenge reflection rather than compel it. Khawattir cannot also be doubts, he goes on, for if warnings were to come to the mind in the form of doubts, then they would not lead to reflection. ${ }^{115}$ Thus, khawattir must be classed as acts of the body (limbs) or the senses, af'a al-jawarib; however, they cannot be considered written or given through signs because they exist in the mind. As a result 'Abd al-Jabbār decides that khawativ must be words which are given in an apprehended language. They may be transmitted by an angel or from God, but, he stipulates, they must not be taken as personal communication from God to specific people - unless they are prophets - but rather in the same way as God in the Qur'ān talks to all people. ${ }^{116}$ Thus, khawātir for 'Abd al-Jabbār is a legitimate method used by God to direct the minds of responsible persons to the importance of reflection. However, we notice here that 'Abd al-Jabbār rejects the possibility of regarding these khawatitir as supernatural phenomena which might encourage a mystical form of personal relationship with God. He insists that God does not talk to individuals, but also tells us that these khawattir can take the form of a long argument convincing someone of the importance of reflection. ${ }^{117}$ However, the question arises, how could God conduct an argument to convince someone in a particular situation without relating to him personally? The same question made Abū 'Alī al-Jubbā'̄ reject the view of khawātir as words and hence arrive at the conclusion that it could only mean that God speaks to each person, although the Qur'ān reveals that God spoke only to Moses. ${ }^{118}$ In addition, $A b \bar{u}$ 'Alī argues, if these fears were verbal, then they could 
only be addressed to those who understand language and thus would exclude deaf persons from divine assistance. ${ }^{119}$ Thus, 'Abd al-Jabbār conversely argues that warnings are not words which are heard, such as the experiences of prophets, but enter the mind as the meanings of words. These meanings are understood by those in whom they occur and cause fear which raises different questions, prompting reflection. He also agrees with $A b \bar{u}$ 'Alī that the deaf and others who do not use language cannot be warned in this way. ${ }^{120}$ However, warnings which prompt people to reflection, 'Abd al-Jabbār believes, must not only be limited to khawātir, as Abū 'Alī claims; other methods of warning can also be effective here, according to the needs of the individual.

However, there is somehow inconsistency in 'Abd al-Jabbār's concept of khawattir. If khawätir are words which are revealed to the mind and often take the form of a long argument warning someone against being indifferent to reflection, then this can only demonstrate communication on a personal level. The rejection by 'Abd al-Jabbār of this conclusion seems to stem first from his criticism of the mystics and those who believe in Gnostic knowledge, Aṣhāb al-Ma'ārif, who hold that knowledge depends only on divine inspiration in the mind. ${ }^{121}$ However, it is also possible that his concern is related to the question of revelation, for if khawattir consist of divine talk on the personal level then they must be logically considered as revelation, waby, for they must be regarded as God's words given to a certain person. Therefore, he believes that they convey not words but the meaning of words and should not be taken as divine personal talk but rather as divine guidance.

The important of kbawattir here, however, is that they unveil a side of the Mu'tazilite theology which demonstrates their belief in a God who shows great concern for humanity. God's concern to assist human beings in their situation and provide suitable support presents the other side of the Mu'tazilite coin. God is usually pictured in their theology as a rational being whose activities are bound to forms of logic which mainly present His transcendence, but here we observe a God who has deep concern about each person and knowledge of the details of each life. He also takes the initiative in supporting the sincerity of anyone who shows interest in repentance. Next, however, we will look at the last aspect of divine assistance, when God sees the causing of pain and suffering as the only way of assisting some to repent.

\section{Warning through pain and suffering}

'Abd al-Jabbār discusses the problem of pain and suffering in connection with his discussion of divine assistance in al-Mughn $\bar{\imath} 13$. His intention here, however, is neither to investigate the problem of evil in general nor to deal with its sources but rather to examine one aspect of this problem: the purpose of that pain which is clearly identifiable as coming from God. My aim here is not to go through all his different arguments but to describe a further method of granting divine assistance to rationally responsible people. To do so, I will 
examine the definition of pain and suffering, the possibilities of considering them as good and the reasons for this kind of pain.

\section{Definition of pain}

'Abd al Jabbār in dealing with this problem starts by declaring that pain and suffering are perceived in a direct immediate way which does not need inquiry; only their causes must be known through acquired knowledge. ${ }^{122}$ His main argument here is that pain should be considered under the heading of taste and smell, which are necessarily perceived and therefore it is possible to distinguish between different kinds of pain just as we distinguish different tastes and smells. In this way pain should be considered as a temporal aspect which is caused by someone, either a human or God. ${ }^{123}$ He establishes the idea that pain is a generated action and not a primary one; for example, when someone hits another, the blow is a primary action and the pain which is caused by it is a generated one. In other words, pain comes always for a reason, either from a blow or torture or from sickness or something else. ${ }^{124}$

However pain and suffering are considered by many to be evil because they cause injury to the one who receives them. 'Abd al-Jabbār argues here against the opinion of the Thanawiyya group ${ }^{125}$ who consider that pain and suffering can only be considered evil because they are evil in themselves. ${ }^{126} \mathrm{He}$ argues that it is known necessarily that there are different kinds of pain which are conceded to be good, such as the pain which results from hard work which will be rewarded, or deserved pain and the like. ${ }^{127}$ First of all, he divides evil things into two different kinds: those which are evil in themselves and those which contain different aspects of evil, the absence of which could transform the thing from seeming evil to good. Suffering is of the second kind, 'Abd alJabbār explains, because it has aspects of evil which can be reversed. ${ }^{128}$ Therefore, it is important here to examine the concept of evil according to 'Abd al-Jabbār in order to understand how suffering and pain can lead to good acts. He defines wrongdoing, $z u l m,{ }^{129}$ as "any injury without benefit exceeding it or repulsion of harm greater than it and which is not deserved or thought to have any of these (ultimately good) aspects."130

\section{Sufferings which are caused by God}

Pain and suffering, in 'Abd al-Jabbār's theology, are considered evil only when (1) they confer no benefit, (2) they do not avoid greater harm, (3) they are not deserved and (4) there is no doubt about (1), (2) and (3). In other words, when they contain only aspects of evil. Thus, an injury is evil when it lacks all good aspects. ${ }^{131}$ But when these same four reasons which make pain and suffering evil are reversed, namely, (1) when they confer benefit, (2) when they avoid a greater injury or (3) when they are deserved, they should not be considered evil. This reversal simply removes the evil aspects of pain and suffering and transforms them from being evil acts into acts which are accepted 
as deserving no blame. Thus, when an agent causes pain to others in order to benefit them or in order to preserve them from greater harm or because it is deserved, then this pain cannot be considered evil, zulm. 'Abd al-Jabbār explains the three beneficent aspects of pain and suffering as follows:

1 Pain and suffering are good because they confer benefit When the good or evil aspects of the act change or disappear then the judgement of the act must change, though the injury and the pain remain. Thus, pain which aims to benefit others cannot be deemed evil nor its agent as unjust, zălim. However, the question here is how to tell whether the pain is inflicted with good or evil intentions? 'Abd al-Jabbār explains that the moral result of the pain and suffering must provide evidence which is known through necessary or acquired knowledge. In addition, this knowledge about the benefit of the pain should be known to the sufferer while he/she is still suffering in order for it to be appreciated. ${ }^{132}$ The benefit should be identified as the intention of the agent responsible for the suffering and it must also be greater than the injury, to allow the sufferer to bear the pain caused by it.

2 Pain is good when it prevents a greater injury 'Abd al-Jabbār considers that this reason is known to us through necessary knowledge, for example, running across thorns in order to escape from a lion, and numerous other examples. Also performing one's obligations is hard but yet good, because it avoids a greater punishment. ${ }^{133}$ However, the condition imposed here is that the harm which is faced has to be recognized by every person as greater then the pain endured and this should be known through necessary knowledge. ${ }^{134}$

3 Deserved injury 'Abd al-Jabbār considers that deserved pain is a kind of punishment and the appreciation of punishment is recognized by necessary knowledge, for it is admitted prima facie that evil actions deserve punishment and pain. ${ }^{135}$

The aim of the discussion above is mainly to influence judgements about pain and suffering when they are intended to cause benefit rather than injury. However, 'Abd al-Jabbār's intention here is mainly to provide arguments which will allow suffering and pain to be regarded as effects sent with the purpose of benefiting someone. His goal is to prepare the ground for conceding that some pain is sent from God, without characterizing God as unjust, zālim. Therefore, we now examine 'Abd al-Jabbār's grounds for justifying the pain and suffering which is sent from God.

\section{The reasons for sufferings caused by God}

First of all, 'Abd al-Jabbār clarifies that suffering is either caused by other humans or by God. ${ }^{136}$ He next explains the reasons why God causes pain and suffering. God does not cause suffering in order to let us avoid greater pain, 'Abd al-Jabbār explains, because He could protect us from this greater harm without our having to suffer. This, indeed, means that 'Abd al-Jabbār 
believes that God never decides to use suffering in order to confer benefit except when it is the only or the best way to do so. ${ }^{137}$ God, therefore, causes suffering either because of a benefit or because it is a deserved punishment. ${ }^{138}$ Here 'Abd al-Jabbār argues against the theory of a group called the Aṣhāb al-Tanāsukh (probably the Indian Barāhima) who asserted that pain is always deserved and considered as a punishment earned in a former life. ${ }^{139}$ 'Abd al-Jabbār argues here that the pain which God causes because it is deserved must only be inflicted at the last judgement, otherwise everyone who suffers pain must also be accused of sin. This is impossible, for 'Abd al-Jabbār, because the Qur'ān mentions many prophets who suffered pain in their sickness. ${ }^{140}$ In addition, all sick or suffering children would be regarded as sinners, which is impossible because they are not rationally responsible for any of their deeds. Therefore, the only possible way to distinguish between the sickness and suffering which God causes in order for the sufferer to benefit and the pain sent from God as punishment is to consider that deserved pain will be inflicted only at the last judgement. ${ }^{141}$

Thus, God causes pain only because it confers benefit. 'Abd al-Jabbār regards this benefit as an admonition, I'tibār, or a lesson, mibna, which leads to reflection on the reasons for this pain and its warning of danger. ${ }^{142}$ This pain, however, should be compensated for, 'Abd al-Jabbār explains, by some reward in the life to come, in order to remove all its evil aspects. 'Abd al-Jabbār explains that if someone destroys another person's robe, even for a good reason, he ought to replace the destroyed robe. ${ }^{143}$ Here he argues against Abū 'Alī al-Jubbā'î, who considers that God could cause pain only if the sufferer were rewarded with something better. 'Abd al-Jabbār here asks how can God reward someone by causing him to suffer. Compensation can only be regarded here according to him as removing all aspects of evil from God's act of causing pain and suffering to others, even though His intention was to benefit them. Thus, his aim here is not to think in terms of compensation, but rather to remove all aspects of evil which might be attributed to God's act. ${ }^{144}$ God sends pain and suffering only as an admonition and a lesson which warns the sufferer of his/her present situation and motivates him/her to reflect. 'Abd al-Jabbār also regards the suffering of children and the suffering which is caused through disasters as trials and warnings probably to others who are influenced by this disaster or to the parents of these children.

To conclude, pain and suffering for 'Abd al-Jabbār are perceivable temporal aspects which may have different reasons. The reasons for this suffering can be good or evil. When pain and suffering are caused by God then they must have good reasons, for God does not cause any evil nor does he lead us to it. God causes pain either as an admonition i'tibär or because it is deserved; however, the deserved punishments are mainly realized in the life after death.

However, the treatment of this problem here is not satisfactory because there are innumerable situations in which pain and suffering are not the result of anyone's action, and therefore they must be caused by God, but still cannot be accepted as a trial or lesson. Thus, it seems here that 'Abd al-Jabbār 
has simplified this problem and limited the meaning of pain to that of warning for the sake of reflection. Nevertheless, for our present purpose, pain and suffering express God's distinct ways of reaching different persons and urging them to reflect; for 'Abd al-Jabbār, this is the main issue. This concept expresses 'Abd al-Jabbār's deep belief in the ability of God to know the circumstances of all people and to use effective ways of helping them. In this way, God acts not only in history but also in each person's life.

\section{Conclusion}

'Abd al-Jabbār's theology concerns itself with the contemplation and interpretation of God's acts. He declares at the beginning of al-Mubit that God can only be known through His acts. This means that God's activities delineate His character and guide us to understand Him. In order to understand the purpose of His activities, 'Abd al-Jabbār analyses the process of the act and its different judgments. God's acts are directed to two purposes: to create in order to benefit others through decreeing the divine laws which guide them towards goodness and to assist us to earn the benefits we deserve, which is the goal of His obligations and of His creation. But although 'Abd al-Jabbār gives detailed information about the characteristics of God, he regards the purpose of knowing God as the knowledge of divine law.

Human beings, conversely, are created with certain qualities, mukallafün, which enable them to obey the divine obligations. However, 'Abd al-Jabbār shows clearly that the achievement of this task lies in the interactive relationship between God and humans. God grants warnings, khawatitir, and causes pain and suffering to some in order to urge them to turn away from other, unimportant things in life and to reflect on what brings eternal happiness. He also grants all necessary ideas and confirms His rational divine law through His revealed law. The task of humanity is to make use of the divine assistance and to start to reflect and acquire knowledge. In addition, people must free themselves from all previous traditional concepts which prevent them from reaching the truth.

God as the lawgiver and humans as the mukallafün who obey His law meet in 'Abd al-Jabbār's concept of lutf. Lutf demonstrates God's concern about human beings' ultimate goal. It reveals His nature and His sense of duty which guides everything towards good. This relationship, therefore, is mainly concerned about human voluntary obedience to God and God's assistance in achieving this. In the main it is an ethical relationship with the aim of motivating humans to act righteously on the basis of their knowledge of the nature of God. The aim of this relationship is mainly to achieve the deserved reward of entering the heavenly paradise. Although 'Abd al-Jabbār made great efforts in his study of lutf to depict God as the compassionate One, who by all means assists humans at every step to comprehend the divine law with its purposes, he failed to present a personal relationship between God and the individuals. By presenting a wealth of details and unveiling different aspects 
of God's assistance, lutf, he expands Mu'tazilism's concept of God to its absolute limits, but he fails to see the actual need of a mystical aspect in the knowledge of God because of who He is. It seems to me that, as a Mu'tazilite, 'Abd al-Jabbār here does everything possible to present man's deep relationship with God which needs the reciprocal support of both. Yet 'Abd al-Jabbār's interest remains at the level of God's reward and does not conceive of entering into His presence.

Lutf here presents the difference between theology (in its most advanced form) and Sufism. It presents a God who is interested in unveiling His will and hoping to see humans filling His paradise. This seems to be the ultimate hope of theology. Islamic Sufism, in contrast, directs its study towards knowing the mysterious face of God and declares its ultimate hope in the happiness of witnessing God's presence and uniting oneself with Him. The next two chapters, therefore, will examine mystical relationships from two different angles. Ibn Sīnā presents divine love, 'ish $q$, and the divine presence, tajalli, from a philosopher's standpoint. We shall notice, however that his mysticism is wholly tied to his philosophical analysis of the nature of God and the nature of the human. Al-Ghazālī (in Chapter 4) conversely takes more serious steps to unveiling the ultimate relationship between God and humans, but nevertheless, remains rational in his analysis of the experience of annihilation, fan $\vec{a}$, and unification, ittihăd. We will also notice that Ghazāli does not omit the ethical dimension from his Sufism but rather considers it only as the first step in the path of ascent. Thus the aim here of presenting 'Abd al-Jabbār's lutf as the first rank in these three relationships is to unveil, on the one hand, the limits of Islamic theology and to present, on the other hand, its important part in the journey of Sufism as Ghazāli understands it, and as will be elaborated in Chapter 4 .

Next, however, I shall present the ultimate relationship between God and humans according to Islamic philosophy through the eyes of Ibn Sīnā. 


\section{Relationship with God through knowledge and love, ' $i s h q$, in the philosophy of Ibn Sīnā}

After discussing 'Abd al-Jabbār's concept of lutf, which reveals the importance of knowledge in the relationship between God and the mukalaf, responsible believer, we turn here to examine another relationship which unveils other possibilities of relating to the Divine. Dealing with the concept of 'ish $q$ and divine love in Ibn Sīnā's philosophy opens up discussion of the tendency towards mysticism which cannot be overlooked when studying some of his works, such as his The Treatise on Love and the last part of his Remarks and Admonitions, known as the Sufi part. These works were probably the fruits of his earlier works, which Corbin calls the three visionary recitals of Ibn Sinnā: Hayy Ibn Yaqzān, Risāla al-Tayr and Salmān and Absāl, which present the human soul's journey to the divine world. These works were followed by the more complicated and mysterious book, which Ibn Sīnā calls $f \bar{\imath}$ al-Falsafa al-Mashriqiyya or fì al-Hikma al-Mashriqiyya (The Eastern Philosophy), in the prologue to Shifa . Ibn Trufayl was one of the earliest to point out the mystic dimension of Ibn Sīnā's philosophy when he quoted Ibn Sīnā's remark that al-Shifä' does not represent his real concepts; these are to be sought instead in his work The Eastern Philosophy. This is the name of a lost work of his, which, according to Gutas, was probably written between AD 1027 and 1029. ${ }^{1}$ This statement made many scholars think that Ibn Sīnā was presenting in The Eastern Philosophy a kind of philosophy which differs altogether from his public one. Ibn al-Rushd, for his part, considers that it presents the doctrines of the Eastern philosophers, probably of Khurāsān. However, Gutas confirms, from his research on the subject, that a work with the title The Eastern Philosophy or The Easterners was lost during Ibn S̄̄nā's lifetime and was read only by very few of his disciples. Therefore all the notes which are contributed by later philosophers refer only to their interpretations of Ibn Sinnā's own remarks about this work. Ibn Sīnā's strongest comment about this work is found in the prologue to al-Shifa $\bar{a}$ in which he says:

I also wrote a book other than these two [Shifä' and the Appendices] in which I present philosophy as it is in itself and which is dictated by a basic attitude which neither takes into account [in this book] the views of colleagues in the discipline, nor takes precautions here against 
creating schisms among them, as is done elsewhere. This is my book on Eastern Philosophy [wa huwa kitabì fī al-Falsafa al-Mashriqiya]. ${ }^{2}$ But as for the present book, it is more elaborate and more accommodating to my peripatetic colleagues. Whoever wants the truth [stated] without indirection, he should seek the former book; whoever wants the truth [stated] in a way which is somewhat conciliatory to colleagues, elaborates a great deal and alludes to things which, had they been perceived, there would have been no need for the other book, should read the present book. ${ }^{3}$

This remark about The Eastern Philosophy or, better, On Eastern Philosophy, as Ibn Sinnā names it here, makes it clear that this book does not present his ideas in the manner and terminology of the pure peripatetic philosophers but reveals his own opinions and doctrines, whatever they may be. The importance of this work is that it sheds light on the development of Ibn Sīnā's mystical thought, which probably started with his three visionary recitals mentioned on page 74 . It could form a link between those earlier symbolic works which were probably written at the end of his period as vizier in Hamadhān and the beginning of his time in Iṣfāhān, and his later works, The Treatise on Love (probably written just before Remarks) and Remarks and Admonitions (AD 1034).

The only surviving fragment of this work is its introduction and some passages on logic and physics. Ibn Sīnā in this introduction makes four points: first of all that Aristotle acknowledged the truth in most sciences, classified them and discovered their fundamental principles. He considered that "This is the utmost that can be accomplished by a person who was the first to try his hand at separating what lay confused and restoring what has been impaired." 4 The second point is "but his successors were unable to free themselves from the imperfections of what they inherited from him"; 5 in other words they followed him without adding anything of their own. The third point is concerned with Ibn Sinnā's colleagues whom he disagrees with

now since those who are occupied with philosophy are forcefully asserting their descent from the Peripatetics among the Greeks, we are loath to create schisms and disagree with the majority. We simply joined their ranks and Adhered in a Partisan spirit to the Peripatetics, since they were the sect among them the most worthy of such an Adherence. ${ }^{6}$

He says of this group of Arab philosophers:

as a matter of fact we were afflicted with a company of them as devoid of understanding "as [if] they were propped-up blocks of wood" [Qur'ān. 63:4] who considered profound theoretical analysis a heresy and disagreement of what is widely accepted as a diversion from the right path as if they were the Hanbalites among the authors of the Peripatetic tradition. ${ }^{7}$ 
He shows here how he disagrees with most of his colleagues. Finally, he explains that in this book he discloses his opinion, which is in opposition to most of his colleagues, in order to unveil "the fundamental elements of true philosophy."

Thus, it seems here that Ibn Sinnā, on the one hand, is disclosing the points where he criticizes the Aristotelian tradition and, on the other, is explaining the errors of the Arab philosophers on some issues. However, his intention is stated clearly - to disclose his own opinion and unveil "the fundamental elements of true philosophy."

Some recent scholars believe that this work would have revealed the mystical tendency of Ibn Sīnā. ${ }^{9}$ A. F. Mehren connects this idea with Ibn Sīnā's visionary recitals and considered that the truth for Ibn Sinnā is the mystical dimension of his later philosophy. ${ }^{10}$ Corbin also considers that the idea of the East here is not so much a geographical notion as a mystical one. He relates the East to the journey of the soul to the Orient, which is mentioned in the visionary recital of Hayy Ibn Yaqzāan. The Orient in Hayy, according to Corbin, is a symbol of the divine world and therefore he interprets the Orient or the East as expressing the true philosophy by which the soul is led to return to the divine world. ${ }^{11}$

The problem of how to interpret Ibn Sīnā's usage of the term "East" led to protracted research by many scholars. Is the East a symbolic idea referring to light and the divine world as it is in his references to the East in both his treatises Hayy Ibn Yaqzān and al-Tayr? Or does it refer to a geographical direction which either points to the philosophers of Khurāsān, as Gutas upholds, or the medical methodology of the school of Jundishāpūr, as A. M. Goichon maintains? ${ }^{12}$ The difficulty is that Ibn Sīna himself uses the term "Eastern," sharq, mashriqiyya to indicate both the meanings mentioned above, as Gutas shows in the testimonia. ${ }^{13}$ He speaks of his book $f_{\bar{z}}$ al-Falsafa al-Mashriqiyya or fí al-Hikma al-Mashiqiyya, which reveals views of his which should not be made public, as Sufis usually maintain. But he refers also to his Eastern topics of al-Masa'il al-Mashriqiyya, where he discusses some queries or issues which could have been raised by some colleagues. ${ }^{14}$ In addition, he mentions a work with the probable title of The Eastern Demonstrative Proofs, al-Burbān al-Mashriqu , and finally, in his lost work al-Inșäf he speaks about two groups of philosophers, the Easterners and the Westerners. ${ }^{15}$ Thus, we see that Ibn Sinna uses the word "East" to refer to the thought of the philosophers of the east and the problematic issues which they raise, but also he clearly talks about his book The Eastern Philosophy as something which presents "philosophy as it is in itself." The question here is whether "philosophy as it in itself" has a mystical meaning for Ibn Sīnā or just differs from the popular Aristotelian one?

The opinions of recent scholars on this point differ greatly: Gutas, for example, believes that Remarks and Admonitions reflects the final truth for Ibn Sīnā, as he himself declares: "Dear friend: I have churned for you in these pointers the cream of truth (al-haqq) and have fed you choice morsels of philosophy (bikma) in pithy sayings." ${ }^{16}$ Gardet considers that Ibn Sīnā means 
here by "true philosophy" the philosophies of Pythagoras, Plato and Plotinus. Although Pines considers that "Easterners" here refers to the philosophers of Khurāsān, Nasr points out that Ibn Sīnā in his works emphasizes the importance of the soul and its substantial role as an immortal element separable from the body and leading to the acknowledgement of the divine world which is also a philosophical element in al-Balkhī and al-'Āmīrī. In contrast, Corbin and some Muslim scholars consider that The Eastern Philosophy is neither Aristotelian nor Neoplatonic but mainly influenced by ancient Persian philosophy, as it in turn influenced Suhrawardī's illumination theory. Corbin considers that the term "East" here refers to the realm of light, which means in the first place wisdom of theosophy aiming to deliver the human soul from the material world. ${ }^{17}$

Since Ibn Sīnā wrote The Eastern Philosophy after Hayy Ibn Yaqzānn and the other esoteric treatises, it is most likely that this work had a similar character to these esoteric works. This probably formed a link with his Sufi and mystical feelings which were expressed in his works A Treatise on Love and the last part of Remarks and Admonitions. With the term "mystical" I refer here to the kind of philosophy which concentrates on the journey of the human soul from the material to the eternal divine world. This journey is based on the soul's salvation through both knowledge and the vision of the light. Knowledge has the role here of directing the soul's interest to the divine world but its final arrival depends only on its ascent through spiritual exercises and experience of different states in which it catches a glimpse of divine light. This is exactly how Ibn Sīnā explains the mystical ascent of the saint in the Sufi part of Remarks and Admonitions.

The last point which still needs exploration here is whether the kind of mysticism which Ibn Sīnā introduced here can be called Islamic. To this question Morewedge's discussion in both his articles on "The Logic of Emanation and Sufism in the Philosophy of Ibn Sīnā," Parts I and II presents the views of some different scholars on the mystical dimension of Ibn Sinnā's philosophy. They can be divided into the following groups:

1 Scholars who consider that Ibn Sīnā's concepts are mainly philosophical and should mainly be understood in the light of Shif $\bar{a}$, his greatest work, as A. M. Goichon and E. Gilson maintain. ${ }^{18}$

2 Scholars who consider him to have a mystical dimension though he never had a Sufi experience, and therefore this dimension has to be interpreted within his whole system, such as L. Gardet and G. C. Anawati.

3 Scholars who consider that his Sufism should not be considered as Islamic but rather a kind of natural mysticism. This kind of natural Sufism relates itself to an ultimate Being who neither knows the Sufi nor experiences his love. ${ }^{19}$ To this group belong scholars such as J. J. Houben ${ }^{20}$ and R. C. Zaehner.

4 The fourth group considers that Ibn Sīnā in some of his works describes a mysticism which is influenced by Neoplatonic and Zoroastrian 
mysticism (Zoroastrianism is a pre-Islamic belief which was mainly popular in Iran). ${ }^{21}$ The main proponent of this view is H. Corbin who wrote a long work on the three visionary recitals of Ibn Sinnā mentioned on page 74 . He considers that these three recitals consist of one cycle which describes the journey of the soul to the Orient, which he interprets as the divine world, and the human soul's final return to its origin. ${ }^{22}$ To this group belong also other scholars such as S. Pines, S. Afnan and Morewedge himself. ${ }^{23}$

It does seem here that these scholars mentioned above, in some way or another, agree that some of Ibn Sinnā’s works have a mystical tendency but disagree about how to understand and relate these works to his other philosophical works. This problem, however, requires a separate study which cannot be undertaken here. Instead this chapter will concentrate on tracing Ibn Sīnā’s concept of divine love, 'ishq, and attempt to relate it to his concept of God and human soul and knowledge. Our main emphasis here will be on the two works of Ibn Sīnā, The Treatise on Love and the last part of his Remarks and Admonitions known as the Sufi part. We will attempt here to connect his concept of 'ishq with his notion of God's tajalli, the divine light which attracts the divine intellects and the whole world towards Him. In order to perceive the importance of those concepts in Ibn Sinnăs mystical thought, however, we need to examine his perception of the nature of God and the nature of human beings with their different possibilities of reaching the knowledge of God.

This chapter will be divided into three sections: the first section examines the characteristics of God according to Ibn Sīnā, under three sub-sections. The first of these examines the attributes which Ibn Sīnā ascribed to God. Our aim here is to show that these attributes disclose both the essence and the manner of God's existence. The second sets out the relation between God and the world through Ibn Sīnās theory of emanation. The third sub-section explores God's relationship to the individual.

The second section investigates the human soul which Ibn Sinnā studies in three different contexts and here will be examined in three sub-sections. The first examines the faculties of the human soul, the second discusses Ibn Sinnās concept of knowledge and the third explores his concept of religious knowledge.

The third section of this chapter discloses the ultimate relationship to which some human souls can ascend to obtain a direct conjunction with the divine presence. In order to study how this goal is reached, we will examine three concepts: the concept of the substantiality of the human soul, the concept of love according to the different works of Ibn Sinnā and the manifestation of God which Ibn Sīnā calls tajallī. This tajallı̄ is always present and is the only possibility of reaching a direct relationship between human beings and God. Thus, the last sub-section of this section considers the ascent of the human 
soul towards a conjunction with the divine manifestation, according to Ibn Sīnā's last great work Remarks and Admonitions. Now we turn to explore the main features that Ibn Sīnā ascribes to God.

\section{The main characteristics of God}

Studying the kinds of relationship between God and humanity often calls for a description of the kind of God which the particular theologian or philosopher has in mind and predictably this image of God influences strongly the type of relationship that may occur between God and humanity. To reach an understanding of the concept of God which influenced Ibn Sīnā's philosophical thinking, we attempt here to explore Ibn Sinnā's concept of the knowability of God. We do not mean here the question of the existence of God but rather the image or the character which Ibn Sīnā attributed to Him. ${ }^{24}$ To do so, we will examine the question of the knowability of God through the attributes which Ibn Sīnā attributed to Him but we are mainly interested here in the attributes which invite and lead to a relationship with God. We will also examine in the next sub-section the relationship between God and the world and finally under the last sub-section discuss the question of God's knowledge of individuals. These three concepts disclose the main features of God according to Ibn Sīnā.

Unlike 'Abd al-Jabbār, Ibn Sīnā did not believe that the act of creation is the main event which proves God's existence; rather, for him, the existence of the world demonstrates that it must have a first cause. This first cause stands as the first impulse which brought about existence. Ibn Sīnā provides many names for this cause: the First, since He is the beginning; the One, from the consideration of His nature; and the Necessary Existence, for He is the only one whose existence comes from within Himself.

The search for the characteristics of God is a dominant feature in the theological part of both Ibn Sīnā's works al-Shifä' and al-Najāt, and also in The Treatise on Love and the last part of Remarks and Admonitions though in different images. No doubt Ibn Sinnā, in seeking the attributes of God, was strongly influenced by Greek philosophy and its interpretation through Jewish and Christian thought; nevertheless, one can still trace some vestiges of Islamic influence. As a devout Muslim who grew up in the Ismā'îlī tradition, Ibn Sīnā perceives God as the absolute transcendent, but also the source of existence, love and knowledge; features which are found in Neoplatonism and in many Qur'ānic and Hadīth passages such as the Hadīth which he mentioned in his The Treatise on Love: "God has said: If my servant did this and this he will love me and I will love him." 25 In some parts of his works we encounter God as the only Necessary Existent and in other parts we perceive Him as the source of knowledge, beauty, goodness and love. Thus, Ibn Sīnā's image of God does indeed open the possibility of a mystical tendency such as can be seen in his later works. To reach an understanding of the concept of 
God which influenced Ibn Sīnā’s philosophical and mystical thinking, I want next to discuss the divine essential attributes in Greek thought and then to examine Ibn Sinnā's attributes of God in the light of Greek and Islamic thought. The question of creation and God's knowledge will also be explored in this chapter in order to have a fuller comprehension of Ibn Sīnā's concept of the divine One.

\section{The essential attributes of God}

To open our search for the essential attributes of God in Ibn Sinnās philosophy, I shall first present a brief discussion on the divine attributes in Greek thought. Wolfson explains that in the Greek tradition Plato had started to discuss the question of whether we are able to name the attributes of God; this occurs within his discussion of the possibility of attributing the divine ideas. Plato believed in the existence of a divine world which contains universal ideas and concepts, such as justice, goodness or beauty, governing our world. For him, God is most probably one of these ideas or a concept which stands above all of them. The key question for him was whether it is possible to describe these divine ideas or only to prove their existence. The problem for Plato was not mainly in the nature of these ideas, which were presented as incorporeal, abstract and imperceptible to the senses, but the fact that he believed in the real existence of these ideas as a kind of divine Intellect (or angels). Thus, any predicate - which is also an idea - which attempts to describe another idea would in fact combine the two ideas together and thus violate their simplicity. But Plato discerned that one idea could possibly participate in others so long as they do not contradict one another, for example, the idea of good participating in the idea of existence and oneness. ${ }^{26}$ In this case one can describe a divine idea through its participation in other divine ideas and without destroying their simplicity provided that conflicting ideas are not combined.

In contrast, Aristotle believed that ideas exist only in the mind and not outside it. Therefore, for him predicating rational conceptions of God would not impair His unity, for rational concepts have no existence in reality. They are only a logical attempt to describe God with the awareness that predicates which are used to describe both humans and God are used about God in their perfect form. Moreover, Aristotle accepted the possibility of defining God in terms of a genus and species, which define the essence of the thing, according to his theory of definition. He explains that since genus and species do not exist in reality but are only rational descriptions, they do not violate the unity of God. In this way Aristotle admits that one can describe the essence of God in terms of genus and differentia by identifying His genus and differentiating Him from others, and this discloses His uniqueness. ${ }^{27}$

The concept of the unknowability of God's essence started, according to Wolfson, only with Philo Judaeus (d. AD 40), a devout Jew who tried to assimilate Greek philosophy and Jewish thought. For him, God as presented 
in the scriptures is unlike any thing: He is unnamed and incomparable. Philo modified the Platonic God by making Him the creator of all other ideas, which he considered like angels. God, for Philo, has created the world through what he identifies as logos, probably to be understood as the first Intellect. ${ }^{28}$ But his Jewish image of God as unknowable remained the governing feature of his philosophy. He explained that one could only describe God in negative terms, for He transcends all description. These negative terms make God abstract and declare only His existence. ${ }^{29}$

This concept of God carried weight for many centuries, notably among the church fathers. ${ }^{30}$ Plotinus also believes that it is impossible to know and perceive the essence of God; one can only know the existence of God through the things which proceed from Him. But Plotinus asserts that God cannot be in the same genus as these things, and all attributes of God, which are the only way to describe His existence, should be considered as His exclusive properties, which no one shares with Him. Thus, the only way to speak of God is through the proofs of His existence or through His relationship to the world or through negative attributes, which show the unlikeness of God to all things. ${ }^{31}$

The Hellenistic concept of God has some affinities with the overall image of God in the Qur'ān, mainly in His unity and transcendence but Muslim theologians did not hesitate to define the essence of God with what they called the attributes of the essence, sifāt al-dhāt, believing that the attributes which God attributed to His essence in the Qur'ān do disclose Him. However, the problem of relating these attributes to God, whether they are part of Him or are eternal concepts predicating Him, remained an area of debate between the Mu'tazilites and the Ash'arites, as outlined in Chapter 2.

Ibn Sīnā, like Philo and Plotinus, considers that the unity of God means that His essence is simple and indivisible and that any attempt to describe it would violate this unity. The essence of God is indivisible both into parts, such as soul and body or matter and form, and into logical divisions such as genus and species or existence and essence. This difficulty of the unity and simplicity of God made Him indefinable for Ibn Sīnā because definition, according to him, consists of relating a thing to its genus where it shares qualities with others and specifying or differentiating it from these others through its specific qualities. ${ }^{32}$

Ibn Sīnā, nevertheless, applies many attributes to God but he considered them all as properties. Properties in Ibn Sīnā's theory of definitions are able only to describe the thing but cannot define its essence. In this way he could attribute qualities to God without violating His absolute unity and simplicity and was able to preserve the uniqueness and unlikeness of God because these properties were considered to belong to Him alone and should be used predicatively when they are used in connection with human beings. ${ }^{33}$ Ibn Sīnā took this idea from al-Fārābī, who considered that attributes which are used to describe both God and humans attribute qualities primarily and in perfect form to God and then derive the human attributes from them. This means 
that it is not God who shares an attribute with us but we who are credited with an attribute of His. ${ }^{34}$

At this stage Ibn Sīnā, following Plotinus, uses some properties mainly to describe the existence of God rather than His essence, as we see in the following passage from Najāt:

the first attribute of God is that He exists and all other attributes manifest this existence either by addition or with negation and none of them imply multiplicity or anything contradictory in His essence. The ones [attributes] which express negation are such as when someone said about the First (God forbid) that He is a substance; he did not mean other than that this Existence was not in a subject. And if someone said that $\mathrm{He}$ is one, he did not mean other than abstracting from this Existence numeral or logical division or association. And if it is said that ( $\mathrm{He}$ is) Intellect and knowable and knower, it does not truly mean other than abstracting from this Existence the possibility of its being mixed with matter or its relations, in considering a certain addition. And if it is said He is first, it does not mean other than adding to this Existence the universe and if it is said about Him that $\mathrm{He}$ is able, this does not mean other than adding the existence of others to the Necessary Existence, as we said before... if you perceive the attributes of the True First in this respect than there will not be in any respect either division or multiplicity in His essence. ${ }^{35}$

Some observations can be made here. The attributes mentioned above only describe the kind of existence which God has. This description is in three forms: first, through negation, which means abstracting from Him what cannot be applied to His existence, like all relations and consequences of matter. Second, describing through adding what can be applied to this existence or what happens through His existence, such as the existence of others. ${ }^{36}$ Third, describing through adding and abstracting, as when someone says that God is Intellect, ' $a q l$, which means His existence is free from matter and therefore must be an intellect. (There are two forms of existence traceable in Ibn Sinā's works: the existence of material things and the existence of immaterial intellects which govern the material world.) But we have to ask here whether Ibn Sinnā's objection to describing the essence of God in such passages relates to the nature of the unity which he attributes to God, as he confesses at the end of the above passage, or whether it is a philosophical difficulty, which means that he actually believes in the unknowability of God.

From the discussion above we can assume that the difficulty is in fact how logically to avoid violating God's unity through conferring attributes upon Him. However, Ibn Sīnā, I believe, does define God or at least draws a clear image of Him. We can see this first in Ibn Sīnā's theory of "essence and existence" which states that God is the only being whose essence is identical with His existence, ${ }^{37}$ because His existence comes from within His essence, whereas the existence of all other beings is added to their essence. This means 
that the existence of all beings is dependent on another while the existence of God comes from within Himself. Therefore, His essence is identical to His existence and His existence is His essence. This makes the conclusion inevitable that whatever describes the existence of God describes His essence as well.

Ibn Sinnā describes God as pure goodness and pure intellect and in the Treatise on Love he attributes to God pure love. We can see that some of the qualities which he attributes to God, such as knowledge, love and goodness, overflow from Him to all other things. In Risăla fì al-'Ishq (The Treatise on Love) Ibn Sīnā explains that love is implanted in all things; in matter in its yearning toward form, and in movement in its yearning toward its mover and in voluntary love which is yearning toward perfect love in God. ${ }^{38} \mathrm{He}$ tells us also that this love is a part or even the cause ${ }^{39}$ of the existence of all things and it emanates from God. This love, as Ibn Sīnā explains, emanates from God first to the Intellects and then indirectly to all other beings. ${ }^{40} \mathrm{He}$ also makes a very interesting statement at the end of the first chapter of this treatise, as follows:

therefore His love towards Himself is the most perfect and fullest love because there is no differentiation between the divine attributes in the essence, hence love is the manifestation of Essence and Existence (al-'ishq buwa sarīb al-dhāt wa al-wujūd). ${ }^{41}$

By this he admits that love is in or is the essence of God. The same can be said about goodness, which he explains in the section on God's providence for the world in Najāt and Shifä' and al-Risāla al-'Arshiyya, saying that it flows from God to all existence ${ }^{42}$ and causes the world to be well-ordered, nizām al-khayr.

Knowledge, to Ibn Sīnā, also has its source in God, as he explains in his comment on Theologia Aristotelis (Kitāb al-Inșāf): through God's manifestation to Himself, tajallī, all intellects receive an overflowing of knowledge which makes them know themselves and know God. ${ }^{43}$ Thus love, knowledge and goodness flow from God to all humanity and here the question arises how it is possible that these attributes emanate from God unless they are parts or the content of His essence?

Thus, although Ibn Sīnā avoided defining the essence of God, in order that His unity might not be violated, he showed in different writings that in fact he has a clear image of God and that one can define Him philosophically, though keeping in mind that technically His essence is indivisible and simple. This image is not only influenced by Greek tradition but also very much by the Islamic one, which, although it accepts that God is one and transcendent, also holds that $\mathrm{He}$ is close and definable, as the Qur'ān in many verses defines Him. Therefore God, in the view of Ibn Sīnā, is pure Intellect, pure goodness and pure love and perfection and is, at the same time, absolutely One; with all His qualities He transcends all other creatures in the way that all His 
attributes are attributed to Him first and in their perfect form. His transcendence is also manifested in that $\mathrm{He}$ is the only Necessary Existence and $\mathrm{He}$ is the only being whose essence is identical to His existence. Consequently, God for Ibn Sinna is both on the one hand the transcendent and absolute One and on the other hand is immanent, through the qualities of His essence/existence which flow from Him to the whole world. This opens the possibility of a relationship between Him and the world and between Him and humanity. In the next section, we will examine the way in which the character of God influences the generation of the world and the way in which this generation influences the forms of communication between God and humans.

\section{God's relation to the world}

After the main features of God, we turn now to examine how these qualities influence the process of bringing the world into existence. For Ibn Sīnā, God is basically the transcendent and absolute One and, consequently, absolutely immaterial and His existence has no potentiality. These exact qualities show the difficulty of generating or creating the world, for when the world as it exists contains such opposed qualities as materiality, potentiality and plurality, then how can a God with fundamentally opposite qualities create or generate a world. ${ }^{44}$ This problem appeared first in Greek philosophy, mainly between the Aristotelian and Neoplatonic traditions. Aristotle believed that the First who gives the first movement is Himself the absolute prime immovable Mover and, consequently, immaterial, which means purely Intellect. ${ }^{45}$ As a pure Intellect, Badawi points out in his book Arist $\bar{u}$, God's main activity is thinking but His intellection and knowledge are absolutely concentrated on Himself because He is self-sufficient, neither needing others nor needing any act of production. The reason is that the act of production implies a need and a purpose between the producer and his production because if a producer produces something of which he neither needs nor benefits then his production is useless to him. Therefore, the problem here for Aristotle was "How is it possible to consider that God in any way produced the world." This led him to believe that the world and God exist eternally beside each other. ${ }^{46}$

Plotinus tried to solve this problem by explaining that the production of the world does not happen through an act and an effort of will, but is an emanation from God just as water pours out from a very full container. The first being, which emanated from Him, was one Intellect because, for Plotinus, only one thing can be produced from God as the absolute One. He called this the Universal Intellect, from which emanates the Universal Soul, which in turn produces the universe. ${ }^{47}$ In this solution, the oneness of God is not destroyed in producing the many, for the production in this case happens through mediators and God does not need to act or to have a purpose for this production. But although Plotinus solves the two problems of how the world is produced without an act of will and how the one produces the many, 
Netton explains, he creates a new problem: how the transcendent emanates the world out of Himself and yet remains transcendent, since a world created in this way would necessarily have great similarities with its source. Even though Plotinus believes that "the First remains the same even if other things come into being from it ${ }^{48}$, Netton rightly questions "how the transcendence of the One can remain intact and uninfringed." ${ }^{49}$ Therefore, emanation can solve only a part of the problem of preserving the inviolability of God's nature despite His bringing the world into existence. Hence, we examine how Ibn Sīnā deals with this problem.

Ibn Sinnā adopted mainly al-Fārābī's system of emanation but nevertheless introduced some new concepts. We should briefly here present al-Fārābī’s emanation scheme: he mainly presents a series of Intellects, which stand between God and all other beings. He considers that from God the First emanates only the second Intellect (since Fārābī considers God to be the First Intellect) as a result of the contemplation of God. ${ }^{50} \mathrm{~A}$ third Intellect emanates from the second Intellect as a result of its contemplating the First and also produces the first heaven as a result of its contemplation of itself. The fourth Intellect emanates from the third Intellect and produces in the same way the fifth Intellect and the fixed stars. This process continues, producing Jupiter, Mars, the Sun, Venus, Mercury and the Moon. The Intellect which produces the Moon is the eleventh Intellect, which is also called the Active Intellect. ${ }^{51}$ These Intellects are differentiated in ranks and in the portion of existence allotted to each. ${ }^{52}$

Ibn Sinnā follows this system in the main, but the first point on which he fundamentally differs from al-Fārābī is that he does not consider God to be the First Intellect; for Ibn Sīnā, God is above the scheme of emanation. ${ }^{53}$ Although He produces the first Intellect as a result of His contemplation of Himself, this Intellect is absolutely different in its nature from Him. God for Ibn Sīnā is the only Necessary Existent, whereas all other beings, including all the divine Intellects, are conceivable only in the sense that their existence is added to their essence and they are fully dependent on God. ${ }^{54}$ Therefore, the nature of all the Intellects is different from the nature of God, mainly in containing the plurality of having possible existence in themselves and having been called into existence by the One. Nevertheless, Ibn Sīnā continues to refer to God as the First, probably to assert the emergence of a world dependent on Him. But he counts the Intellects, starting with the first emanated Intellect and ends with the tenth as the Active Intellect.

In this way God transcends the system and does not simply stand as the highest in rank of the eleven Intellects, as al-Fārābī maintained. Thus, there is a basic difference between God and the first Intellect, according to Ibn Sīnā. ${ }^{55}$ The latter's existence includes potentiality and possibility in itself: "the possibility of its existence is an element which It has in itself and is not caused by the First, but from Him It has its necessary existence." 56

However, Ibn Sinnā was also interested in the way in which God and the Intellects generate beings. He asserts that the generation of the first Intellect 
from God was neither an act of will nor an act of natural mechanism, bi-al-tab, he says:

[I]t is not that the being of the others from Him in the way of natural mechanism in which the existence of the all from Him would be without His knowledge and acceptance - how can this be? - and He is a pure Intellect who knows Himself; consequently $\mathrm{He}$ must know that the existence of the all must be from Him... He knows that the existence of all is from Him and that He is their beginning and that there is nothing in Him which objects to or dislikes the emanating of all from Him. His essence knows His perfection and transcendence, and that the emanation of goodness is from Him and that this is a necessity of His beloved essence. $^{57}$

Thus, things do emanate from Him according to His will, but this will differs from ours; it does not have a certain purpose which God wants to achieve but His will acts according to His knowledge. When God contemplates Himself, He causes the existence of the first Intellect because His essence has the quality of being a source of emanation, though contemplation is not a necessary process but it must happen according to a certain will. In this way Ibn Sīnā is probably approaching the God of his religion in showing that the way in which things emanate from God demonstrates His pre-existent knowledge of the world and its generation according to His plan.

After the generation of the first Intellect according to God's knowledge and acceptance, Ibn Sinnā explains, the first Intellect and each of the other Intellects has a three-fold contemplation: (1) on God as the reason of its existence, (2) on itself as a necessary existent and (3) on itself as a possible existent. It therefore produces three things: another Intellect, a material form, al-șüra al-mādīa, or a soul, and matter. ${ }^{58} \mathrm{Ibn}$ Sīnā here probably seeks to show how the Intellects produce matter and form. In addition, he wants to show here that the Intellects are absolutely aware of what is happening and again their production is not mechanical; they are also aware of the position and transcendence of God and of their own rank and position in the world system. In his commentary on Theologia Aristotelis, Ibn Sinnā shows that through the manifestation of God, tajalli, the Intellects not only know God but also become aware of themselves, as will be shown later in this chapter. ${ }^{59}$

This point is important for our subject because Ibn Sīnā here draws a relationship between knowing oneself and knowing God and recognizing the position one has in the world. This asserts his awareness of the importance of individuality and particularity in the system; neither God nor the Intellects are absorbed in the system because each of the Intellects knows itself and the role which it has and knows that the achievement of its role lies in the fact that God is above the system and guarantees its function. This causes Ibn Sinnā to move away from the strictly Neoplatonic notion of necessity which indicates that the emanation process includes a necessary system of existence which 
functions without the interference of a divine will. Ibn Sīnā here makes clear that each agent in his emanation plan is aware of its role and of the importance of God in this plan. This, on the one hand, inclines towards the religious view that the world functions in accordance with a divine providence, but at the same time this divine system differs from the Qur'ānic divine guidance which can at any time be reversed, as God pleases.

The Active Intellect in Ibn Sīnā's emanation theory is the closest Intellect to us, which gives it a very important, even central, function in human life. ${ }^{60}$ First of all, through the Active Intellect, with the help of the celestial souls, the substratum of matter is generated containing the four elements, (earth, water, fire and air) which are the basis of the creation of the sublunary world. The Active Intellect also generates human souls and the forms of all things. ${ }^{61}$

But although Ibn Sīnā gives the Active Intellect the role of the "creator," as Netton points out, he considers it to be the angel Jibrīl, whose function in Islam is to bring a full understanding of God to humans. ${ }^{62}$ He dedicated to Jibrīl his mystical treatise Hayy Ibn Yaqzān and considers this angel to be the son of God. To revert to the role which the Active Intellect plays in rational and mystical knowledge on earth, Ibn Sīnā recognizes the great importance of the Active Intellect in illuminating the human intellect, but even so he considers that the ultimate aim of humanity is to have direct conjunction with God, as he shows in the Sufi chapter of his work Remarks and Admonitions.

Although it seems here that God and the Intellects are partners in the generation of matter and form, which is wholly dependent on the Intellects, Rahman points out that, unlike Aristotle, Ibn Sīnā, in his theory of "essence and existence" finds that matter and form cannot, through their relation to each other, bring themselves into existence, but need a third element. ${ }^{63}$ Aristotle states that every material existent thing must have matter and form; matter is its potential existence and form is the factor which actualizes the matter and brings it into an existence composed of combined matter and form (a material thing). Thus, every material existence has a duality in its essence. Ibn Sinnā accepts this duality but raises the problem of how the composite of matter and form can come into existence when all contingent possible beings depend for their existence on a borrowed existence from another. For if the form has the ability to bring matter into existence, then it is in itself a kind of necessary existence (or a God). Therefore, the duality in all things is not of matter and form but of essence and existence, because the composite essence: "matter and form" needs a third element in order to come into being. As Burrell explains, this is "because all essences are essence of possible beings, and the proper character (of such being) is that they necessarily require some other thing to make them be in act." ${ }^{64}$ Ibn Sīnā, Burrell maintains, changed the Aristotelian formula of matter and form into essence and existence in order to assert that matter and form needed to be joined by a third factor to come into existence. ${ }^{65}$ Rahman, therefore, considers that if existence can only be conferred by the Necessary Existence, the only One whose existence is 
within His essence, consequently, is God; for Ibn Sīnā, God is the only one who gives existence to all things and therefore $\mathrm{He}$ is the only One who can bring all beings directly into existence. ${ }^{66}$

In this sense Ibn Sīnā in his emanation theory offers a way forward in the problem of how God can at the same time be transcendent and act immanently. From one standpoint God is transcendent because His nature is basically different from all that is generated from Him, but from another standpoint $\mathrm{He}$ is not completely beyond the system in the sense that he directly wills (in the sense of accepting that the world emanates from Him, as explained above) and gives existence to all things. Therefore, it seems that Ibn Sīnā does show that God's relationship with the world is not limited to the emanation process but extends to the whole of the existence process which happens with His knowledge in the sense that each being owes its existence to God. In this way Ibn Sīnā attempts to reconcile the Neoplatonic God with the Islamic one. Although God is absolutely One and transcends the whole world, He is the only giver of existence and from Him comes love, knowledge and goodness. Ibn Sinna also shows that the Intellects are the closest beings to God and therefore receive eternal knowledge, which enables them to produce the world through the existence which God bestows on the world. In this position stands also the Active Intellect who is directly connected with the kind of existence which we have. With this in mind we will show the role it plays in the kind of relationship which is possible between God and mankind. But before proceeding to examine this relationship further, we need to examine one important problem here, which is how God knows individual humans.

\section{God's knowledge of individuals}

After discussing the main characteristics which Ibn Sīnā attributes to God, one more difficulty arises, emerging from the unified nature of God's essence. This oneness, paradoxically, is dynamic and overflowing and has within itself the features of the whole world both as an idea and as a reality; indeed, the world exists only through His knowledge. But the question here is the extent to which God knows each particular individual in this world.

Ibn Sinnā explains that God knows the world because He knows Himself and whatever comes out of Him. ${ }^{67}$ However, this knowledge of God is universal in kind, for as an immaterial being He cannot have particular knowledge, which is dependent on the perceptions of the senses. Ibn Sīna says very ambiguously that "God knows the particular but with a universal knowledge." 68 In order to understand this point, Marmura explains that we need to refer very briefly to Ibn Sīnā's theory of definitions. He explains that the only way to identify a certain particular from others which are under the same species is through sensory experience, for all universal qualities of this "particular" are shared with the species and therefore do not differentiate it from the rest. ${ }^{69}$ In contrast, universal knowledge perceives the qualities - humanity, 
justice or goodness - which are shared among a category of persons without distinguishing any of them.

A universal knowledge would only succeed in identifying a particular when it is the only particular in its species. Therefore, if the species has more than one member, all sharing the same qualities, then the only way of differentiating one particular from the rest of the species is by using sensory description. ${ }^{70}$ If we put, for example, all musicians in one species in which they all share qualities of musicianship such as genius, sensitivity and so on the only way to distinguish one of them would have to be either through describing what he looks like or through his music. Thus, for someone who does not possess any senses, it would be impossible to pick out any one musician. Hence, Ibn Sīnā here shows that identifying the particular comes mainly through sense perception.

Thus, "God is a pure Intellect" means either that He knows himself only, as in the Aristotelian view, or He knows Himself and the world as a part of His knowledge of His own activity, but in a universal way. ${ }^{71}$ Consequently, the absolute immateriality of God does not allow Him to know others and therefore $\mathrm{He}$ is not able to have personal relationships with humans. God is, furthermore, unable to act as judge, as Islamic and especially Mu'tazilite theology stipulate, because he does not know the events of individual human lives.

This is undeniably the most negative aspect of Ibn Sīnā's theology, which Ghazālī severely attacks in his Tahâfut al-Falāsifa, beside the problem of the eternity of the world. Ghazālī rightly criticized the view that God, contrary to what it says in the Qur'ān, would not know every single thing in the world since He can know only through universal knowledge. ${ }^{72}$

However, Ibn Sinnā here draws a picture of a God who is/has absolute goodness, knowledge, love and self-sufficiency in the most perfect sense of these qualities, which puts Him always in the position of giving and never receiving. God is in no need either of the knowledge of others or their love or even their worship. In contrast, the world is always in need of God and forever in the position of receiving and the more it receives from God the more fulfilled the world becomes. In other words, the nature of God as an outpouring and eternal emanation is all that the world needs. Therefore, Ibn Sīnā most probably did not take God's inability to know the particular as a negative, but considered it to be part of the nature of the world.

As a result, God for Ibn Sina has two main faces. On the one hand, He is the Necessary Existent, the one who transcends the whole system by having the unique quality of existence per se. On the other, the mystical face of God is unveiled through the mystery of a willed emanation which provides the world with all that it needs for preserving the good system, nizām al-khayer. God emanates knowledge, love and goodness in His eternal manifestation of His divine light, tajallī. However, the absence of God's knowledge of the individual makes the relationship between God and humans fall within the relationship of God to the world, which suggests that contact with God is not 
through personal relationship but through what God offers to the world: existence, knowledge, love and goodness. Consequently, a relationship with Him can only be achieved in the following ways: (1) through knowledge in its different kinds and (2) through love which is obtained in God's manifestation of Himself, the notion of tajalli. In these two ways the man's task is to prepare himself to receive what God offers to everyone. The aim of this relationship, as Ibn Sīnā shows mainly in the last (Sufi) sections of Remarks and Admonitions, is not a personal relationship with God but a direct

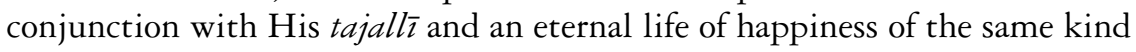
as the ten Intellects enjoy with God. The union with the light of God presents the highest stage of Ibn Sinnā's mysticism as he explores it in the Sufi part of his Remarks and Admonitions.

Having examined the main characteristics of God in Ibn Sinnā's philosophy, we turn now to explore the position of human being which gives a clue to the way in which humans can move to possess the highest knowledge and to stand in the presence of God in His tajalli. First, however, we need to know how Ibn Sinnā perceives the main features of mankind.

\section{The features of humans}

Gutas in his Avicenna and the Aristotelian Tradition considers that Ibn Sīnā discloses human souls according to three different disciplines of philosophy: physics, ethics and metaphysics. First, in his study of physics following Aristotle he explores the different faculties of the soul and explains the process of perceiving material things in an abstract form. He also examines the rational perception of abstract ideas and explains how this is done. Here he already declares that since humans are able to perceive theoretical abstract knowledge, then the nature of the human soul must be immaterial. In the very few places where Ibn Sīnā deals with ethics, he demonstrates that the human soul needs to be delivered from its evil tendency through its connection to the material world. This should be achieved by the help of the religious laws which assist the soul to its salvation through knowledge of the divine world. A third area of disclosing Ibn Sinnās concept of the human soul is metaphysics. Here he unveils the nature of the human soul and its relation to the divine world. In the last part of Remarks and Admonition, however, he declares a further possibility for the human soul: that it can obtain direct conjunction with the divine light and enjoy the happiness of the divine Intellects in their relationship with God. Following this division of the subject, I examine first the different faculties of the human soul, then I move to explore his concept of knowledge and the way in which the human soul is able to perceive abstractions and concepts. Next I turn to his ethical understanding of the human soul in relation to religious knowledge. Finally, Ibn Sinnās concept of the human soul in its relation to the divine world will be mainly treated in the section titled "Relationship with God through His manifestation of Himself, Tajall $\vec{\imath}$ " of this chapter. 


\section{The different faculties of the buman soul}

Ibn Sīnā was the first Arab philosopher who presented a clear and systematic theory of the human intellect and its function. Here he adopts the Aristotelian tradition which considers the body, as matter, to be able neither to think nor to act; thus, it is always passive. The soul, in contrast, is the power which enables the body to act, and human and animal souls are considered to have higher qualities, which initiate activities according to the will. ${ }^{73}$ Ibn Sinnā, following Aristotle, considers that the soul as a power in the body functions through three main faculties: the vegetative soul, which governs the growth and the nourishing of the body; the animal soul, which governs the sensory, imaginative and estimating faculties and, finally, the rational soul, which leads the other two souls and forms human knowledge. ${ }^{74}$ But he differs from the Aristotelian tradition in his conception of the independence of the soul from the body, which gives it eternal life, as will appear in the sub-section titled "Ibn Sinnā's concept of the individuality of the human soul." Thus, the soul, for Ibn Sīnā, is the power which initiates thinking and reflection.

The ability to obtain knowledge about the world with its connection to the divine upper and superior world is to Ibn Sinnā the most important feature of the human soul. Knowledge for him begins by perceiving the particular thing as it exists in reality and going deeper to discover its essence and its relation to other things, and, further, discovering the universal concepts which govern this relation. ${ }^{75}$ This process is achieved through the animal and the rational souls. The animal soul mainly via the senses transfers the particular thing from its external existence to an internal existence as an image in the mind. This material image of the thing will be abstracted and transferred to a notion, like abstracting from the image of a person the notion "human." But further discoveries of this notion, such as that humans are able to think and are a kind of animal, are not obtainable through the animal soul, but rather through the rational soul. ${ }^{76}$

Therefore, when ideas are fully abstracted from their images we no longer speak of Zayd but of the universal qualities which he shares with others not by being Zayd but by being human; now we are dealing with concepts. These concepts are, for Ibn Sīnā, on the one hand connected with the particulars from which they are drawn but, on the other, are in themselves notions leading to a higher kind of knowledge. This last kind is called conceptual knowledge, according to Goodman, but Ibn Sinnā calls these two kinds the particular and the universal, al-juz'` wa al-kullī. ${ }^{77}$ The rational soul, therefore, consists of two kinds of intellect, the theoretical intellect and the practical intellect. The theoretical intellect has the task of seeking universal concepts and the practical intellect arranges the relationship between the rational and the animal soul in conducting human behaviour. ${ }^{78}$ After this short account of the faculties and functions of the human soul in perceiving knowledge, we turn now to examine the nature of knowledge and its connection to the human intellect. 
Goodman explains that knowledge for Ibn Sīnā occupies a place somewhere between Plato's position and that of Aristotle. Plato believes that concepts have an independent existence as divine ideas and we know them through their earthly shadows. Therefore "knowledge can never be acquired (hence, must be innate) since what is unknown will be unrecognizable and what is recognized (and so understood) must already be known." ${ }^{\text {"79 }}$ In other words, if knowing means to know the inner meaning and interior of things, knowing the character that dwells in them, then empirical experience cannot transfer this knowledge. Therefore, knowledge of the divine ideas and their shadows must be imprinted in the human mind and can be known only through the internal process of knowing (or sometimes through remembering).

Aristotle, for his part, believes that ideas have no external existence; they are either in things or in the mind. But he recognized that empirical experience is only the starting point in knowing things; actual knowledge of their universal concepts depends on the process of knowing through the human intellect. ${ }^{80}$

Ibn Sinnā follows Aristotle in considering that empirical experience is the starting point for rational knowledge, but he believes that ideas exist outside the human mind and things, and they, in fact, originate in the mind of God. ${ }^{81}$ They emanate from Him to the different Intellects and then become implanted in things. Wolfson explains Ibn Sīnā's three-fold theory of the existence of ideas:

the universal, Ibn Sīnā says, has three stages of existence: first, before the many (qabl al-katbra) when it is in the wisdom of God, second, in the many ( $\overline{\bar{i}}$ al-katbra) when our minds have yet to abstract it from the particular thing, third, after the many ( $b a^{\prime} d$ al-katbra) when it already exists as intelligible being in our mind. ${ }^{82}$

Ibn Sīnā calls these ideas or notions intelligibles ma'qūlāt. They are of three kinds: intelligibles, which are given to the soul directly as self-evident ideas, which he calls first intelligibles (necessary knowledge). The second kind is the intelligibles which are abstracted from matter and the third kind is intelligibles which do not exist in matter, such as the ideas of goodness or justice. These last two kinds are acquired and therefore Ibn Sīnā calls them second intelligibles.

The importance of the above discussion is to give us an understanding of the nature of ideas as immaterial concepts which the human mind must acquire from outside. The human intellect according to Ibn Sīnā does not possess knowledge in itself but receives this knowledge from the external world. The process of obtaining this knowledge, however, was a subject of debate among Greek thinkers. Thus, we turn here to examine how Ibn Sīnā treated this difficulty.

\section{Ibn Sīnā's theory of inspiration}

Ibn Sinnā's greatest contribution to the Aristotelian tradition lies in his new theory of intuition. In this, he introduces the ability of some to reach 
conjunction with the Active Intellect and to get direct immediate knowledge. This theory developed the understanding of how the human intellect can, on the one hand, move from potentiality where the intellect does not have information, to actuality where it possesses knowledge, and, on the other, how it moves from knowing the particular to knowing the universal.

Davidson explains that this problem started with Aristotle, who identified two states of the human intellect: the state of being, not thinking (called the potential or material intellect) and the state in which the intellect can think all thoughts (identified as the actual intellect). A third phase which stands between these two is the stage where the intellect has intelligibles (rational ideas) but is not thinking of them, called the intellect in babitu. ${ }^{83}$ But Aristotle, as Davidson notes, gives a very obscure description of the way the mind receives the intelligibles, which can be interpreted in two ways: either the faculty of the intellect, which enables humans to discover results, is the highest quality of the human mind, or there may be a transcendent substance, which enters the intellect and provides it with the intelligible thought. ${ }^{84}$

Alexander of Aphrodisias, Davidson goes on, improved this theory and introduced a variation of it. He was the first to attribute the transition from potentiality to actuality to an incorporeal substance which leads the intellect in this process. He named this stage the "intellect from without" by which he meant that there is an intellect which enters the organism from without, becomes the object of human thought and establishes the intellect in babitu which contains the intelligible forms. He identifies this incorporeal substance with the ever-thinking cause of the universe or with the First Cause. ${ }^{85}$ Goodman explains that a Greek philosopher such as Alexander of Aphrodisias did not see any problem in imagining that an incorporeal Intellect enters the human intellect and initiates its activity, where Ibn Sīnā, as we will see later on, considers this to be impossible. ${ }^{86}$ This is probably because Ibn Sīnā makes a clear distinction between the human and the divine Intellect: the former is an intellect which exists in matter and the later is pure, separate Intellect, 'aql-mufäriq. In any case the first one to identify the Intellect which communicates with the human intellect as the Active Intellect in the emanation system was al-Fārābī. ${ }^{87}$

Nevertheless, Ibn Sīnā was the first to show how the human intellect acquires intelligible forms from the Active Intellect, mainly through intuition. This intuition is fully dependent on our own natural intelligence, dhaka ${ }^{8}{ }^{88}$ In Shif $\bar{a}$ ' and Najāt he claims that there are some people who can reach conclusions and results without any process of syllogism or demonstration; such people are able to get results at once, although they are not prophets. He says:

The acquisition of intelligible matter comes about only when the middle term in a syllogism is obtained; this middle term may be obtained in two ways: sometimes through intuition, which is a mental act by means of which the mind discovers, yustanbitu, the middle term all by itself and acumen, dhak $\bar{a}$, being the power of intuition; and sometimes through 
instruction, the origin of which is (again) intuition, since doubtless everything is ultimately reduced to (knowledge derived from) intuition (budūs) handed down by those who first discovered them to their students. ${ }^{89}$

By the middle term, Ibn Sīnā means here the idea which leads to the result. In Remarks and Admonitions he discusses the meaning of the middle term: if we say that $A$ is $B$ and $B$ is $C$ then the result is that $A$ is $C$. We get this result through $\mathrm{B}$, the middle term, which includes in itself $\mathrm{A}$ and $\mathrm{C}$. Thus, the middle term is the intermediate idea, which must lead to the result, or the idea which contains the result. ${ }^{90}$ Consequently, intuitions from the Active Intellect do not reveal the whole truth but give a clue to the truth; the philosopher then works out for himself how to construct his whole system from his intuition. But Ibn Sinnā here does not absolutely devalue the human effort to obtain knowledge, because he considers that the human intellect receives from the Active Intellect only results and conclusions. These, however, need to be integrated in a system and explained in one's own terms. However, when only few people have this power of intuition, the philosopher has to explain his inspiration in a way which others can understand and benefit from. Thus, having intuition is like having a good idea for a book. Writing the book itself still demands great effort.

In any case, Ibn Sīnā considers that the relationship to the Active Intellect is dynamic because ideas come in succession, one form after another, each intelligible giving way to the next. In this way he explains that universal concepts are immaterial and therefore cannot be stored in any material faculty in the brain. Their existence in the rational soul means the actual thinking of them ${ }^{91}$ for they do not remain permanently in the soul but disappear the moment they arrive. Goodman observes that the difficulty of storing ideas in Ibn Sinnā's theory demonstrates the absolute immateriality of ideas. Hence, they can be understood only without the use of images, which explains the real nature of conceptual knowledge, for all that cannot be imagined does not remain in the mind; when we want to remember them we have to rethink them again. ${ }^{92}$

Here also in this context we see the difficulty which Ibn Sīnā must have had in accepting Alexander of Aphrodisias' idea that the incorporeal Intellect enters the human intellect and becomes its object. He gives two main reasons for rejecting such an idea: first, that if it were possible that the Active Intellect became the object of the human intellect, then humans could possess all knowledge at once, which to his mind is absurd and second, that what is absolutely immaterial cannot enter a material organ and become its object without becoming divisible. ${ }^{93}$ These are his reasons for concluding that conceptual knowledge has mainly the function of illuminating the human intellect and enabling it to ascend to higher knowledge, instead of being important in itself.

Knowledge for Ibn Sīnā is, therefore, dynamic and does not have an end or a point where one can measure its ultimate extent. Thus, the relationship 
between the Active Intellect and the human intellect is also a dynamic communication, which has no end nor any point where we can claim full wisdom, because even wise people have to remember their ideas and to rethink them again. Thus, this dynamic connection with the Active Intellect means, for Ibn Sinnā, on the one hand expressing the dynamic need of the human intellect and, on the other hand, the possibility of the dynamic revelation or presence of the divine world.

Finally, we realize here that reason and inspiration are very close together in Ibn Sīnā's philosophy. Humans are able to think and draw conclusions but the human intellect cannot "discover" unknown ideas and conceptions by itself. Ibn Sīnā does not deny that the Greek philosophers themselves also had a struggle to explain how human intellects can discover new concepts about abstract things. Thus, for him it was clear that there was a need to interpret newly the process of human thinking. In our subject, the search for a relationship with God, Ibn Sinnā's inspiration about rational knowledge took him a step towards communicating with the divine world. As noted in the first section, he put human intellect at the bottom of the emanation hierarchy of Intellects, and it seems to me here that he is trying, through the inspiration of the Active Intellect, to come a step closer to knowing God. However, at the end of the present chapter, Ibn Sinnā discloses a relationship in which humans have a direct conjunction with God's presence and, therefore, have an ability to receive knowledge directly from God. Intuition, however, is not the end stage of knowledge but rather its first step.

Next, we explore the higher kinds of intuitions which some humans possess as shown in Ibn Sīnā's theory of prophecy. His concept of prophecy demonstrates another ability of the human soul which unveils further mysterious sides of its nature.

\section{The position of the prophet and the scientist}

In the above discussion we showed that rational and conceptual knowledge for Ibn Sīnā is inspired by the Active Intellect. This knowledge was first in God's mind, then through emanation reached the minds of the Intellects and through the existence of the material world they became imprinted in material things. Therefore, Ibn Sinnā believes that our minds have no access to this knowledge except through inspiration and assistance from the Active Intellect. Hence, knowledge (which originates in God) moves successively from one mind to the next. ${ }^{94}$ But Ibn Sīnā does not consider inspiration or intuition to be the only way of communicating with the divine world; a higher form of communication is through revelation, which is obtained in three ways: through "technical" revelation, through intellectual revelation or through the direct revelation in God's tajalti. Religious revelation or "technical revelation," as Rahman calls it, is the revelation to the prophets in the form of a divine message. Intellectual revelation is also achieved in technical prophecy but is not only restricted to this, as shown below. Revelation which 
is received through having conjunction with God's manifestation of himself, tajalli , is the highest form of revelation, though Ibn Sinnā does not use the word waby in expressing it; this latter kind will be explored in the section titled "Relationship with God through his manifestation of Himself, Tajallz." In this section we will examine the concept of intellectual and technical revelation and next explore how Ibn Sīnā understands and interprets the content of revelation.

Ibn Sīnā in the section on prophecy in Najāt and Shif $\bar{a}$ ' and his treatise Fì Ithbāt al-Nubuwwa talks about two kinds of prophecy. Rahman considers these two kinds to be technical prophecy and intellectual prophecy. Intellectual prophecy comes from a superior human being who is able to reach perfect conjunction with the Active Intellect (or another Intellect) and to receive knowledge in a unified form or as a whole all at once and not as a succession of ideas, as is the case with normal intuition. Technical prophecy is prophecy which occurs through the strong imaginative power of the prophet (the imaginative power is the faculty which transfers the material world into images in the mind). The strong imaginative power of the prophet enables him to receive from the practical angels (celestial souls) a divine message in figurative images; the prophet hears and sees these angels through the strength of his imagination. ${ }^{95}$ In order to explain technical prophecy, Ibn Sinna introduces the function of the celestial souls, whom he also calls practical angels, in communicating religious knowledge.

In his theory of emanation, he describes the celestial Souls as mediators between the Intellects and the heavenly bodies. He says in Najāt that the movement of the heavenly bodies cannot be due to the Intellects, but rather to a close and immanent power which is their final mover, which he calls the celestial Souls. ${ }^{96}$ Celestial Souls emanate from the Intellects and exist in connection with their celestial bodies. In Risāla fí al-Sa'äda, he considers that these Souls are the same kind of rational souls as human rational souls, and Corbin explains that these Souls, on the one hand, have a theoretical rational power through which they receive the emanation of knowledge from their governing Intellects and, on the other, they govern a body through their practical intellect. Their relationship to their Intellects is the same as our relationship to the Active Intellect, but these Souls are superior to human souls because their bodies are made of incorruptible celestial matter. ${ }^{97}$

In short, these celestial Souls, because of their subsisting in matter, are able to have particular knowledge, to know particular earthly events and also to know the causes of events which will happen in the near future. Ibn al-Rushd, however, disagrees that such souls can exist and considers the idea to be absurd. It does seem here that Ibn Sinnā believes in the existence of two kinds of angels: those who have no connection with matter and another lower kind who exist as a superior kind of matter. The latter kind are also able to transfer divine knowledge into figurative images, such as images of what paradise looks like. ${ }^{98}$ These souls, also called angels, are, then, considered as mediators between the divine and sublunary worlds. ${ }^{99}$ In this context religious massages and 
scriptures can be explained as having been revealed to prophets by angels whom the prophet can see and hear through his vivid imagination. Ibn Sīnā here seems to be making a philosophical attempt to explain verbal revelation and to consider it as a natural part of the world system.

Intellectual prophecy, unlike technical prophecy, is considered a sign of very strong intuitive ability. This ability is defined by Ibn Sinnā as the possession of a higher kind of intellect, which he calls the sacred intellect, al-'aql al-Qudsī. ${ }^{100}$

According to Ibn Sīnā, a prophet with technical prophecy must also have intellectual prophecy in order to be able to understand the philosophical truth himself. On this point he does not differ from al-Fārābī who stipulates that prophets should have philosophical knowledge; however, Ibn Sīnā considers that this knowledge can be obtained directly through intuition without the process of learning.

The difference between intellectual prophecy and the inspiration of normal intuition lies not in the prophet's higher intuitive ability, but rather in the nature of the knowledge received. The prophet receives knowledge in a simple unified form, in contrast to the knowledge received through intuition, which comes in a series of steps. ${ }^{101}$

However, the reception of this kind of knowledge is not restricted to prophets, but it seems that Ibn Sinnā includes also scientists and great philosophers. He says in the treatise F $\bar{\imath}$ Ithbāt al-Nubuwwa:

Plato mentions in his book al-Nawāmīs (Divine laws) "He who does not understand the symbols of the prophets will not enter the divine kingdom," and also the highest Greek philosophers and their prophets like Pythagoras and Socrates and Plato were using in their books symbols and allegories and they filled them with their secrets. ${ }^{102}$

Therefore, it seems that the category of intellectual prophets for Ibn Sinnā includes more than the prophets who had a revealed message. The existence of this kind of prophecy, however, is not a necessity for divine providence, as we will show below, but is rather a possibility identical to the possibility that there is someone who has absolutely no intuitive ability. At this point, it is appropriate here to examine religious knowledge and its importance for Ibn Sīnā.

\section{The function of religious knowledge}

In Najāt the discussion of technical prophecy is preceded by Ibn Sīnā's concept of God's providence and the question of human freedom. The reason for this arrangement is that Ibn Sīnā here is making a link between the need for the existence of divine law as a consequence of human freedom and God's providence, shown by divine messages. The discussion in this section will provide another area where Ibn Sīnā studies the human soul in its relation to ethics. We will see in the next part that he consider that the salvation of the 
human soul in its final stages depends on the soul's ascent, in different stages and states, towards a state of annihilation in the presence of God, tajalli . In this context, he refers to the importance of worship as a method of ascending from one stage to the next, as will be demonstrated in section three titled "Relationship with God through His manifestation of Himself, Tajalli." At this stage, however, we will focus on his overall understanding of religious knowledge.

Ibn Sīnā here connects religious knowledge with the concept of divine providence which means that God provides good order, nizām al-khayr, for the world. This providence is not offered for a particular reason but emanates from the absolute goodness of the nature of God's essence which makes all that emanates from Him well ordered. Divine providence, nevertheless, is limited to what is possible, which, according to Ibn Sinnā, means that goodness has its fullness and perfection only in God, and the world can only receive a limited goodness, for the potentiality of the world, the possibility of being or not being involves a certain deficiency. Pure goodness, for Ibn Sinnā, can only be expressed in the Necessary Existence; evil, in contrast, is pure non-existence. The world as the possibility of existence contains in itself, therefore, a certain weakness and deficiency. In the earthly world, this deficiency is experienced in the existence of evil which Ibn Sinnā considers to be a consequence of the nature of earthly matter, which allows change. This evil, however, is only potential in things (the evil in fire, for instance, is its burning) and becomes actual only through human choice and will. ${ }^{103}$

Humans are the only creatures in the emanation system of Ibn Sīnā, Janssens explains, who enjoy a kind of freedom, though this is also determined through different causes influencing the behaviour of the individual, which give a chance for potential evil to be actualized. Thus, only moral evil which is performed intentionally affects the good order of our world. Moral evil is a kind of deficiency in the perfection of human actions, which damages both the individual's perfection and the whole community. ${ }^{104}$

The perfection of the individual is attained through the rational faculty. Deficiency in this perfection occurs when immoral desires prevent the rational faculty from achieving its perfection in knowledge. Therefore, the free will of humans, as Janssens maintains, creates the possibility of increasing moral evil and damaging the divine good order of the first providence. ${ }^{105}$ In the section on prophecy, therefore, Ibn Sīnā talks about second providence. This second providence provides guidance for human behaviour through sending messages or communicating the divine law. In this context Ibn Sinnā explains the need for the existence of a divine law, which humans need for guiding their behaviour as individuals and as a society. Therefore, sending messages and divine laws is a necessity, which God, through His angels, must provide, as Ibn Sīnā clearly explains in Najāt. ${ }^{106}$ It seems here that Ibn Sīnā is influenced by the Mu'tazilite concept of the necessity of some actions of God, as is explained in Chapter 2. 
Religious knowledge, for him, is mainly a form of practical knowledge for it has the two aims of assisting the soul to obtain general knowledge about God (since true knowledge about Him, in his opinion, is obtained through philosophy) and controlling the relationships between individuals in society through the revealed commands and prohibitions of divine law. These commands and prohibitions should set out the relationship between the animal soul and the rational soul, which come under the domain of the practical intellect, for it has the task of controlling bodily desires, bringing the irascible power to maturity and reducing the disturbance to the rational intellect by bodily affairs, as Ibn Sīnā mentions in his study on the human soul. ${ }^{107}$

But it seems that the practical intellect, according to Ibn Sīnā, has two purposes: the first is to guide mature human behaviour, which is important for the community. The second is to reduce the disturbance to the theoretical intellect of bodily desires, which helps individuals in the process of learning. These two aims are precisely the aims of religion; the first aim is realized through divine law, which provides commands and prohibitions leading to the perfection of society. Ibn Sīnā does not show in his writings any interest in interpreting the Islamic Shari $\bar{i}^{-} a$, though in his autobiography he mentions that his early education was in (Isma'îli-Zaydī) jurisprudence. ${ }^{108}$ The second aim of reducing the disturbance to the rational faculty of bodily desires, which is the main interest of Ibn Sīnā here, is accomplished through worship. However, Ibn Sinnā considers that the Qur'ān has two purposes: guiding human behaviour but meantime pointing to the true knowledge of God through many metaphorical and allegorical passages. Here therefore we will examine these two concepts of worship and the metaphorical message of the Qur'ān.

\section{Worship}

Ibn Sinnā, as mentioned above, considers that human souls have three powers. The vegetable and animal powers relate humans to the lower world of the bodily desires, but the rational soul enables them to enjoy conjunction, ittisăl, with the upper divine world. Worship, then, is a bodily training and discipline to submit the lower faculties of the soul to the rational intellect, which directs the body to contemplation of the divine world. He considers prayer the most important element in worship because it attempts to train the bodily faculties to follow the soul and leads the soul to concentrate on the spiritual side of prayer, which, he believes, enjoys the divine effluence. ${ }^{109}$

He explains in The Treatise on the Nature of Prayer that prayers have two aspects, outer and inner; the bodily movements in prayers attempt to control the bodily powers and lead them to follow the spiritual part of the prayer. The spiritual and inner aspect of prayer is its main purpose; in this people should concentrate on and contemplate the presence of the divine world. This very thorough concentration is what the prophet meant, Ibn Sīnā believes, when he said that "the one who prays talks to God." Prayer is thus a spiritual speech 
with God, enabling people to receive the divine overflowing knowledge which establishes a conjunction with the divine world. ${ }^{110}$ This is what Ibn Sīnā calls real prayer. ${ }^{111}$

Thus, prayer is one of the ways of enabling the soul to control the bodily powers, assisting the soul to reach the divine effluence. In this treatise Ibn Sīnā also says that prayers and worship as a whole are ways of obtaining knowledge; he says, "Worship is knowledge, in other words knowing the Necessary Existence by the pure secret and pure heart and the empty soul."112

This means that worship and prayers are educational and allow the soul to prepare itself to receive divine effluence. Thus, real prayer for Ibn Sīnā is a kind of mystical experience, which enables the soul to receive God's emanation and see Him in his heart. ${ }^{113}$ We shall return to this discussion later, in the section on the mystical dimension of his philosophy titled "Relationship with God through His manifestation of Himself, Tajall $\vec{\imath}$ " of this chapter. In his autobiography, Ibn Sīnā mentions that many times when he was trying to find a middle term and had received no intuition, he would go to the mosque to pray and through prayer he could find it. ${ }^{114}$

\section{Hidden meanings of the Qur'ān}

Ibn Sīnā considers that the Qur'ān is verbally revealed; the main importance for him of the celestial Souls, mentioned on page 96, is that they explain verbal revelation. Rahman translates Ibn Sīnā's explanation of verbal revelation in his treatise $F \bar{\imath} I t h b \bar{a} t$ al-Nubuwwa as follows:

Angels have real and absolute being but also a being relative to human beings; their real being is in the transcendental realm and they are contacted only by the holy human spirit. When the two meet, both the human being's senses - internal and external - are attracted upwards and the angels are presented to them in accordance with the power of the man who sees the angel, not in the absolute but the relative form. He hears the latter's speech as a voice even though it is intrinsically spiritual communication (wahy). Spiritual communication is an indication of the mind of the angel to the human spirit in a direct manner and this is the real speech. For speech is only that which brings home the meaning of the addressor's mind (to the addressee's mind) so that the later becomes like the former. ${ }^{115}$

Ibn Sīnā in the quotation above is trying to defend the verbal revelation and to assert that revelation is not the words of the prophet. However, he considers that the Qur'ān presents truth in metaphorical language; he explains that prophets must communicate to the masses concepts such as the unity of God, His uniqueness and unlikeness in symbolic language and in images, which those who cannot understand demonstrative abstract language can absorb. ${ }^{116}$ These images should make difficult conceptual ideas simple enough for 
everyone to understand, though only superficially; but those who are rather more competent will have to discover the real meaning for themselves. ${ }^{117}$

In his treatise al-Risāla al-Adhawiyya Ibn Sīnā attacks the orthodox theologians who do not properly interpret the meaning of the Qur'ān. He was trying to make clear that the knowledge which is presented in the Qur'ān cannot stand alone as truth, although it in no way opposes philosophical truth but is rather its symbolic form. Therefore, religion presents the truth fully covered in images, which simplify philosophical truth for the masses. These are supplied for two reasons: to acquaint them with some facts about God and to disclose the importance of commands and prohibitions. But for the more competent in mind, he says "let me put it to him who will be one of the elect and not amongst the multitude: is the external form of religion usable as an argument in these matters?"118

In speaking thus, Ibn Sīnā is not attacking Islam but rather trying to present its importance and its limits. Arberry in his book Revelation and Reason in Islam, says:

Ibn Sīnā argues at length (in The Treatise of Adhawīyya) that it would have been useless for any prophet to preach a purely spiritual resurrection if the masses of mankind were to be moved to pursue virtue. Physical pleasure and physical pain are what they understand; Ibn Sīnā says: "true happiness and spiritual pleasure are not comprehended by them at all and have no place whatever in their understanding, even though some may make a verbal pretence of it." It proves the superiority of Mohammed to all other prophets, that he painted for men the most realistic and emotive picture of heaven and hell. ${ }^{119}$

Although Ibn Sīnā did not devote any particular treatise to reconciling religion and philosophy, in many treatises he interpreted parts of the Qur'ān and explained the real meaning of its symbols. It seems that Ibn Sīnā considered ta'wīl, in Corbin's understanding of the term, as the disclosure of the real meaning of some parts of the Qur'ān:

Ta'wīl usually forms with tanzīl a pair of terms and notions that are at once complementary and contrasting. Tanzīl probably designates positive religion, the letter of the revelation dictated to the prophet by the angel. It is to cause the descent of this revelation from the higher world. Ta'wīl, is etymologically and inversely, to cause to return, to lead back, to restore to one's origin and to the place where one comes home, consequently to return [to] the true and original meaning of a text. ${ }^{120}$

In this way Ibn Sīnā understood and interpreted the message of the Qur'ān and sought to assimilate Qur'ānic knowledge to philosophical concepts. ${ }^{121}$ As a result the relationship between theoretical rational knowledge and religious knowledge is for Ibn Sinnā represented in ta'wīl. But this relationship is not 
considered in terms of which form of knowledge is higher than the other; Ibn Sinnā believes that they are addressed to different classes of people and each form of knowledge satisfies its own purpose. Religion in its totality is addressed to the ordinary person. Worship, however, is a method for receiving enlightenment, and the metaphorical parts of the Qur'ān guide those who are competent to the further knowledge, which they can attain through intuition. However, if we think in terms of revelation or knowledge which comes directly from God, then we can identify a clear line in Ibn Sīnās theology. All true knowledge for him comes from God either through intuition or through inspiration from intellectual prophecy or through the revelation made to the religious prophets. Thus, Ibn Sinnā demonstrates a continuation of knowledge from intuition to revelation to philosophy and finally to the mystical experience of God's presence where the pure light of divine knowledge will be enjoyed.

In this second part we have attempted to demonstrate Ibn Sīnās great interest in understanding the human soul and revealing its role in the search for higher knowledge. The human soul ascends from knowing the particular to a deeper kind of knowledge which leads the soul to have connection to the divine world. The aim of the discussion above is to unveil Ibn Sinnā's real interest in the human soul as a mediator between earth and heaven and a mediator between his philosophical discipline and his mystical one. It is the rational human soul which can receive deeper knowledge, intuition and revelation. But it also leads Sufis in their ascent to mystical knowledge and is the link between God and humanity, as we want to show in the next part. Thus, the famous Hadith "knowing your self is knowing your God," in Ibn Sinā's philosophy is an actual statement in which he proves that the human soul is the pass through which we enter eternal life. At this point, we can safely say that we have arrived at a vantage point from where we are able to perceive Ibn Sīnā's understanding of who God is and the nature of the human soul as the link by which mankind may enter the divine world. The next step here is to embark upon our main purpose in this chapter of exploring Ibn Sinā's concept of 'ish $q$ and unveiling the importance of the mystical dimension of Ibn Sinnās philosophy. Thus, in the next section we will explore the profound face of the relationship with the divine which allows humans to obtain a direct conjunction with God's manifestation of His presence, His tajallī.

\section{Relationship with God through His manifestation of Himself, Tajallī}

"He who knows himself knows his lord." By the time of Ibn Sinnā, this saying had become a favourite Hadīth of "intoxicated" - i.e., pantheistic Sufis, for its suggestion that the soul is to be identified with God. But philosophers and theologians of more sober stamp shied away from the idea that the inner self is divine, preferring another Platonic suggestion that the mind knows God through an inner likeness. ${ }^{122}$ 
Goodman, in the quotation above, points out the extent of the problem of the soul and its connection with God. In the Sufi experience, the soul knows "the likeness," but for Ibn Sīnā, as Goodman emphasizes, it is only the intellect which knows God in some analogous manner. However, in Ibn Sīnā’s Treatise on Love, he clearly makes a link of likeness between God and human souls through love. Love flows from God to all things and constructs a tie between all souls and God; when humans come to the stage where the purified soul acknowledges this divine love they are at the first stage, maqām, of the ascent to making conjunction with the divine light. Ibn Sīnā then pursues this conception in His last work Remarks and Admonitions, emphasizing the likeness between God and human souls by the virtue of the nature of their soul, which always yearns towards the divine love. This is what saves them from this world and guides them to enter the divine presence in His tajalli.

Thus, this section will attempt to introduce part of Ibn Sīnā's theory of knowledge which differs altogether from his theory of intuition. Knowledge about God here will not be acquired through learning but through ascending different stages which lead to the meeting with God and therefore to acquire knowledge of Him through vision. Love is the mediator which links the soul with God in its higher search for vision.

For this purpose I will first examine the nature of the soul from a certain angle: the possibility of its separation from the body and its independence of it. The aim here is to show that Ibn Sinnās theory of the substantiality and the individuality of the human soul is linked to his mystical search for happiness through ascent to the point of eternal conjunction with the divine light. Second, this part will examine the development of his concept of love, 'ishq, and, finally, we will follow the ascent of the soul in its ultimate relationship with the divine presence, tajallī.

\section{Ibn Siña's concept of the individuality of the buman soul}

The human essence consists of a body (human matter) and a human soul (the human form). Ibn Sīnā in his study of the human soul describes the soul-body relationship. As mentioned in the sub-section titled "The different faculties of the human soul" in this chapter, form for Ibn Sinnā is the power which initiates activity in matter and in the case of the souls of humans and animals this activity is constructed according to a will. This makes animal and human souls a special kind of form. ${ }^{123}$

The first problem Ibn Sīnā faces here is if the body and the soul are in a sense composed of matter and form, what kind of relation do they have to each other. Before dealing with the answer to this question, however, we should refer briefly to the history of this problem.

Aristotle considered the human soul to be a high type of the form which exists only in connection with matter (body). For him, as Rahman explains, the soul is "an immanent principle which organizes the body and gives it its specific character and makes it what it is." ${ }^{124}$ He attributed rational knowledge to the 
soul and held, like Plato, that the body is a mere instrument employed by the soul. At the same time he limited the existence of the soul to the existence of the body. This forces the conclusion, Rahman points out, that he had an inconsistent view of the relationship of soul to body because if the soul is a substance which is superior to the body, then its existence should not be restricted to the body's existence. ${ }^{125}$

The principle of the soul as immaterial and separable from the body was the centre of Plotinus' psychological teaching. But for him, as Rahman noticed, the crucial point was mainly to define the soul-body relationship in order to combat other groups who considered the soul as the inseparable form of the body. ${ }^{126}$ Goodman explains that Plotinus argued that the body cannot think and therefore its relationship to the soul is merely instrumental. This argument, however, did not convince the Muslim mutakallimunn, who did not see a logical ground for this claim. ${ }^{127}$ For them the body has great importance, for it will have eternal life in paradise.

In order to prove Plotinus' claim, Ibn Sinnā concentrates on the nature of conceptual knowledge ${ }^{128}$ and argues that it cannot be acquired by a body, as we will show below. But Ibn Sīnā's interest was not merely to defend the separability of the soul from the body but mainly to prove its individuality, as Goodman shows in his book, Avicenna. ${ }^{129}$ In order to approach his understanding of the individuality of the soul we examine in turn its immateriality, its independence and, finally, its individuality.

Ibn Sinna proves that the human soul is immaterial through explaining how the rational soul perceives universal knowledge. Universal ideas are immaterial and indivisible because they are either abstract by definition - time, existence, justice and goodness - or they are abstracted from matter, for example, the idea of eternity, which is generated from observing a very old tree, or of fear, when we see a huge desert, etc. Thus, if the soul is a material substance in the body, or if the body itself can think, ideas must be diffused into all parts of the body and, consequently, they will never be perceived as abstract unities forming one idea. Therefore, if the human soul perceives universal knowledge, Ibn Siña insists, then it must be an immaterial power in the body which enables humans to reach this higher knowledge. ${ }^{130}$

Another proof of the immateriality of the soul is: if the soul is a kind of matter, and matter in the Aristotelian tradition cannot think, then the soul could not construct and discover knowledge but rather would only be affected by knowledge, for example, as the material body is only affected or passive, $q \bar{a} b i l$, which to him is absurd. ${ }^{131}$ The importance of this point is that it forms the basis on which Ibn Sinna later builds the idea that the life after death is only spiritual. The importance of the second life lies, for him, in the higher stages of the soul which enable it to have full happiness in being conjoined with the manifestation of God. Therefore, this kind of life demands not a body but a high quality of soul, as is shown below.

Some Muslim theologians, such as Ibn Qayyim al-Jawziyya (AD 1292-1350), Goodman points out, considered that the soul is a kind of body, in order to 
prove the importance of the body in life after death. Ibn Qayyim says: "it (the soul) flows through them (bodily organs) as sap flows in roses and oil in olives." 132

That the soul is an independent element in the body was clear for Ibn Sīnā through his observation that only the body with its senses becomes old, but not the soul. The knowledge of an old person, Ibn Sīnā believes, can be even better than that of a younger person. ${ }^{133}$ For this reason, Ibn Sīnā explains, we recognize our selves as an "I," a self which perceives everything through one collective power. ${ }^{134}$ Consequently, the soul, for Ibn Sīnā, is an independent power in the body through which people can at all stages of their lives perceive knowledge.

Ibn Sinnā proves the individuality of the soul through his famous example of the floating man. He imagines a man who is cut off from any relationship with all his five senses flying in the air without even feeling this air, but who still would know himself. ${ }^{135}$ He says:

Suppose your being to have been just begun. You are of sound and capable intellect, but your bodily parts are so disposed that you cannot see them or touch your limbs or organs; they are separated from one another and suspended for the moment in thin air. You would find that you were conscious of nothing but your own reality. ${ }^{136}$

Ibn Sīnā seeks in this example to demonstrate that the soul is not only an independent power but also an individual which knows itself without connection to the body. It also discloses that the rational faculty of the soul is a power comprehended within its own merits and absolutely independent of the body. This comprehending power is able to think even when no sensory information is provided. He identifies this power with the soul and says that it can unveil the individuality of the person and recognize him as a unique self. ${ }^{137}$ The example above proves the possibility of the soul's having a full awareness of itself and of its knowledge without reference to any material body; consequently, it can reach the level of the divine Intellects as a substantial essence with the eternal activities of intellection and love. This becomes clear in the Sufi part of Remarks and Admonitions when the human soul ascends to the point of the same kind of love as the Intellects.

However, although the soul here seems to have a divine element which gives it substance and an eternal future, Ibn Sīnā in Najāt and Shifáa' is careful to explain that the soul does not have a pre-existent history, but comes into existence only when a body does. ${ }^{138}$ It also exists in the human body as a material intellect which gets its experience and knowledge only within the earthly existence of the soul. Moreover, the happiness of the soul after its separation from the body will depend mainly on its earthly intellectual activity, which it experienced in the body. He explains in Remarks and Admonitions that after death the soul can only continue what it accomplished in its earthly life, gaining only higher universal knowledge. But souls which 
did not obtain universal knowledge before will either be satisfied with the enjoyment of their little rational pleasure or will bear the eternal suffering of being ignorant. ${ }^{139}$

Thus, the soul starts with no knowledge and goes into eternal ascent towards the First Cause. It seems here that Ibn Sīnā had a clear understanding of the human soul at quite an early stage and made hardly any substantial change in it. He mainly treated it in two different contexts: its rational activity and its substantial and individual relationship to the divine world. In Remarks and Admonitions, however, he unveils a third context in which the human soul can be studied, that is, the process of its ascent from the material world to encounter the divine light without mediators. In this context, Ibn Sīnā reveals his own mystical understanding of the human soul's journey. Before reaching this stage, which is approached through love, we will here first examine Ibn Sinnā's understanding of love, not as the usual Arabic term mahaba, but through his usage of the mystics' term 'ishq.

\section{The concept of love, 'ishq}

The concept of divine love, 'ishq, can be traced in Ibn Sīnā's philosophical works as well as in his mystical ones. Ibn Sīnā describes God in Shif $\bar{a}$ ' and Najāt as pure goodness and illustrates that this goodness is absolute perfect existence, while evil is absolute non-existence. ${ }^{140}$ The One perceives Himself as absolute goodness and beauty, not through the imaginative power, for $\mathrm{He}$ is free from matter, but rather through pure Intellect. ${ }^{141}$ God as pure Intellect knows Himself and the goodness of His essence; consequently, this knowledge is also expressed in loving and adoring His essence 'āshiq wa ma'shūq, as Ibn Sīnā describes Him in Najāt. ${ }^{142}$ Here he compares God's love with ours: "we love and strive for what is good, beautiful and perfect, therefore God's love can be mainly directed towards His essence which is the perfection of beauty and goodness." ${ }^{143}$ Bell maintains that Muslim theologians in general adopt the belief that God loves His essence. ${ }^{144}$

In Najāt Ibn Sinnā also explains the relationship of being attracted and the yearning between the celestial Souls and their governing Intellects and between the heavenly bodies and the celestial Souls. This yearning is towards perfection, which for the heavenly bodies is the persisting of existence and for the celestial Souls and the Intellects is the love of the perfection of God, ${ }^{145}$ which is referred to later on in The Treatise on Love as the experience of the manifestation of the Necessary Existence. Thus, Ibn Sīnā in Najät and Shif $\vec{a}$ ' is giving a basis to the concept of love which he expands in The Treatise on Love and in Remarks and Admonitions and other mystical works.

Ibn Sīnā in The Treatise on Love demonstrates that love is that which keeps the whole world in existence. Each thing yearns towards what is higher than itself: matter to form, the soul to the Intellect and the Intellect to God. This kind of 'ishq is instinctive and naturally planted in all these things in order 
to keep them in existence by their striving towards perfection, which in this case is the maintaining of existence against non-existence. ${ }^{146}$

The second kind of 'ishq is the voluntary and chosen 'ishq which strives also toward perfection of being, but perfection here is not only maintaining existence but striving for the highest benefit possible. This kind of 'ishq is the ' $i s h q$ of the animal faculty of the human souls for nourishment, a beautiful state of mind and for social and political power. At the same time, it is also the 'ish $q$ of the different powers of the intellectual soul towards the benefit of maintaining their existence in eternal happiness. ${ }^{147}$

The highest kind of 'ishq, however, is the 'ishq of beauty and goodness for its own sake without expecting any return. This kind of ' $i s h q$ is instinctive and always active in the governing Intellects and is the striving of the human and celestial souls. ${ }^{148}$ In Remarks and Admonitions, however, Ibn Sīnā explains that the human souls, while they are in the body, remain at the stage of yearning while the Intellects have full satisfaction in their love for God. ${ }^{149}$ However, some elected Saints will be able through spiritual exercises to reach the kind of love which the divine Intellects enjoy, as will be discussed in the next section.

All these kinds of 'ishq are poured by God upon all beings, and, therefore, they share the love which God has towards Himself. Ibn Sinnā explains that the implanting of this love is part of the divine providence for preserving good universal order. ${ }^{150} \mathrm{He}$ also makes an interesting comment on two passages of The Treatise on Love that the existence of things is due to this love, and that love is the real attribute and content of God's essence. In the first he explains that "each of the governed beings has a natural yearning and an instinctive love and in this love is necessarily the reason of its existence". ${ }^{151}$ In the second passage he says:

there is no certain distinction between the divine attributes in the Essence, therefore Love is identical with the Essence and the Existence (al-'ishq buwa sarīh al-dhāt wa al-wujūd) I mean in the First Goodness. Therefore the existence of all being results either because of a love in them or because the love and their existence are identical (as in God's case). ${ }^{152}$ This indicates that no beings are without (that is, free of, empty of) this love. ${ }^{153}$

In this passage he explains that since the Essence and Existence of God are identical, divine Love is both Essence and Existence. Love then is the highest of the divine attributes and defines God's real essence. Since God's essence is love then whatever comes from Him must include love. It seems that Ibn Sinnā wants to use this idea to explain that everything must have love in some way or another implanted in its existence. This love is all being and is probably implanted through the third element which bestows an existence to matter and form and comes directly from the First of all beings. This is Ibn Sīnā's new contribution to Aristotelian philosophy, as outlined in the sub-section 
titled "God's relation to the world" earlier in the chapter. If this third element flows directly from God, then in this element must be implanted some of the divine characteristics such as love, goodness and intellection in different proportions. This discloses a resemblance between God and the world, whereby God is the source of certain qualities. Therefore nothing has perfection, goodness or intellection from itself; each perfection in the universe is a reflection of God's. ${ }^{154}$ This, Netton explains, is the consequence of the emanation process:

in one sense emanation ( fayd) and love ('ishq) may be viewed as two sides of the same channel of cosmic movement: all things come from God by a process of necessary emanation and all things desire to return to God by a process of innate or necessary love. ${ }^{155}$

Nevertheless, the unlikeness between us and God is due to the fact that our existence is mixed with potentiality and matter, which Ibn Sinnā considers as holding the possibility of evil and deficiency, as suggested in the sub-section titled "The function of religious knowledge" earlier in this chapter.

However, the attainment of pure love which is achieved by some elected human souls seems, from the following passage in The Treatise on Love, to depend fully on previous true knowledge:

The divine souls of the humans and angels do not deserve to be called divine unless they win knowledge of the pure Goodness, because perfection will not be attributed to these souls unless they perceive the causes of the intelligibles. And there is no way of perceiving them unless it is preceded by the knowledge of the true causes, especially the First Cause. ${ }^{156}$

This love, therefore, is not simply a feeling but is based on knowledge; the lover knows what he/she loves and the purpose of this love. Ibn Sinna here asserts that if this love is directed towards the inner essence and not merely the superficial aspects of the object loved, then a knowledge of this essence and its relation to the lover must precede it.

It seems that Ibn Sinnā's concept of the identification between the essence and the existence of God entails that pure goodness, Intellect and love are also indistinguishable. Therefore, he comes to the recognition that rational and conceptual knowledge leads to the realization of goodness, which generates love, and that these three must exist together. Knowledge which does not recognize goodness and does not lead to love seems not to be true knowledge; "he who prefers knowledge for the sake of knowledge professes belief in knowledge. He who finds knowledge, yet as if he does not find it, but finds its Object, plunges in the clamour of the arrival."157

However, it is not clear from this treatise whether God, according to Ibn Sīnā, loves other than Himself. In Najāt he explains that since love is directed 
to one's perfection then God's love must be directed to Himself. But at the end of The Treatise on Love he says:

the true lover is to receive His Manifestation, tajall, and this is the divine souls' true reception of Him. Therefore it is possible that they are His lovers and to this refers the Hadith which God has said: "If the servant did this and this he will love me and I will love him." 158

In this passage Ibn Sinnā declares that it is possible that the One loves certain souls who stand in a direct relationship with His manifestation. However, the love of the human soul and the celestial Soul and that of the different Intellects is experienced through God's manifestation of Himself which Ibn Sinnā refers to in this and other treatises, in Remarks and Admonitions and in his commentary on The Theologia Aristotelis (Kitāb al-Inșāf) as tajallī. This tajalt $\bar{\imath}$ seems to be a great light that is always shining and that illuminates the Intellects which receive it so that they first recognize their reality and their individual self and then they realize God as the first cause of everything. The next section will explore this concept and present its connection to the Sufi path which Ibn Sīnā traces in Remarks and Admonitions.

\section{Relationship with God's tajallī}

In the sub-section titled "Ibn Sīnā's concept of the individuality of the human soul" earlier in this chapter we saw how the human soul, according to Ibn Sinnā, has the possibility, when it obtains conceptual true knowledge, of reaching a level at which it knows itself, in a similar way to the divine, separate substances or Intellects. In the sub-section titled "The concept of love, "ishq" earlier in this chapter we examined Ibn Sinnā's view of the communication with the divine world through love. In this section, we want to link Ibn Sīnā's concepts of 'ishq and the substantiality of the human soul with his mystical method of reaching the ultimate truth through experiencing the tajalli of the divine presence.

In the last part of Remarks and Admonitions ${ }^{159}$ Ibn Sīnā presents a further way of communicating with the divine world, which is different from the way he introduced in his study of the human soul in the previous works Shif $\bar{a}$, and Najāt. First of all, we notice that the person who receives this kind of relationship is introduced as a knower, 'ārif.

A knower for Ibn Sīnā is probably one who possesses universal knowledge in the process mentioned in the sub-section titled "Ibn Sinnā's theory of inspiration" earlier in this chapter. In addition, he explains here that a knower is one who seeks the truth, not as a means for reaching another goal, such as a better life after death, but as an ultimate aim in itself. This is for him the highest pleasure. The knower is not like the ascetic or worshipper who wants to attain knowledge of God in order to have a better second life, as if they were bartering the pleasure of this world for the double pleasure of the second 
life. ${ }^{160}$ The knower, in contrast, can use mysticism and worship as means of reaching the truth but not as aims in themselves. The knower, therefore, is "the one who disposes his thought towards the sanctity of divine power, seeking perpetual shining of the light of the truth into his innermost thought."161

The ultimate aim of the knower here seems to be different from ordinary knowledge. Knowing through the theoretical intellect, as we showed in the sub-section titled "The different faculties of the human soul" earlier in this chapter, is knowing through objects. These objects are the intelligibles which the mind hopes to reach through intuition. The aim of most kinds of knowledge is to know the unknown. But the hope of the knower here is to encounter "the illumination of the light of truth." Ibn Sīnā makes clear here that:

he who prefers knowledge for the sake of knowledge professes belief in knowledge. He who finds knowledge, yet if he does not find it, but finds its Object, plunges into the clamour of the arrival. Here there are steps no fewer in number than those which have preceded... He who desires to know these steps must move gradually until he becomes one of the people "witnessing" not speaking, one of those who arrive at the truth itself and not those who hear its traces. ${ }^{162}$

Thus, the first conclusion we reach is that Ibn Sīnā is now not using "knowing" in its usual sense of knowing through conjunction with the Active Intellect which illuminates the human mind with knowledge of the intelligibles; his approach here is different. The ultimate aim here is not to disclose the unknown intelligibles but to have conjunction with the divine light. The purpose of this section, therefore, is to examine Ibn Sīnās concept of the divine light, or God's manifestation of Himself, tajalliz; disclose the method of attaining the vision of divine light and, finally, look at the possibility of union with the Necessary Existence.

\section{The definition of tajallī}

In The Treatise On Love Ibn Sinnā explains that the highest stage of love is realized in the tajalli, God's manifestation of Himself. This manifestation is what the Sufi experiences at the end of his spiritual exercises in the ascent of the soul towards the divine world. It is considered to be a perpetual possibility which is always becoming actual, expressing the capacity of God to be eternally manifest. ${ }^{163}$

The concept of God's being manifest, as Jenssens explains in his article "Ibn Sīnā on Creation," appears in some treatises of Ibn Sinnā such as The Treatise on the Nature of Prayer and the treatise On the Commentary of Sūrat al-Falaq, The Treatise on Love and in his Commentary on The Theologia Aristotelis. In these works one can trace three usages of this word tajalli expressing three different meanings. In his Commentary on The Theologia Aristotelis, Jenssens points out, Ibn Sinnā uses tajallı̄ to show that God is only 
knowable through the manifestation of Himself to the divine Intellects which they, in turn, communicate to human souls. In this manifestation they recognize their individual self and the existence of all things. This manifestation is like a sparkling light overflowing from the First and is mirrored on the intellectual souls: "When the First principle manifests (yatajallā) itself to them (the Intellects), they comprehend It, they comprehend themselves, and they comprehend everything (situated) in the further degree (of being)."164

The second meaning of tajallī is the emanation of all things. Ibn Sīnā says in The Treatise on Love that all things come into being through the manifestation of God: "[I]f He did not manifest Himself there would not have been any existence." ${ }^{65}$ He also explains in his commentary on Surat al-Falaq that infilāq means the breaking out through darkness into light; this is the light of God's presence. The infilāq through God's light here is the source of existence for Ibn Sīnā which broke out of the darkness of non-existence and caused existence. ${ }^{166}$

Tajalti, as Jenssens explains here, seems to be connected with the concept of the emanation of light, fayd al-nūr, which The Treatise on the Nature of Prayer calls the source of knowledge. In this treatise Ibn Sinnā explains that, in the form of inward prayer in which the person fully concentrates on his desire to have conjunction with the light of God, it is possible to experience directly the pouring out of light faydān al-nūr from the divine presence. ${ }^{167}$ This image represents the concept of tajalli , described above, as the light of the immanent Divine Presence. Here, in the treatise Ibn Sīnā shows that this emanation of light in prayer illuminates the human intellect with knowledge of the nature of God and he considers it to be a kind of vision of God through the heart. ${ }^{168}$

In The Treatise on Love he also demonstrates that in the tajalli God's love emanates from Him directly to the Intellects which are the only beings standing in direct conjunction with the manifestation of God. ${ }^{169}$ Human souls can receive this love through its emanation from the Active Intellect. ${ }^{170}$ However, in Remarks and Admonitions he declares that some human souls can experience direct conjunction with the divine light.

Hence, tajallī means the light and the glory of God, which causes existence, and the emanation of knowledge, goodness and love. It seems that Ibn Sinnā in his concept of tajallī discloses a direct relationship between God and the world. In His tajallī God on the one hand breaks through darkness by causing existence and on the other makes Himself known through the pouring out of knowledge and love. His nature is creative in eternally pouring out and emanating, the emanation being characterized by His nature. The closest creatures to Him are the ones who enjoy these qualities of the Intellects and some human souls. ${ }^{171}$ Netton points out a text from Hayy Ibn Yaqzān which describes beautifully this tajallī as a great light which attracts everything towards It (Him):

When one of those who surround His immensity undertakes to meditate on Him, his eye blinks with stupor and he comes away dazzled. Indeed, 
his eyes are almost ravished from him, even before he has turned them upon Him, it would seem that His beauty is the veil of His beauty, that His manifestation is the cause of His Occultation, that His epiphany is the cause of His Hiddenness. Even so it is by veiling itself a little that the sun can be the better contemplated; when on the contrary, the heliophany sheds all the violence of its brightness, the sun is denied to the eyes, and that is why its light is the veil of its light. ${ }^{172}$

\section{The method of obtaining the vision of the divine light}

Ibn Sinna explains, at the beginning of the ninth class of the Sufi part of Remarks and Admonitions, that the motivation behind the mystical experience of the knower is his intense desire to witness the divine light. This can only happen when the lower powers of the human soul, imagination and estimation, turn away from bodily desires and sensible impulses and direct their attention to innermost thought. ${ }^{173} \mathrm{By}$ innermost thought (or the tranquil soul) Inati analyses:

Ibn Sīnā is here referring to the theoretical intellect as follows: "to render the commanding soul obedient to the tranquil soul so that the power of imagination and that of estimation will be attracted to the ideas proper to spiritual affairs, abandoning those ideas that are proper to base things. The third is to render the innermost thought sensitive to attention."174

It is possible here to consider that the tranquil soul resembles the rational soul, because in his explanation of the process of knowledge Ibn Sīnā makes clear that the rational soul is the highest faculty which the human soul possesses. The innermost thought seems to be the highest faculty (the theoretical Intellect) of the tranquil soul. Here, however, we notice that Ibn Sīnā uses different terms unlike those for describing the usual process of knowledge; the reason is his desire to describe a different approach to the divine world. Thus I am inclined here not to consider the tranquil soul as identical to the rational soul, rather it includes it. All faculties of the soul should pay attention only to the tranquil soul. This can be achieved, Ibn Sinnā explains, through worship, which leads the different faculties of the soul to concentrate on the divine world and receive the inflowing light, to which Ibn Sīnā referred earlier in his approach to worship. The innermost thought of the tranquil soul contemplates the quality of the Beloved. The desire behind this contemplation is for "sensitive thought and pure love." ${ }^{175}$ When the soul follows these steps, it arrives at the first stage of witnessing through living lightning which dazzles the knower.

Hence, the human soul can, through spiritual exercises and intense desire, gain a sight of and be conjoined with the divine light. This can take place on earth, not through assistance from the Active Intellect, but by following the 
mystical ascent which depends on ascetic life, worship and a deep desire to witness the beloved. This process here resembles the stages which lead to the purification of the soul, according to the mystical direction of many Sufis, in order to prepare these worshippers to reach the states of annihilation and union, as will be elaborated on in Chapter 4 on al-Ghazālī.

Ibn Sinnā is thus disclosing here a different approach to the divine world. This approach reveals his belief that there exist some persons (knowers) who can through spiritual exercises reach the enjoyment of observing the divine manifestation directly, such as is enjoyed by the Intellects. Gardet explains that the aim of Ibn Sinā's mysticism is the ascent of the human intellect to a rank similar to that of the divine Intellects. ${ }^{176}$ The illuminated human soul is able to reach the level of the divine Intellects where it can receive the light of God without any veil. Gardet considers, however, that this new approach is a further continuation of knowledge in the normal sense which is obtained through the Active Intellect, the main difference being that here knowledge comes through direct conjunction with the light of God. ${ }^{177}$ But it is clear here that the ultimate aim of this mysticism is not knowledge but mainly the enjoyment of the manifestation of God in His tajallī. Eternal happiness here is not merely a rational pleasure, as one understands the term from his discussions of knowledge in the normal sense, but is rather the happiness of enjoying the eternal observation of God's tajallī This, we believe, is quite similar to the Gnostic Sufism of Junayd or Bisțāmī, which is to be discussed in Chapter 4 on al-Ghazālī. In addition, Ibn Sīnā here shows that some souls are able to absolutely transcend their bodies and everything around them through the power of spiritual exercises. The capacity to reach such a relationship is utterly different from the ability to know in its conventional sense.

Therefore, the ultimate aim of Ibn Sīnā in his work Remarks and Admonitions is to add the final hope of the human soul, that of experiencing tajallī. Ibn Sīnā in this part of Remarks counts nine stages in the experience of this tajallī starting with moments of conjunction which come as lightning flashes, then these moments increase as one persists with the spiritual exercises to reach a state of conjunction whenever the knower wishes. The soul of the knower grows to reach the state of relating all its earthly experience to the ultimate Truth so that it becomes calm and realizes the vanity of whatever is around it except the Truth. The highest stage is the full annihilation of oneself in the Truth when the soul arrives at true conjunction. ${ }^{178}$ The knower here becomes "one of the people of witnessing and not speaking, one of those who arrive at the Truth Itself."179

\section{The possibility of the soul's union with the divine light}

At this stage a question arises, whether the soul in Ibn Sīnā's mystical philosophy loses its individuality and melts in with the Divine at the moment of conjunction. Before answering this question it is appropriate 
here to adduce the discussion which Morewedge presents in his two articles "The Logic of Emanation and Sufism in the Philosophy of Ibn Sinā," Parts 1 and 2. ${ }^{180}$ Morewedge in these two articles seeks to prove that Ibn Sīnā presents a mystical dimension in his system which leads to a union with the Necessary Existence. He explains that there are three different ways in which persons may be related to God: in harmony, connection or union. These three ways are the result of three different relationships between God or the ultimate Being and the world. The first relationship is a relationship of creation: God has created the world at a certain time for a certain purpose. Therefore there is the possibility that God existed when the world did not. Mankind in this theory relates to God in terms of harmony which does not allow a union with the divine who is basically different from the creature. This harmony depends on the mediator of the prophetic soul in the person of Muhammed. This is the religious version of this relationship. ${ }^{181}$

The second kind of relationship between the unlimited Being and the world is a relationship of co-existence. This is the philosophical Aristotelian version in which matter is co-eternal with the Prime Mover, whose role is only to cause the movement and actualization of matter. Thus, matter is neither created nor emanated from any being, but is eternal. The relationship of persons to the ultimate Being in this system is a relationship of connection. Connection here means, for Morewedge, having God-like activity. This activity in the Aristotelian tradition is the power to experience entities as "eternal truths," "universals," "moral directives" and so on. The human soul here can have similar activities to the Divine, mainly in obtaining the same kind of knowledge. ${ }^{182}$

The third relationship between the ultimate Being and the world is emanation. The First emanates the Universal Intellect which in turn emanates the multiple world, either through the Universal Soul, as in the system of Plotinus, or through a number of Intellects, as in the emanation theories of al-Fārābī and Ibn Sīnā. The relationship between persons and the One in this system can develop to the point of returning to the origin and union with the First. This theory, for Morewedge, is the main theory which has close affinity to Sufism in its ultimate hope of union.

We notice here that Morewedge connects Sufism mainly with the experience of union and return which derives from the belief that the human soul has great similarities with the ultimate Being because in some way it has emanated from It. This mysticism is related to Plotinus' system or similar ones in which the human soul is related directly to a Universal Soul in the trinity of the One, the Universal Intellect and the Universal Soul. The human soul in this system hopes to return to its origin in the Divine Universal Soul. However, in the emanation system of Ibn Sīnā the human soul is related only to the Active Intellect and is quite remote from the Necessary Existence. Thus, this idea of returning, as Gardet notes, is not expressed in any part of the philosophy of Ibn Sīnā. ${ }^{183}$ 
Our concern here, however, is to examine briefly whether Ibn Sinnā's philosophy allows a union between the Necessary Existence and the human soul. Goodman devotes a long section in his book, Avicenna, to explaining the impossibility of union in Ibn Sīnā's philosophy and mysticism.

The problem of identifying the knower with the known, Goodman explains, started with Plato, who said that knowing the like by the like, which means knowledge, is a unification of the subject and the object. The mind also for Aristotle is what it knows; thus, if the mind knows God, this means thereby in some sense that the mind becomes God. Also Alexander of Aphrodisias believes that the mind which has divine knowledge is divine, and finally Porphyry believes that when the Active Intellect actualizes the human intellect it becomes at the same time its subject. ${ }^{184}$ Hence, the union of the knower with what he knows and finally that of the soul with its source is a profound Greek notion.

But Goodman shows that Ibn Sīnā rejects this belief; in his works he criticizes Porphyry and Alexander and shows the absurdity of thinking that the human intellect can become at any point the Active Intellect. In Remarks and Admonitions, according to Goodman he asks, "How can a subject know anything if in every act of knowing it loses its own unique identity?"185 Goodman sums up his opinion:

Ibn Sinnā took to be the very goal of rational mysticism, the attainment of individual immortality. Nor did he accept Plotinus' teaching about the divinity of the soul. Rather he used the full rigor of Neoplatonism to discipline the idea that the fulfilled human intellect is (in the language of the more sober mystics) in contact ittișal with the Divine. ${ }^{186}$

We can acknowledge the impossibility that the soul loses its individuality through the logic of his system: Ibn Sīnā's hierarchical system emphasizes the role of each being within the system, which is unchangeable; the human intellect cannot become a divine Intellect nor can the divine contingent Intellect become the Necessary Existence. Ibn Sīnā argues in his discussion of the divine providence that the good order of the world is that each being in the system must remain in its category. ${ }^{187}$ Each being belongs to a certain species with certain qualities which differentiate it from others. In such a system it is nearly impossible that one being can absolutely resemble another because their basic natures are not only different but also unchangeable.

Ibn Sinnā, also, emphasizes that God is the only Necessary Existence which contains no duality, whereas all other beings in the world have the duality of essence and existence. The origin of all beings is the non-existence which all have in themselves; their existence is borrowed from the only Necessary Existence, as he clearly explains in Najät. ${ }^{188}$ There is not even a resemblance between the human soul and the Active Intellect, which Ibn Sīnā considers as its source. As he clearly argues against Porphyry in Remarks, the human intellect starts as a material intellect free of any knowledge and if its 
conjunction with the Active Intellect means union between the two then the human intellect would know all knowledge at once, which is absurd. He says:

Know that the saying that a thing can become something else, not on the basis of a change from one state to another or on the basis of being combined with another [whereby] a third thing appears, but on the basis that it was something and it became something else, is a literary saying which is absurd. ${ }^{189}$

At the end of Remarks and Admonitions Ibn Sinnā is careful to explain that the knower in the highest stage of the approach to the truth has full awareness of himself; he says: "At the time of arrival, he is either pre-occupied with the Truth to the exclusion of everything else, or he is open to both sides due to the broader range of his power." ${ }^{190}$ Here Ibn Sinnā is clear that reaching this stage would preoccupy the human soul fully but not that it becomes one with God. It seems clear here that Ibn Sīnā’s mystical system is not a monist one where the aim is absolute union and becoming one with God, for the reasons mentioned above.

Thus, the immateriality, independence and individuality of the human soul open the possibility of a certain relationship with God. This relationship is demonstrated in the ability of the human soul, through following the ascetic life, worship and spiritual exercises, to advance and ascend to witness and attain conjunction with God's tajalli. This mystical relationship aims at annihilating the body and setting the soul free from all connection with its lower faculties in order to enjoy the observation of the tajalli ultimate light but not to become one with it. Saints who have attained the illumination of the divine light experience the same kind of joy as the divine Intellects in their direct conjunction with God's tajallī. Thus, a human mind which starts as potential and material intellect ends by being similar to the Active Intellect. This is the ultimate happiness which the human soul can enjoy.

\section{Conclusion}

Although Ibn Sīnā was strongly influenced by Greek philosophy, he has many points of criticism of their concepts: he defines God clearly as the only Necessary Existence and analyses the relationship between essence and existence. He does not consider that the human soul is divine in the sense that it has pre-existence and returns to unite itself with its source. He adds to the understanding of the process of knowledge the concept of intuition, which discloses the ability of the human intellect to have conjunction with the Active Intellect and receive divine knowledge. He also analyses the nature of universal knowledge, al-kulli, and explains its immateriality, showing the difficulty of storing this kind of knowledge. Finally, he discerns that the individuality which never fades for each rational being is unique, as shown above. 
Therefore, we may say that Ibn Sīnā was influenced by Greek philosophy in a selective way; he chose what fitted his own philosophy and rejected inimical elements.

Ibn Sinnā however lived in an Islamic culture and environment which no doubt influenced his philosophy; in this he tried through his concept of "the necessary and the contingent" to relate the world directly to God through a divine third element beside matter and form which gives existence to each existent thing. He also insisted on the transcendence of God, of Whom the Qur'ān says, "there is nothing whatever like unto Him" (42:11), in his concept of the only Necessary Existence and the only possible world. Finally, his attempt to relate humanity directly to God through the possible relationship to His tajallī reflects a Sufi conviction that beside God's transcendence there is the other face of His immanence. This, indeed, is his most important contribution to Islamic philosophy, through which a new concept of a mystic philosophy arose. However, in this chapter we found difficulties in tracing the concept of a mystical relationship between God and humanity in Ibn Sinnā's philosophy. The first problem we faced was mainly in his concept of God. The strict unity of the essence of God does not allow Him to actively communicate with the world. Furthermore, the problem of not being the actual creator of the world makes Him lose His omnipotence. Ibn Sinnā tries to surmount this problem in his concept of God's Necessary Existence which makes the existence of the world fully dependent on God in the sense that no possible being can exist except by receiving existence from God.

But the serious problem we faced in the relationship between God and humans in his philosophy is the lack of God's knowledge of the individual. As we saw in the first section of this chapter, the explanation which Marmura gives to this problem does not solve the problem of relating the individual to the knowledge of God. This, as Ghazāli critically pointed out, is the greatest problem in relating humans to God.

The third problem in relating humans to God lies in Ibn Sinnā's categorical concept which designates the position of humans in the world. In the emanation system of Ibn Sīnā, humans are put far down in the scale of beings because of their direct connection with earthly matter which contains change and therefore the possibility of evil. Hence the celestial Souls are more perfect than human souls are, as Corbin shows, although they are also a kind of rational intellect in Ibn Sīnā's philosophy. Thus, humans in his system are the lowest rational thinking beings. But even as rational beings they are not able by the power of their own intellect to reach a conceptual and abstract knowledge of the divine world, as Ibn Sinnā demonstrates in his theory of intuition. The task of the philosopher is mainly to construct knowledge out of the main outline, which he gets from the Active Intellect. Only prophets and scientists in his philosophy can receive knowledge directly from the divine world because they possess a sacred intellect. Hence the human intellect in all its stages is fully dependent on the assistance of the divine world. This kind of inspiration is the only hope, in his view, for reaching a relationship with the Divine. 
Thus, Ibn Sīnā presents here a concept of humans who are dependent on assistance from above and a God who is not able to know humans personally because of the nature of His unity and the manner of His knowledge. The solution for Ibn Sīnā, which allows a relationship between them, depends on two important points: (1) his understanding of divine love, ishq and (2) his concept of the mystical nature of God as being manifested, mutajalli .

In examining the concept of love, 'ishq, in Ibn Sīnā's different works, it became clear for us that the question of divine love is both mystical and philosophical. Divine love is the most important element in God's essence and is the feature which unifies the whole world with God. However, Ibn Sinnā's mystical love is experienced in the encounter of some Sufi saints with divine light which flows in God's tajallī.

The important turning point in his understanding of the relationship between God and humans, however, is revealed in his concept of the beloved One. He presents God as the One who manifests Himself eternally to all beings, presenting Him also as the Light Who breaks through the darkness by calling the world into existence. In this mystical dimension, Ibn Sinnā unveils his own desire to relate God to humanity in its highest form. Therefore, this last image of God for Ibn Sīnā demonstrates his deep belief that God is something to be witnessed rather than to be understood.

Probably, Ibn Sīnā would have developed an absolutely original mystical philosophy aimed at the annihilation of man and union with God, if he had lived longer. As a great philosopher who had his established reputation, Ibn Sīnā was probably unable to develop his mystical thought freely. We can see this in al-Jūzjan̄̄'s advice to Ibn Sīnā not to read his work The Eastern Philosophy (which probably disclosed other doctrines than the peripatetic ones) to his students. The reason is not that his students would not understand it but probably that he should not declare his mystical ideas. Al-Jūzjan̄̄ most probably was aware of the severe criticism of the Baghdādi school of philosophers, led by al-Sijistān̄̄, of the Brethren of Purity for attempting to combine religion and philosophy and considered their works to have a non-philosophical basis, as is reported by al-Tawhīi $\overline{1} .{ }^{191}$

Some 50 years after Ibn Sīnā's death, al-Ghazālī revived this tendency to join philosophy with Sufism and became the pioneer of a new Sufi path which is deeply based on the philosophical understanding of God and human nature. The direction which Ibn Sinnā started, therefore, took on a clear form in the later works of al-Ghazālī. The aim of the next chapter, therefore, is to present a further relationship which demonstrates a great advance in combining philosophy and mysticism and evaluating the highest relationship of annihilation and union between God and Sufi Saints. 


\section{Relationship with God through self-annihilation, fan $\bar{a}$, according to al-Ghazāli}

Fan $\bar{a}$, annihilation, is a mysterious concept which can be studied on many levels. Although it is in the first place an experience which a Sufi is able to obtain at the highest stage of the spiritual life, it is also a philosophical concept which reflects the relationship between the soul and the body and between the soul and the divine world. We noted above that fan $\vec{a}$ ' is connected to Ibn Sīnā's concepts of the independency and separability of the soul from the body. It is also connected to his belief that God has a mystical and mysterious nature which combines His transcendence with His love and eternal light within an unchanging and undivided nature. In the study of fan $\vec{a}$, according to al-Ghazālì', we also need here to examine his concepts of the human and the divine nature which both allow such an experience to happen. However, before pursuing our study of Ghazālì's understanding of those concepts, we should here briefly refer to the problem of evaluating al-Ghazālì's overall system.

In their studies, recent scholars have often noticed great similarities between many elements in al-Ghazālî̀s works and those in Greek thought. Scholars such as A. Badawi, R. Frank and B. Abrahamov connect his output to philosophy rather than to mysticism showing his use of ideas from Ibn Sīnā and Greek philosophy in both his early and his late works. This problem, on the one hand, makes the study of his mystical works more challenging and, on the other, presents a possibility of reconsidering some of his works as authentic, which have been rejected in the past on the basis of their philosophical analysis. Al-Ghazāāi as a theologian and philosopher became very famous through his well-known book Tabäfut al-Falāsifa, which was held to be the final and finest argument against those metaphysical concepts among philosophers which conflict with Islamic beliefs. Although Ibn al-Rushd in both his books Tabäfut al-Tabäfut and Fașl al-Maqāl defended philosophy against most of the charges raised by al-Ghazālī Tabäfut al-Falāsifa remained the book which all theologians used to counter philosophers' claims. However, Tahāfut and Maqāsid al-Falāsifa, according to recent scholarship, are not considered the only books in which al-Ghazālī treats philosophical concepts. Lazarus-Yafeh, in her search for ways of identifying the authentic books of al-Ghazālī , concludes that after Tahäfut he abandoned the use of 
technical philosophical terminology. However, in her book Studies in

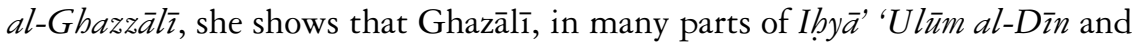
other mystical works, adopts a Platonic cosmology in which he draws connections between the material world and the divine world. She identifies many passages which confirm the Platonic divine ideas and their shadows in the material world, ${ }^{1}$ as will be shown in the section titled "Al-Ghazālī's mystical approach to the relationship with God" of the present chapter. She shows also that al-Ghazālī uses many Neoplatonic images in explaining his mystical ideas, such as the image of the sun and its rays and the emanation of light (fayd al-nür) from God. ${ }^{2}$ Frank in his work Creation and the Cosmic System: Al-Ghazātì and Avicenna also identifies parallel cosmological concepts between Ibn Sīnā and al-Ghazālī. He explains that although Ghazālī rejects the cosmology of the Muslim philosophers in Tahaffut, he explains the workings of God's will in Iljām, his last book, as eternal and necessary. ${ }^{3}$ This means that God's will is closely connected to His eternal knowledge about the world. This approach opens the door to accepting Ibn Sinnā's concept of necessary creation, a concept which is totally rejected in Tahâfut. In addition, Abrahamov, in the article "Ibn Sinnā's Influences on Al-Ghazālī's Nonphilosophical Works" explains that a number of recent scholars have shown connections between Ghazālī’s mystical concepts and those of Greek philosophical thought. Badawi shows that al-Ghazālī's concept of light in Mishkāt has its parallels in Plotinus' Enneads ${ }^{4}$; this is also precisely how Ibn al-Rushd understood it when he read Mishkāt, saying "what al-Ghazālī rejected in Tahäfut he accepted in Mishkät." Van den Bergh discerns relationships between $K$. al-Shukr in Iby $\vec{a}^{\prime}$, and some Stoic sources and Pines show that al-Ghazālī in his ethical discussions in $I h b_{\bar{a}}$ ' borrows parts from Miskawayh's K. Tabdhīb al-Akblāq. ${ }^{6}$

These remarks above raise a question about al-Ghazālī’s system and its final intentions as to whether the way to approach the knowledge of God, as shown in his later works, is mystical or philosophical. Abrahamov shows that in Iljām al-'Awām, Ghazālî̀s last work, he considers that the supreme way to know God is the intellectual but this should not be preached to the masses. He explains that there are six ways to know God graded from the highest to the lowest: "the highest rank is attained through demonstrative proof (burbān) based on certain conditions (shurut), which are well exhausted, and principles $(u s \bar{u} l)$ and premises (muqaddimāt) which are gradually built." However, Iljäm was, in the first place, probably written for the 'Ulamā' of the Nizāamiyya School in Nīshāpūr after al-Ghazālī’s final return to Khurasān and therefore has the intention to identify the highest rational knowledge and to advise that this kind of knowledge should not be discussed with the general masses, al-'awām. In the last chapter of Mishkāt, however, we can see that, although al-Ghazālī regards philosophical knowledge as higher than theological in perceiving the reality about God, he considers that God can be finally known only in the mystical experience of fan $\vec{a}^{\prime}$ when the Sufi realizes that God is the only real existence. At this stage the Sufi sees God through 
the divine eyes. But this chapter of Mishkät also raises a number of problems about whether al-Ghazālī's intentions should be interpreted as philosophical or mystical. This present work will attempt to show that in al-Ghazālîs's late works it is not possible to separate the two ways. Thus, the aim of this chapter is to show that al-Ghazālî’s approach to Sufism was mainly philosophical to the extent that he could be considered the first to have founded a mystical philosophy which subjects all mystical experiences to systematic rational analysis in the light of certain Platonic and Neoplatonic concepts and images.

In examining al-Ghazāli's concept of fana ', first, I want to present here his understanding of the nature of God and of human knowledge. This study will lead us to understand how al-Ghazālī was able to present, in Mishkāt al-Anwār, his most important mystical work and the subject of the section titled "Al-Ghazālī's mystical approach to the relationship with God" of this chapter, his doctrine of fan $\bar{a}$ ' and union, in a sophisticated philosophical image. This chapter has been divided into three sections. The first concentrates on al-Ghazālī's concept of God and contains two sub-sections: one outlining the problem of the divine attributes and showing the development of al-Ghazālî̀'s concept of God and the other examining his belief in God as a willing creator and showing that al-Ghazālī did not doubt this fact.

The second section is concerned with al-Ghazālî̀'s concept of human nature and knowledge. This section is divided into three sub-sections. The first explores his concept of the human intellect, the second examines the various ways of knowledge according to al-Ghazālī and the third examines his conviction that the human soul is composed of a substance which has similarities with God's nature.

The third part of this chapter examines mainly al-Ghazālî̀s mystical approach to the relationship with the divine world. First, I shall discuss the problem of the inconsistency between some of his Sufi works and concepts. Having outlined this problem I turn to his way of approaching the mystical relationship with God, examined under three headings, first exploring his approach to the concept of fan $\bar{a}$ ' in Iby $\bar{a}$ ' 'Ulum al-Dìn, second, demonstrating his mystical teachings to the elite Gnostic mystics on understanding fan $\vec{a}$ and mystical union according to his work Mishkät al-Anwār and, last, attempting to picture the image of God according to Mishkät and to compare it with his concept of God in some of his other works.

After this brief introduction, I first explore al-Ghazālì's concept of God through the different characteristics which he attributes to God and what they signify for his mysticism.

\section{The features of God according to al-Ghazāli}

The features of God according to al-Ghazālī are to be found scattered throughout his works and are difficult to integrate. The main reason is that al-Ghazālī does not demonstrate his view in one or two works; rather, one should read most of his works in order to achieve a fair understanding of his 


\section{God, self-annibilation and al-Ghazālī}

views. In this regard, however, I will attempt to give an account of the features of God by outlining the problems that emerge from al-Ghazālìs different presentations of the divine attributes throughout his different works, and his understanding of God as a willing creator.

\section{The problem of the attributes of God}

In attempting to perceive the features of God as al-Ghazālī perceives them we find ourselves facing the problem that he presents the attributes of God differently in his various works. One difficulty here is that in his work al-Iqtișadd $f \bar{i}$ al-I'tiqād he asserts the Ash'arite concept of God's attributes, though adding other attributes of the essence, while later in Mishkāt al-Anwār he rejects the attributes of God as a source from which His essence may be known. This inconsistency is probably an obstacle in dealing with his works. Are his works, as Lazarus-Yafeh maintains, addressed to different specific readers? Did he change his mind in the course of his writings? Or did his views develop, so that only the later works present his complete position? S. Donia, the editor of Tahäfut, considers that al-Ghazāli presents in some works an official version of his views and in other works his own position and concepts. ${ }^{8}$ Although Frank does not deny that al-Ghazāli wrote some books for popular purposes, he denies that al-Ghazālī writes differently for different kinds of readers but believes that the differences in his writing accord with the different topics in each work; he concentrates mainly on the subject and deals with other views only very briefly. ${ }^{9}$

It is probably true that al-Ghazālī, in general, writes for different kinds of readers. This is easy to verify when reading Tabāfut and al-Iqtișād which were written in the same period but have totally different styles of writing. In Tahâfut, al-Ghazāli uses the language and terminology of the philosophers while in Iqtisad he employs kalām terminology and arguments. It seems, however, that over a period of time al-Ghazālî̀s treatment of the attributes of God passed through many changes during the different stages of his life. Thus, the following section will examine his changing concepts of the attributes of God as found in the chronological order of his works.

Tabāfut and al-Iqtișād fí al-I'tiq $\bar{a} d,{ }^{10}$ which were written soon after one another, present the attributes of God in nearly the same way. Al-Ghazāli adds here ten other attributes, influenced by the philosophical treatment of this problem, to the seven Ash arite attributes. He divides these 17 attributes into 2 parts. One part he calls the attributes of the essence; the other part - the seven Ash arite attributes - the attributes of God.

The attributes of the essence are as follows: the existent, mawjiud, the eternal, qadìm, the everlasting, abad $\bar{\imath}$, the one, wäbid, and the visible, mar' $\bar{\imath}$. The first three attributes affirm certain qualities of the essence of God: first, that It exists and this existence is proved by being the creator of the world, not in the sense of being in itself necessary, as Ibn Sinna maintains, but the fact that its necessity can only be known through the dependency of the world on the 
existence of God. Thus, when we know and prove that the world must have been created, we conclude that $\mathrm{He}$ was the source of all created things. Therefore, He Himself must be eternal in the sense that He was not created or related to time and motion. His eternal existence is also everlasting. ${ }^{11}$

The fourth attribute explains the oneness of God, which has two meanings: the first is His having no partner with Him in eternity and the second is being absolutely indivisibly one, in the sense of being simple and not combined - the kind of oneness, which Ibn Sinna attributes to the first in the last chapter. ${ }^{12}$ The fifth attribute affirms that God can basically be perceived (by sight), but this attribute seems to contradict the next five attributes, which affirm the immateriality of God. Al-Ghazāli admits this contradiction and explains that he does not mean perceiving in the sense of actually seeing, in the way that we see bodies and colours but the kind of seeing which is connected with perception. First of all, he insists that there is nothing in logic against the belief that God can be seen; the intellect denies only the materiality of God because if He is in any way connected with matter, then He must have been created, because matter is divisible and consists of parts. But most probably the importance of this point lies first in its Ash'arite background, and also in al-Ghazālî̀s belief that sight perception is the highest perception because of its connection with certainty. This, he believes, must be the situation of the believer in the last day - that he will be able to have full and certain perception of God. ${ }^{13}$ At the same time, the concept of witnessing God becomes very important in his Sufi works later on, as we will show in the section titled "Al-Ghazālîs's mystical approach to the relationship with God."

The other five attributes of the essence describe in a negative sense the immateriality of God. These attributes are as follows: not existing in a body, not an accident, being not defined, ghayr mutabayyiz, not limited in any of the six directions and finally not seated on the throne. Al-Ghazālī adopts here the philosophical belief that God is better described by negative attributes than positive and he uses this concept to disclose the attributes which must not be predicated of God. The first two confirm the philosophers' image of God that God is neither a substance nor an accident, though all bodies are one or the other and therefore $\mathrm{He}$ is not circumscribed. His existence is also not defined in any direction and $\mathrm{He}$ is not seated on the throne. The importance of these last two attributes for al-Ghazāli is to criticize those concepts which previous theologians had adopted. Theologians who attribute to God qualities which are inspired from some verses in the Qur'ān in their literal meaning, such as the al-Mushabbiha groups and some Ash'arites, believe that God can be defined by being in heaven seated on His throne. Here al-Ghazālī declares God's full immateriality which cannot be in any way defined. However, in his later Sufi writings, he further explains that saying "God is nowhere" means that He is everywhere and He is the only and the whole of existence, as will be shown below. ${ }^{14}$

Al-Ghazāli here gives God, on the one hand, similar attributes to those given by philosophers and, on the other hand, rejects other attributes which some theologians apply to God. However, the main difference here is that 
while Ibn Sinnā believes that God cannot have a genus or differentia, al-Ghazālī affirms both propositions. Genus classifies the common features which many share; for example, the genus "animal" is shared among several beings. In contrast, differentia cover the attributes which differentiate one being from all others. Al-Ghazālì does not deal with this point in Iqtișād but mainly in Tahâfut. He shows in Tahäfut that the philosophers accept God's genus and differentia but only when it comes to describing God's existence; this means that His existence alone can be compared with other beings, not His essence. His main objection to this concept lies in his belief that each essence must have qualities and if the philosophers refuse to acknowledge all the qualities in the essence of God but identify them with His existence, then this would mean that God had no essence or divine qualities, which al-Ghazālī cannot accept. ${ }^{15}$ The importance of accepting genus and differentia is that it gives the grounds for accepting the Qur'ānic attributes of God, which are a basic element in Ash'arite theology.

Although al-Ghazālī defines God in philosophical terms, he also confirms in Iqtișäd seven further attributes which are discussed among the Ash'arite theologians. These attributes are: knowing or omniscience, omnipotence, living, willing, seeing, hearing and speaking. ${ }^{16}$ Beside these attributes, al-Ghazāli even accepts the 99 names of God, but, as we will see below, they were to him mainly examples of what God can be. The reason for this acceptance lies mainly in their Qur'ānic source.

Al-Ghazâlī, indeed, was interested in the question of the attributes from the standpoint of whether God can be knowable or, to put it more accurately, how far God can be knowable. However, he accepts the authority of the Qur'ānic attributes, but shows that they reveal or answer only the question of what God is like but not the question of who God is ${ }^{17}{ }^{7}$ He believes that these attributes and other names which are mentioned in the Qur'ān and the Hadith do indeed demonstrate some of the characteristics of God but do not disclose the whole truth about Him, as we will see later in this section.

In Al-Maqsad al-asna ${ }^{18}$ (The Ninety-Nine Beautiful Names ${ }^{19}$ ) he sets out to explain how we can relate these attributes to God. To understand his theory here we need to examine his concept of the different levels of existence. He explains that there are three levels of existence: the existence of the thing (the being) in reality; its existence in our minds; and finally its existence in the language. If a thing exists in perceptible reality then our mind would have a similar image of it. But verbal explanations of the image, which we have in our minds, are different from the thing in reality. ${ }^{20}$ Thus when we see snow we express it linguistically, using the word snow as a conventional name or we can say it is that which is cold and white. All three words, al-Ghazāli explains, cannot be identified with the image which we have in mind of real snow but only with the meanings which they offer, which evoke a similar picture to the one in our mind.

Here, al-Ghazāli is differentiating words from their meanings. The importance of the word lies only in the meaning it transfers to the mind; thus, 
it is the meanings, not the words, which we look for in giving attributes to God. ${ }^{21}$ The words, therefore, cannot be fully identified with the thing in reality; they are only an expression of it. In this way, al-Ghazālī wants to show the inadequacy of language to give an identical explanation in words to what we see in reality or have in mind. In the case of describing God in language, we realize first of all that we obviously do not have an image of Him in the mind but only an image of who He is through His creation. The second difficulty is the inadequacy of language to express what we have or do not have in mind. ${ }^{22}$

The question here is, when we attribute knowledge to God, do we have an image of what divine knowledge is or can be? Al-Ghazālī answers this question by showing that as everything has three stages of existence the attributes of God also have these stages: eternal knowledge in God, divine knowledge inspired in the human intellect and, at the third level, their existence in the language. ${ }^{23}$ All three levels of knowledge are different from each other; therefore, our knowing of eternal knowledge as it is in God is not possible. ${ }^{24}$ It seems here that, although al-Ghazālī realizes the limitations of human perception and language, he considers that the Qur'ān uses intentionally figurative language which presents God in terms of human attributes only as an example of what God can be like but not who He really is. From this we can see al-Ghazālî's train of thought in Maqsad; although he gives a Sufi understanding of God's different names, he eventually presents a new vision of a mystical philosophy which Ibn Sīnā started, but did not complete.

In Mishkāt, al-Ghazāli $\overline{1}$ comes to his final decision about the attributes, explaining that although God has attributes in eternity, we cannot know the reality of these attributes and therefore we can know Him only by relating Him to His creation. ${ }^{25}$ In Chapter 3 he declares that the Qur'ānic attributes do not reveal who God is and at a certain level of knowledge one should reject giving attributes to God but should rather seek to know Him in relation to the world. ${ }^{26}$ However, the ideal way to know God does not come through the rational study of His attributes but through conjunction with His divine presence, al-badra al-ilähiyya. We will refer to this point again in the sub-section titled "The God of the Sufi saints according to al-Ghazālī" in this chapter.

Therefore, it seems that al-Ghazālī moved away from being a theologian and drew closer to the philosophical understanding of God; yet, adding the mystical dimension here does open the door for the knowability of the essence of God but on another basis. We will see in the section titled "Al-Ghazālîs's mystical approach to the relationship with God" later in this chapter that Ghazāli in Mishkāt believes that the only way to have a certain image of who God is, yaqin , is through a mystical vision, a conclusion which is also shared by Ibn Sīnā in the Sufi part of Remarks and Admonitions.

\section{God: the creator of the world}

The question of the creation of the world occupies an important place in Ghazālî̀s Tabāfut. The importance of the concept for this study is that it 
discloses some features of God. However, this concept went through some modification as well and, although it is an article of faith in Tahäfut, in The Alchemy of Happiness it becomes more mysterious and less important for itself than for its disclosure of the reality of the world. But before examining his theory of the world in The Alchemy we will briefly here explain the importance of the creation ex nibilo concept as set forth in Tahäfut.

There are two main foundations for the creation theory in Tahaffut: the importance of the divine will and the significance of the divine act in creating the world.

\section{God's will in creating the world}

In Tabăfut al-Ghazāli attempts to show the importance of the concept of the creation of the world in disclosing the divine qualities of being willing and active. Al-Ghazāli shows that the philosophers start their argument about the eternity of the world from the First One who has certain qualities and from whom there is a descent to the existence of the world. In this case the world emerges under the conditions and with the qualities which Ibn Sinna and the philosophers attributed to God, using the concepts of "from the one comes only one" and God's incapacity to produce anything, such as matter, which is non-divine. This restricts God's ability of bringing the world into being to that of only emanating the first intellect. ${ }^{27}$

But for al-Ghazāli the world is there and has certain qualities, since the multiplicity of created bodies proves that they must at the end of the chain of causes have a creator, mubdith,$^{28}$ who is the source of all causes. To al-Ghazālin, the world as it exists marks and discloses much of the character of its creator for example, His great knowledge, and His willing to create the world in the form in which it exists - and it shows that it was a voluntary act which brought the world into existence. Therefore, al-Ghazālī asks repeatedly in this section of the Tahäfut what the basis might be for rejecting the view that God has eternal will, and that by an act of will He produced matter or plurality? ${ }^{29}$

The argument about God's will in Tahâfut runs as follows. The philosophers consider that the importance of the divine will lies only in the belief that the world originated at a certain time. They also hold that if God originated the world at a certain time this would posit a change in God from being unwilling to being willing and that this is impossible, for God's knowledge and act are eternal, which to them means that they are unchangeable. ${ }^{30}$

The assumption that God must remain absolutely constant and unchanging means for al-Ghazālī, however, that He is, in fact, not able to act at all, for any act has to have a before, a during and an afterwards. But although we believe that the argument about the eternal will of God was intended, in al-Ghazālìs eyes, mainly to show that God's act must be a willing act, he nevertheless constructs a long argument to prove that the eternal will does not cause a change in God. ${ }^{31}$ To do so, al-Ghazālī relates the will of God to his eternal knowledge: God knew in eternity that He would create the world and decided the time of 
this action. Thus when He actually created it no change in His knowledge took place. The philosophers, however, wonder why God delayed His action? For al-Ghazāli this delay demonstrates that His act is an act of will and there must have been conditions which were to be satisfied in the future. ${ }^{32}$

\section{The significance of God's act in creating the world}

One of the arguments raised by al-Ghazāli against the theory of emanation is its denial of God's willing act in bringing the world into existence. The philosophers, as al-Ghazāli presents them, consider that there are two kinds of act: acts of will and acts of necessity, wäjib. Both kinds of act produce an effect; but when the wished effect is produced, it is not important whether the act of production was willed or necessitated..$^{33}$

In order to show the absurdity of this theory, al-Ghazāli gives the example of a person throwing another into the fire and killing him. We have here two causes: the actual cause is the throwing of the victim into the fire, but in fact death occurs not because of the throwing but because of the heat of the fire. Here, al-Ghazāli maintains, we accuse the person who did the throwing of killing the victim, not the fire. ${ }^{34}$ Therefore an act, for al-Ghazālī, can only mean a willed act.

The second objection, for al-Ghazālī, depends on the nature of the act. An act means bringing something from non-existence to existence, but if the world is eternal then how can we conceive this as an act of God in any sense? ${ }^{35}$ The philosophers assert that the act is attributed to the person after the act is produced and not before, meaning that the product is connected to its producer after it is produced and not in the process of producing it. ${ }^{36}$ In other words, the important point is again that God is responsible for the existence of the world, whether He produced it from nothing or from something which was already in existence. Both of these alternatives make God the producer șanni. ${ }^{37}$

The importance of this highly intellectual discussion in Tabafut is to show the difference between the religious active God whose will changes the history of the world and directs it where He leads it, and the God of the philosophers who generates the world but is not involved in its history. Therefore, for al-Ghazālī anyone who believes in the eternity of the world must end by denying revelation, for revelation is part of God's activity.

\section{The theory of the creation of the world in al-Ghazālì's late works}

In The Alchemy of Happiness, Ghazāli seems to look to the creation of the world from a different angle, which puts this question in a wholly new light and brings it to a different conclusion. He explains that God delegates the creating process to the angels:

To understand God's method of working and governing and the delegation of power to angelic forces he explains, when God wills a thing it appears in the spiritual plane, which in the Qur'ān is called "the 
throne"; from the throne it passes, by the spiritual current, to the lower plane called "the chair," then the shape of it appears on the "Tablet of Destiny" al-lawh al-mabfüz, whence, by the mediation of the forces called "angels," it assumes actuality and appears on the earth in the forms of plants, trees and animals, representing the will and the thought of God. ${ }^{38}$

The passage above declares the existence of two worlds: our material world, which is open to sensible experience and which he therefore calls 'alam al-shäbid or al-mulk, the visible world, and the invisible world of the angels, 'álam al-malakūt. In the Book of Tawhìd in Ibya' he tells us clearly that the angels, though they have this important role, are constrained to follow God's will and instruction. ${ }^{39}$

Al-Ghazālī explains in the above passage how a thing appears on earth. It is not clear whether it is fully created by God alone or through the assistance of the angels, though its product is in accordance with the plan of creation written on the Preserved Tablet. The nature of the divine world with its angels is also not specified as either created or eternal. Zaehner considers that the divine world, according to Ghazālin, is created but at the same time is unchanging and discloses the knowledge of God. ${ }^{40}$ This, however, cannot be inferred from the above text. However, the knowledge which is expressed in the creation process is unveiled from the Preserved Tablet. This term, the Preserved Tablet, appears only once in the Qur'ān (Q. 85:22) and means the place where the Qur'anic text is preserved in the divine world. Al-Ghazāli considers that the Preserved Tablet includes, besides the Qur'ānic text, the secret reality of all the created worlds and the decrees relating to all events. It is the source of eternal knowledge for the two worlds. ${ }^{41}$ The creation of the world seems, in al-Ghazālīs late works, to take place on two levels: the real unchanging world, which is the basic reality of the universe, and the material world, which is created as a copy or shadow of the divine world. ${ }^{42}$

Further, in Misbkāt he shows that the nature of the sun as the source of light and the centre of the world is similar to the nature of the angel who is closest to God; the nature of the moon as the second source of light is also a symbol of another angel - "among the high spiritual existents are those whose similitude is the sun, the moon and the stars." ${ }^{43}$ This idea, as al-Ghazāli hints in Mishkāt, is presented in the Qur'ān in the story of Abraham's search for God. He worshipped first the stars, the moon and the sun and finally recognized the source of all creatures. Some Sufis seem to consider that Abraham worshipped different angels, whom he could associate with the stars, the moon and the sun. Al-Ghazālī probably considers this Qur'ānic story to be the representation of this concept. However, he explains that each element in the material world has another reality in the divine world, in the sense that this world is mainly the material existence of different angels or 
ideas from the Preserved Tablet. Thus, the truth of this world cannot be found here but only reached through its connection with the divine world. ${ }^{44}$ But since the ideas of the Preserved Tablet are eternal it is not clear whether this kind of creation is meant also to be eternal.

This basic cosmological idea is, as Lazarus-Yafeh remarks, very similar to the Platonic divine ideas and their shadow in the material world. Although al-Ghazāli still presents the belief that the divine world is created intentionally in this way in order that the human soul may be guided to reach the knowledge of God, this concept of creation seems to be more mysterious than his argument in Tabafut. The emphasis here is not laid on creation ex nibilo but on the way in which the world was created in imitation of the preserved ideas of the Preserved Tablet. ${ }^{45}$ Again we see that al-Ghazālī has moved away from his theological thinking to a philosophical and mystical concept of the world and its relation to God.

Thus, the question of how God created the world is another area where we can discover al-Ghazālî̀s turning towards a way of establishing the roots of a profound mystical philosophy. We turn here, however, to look at another angle in our study of al-Ghazāli and examine his concept of the human soul and intellect and the possibilities of reaching reliable knowledge of God.

\section{The features of the human soul}

Unquestionably the study of the human soul occupies a key role in al-Ghazālî̀s search to grasp the process of knowledge and in the mystical approach to knowing God. However, this study develops from following Ibn Sinnā's concept of splitting the human soul according to its different faculties to comprehending its esoteric function as being annihilated in the divine presence. He shows in his early work $M \bar{i} z \bar{a}$ n al-'Amal that the soul dominates the body with its intellectual faculty and directs it to act in accordance with the religious laws which lead to moral human conduct. But in his later works he moves from this philosophical understanding of the human soul to a more esoteric perception of it.

Thus, al-Ghazālī studies the human soul differently in different contexts and periods of his work. First, in his work Mìzan al-'Amal he refers to the human intellect in his study of knowledge. In this context he describes the faculties of the soul in the same manner, following Ibn Sinnā's psychology. But he also studies the human soul in the context of his ethical interests in the first three volumes of Ibyya $\bar{a}^{\prime}$ where, following al-Muhāsibi, he provides different steps in the purification of the soul from its sinful behaviour. However, his mystical concept of the human soul, as something which plays a key role in the knowledge of the divine world, is mainly disclosed in his very late work Kimya a' al-Sa'ada (The Alchemy of Happiness). This section of the chapter will mainly concentrate on his study of the soul in the context of his study of knowledge and his mystical approach to it. 


\section{The buman intellect and its functions}

The faculties of the human intellect, as al-Ghazāli explains in Mìzān, are divided into the practical and the theoretical. The theoretical looks into abstract subjects such as knowing God and the divine world. The practical intellect conducts the behaviour of the soul in its relation to the body in order to direct it towards divine knowledge. The faculties of the imagination, kbayal, estimation, wahm, and memory serve the practical intellect. The imagination transfers material things to images, which are then worked out by the estimation and formed into notions and ideas which are partly abstract and partly still related to their sensible origin. These ideas are then saved in the memory. ${ }^{46}$ Under estimation comes, therefore, the knowledge which depends on sensible experience. This according to Ibn Sīnā and Fārābī, is used for exploring ethics, politics and religion. Hence, al-Ghazālī considers the practical intellect to be unable to explore subjects of an abstract nature.

The theoretical intellect, for its part, has three qualities: the first is the potential ability to perceive abstractions, which everyone has to a different degree, the second is the perception of necessary and self-evident knowledge, and the third, its highest quality, is the ability to acquire knowledge about universal abstract notions such as humanity, God and the angels. ${ }^{47}$ The knowledge of God and the divine world comes directly under the theoretical intellect, as al-Ghazālī demonstrates in $M \bar{z} z \bar{a} n$. He presents two different approaches to this knowledge: the first is that divine knowledge will be disclosed from the Preserved Tablet, mirrored to the human mind and united with it. This method acquires knowledge from outside and belongs to what al-Ghazāli calls revealed and inspired knowledge 'ulüm al-mukāshafa. ${ }^{48}$ The second method ensures that knowledge is recalled from inside. Al-Ghazālī explains that God has planted in all hearts before their existence the knowledge of Him and the Qur'ān in many verses speaks of knowing in the sense of remembering. ${ }^{49}$ Here it seems to be that al-Ghazāli is influenced by the Platonic theory of innate knowledge which is obtained through memory of what the soul experienced before its earthly existence.

The rational acquisition of divine knowledge, however, is not available to everybody; there are only a few scholars in whom this knowledge is deeply rooted. The arrival at such a level of knowledge, according to al-Ghazālī, lies in freeing the soul from the five different veils which separate us from the truth. First of all, it depends on the level of our intelligence and maturity: here it seems that different portions of intelligence are decreed to human beings. The second difficulty is being immersed in worldly desires. The third is the lack of interest in contemplating the question of the nature of God and His relation to the world. The fourth veil is the veil of previous beliefs and convictions which have been inherited from parents or teachers. This difficulty prevents us from directing our faces fully towards searching for the truth of God and the divine world. Finally, it is also a problem for many seekers to find the direction from which to explore the truth; in other words, they 
are ignorant of the kinds of sciences and methods which lead to the knowledge of God. ${ }^{50}$ Having stripped away these veils, a soul could start to use one of al-Ghazālî̀s three different methods for obtaining divine knowledge, which will be examined in the next section.

\section{The various ways of knowledge}

Ordinary people, explains al-Ghazālī, are far from the rational path of knowledge, for they are handicapped by most of the veils mentioned on page 130. Nevertheless, they are not expelled from God's mercy; their belief can rest wholly on the assent of the heart to what the prophet and the first caliphs proclaimed. This assent must be on the basis of understanding the main pillars of religion and followed by sincere worship. ${ }^{51} \mathrm{Al}-\mathrm{Ghaza} l \overline{1}$ mentions at the end of Mizzann three ways of knowing God: through following teachers and parents, through following instructions in demonstrative methods, and finally through following what one believes in one's heart through direct disclosure. ${ }^{52}$ Watt identifies these methods with what al-Ghazāli elsewhere terms taqlīd, 'ilm and dhawq. ${ }^{53}$ It may be helpful at this point to examine these three ways of reaching knowledge.

\section{Knowledge through taqlìd}

Frank, in his article "Al-Ghazālī on Taqlīe," explores al-Ghazālī's view of the acquisition of true knowledge. ${ }^{54}$ He explains that knowing, to his mind, falls into three main methods: through the knowledge of others; through the demonstrative proofs which are produced by original thinking or through direct inspiration. Original thinkers, however, are very few; most people follow others, muqallidūn. ${ }^{55}$ Al-Ghazālī, explains Frank, thinks that Taqlìd is a legitimate way of knowing, ${ }^{56}$ contradicting the theory of the Ash'arite School, which required the individual to find his/her own rational convictions. ${ }^{57}$ Al-Ghazālî̀s response to this concept is simply to recall the first Bedouin believers whose assent to the Prophet did not depend on rational demonstration but on a simple assent to what the Prophet proclaimed. As Frank points out, this simple assent probably lies in al-Ghazâlī's belief in the soul's natural knowledge of God which is present in each soul through fitra. ${ }^{58}$ However, this theory of taqlìd seems to be influenced by Ibn Sinā's logical theory of tasawwur and tașdīq. At the beginning of Najāt, Ibn Sīnā explains that Tasawwur means forming concepts on one's own account, whereas tașdī $q$ means granting assent to other concepts. ${ }^{59}$ Also in his theory of intuition, Ibn Sinnā explains that most learned people get their knowledge from those who have the ability to receive a direct connection with the active intellect, as detailed above in Chapter 3.

Taqlīd, however, has many levels, al-Ghazālī maintains, the lowest of which is the simple assent of the believer to the prophet and the first caliphs, 


\section{God, self-annibilation and al-Ghazālī}

al-salaf. Theologians and philosophers are also considered as muqallidūn, explains Frank. For al-Ghazālī there are very few theologians who have original proofs and demonstration methods supporting their knowledge. Most theologians are good followers of their teachers and the line of the school and do not themselves fully apprehend the counter-positions or examine the principles of their school. ${ }^{60}$

\section{Rational knowledge 'ilm}

In his study of the acquisition of rational knowledge, al-Ghazāli mentions the method of knowing through fitra, innate knowledge. In his view, recalling the knowledge which is implanted knowledge in each soul requires following the process of learning, which takes place in the theoretical intellect. It functions through self-evident knowledge and the acquiring faculty. This acquiring faculty, which al-Ghazālī calls al-mufakira, has the ability to acquire a result from two related ideas and a further one from two results. ${ }^{61}$ It follows the logical method of syllogism and for this reason the syllogistic manner of thinking is, for al-Ghazālī, somehow also implanted in the intellect. Al-Ghazālī in al-Qistās al-Mustaqīm goes further by demonstrating that this is also the manner of the argumentation of the Qur'ann. ${ }^{62}$ The highest ability of the intellect, however, is the prophetic faculty, which can possess acquired knowledge without going through the processes of learning. ${ }^{63}$

Al-Ghazālīe unlike Ibn Sīnā but in line with al-Fārābī, believes that the human intellect itself has the ability, when it very carefully follows the demonstrated methods of logic, to get results without outside assistance. But his trust in the human intellect lies probably in his belief that it possesses knowledge through fitra, implanted knowledge. He demonstrates in Mīzān that human beings can possess knowledge by fitra and therefore they only need to transform this knowledge from the potential stage to the active one. ${ }^{64}$ Thus the intellect, for al-Ghazāli , is never at the stage of the material intellect altogether devoid of information, as Ibn Sīnā held. Prophets, for example, seem to possess a strong fitra, which they never forget. ${ }^{65}$ Nevertheless, this rational knowledge is not as clear as inspired knowledge, as we will show in the next section.

\section{'Ulum al-mukāshafa, revealed and inspired knowledge}

Revelation and inspiration are two distinct ways of receiving direct knowledge but are closely connected and run parallel to the rational method of attaining knowledge. However, revealed and inspired knowledge both uncover the Preserved Tablet, which, as explained in the sub-section titled "God: the creator of the world" in this chapter, is the place in the divine world where a full account of the plan of creation and its destiny is to be found. Al-Ghazāli explains: "God wrote a copy of the sciences al-ilm from its beginning to its 
end on a Preserved Tablet and then created the world according to this copy." ${ }^{66}$ In jawähir al-Qur'an he explains that this knowledge is not literally written in words and on a certain tablet, for God's words are without letters and His pen is not made of wood; the whole idea is deeply spiritual. ${ }^{67}$ There are two ways of understanding the idea of the Preserved Tablet: the first is that there exists a certain place in the malaküt where the idea of creation and its destiny are presented in some mysterious manner; the second is that this eternal knowledge flows from God to one of the angels, who in turn communicates this knowledge to the prophets and this is symbolized in the idea of the Preserved Tablet. ${ }^{68}$ He says in one text of $I b y \vec{a}$ ' "the truth of things is written in the Preserved Tablet or rather in the hearts of some angels." 69 However, nowhere can we identify that al-Ghazālī believed in eternal divine ideas in the sense that Plato did; instead, he considers that the malaküt consists mainly of angels who represent certain eternal ideas. Consequently, it is very probable that al-Ghazālī means by the Preserved Tablet one of (or some of) the angels.

The first way of unveiling the Preserved Tablet is through revelation. Al-Ghazāali points out in Iqtișād that prophecy is a free choice and a grace of God offered to whomever He chooses; it is not a result of a natural phenomenon, as Ibn Sīnā would claim. In this point, as Rahman maintains, al-Ghazāli follows the main line of orthodox theologians who believe that prophecy is a supernatural event fully intended by God for a certain purpose. ${ }^{70}$ God is also not obliged to assist the human intellect in obtaining knowledge of the malaküt, as the Mu'tazilites believe, but His gift of prophetic message is pure grace. ${ }^{71} \mathrm{Al}$-Ghazālī's theory of prophecy, however, has some affinity with Ibn Sīnā's in considering prophecy the highest faculty of the theoretical intellect. Prophets of this rank, who are very rare in history, have the ability to receive the most direct knowledge in the clearest form from an angel. Prophets do not go through the process of knowledge as ordinary people do, but are privileged with divine enlightenment. ${ }^{72}$ Revelation, however, is the fruit of prophecy. Al-Ghazāli in Mishkät calls it the light of prophecy which flows from the prophet over the human intellect and illuminates it with the certainty of divine knowledge.

Knowledge of God and of the malaküt, however, is revealed in figurative language on two levels: in abstract ideas and metaphorical passages, which present information parallel to the abstract divine world. ${ }^{73}$ But also some esoteric ideas are expressed in words and verses, such as the secret meaning of light, the divine pen (Q. 68:1, 96:4), the chair, the throne and the Preserved Tablet (Q. 85:22). ${ }^{74} \mathrm{He}$ explains metaphor as follows:

We mean by metaphor or analogue, (mithalal) to render a meaning, (ma'nāa), in an external form, $(s \bar{u} r a)$. So if one seeks its inner meaning, he finds it true. But if he sees only its external form he finds it deceiving... The prophet can talk to people only by means of metaphor, (mithäl), since it is necessary to talk to people in accordance with their intellect. ${ }^{75}$ 


\section{God, self-annibilation and al-Ghazālī}

The metaphors of the Qur'ān, however, can be mainly interpreted through inspired knowledge in the sense of returning the images to their original concepts in the Preserved Tablet. As for the philologists, they are mainly interested in the superficial literal meaning of the words. ${ }^{76}$

The second form of uncovering the Preserved Tablet is inspiration. Lazarus-Yafeh points out a text in Ibya $\bar{a}^{\prime}$ where al-Ghazāli shows that the stage of prophecy is also attainable by some Sufis:

when this (prophecy) is possible for prophets then it is possible for others, for the prophet is a person to whom the realities of things are unveiled and who is involved with improving human morality. Therefore it is not impossible that there exists a person to whom the truth is uncovered but who does not have a mission to lead. We do not call him a prophet (rasül) but a Saint $($ wal $){ }^{77}$

Inspiration differs from revelation in two main ways: in its clarity and in the way it is obtained. Inspiration as experienced among Sufis, as al-Ghazālī explains in $M \bar{\imath} z \bar{a} n$, is a flash of light, which comes and goes, sometimes staying longer than others. ${ }^{78}$ This light reveals parts of the knowledge of the Preserved Tablet. In some of his Sufi works, such as Iby $\bar{a}$, Mishkāt and Jawāhir, al-Ghazālī makes a link between inspiration and revelation through the interpretation of difficult verses or words in the Qur'ān. Since inspiration and revelation have the same source, the Preserved Tablet, they must both cover the same knowledge, but revelation is given as a whole while inspiration uncovers only parts. ${ }^{79}$ Inspiration then is probably able to discover the meaning of difficult revealed parts, such as "everything is perishing except His face" (28:88) or about the angels "We are those ranged in ranks; we are they that give glory" (37:165-6) or esoteric metaphors, such as the chair, the throne, the pen, the Preserved Tablet. ${ }^{80}$ This inspired knowledge is what al-Ghazāli in $I b y \bar{a}$ ' calls 'ulüm al-mukāshafa. ${ }^{81}$ In some of the deeply mystical passages of Iby $\bar{a}$ ' he shows that the meaning of the divine pen in (Q. 96:4) - "He who taught with the pen, taught man which he knew not" - is the angel Jibrill. ${ }^{82}$

Inspiration, like revelation, is communication with an angel, which brings divine information. $I b y \vec{a}$ ' seems to have entailed a development of the concept of angels; in some places al-Ghazālī gives them mainly the Qur'ānic role of communicating revealed messages. But in the last part of I by $\bar{a}$, al-Ghazālī, like Ibn Sīnā, seems to widen their role from that of communicating certain messages to the concept of bringing down all kinds of information about the mystery of the divine world, al-malakut. They seem also to illuminate the human mind by drawing a connection between the divine and the material worlds, revealing that the material one is a shadow of the real world, which is divine. In the Book of Tawhīd in Iby $\bar{a}^{\prime}$ al-Ghazāli explains that God has given His knowledge to the angels in different ranks but directs them to different roles. Though they have the same knowledge as God, they can do only what God wills. ${ }^{83}$ 
In Mìzān and Ihya $\bar{a}$, al-Ghazāli also connects inspiration with the rational approach of the knowledge of God. He explains that the rational knowledge of the 'ulama' (who are deeply rooted in knowledge) is of the same nature as inspired knowledge. ${ }^{84}$ Frank points out the difference between the two approaches as al-Ghazālì sees them: "the mode of presentation (between the two) differs and with it the clarity of the one as compared with the other. Insofar as they bear on one and the same proposition, however, they are equivalent as justified knowledge of a fact." 85 The decisive difference between the two is the removal of the veil, which in the case of inspiration gives certitude. ${ }^{86} \mathrm{Al}$-Ghazāli considers also that rational knowledge is in a sense a preparation for inspiration. In Iby $\vec{a}^{\prime}$ he shows that Sufis should pass through the process of knowledge in order to understand inspired abstract concepts. ${ }^{87}$

To conclude, for al-Ghazāli prophetic revelation is the highest knowledge obtainable about God and the divine world. Inspiration comes second and has the main role of uncovering the esoteric side of messages to humanity. This explains the dynamic conjunction with the truth of the Preserved Tablet which demonstrates dynamic divine guidance. Rational knowledge is in the third place and it prepares the mind to perceive inspired knowledge. Next we examine the mystical nature of the human soul in order to discover its role in the process of fan $\vec{a}$ ' and union with the Divine Presence, as will be explored in the section titled "Al-Ghazālîs's mystical approach to the relationship with God" later in this chapter.

\section{Al-Ghazālī's mystical approach to the human soul}

The Alchemy of Happiness provides al-Ghazālî̀s mystical understanding of the human soul. Although the human soul exists in the material world, it does have another origin. He maintains in this work that the human soul was created in eternity before the body and was sent to earth in order to gain knowledge and experience. He bases his idea on the Qur'ān 7:171:

then the Lord drew forth from the children of Adam from their loins their descendants and made them testify concerning themselves: am I your Lord? They said: yea we do testify; lest ye should say on the day of judgement: of this we were never mindful.

The idea of the celestial origin of the soul derived from this Qur'ānic verse is used by the Sufi school of al-Junayd and is discussed among Sufis such as al-Hallāj and al-Bisțāmī. As explained above, al-Junayd believed that the human soul was an idea in the divine mind before it had an independent existence ${ }^{88} \mathrm{Al}-\mathrm{Ghaza} a \bar{l}$ brings in this verse in order to disclose the relationship between the soul and the heavenly world of the malakut and its natural yearning to return to its origin. ${ }^{89}$ At the same time he refers here to the origin of the fitra, innate knowledge, which discloses that human nature in its purity knows God. 
The body, however, veils the human soul from this knowledge and therefore it needs purification to recall its origin. Al-Ghazālī declares in The Alchemy of Happiness that the purpose of creating the human soul in this material world is to enable it to receive knowledge and experience..$^{0}$ At the same time, he admits that the ability to obtain true knowledge is granted only to some mystics and few scholars, as will be demonstrated below.

Al-Ghazāli attributes different qualities to the human soul; all are very close to the qualities which he attributes to God (see the section titled "The features of God according to al-Ghazālı̄" earlier in the chapter). The following passage shows these similarities:

No one can understand a king but a king; therefore God has made each of us a king in miniature, so to speak, over a kingdom which is an infinitely reduced copy of His own. In the kingdom of man God's "throne" is represented by the soul; the Archangel by the heart, "the chair" by the brain, the "tablet" by the treasure chamber of thought. The soul, itself, unlocated and indivisible, governs the body as God governs the universe. In short each of us is entrusted with a little kingdom, and charged not to be careless in the administration of it. ${ }^{91}$

In this beautiful passage al-Ghazālī says that the role which the soul plays in the body is analogous to the role which God has in the world. Its nature is also invisible, indivisible and unlocated, similar to the nature of the essence of God, as discussed in the sub-section titled "The problem of the attributes of God" earlier in this chapter. This nature is nevertheless created by God and does not emanate from Him, as al-Ghazālī carefully shows in his explanation that God has made us like Him in order for us to be able to perceive His nature. In Mishkāt he explains that this nature is also the nature of the angels and that they are the closest creatures to God..$^{92}$ The main difference between angels and the human soul is that the angels are constrained to obey God while the human soul is impeded from obedience through the desires of the body. ${ }^{93}$ These similarities between God, the angels and the human soul are expressed by the repeated Hadīth: "he who knows himself knows God"94 or the Hadìth "God created Adam in His likeness" 95 in many of his writings. ${ }^{96}$ Such Hadiths seem to have influenced Sufis as well as philosophers, as we saw in the case of Ibn Sīnā in Chapter 3, pp. 102-3.

Another quality of the soul is mentioned in the treatise "On the Meaning of the Intimate Knowledge of God." Al-Ghazāân, like Ibn Sīnā, emphasizes in this the individuality of each human soul. He explains that it is not possible for any two persons to become identical even if they reach the same knowledge and the same level of mysticism. ${ }^{97}$ Each human soul, he believes, is an individual entity which can never be identical to any other entity. We will demonstrate the importance of this point later on, when al-Ghazāli explains the difficulties of union with God, given that no two entities are absolutely the same. 
After providing the above basic knowledge of the nature of God and of the human intellect and soul we turn here to the main task of this chapter, to examine the concept of fan $\bar{a}^{\prime}$ in al-Ghazālì's mystical works.

\section{Al-Ghazālī's mystical approach to the relationship with God}

After the introduction of al-Ghazālī's thoughts on the nature of God and of human beings in the previous sections, we approach the point of considering his mystical approach to the relationship between the two. This section, in the main, will focus on al-Ghazālî̀s concept of fana' through his works Ibyya' 'Ulūm al-Dīn and Mishkāt al-Anwār, because they present details of his mystical concepts. Ibyya presents mainly the basic methods and Mishkāt is intended for those few of the elect, as al-Ghazāli declares in its introduction, who wish to experience the ultimate truth about God. Through reading these two works, however, the reader discovers some contradictions in al-Ghazâlî̀'s concepts, not only between these two works but also between them and his other mystical works. This inconsistency leads to confusion about his actual mystical belief. Is he a sincere follower of orthodox Sufism established by the school of Muhāsibī or did he in his heart adopt the heterodoxy of Hallāj and Bisțāmî̀s mystical annihilation and union? This section of the chapter will attempt to clarify this problem and will start by pointing out some of the main contradictions that give rise to this problem. In the sub-section titled "The concept of $f a n \vec{a}$ ' in $I$ lyy $\vec{a}$ " we will then go on to examine his approach to the concept of $f a n \bar{a}^{\prime}$ in $I b y \bar{a}^{\prime}$ and in the sub-section titled "The concept of fanā' in Mishkāt al-Anwār" its modification in Mishkāt al-Anwār.

In interpreting al-Ghazālì's concept of fan $\bar{a}^{\prime}$ we are confronted with two kinds of Sufism at the same time, one which in its highest stage aims to achieve the love of God and the other which is directed towards annihilation, fan $\bar{a}^{\prime}$ and union with God. Al-Ghazāli considers in $I h y \bar{a}^{\prime}$ that the highest stage of the mystical path is perfect love, which is a longing to see the Beloved, but this vision is granted only in the life to come..$^{98} \mathrm{It}$ is the reward for those who longed to witness God in this life. ${ }^{99}$ This is similar to the kind of Sufism which is presented by Muhāsibīi, who considers that the vision of God is the hope of the mystics in the life to come, the ultimate pleasure of paradise. ${ }^{100} \mathrm{Al}-\mathrm{G}$ azāli $\mathrm{i}$ repeats this concept in the fourth volume of Ibya $\bar{a}^{\prime}$ in a very short section with the title "The vision of God." In this he confirms again that the vision of God is only possible in paradise. ${ }^{101}$

In discussing the unity of God, in the book of Tawhìd in the same fourth volume of $I h y \bar{a}^{\prime}$, however, al-Ghazāan reveals that the witnessing of God discloses the highest form of unity in which the mystic sees only God (and not the world). He divides this concept of tawbid into four levels, the highest of which is a kind of unification with God. This level can only be reached by the 
Sufis: "in this level he (the mystic) does not see any thing in the universe save the One. This is the witnessing of the Sufis." 102 In addition he explains that this vision of God could come as a flash of light or as a permanent state: "this vision in which nothing exists except the existent One and only Truth. Sometimes it remains and at other times it comes as a flash of lightning." 103 At this point al-Ghazālī confesses that this kind of discussion does not belong to the science of mu'amala, the topic of human behaviour but is a secret among the esoteric subjects of "ulum al-mukashafa "this fourth (stage of tawhì $d$ ) should not be further disclosed here." 104

However, in Mishkāt al-Anwār he claims confidently that the Sufi saints, al-'árifizin ${ }^{105}$ will have a vision of God in this life. At the end of the Mishkāt he describes this vision as "the august glories of His face - the First, the Highest - burned up everything perceived by the sight and the insight of the observers." 106 Only through this vision can the Sufi experience the reality of who God is, al-Ghazālī explains. "They have arrived at an existent (thing) that is incomparable with everything that their sight had ever perceived... thus they found Him too holy for and incomparable with all that we described earlier." ${ }^{107}$ He acknowledges a kind of unification between God and the Sufi: "the Sufi saints, having ascended to the heaven of reality, agree that they see nothing in existence save the One." ${ }^{108}$ Al-Ghazāli connects this kind of Gnosticism with al-Bisțāmī, al-Hallāj and al-Junayd, who consider that the highest stage of mysticism is a total unification with God, as will be outlined in the sub-section titled "The concept of fan $\bar{a}$ ' in Mishkāt al-Anwār" later in the chapter.

In order to understand this inconsistency we need to return to the introduction of $I h y \bar{a}^{\prime}$ where al-Ghazāli declares that the first aim of Sufism is to obtain inspired visions of 'ülum al-mukāshafa; however, the preparation for this aim is through the sciences of the conduct of human behaviour called by him 'ulüm al-mu'àmala, which aim to purify the human soul. ${ }^{109}$ Although al-Ghazāl $\overline{1}$ informs us in the introduction that he intends in Iby $\bar{a}^{\prime}$ to present mainly the preparatory stages of the science of human behaviour, 'ulüm al-mu'āmala, ${ }^{110}$ he discloses a great deal of the inspired sciences, 'ulüm al-mukāshafa, which he sees as esoteric and only to be revealed to a few Sufis. In addition, he tells us that the prophets mainly taught the first science of human behaviour and only hinted at the themes of the second. ${ }^{111}$ The reason for concealing the concepts of inspired knowledge, 'ulüm al-mukāshafa, is their abstract nature which is beyond, and sometimes contradicts, the common orthodox beliefs of the ordinary masses, which are mostly based on empirical experience. As Lazarus-Yafeh puts it, "in the Maqsad al-Ghazālī even stated explicitly that truth seems almost like a contradiction of the belief of the masses, a belief to which they have become accustomed and from which they cannot be deterred." 112

Thus, the dual procedure of presenting 'ulūm al-mu'āmala in a direct manner and hinting at 'ulum al-mukāshafa, not only in Ihyy' but in most of al-Ghazālî̀s mystical works, inevitably caused some contradictions between 
his Sufi works. Lazarus-Yafeh observes:

the contradictions between his various books are due partly to the fact that he directed different books to different classes of readers. In books destined for perusal by the initiated (such as al-Maqsad or Mishkāt) he divulged more of the one and only truth, while in books addressed to the masses he had a more reserved manner. ${ }^{113}$

However, this problem of the dual procedure becomes even more difficult when al-Ghazālī addresses the two kinds of reader in one and the same book, as Lazarus-Yafeh points out in connection with his work Ibyja' 'Ulūm al-Dīn. These inconsistencies make for confusion in understanding al-Ghazālî̀s mysticism. We can present here at least two reasons for these inconsistencies in order to shed light on his interpretation of the Sufi system.

The first reason lies in al-Ghazālî̀s belief that there are secrets which should not be revealed to ordinary believers or orthodox Sufis. These secrets, LazarusYafeh says, can be revealed only to the elite who grow in their knowledge to the level of perceiving them. ${ }^{114}$ Al-Ghazālī admits in Ibyya that besides addressing the ordinary believer who wishes to be pious, he gives hints to the elected ones of the secrets of the inspired knowledge 'ulum al-mukāshafa. ${ }^{115}$

The second reason for this duality is probably al-Ghazālî̀s adoption of two different trends in mysticism: the first mainly emphasizes the ethical side of purifying the soul, whereas the second emphasizes the relationship with God through witness, annihilation of all other things in the vision and unification. We observe that al-Ghazālī in Iby $\bar{a}^{\prime}$ gives the name of travelers, al-sălikìn, to the Sufis who follow the first path but from time to time he refers to another kind, whom he calls the Sufi saints. He addresses each section of Ibya Volume 4 to the sälikin ${ }^{116}$ and sometimes he refers to some views of the Sufi knowers al-'arifiñn. In Mishkāt, however, he refers only to the Sufi knowers, al-'ārifin which suggest that Mishkāt represents mainly the second trend of Gnostic mysticism.

He mentions in al-Munqidh min al-daläl that he has read the Sufism of al-Muhāsibī and al-Mikkī which belongs to the first tendency, and also that of al-Bistāmī, al-Hallāj and al-Junayd, who emphasize the second, that of annihilation and union. ${ }^{117}$

Thus, it seems that al-Ghazālî's Sufism is divided into two levels: the first level of the traveller, al-sălikinn, consists, on the one hand, of the purification of the soul from evil habits through worship and meditation, and, on the other, of the ascent of the soul towards isolation from the world, the increase of love and the longing to witness God. The second level of the Sufi knowers al-'árifin is the level of annihilation in the vision of God and unification with Him, which can only be obtained after the above preparatory stages. This level is only available to a few of the Sufi elite; al-Ghazāli hints at this in Ibyya and gives more details in Mishkāt al-Anwār. This kind of mysticism depends fully on receiving inspired knowledge, 'ulūm al-mukāshafa. 
Hence, al-Ghazālī's mysticism seems to form a link between the two trends of al-Muhāsibī and al-Mikkī, on the one hand, and al-Bisțāmīe al-Hallāj and al-Junayd, on the other, by demonstrating that one is a continuation of the other. The first addresses the stages of the purification of the soul and its ascent to a certain level, and the second emphasizes the ultimate relationship of vision and unification with God, which only a few can reach, as will be shown in the following sub-sections.

\section{The concept of fanā' in Ihya $\bar{a}$}

Al-Ghazālī in $I$ by $\bar{a}$ ' presents a kind of mysticism which in its main concern aims at purifying the soul by following different stages through which the Sufi will ascend to the stage of love and the longing to see the Beloved. Al-Ghazālī considers that there are stages which are desired for their own sake and others which are stages leading to the ultimate aim. Love and fellowship with the divine presence are the highest stages, the ultimate aim of the path of mysticism. ${ }^{118}$ All other stages, maqāmāt, are preparatory stations for gaining the ultimate love of God.

The method which al-Ghazālī uses here for ascending these preliminary stages is to recognize in each stage three dimensions: knowledge, feeling and action. Knowledge, al-Ghazālī explains, examines the deep and genuine meaning of each stage, which produces a certain feeling in the heart. This feeling in turn initiates an action, which helps the seeker to climb to the next stage. This act assists the soul to withdraw from its love for this world. He follows this method in exploring each of the preparatory stages.

A. Schimmel explains that the mystical path consists of maqāmāt, stages, and aḅāl, states:

A state is something that descends from God into a man's heart without his being able to repel it when it comes, or to attract it when it goes... the maqām is a lasting stage which man reaches, to a certain extent, by his own striving. It belongs to the category of acts, whereas the states are gifts of grace. ${ }^{119}$

Al-Ghazālī follows this concept that mysticism depends to a great extent on God's choice, but the chosen one has to make an effort in order to reach the highest stages. We notice that al-Ghazālī in his explanation of the difference distinguishes between ordinary seekers who wish to limit their path to the law al-shari' $a$ and the others who direct their face towards God Himself. The latter group are again divided into beginners, whom he calls al-sālikinn, and those who climb to the highest stage of self-annihilation and union. This second group, consisting of Sufi saints, al-Ghazālī calls al-'ärifīn, those who wish only to devote their life to observing the divine beauty, as will be discussed. We observe that al-Ghazālī addresses mainly al-sālikīn at the 
beginning of each stage ${ }^{120}$ but points out that the highest rank is that of the Sufi saints.

Schimmel notes that the mystics identify three parts of the religious life: the law, sharī' $a$, the path, țariqa, and Gnosis, haqüqa and ma'rifa. The sharī'a is expressed as "what's yours is yours and what's mine is mine"; tarīqa is "yours is yours and mine is yours too" and baqiqa is "neither mine nor yours but all is God's." Thus Sufi saints see everything in unity with God and move towards self-annihilation and union in which they end their own individuality in their observation of the divine beauty. ${ }^{121}$ In this way, al-Ghazāli explains the levels of the tarīqa but aims at the haquiqa by hinting at it in Ibyy and unveiling it in Mishkät.

Although al-Ghazāli in $I b y \vec{a}$ does not aim to deal with the concept of fan $\vec{a}$ and union, Ittib $\bar{a} d$, he gives a good explanation of fan $\bar{a}$ ' in examining the stage of trust tawakkul. This stage is composed of three levels: in the first level the Sufis delegate all authority to God and let Him be their deputy and represent them in all things. The second level is to depend on God as a child fully trusts and relies on his mother. The third and highest stage of trust is to submit oneself fully to the will of God as the dead body submits to those who wash it before the funeral. Al-Ghazālī admits that both the second and the third levels are very rare, because human choice will be very limited in the second and wholly absent from the third level. This is the level of the Sufis and the saints. ${ }^{122}$ This kind of mysticism, therefore, is based on the denial of the self and its interests, on the one hand, and on a profound belief in the absolute divine decree, on the other. This is an elementary level of experiencing fana ${ }^{\prime}$. At this stage the seekers reach the full trust of believing that by the power of God they could walk on water or fly in the air. This trust is built on the metaphysical concept of tawhìd, the unity of God with the world. Al-Ghazāli sees four levels of this concept: in the first are those who believe only literally that there are no other gods save God; the second level contains those who give assent to this belief with their hearts and the third level, those who see that everything is God's product and creation. The highest of all is the level of the Sufi saints, al-'arifìn, who believe that nothing actually exists except the One. They call this level the annihilation of the self in unity. ${ }^{123}$

Al-Ghazāli admits that those stages should not be explained in $I b y \bar{a}^{\prime}$ for they belong to the revealed sciences of 'ulüm al-mukāshafa. ${ }^{24}$ Hence, al-Ghazālī makes it clear at this point that there is a certain level of mysticism which he does not wish to discuss publicly but only to hint at. He declares that love and the longing to see the Beloved is the highest stage that he addresses in I $b y \bar{a}^{\prime}$. Only at this stage can we deal with revealed and inspired knowledge, 'ulüm al-mukäshafa. Thus, he repeats here several times that it is not possible to reveal this knowledge but rather "in this place we have to bring our writing to a close." 125

At this highest stage of love the soul experiences a longing to return to its origin. Al-Ghazālī here collects the following Qur'ānic verses and Hadìths, 
which all point to this mysterious relationship: "I breathed into man of $\mathrm{My}$ spirit" (15:29), (38:71-2) "if they ask you about the soul, say the soul is from God" (17:87), "I am setting in the earth a vicegerent" (2:30) and others. There are also different Hadīths such as "God has created Adam in His likeness" or the one that says that when God loves a person then He becomes "the hearing by which he hears, the seeing by which he sees, and the tongue by which he speaks" or "he who knows himself knows God."126 We will see that he uses these Ahādīths and the Qur'ānic verses in Mishkāt to express a certain unity between God and the Sufi.

However, at this stage al-Ghazālī discloses a different level of defining God. He is not a lover who has emotions and feelings but is above all human descriptions and similitudes. His love towards humans is utterly different from theirs. Since love as analysed above is an attraction towards perfection, al-Ghazālī considers it inapplicable to God, "This however is impossible for God because all perfection and love and beauty is present in Him." ${ }^{127} \mathrm{He}$ is probably influenced here by the idea of love which Ibn Sīnā introduced in The Treatise on Love (see Chapter 3).

But al-Ghazālī goes beyond Ibn Sīnā, who shows that God's love is mainly towards Himself, to make it clear that God, as pure perfection in Himself, loves His perfection and the autonomous actions of this perfection which means that He loves the world as His own action and a part of His existence; "He loves the all in Himself because $\mathrm{He}$ is the all." ${ }^{28}$ God's love, for al-Ghazālī, is mainly shown in the perfection and beauty of His creation, in the love of goodness which human beings have by their nature, and finally by the way in which He draws good mystics near and unveils Himself to them. ${ }^{129}$

Thus, as noted in the discussion above, the dualism of $I b y \bar{a}{ }^{\prime}$ is due to the wish of al-Ghazāli to address Ibyya to the ordinary pious as well as directing the elite, through short or detailed hints, towards the Sufism which aims at annihilation and union. Lazarus-Yafeh observes:

while perusing the book (Ibya $\left.\vec{a}^{\prime}\right)$ the reader would get the impression that a section had been penned by two different authors simultaneously; or that the author had addressed the average reader in a loud and confident voice, while in the meantime whispering additional hints to that reader who belonged to the chosen few. ${ }^{130}$

Al-Ghazālī, however, addresses to the reader who is keen to involve himself in the search for divine eternal knowledge some other works about the reality of the divine world, the inspiration of the Sufis. Thus, we turn here to examine his view of the deepest knowledge of God, in his Mishkāt al-Anwār.

\section{The concept of fanā' in Mishkāt al-Anwār}

Al-Ghazālī declares at the beginning of Mishkāt that he will deal in this book with some of the inspired subjects in response to a friend who asked for an 
interpretation of the verses of the Qur'ān which describe light. He begins his reply:

I see you as one whose breast has been opened up by God through light and whose innermost consciousness has been kept free of the darkness of delusion. Hence in this discipline I will not be niggardly towards you in alluding to sparks and flashes or giving symbols of realities and subtleties, for the fear of holding back knowledge from those worthy of it is not less than that of disseminating it to those not worthy of it. ${ }^{131}$

Here al-Ghazāli shows that he will disclose some of the secrets of 'ulüm al-mukāshafa. These secrets probably demonstrate the kind of mysticism which he follows, because at the end of Mizian al-'Amal he says that every person has three sorts of belief: what he has learned from his parents, what he has learned through acquiring it and what he really believes in his innermost heart and can only disclose to others who share his belief. ${ }^{132}$ In the introduction of Mishkāt, we notice that al-Ghazālī's intention is to reveal some of the visions concerning the subject of God as the highest light and the different kinds of veil which obscure this vision. His aim in this discussion is mainly to demonstrate, on the one hand, the reality and the different dimensions of the concept of annihilation and union (Chapter 1) and, on the other, to reveal the real image of God through personal vision and the veils which conceal this vision (Chapter 3).

In Ibya 'al-Ghazāli declares that the actual vision of God is mostly to be obtained in the next life. Here al-Ghazālī presents a type of mysticism which is fully dependent on this vision. His mysticism here is very closely related to his theory of knowledge and to the knowledge of cosmology. Thus, in this level of mysticism here he no doubt has in mind the elite Sufis who have acquired knowledge before or during their mysticism. ${ }^{133}$ His concept of fan $\vec{a}$, as is unveiled in Mishkāt, is closely related to his theory of the metaphysics of light and the different veils which obscure our vision of it. Thus, in order to reach the experience of $f a n \vec{a}$ ' we should first examine the concept of light explained in his first chapter.

In this chapter al-Ghazāli meditates on the motif of light through which he attempts to elucidate and evaluate the mystical experience of God. He distinguishes two main kinds of light: the sensible light which shines on things and causes their appearance to the eye and spiritual light, which reveals the reality of things and the unseen world. In parallel to these two lights exist two kinds of eye, the outward and the inward. The outward eye receives the first kind of light and the second is perceived and apprehended by the inward one or the intellect. Light is attributed to both the intellect and the eye, for they transfer the reality of the world to the human soul. In its perception of divine knowledge the intellect depends on necessary knowledge and the learning of wisdom. The highest wisdom for al-Ghazālī, however, is the speech of God in the Qur'ān. The Qur'ān, therefore, is the light which links 
the human intellect - at its highest level, the prophetic intellect - with the light of the divine world. ${ }^{134}$ Light is attributed to angels also, according to al-Ghazālī, because they have the role of illuminating the human intellect with revealed knowledge from the Preserved Tablet. ${ }^{135}$ Al-Ghazālī here builds a hierarchy of light ascending from the light of the prophetic intellect to the different ranks of the light of the angels, and further, to reach the source of all lights, God the One.

However, the way in which al-Ghazālī sets out the relations between the different lights in this hierarchy has caused uncertainty among scholars. He explains:

the low lights flow forth, fä'id (fayd), from one another just as light flows from a lamp. The lamp is the holy prophetic spirit. The holy prophetic spirits are kindled from muqtabas (iqtibass), the higher spirits, just as the lamp is kindled from the light. Some of the high things kindle each other, and their hierarchy is a hierarchy of stations (ranks). Then all of them climb to the Light of lights, their origin, their first Source... all other lights are borrowed musta'âra (isti'ära). The only true light is His. ${ }^{136}$

In this passage he uses three words, all conveying Neoplatonic images, which are used by philosophers. These words are ista'āra, borrowing, iqtibass, taking over from, and fayd, emanate. Al-Ghazālī uses these words to explain the relationship of the different lights to one another and of all of them to God, describing them in a manner which could be interpreted as emanation.

Gairdner in his article "Ghazālī's Mishkāt al-Anwār and the Ghazālī problem" explains that Ibn al-Rushd considered that al-Ghazālī accepted as the theory of emanation in Mishkāt some of the concepts which he rejected in Tahāfut. Gairdner seeks to explains this saying that al-Ghazālī uses a form of fäda: fäda min... 'ala, which could have a different meaning from "emanation."137 But Lazarus-Yafeh interprets al-Ghazālīs use of the word fäda and other Neoplatonic words, which mean flowing over or emanating, with a moral or literary rather than a metaphysical meaning. ${ }^{138}$ Since light in this context is a symbol of knowledge, then the flowing over of light means here the pouring out of knowledge from God to the angels and the human race. This kind of emanation does not refer to the way in which the world originated from God but rather shows how humans reach eternal knowledge. ${ }^{139}$ Lazarus-Yafeh counts the many passages from $I b y \vec{a}^{\prime}$ and other works which use direct Neoplatonic words or images and maintains that al-Ghazālī uses them mainly to express Neoplatonic ideas which do not contradict the tenets of Islam. ${ }^{140}$ Nevertheless, al-Ghazālī mentions them in the context of the Hadīth: "God has created the world in darkness and then He poured upon them some of His light." ${ }^{141}$ He deliberately chooses here a pseudo-Hadīth in order to present an image of emanation which shows that real existence became possible when God poured His light upon the world, and this clearly relates emanation to the existence of the world. 
At all events he explains here that as knowledge has its source in the eternal knowledge of God, existence too is borrowed in full from the necessary eternal existence of God. There are two kinds of existence, he continues: borrowed existence and self-existence. The world is divided, therefore, into God as the only self-existent and the universe as the reflection of His existence. The only real existence, consequently, is the existence of God, which reiterates the idea that the existence of the universe is poured out of or emanates from God, the only possessor of existence. ${ }^{142}$

This metaphorical existence is proved to the Sufi in his experience of annihilation. When the Sufi saints, at the end of their stages of ascent, experience God as the only existent One, they experience the reality of the temporal world as non-existent in itself. In their ascent they move from the material multiplicity to the universal truth, through which they loose their ties with the material world. At this stage they experience the verse "every thing is perishing except God's face" $(28: 88),{ }^{143}$ which al-Ghazālī here explicates to show that all things have no independent existence, for the basis of their existence is only borrowed. This again shows here that al-Ghazāli is moving away from the concept of creation ex nibilo for creation means something concretely appearing from nothing, which is difficult to reconcile with its being only a shadow and an illusionary existence.

When the Sufi, however, experiences this truth and sees only God, which means that his own existence is melted in God, he becomes totally amazed and therefore only aware of God's existence. Al-Ghazālī had hinted in Ibyya', as we showed above, that God's unity does not simply mean that there are no other gods but that He is the only real Existent, al-mawjüd al-baqiq $\bar{\imath}^{144}$ This experience is metaphorically called union, al-Ghazālī maintains, but in reality it is the experience of God's unity as the One and the only real Existent. ${ }^{145}$ However, these facts may be perceived either through an intellectual Gnosticism, 'irfän 'ilmī, or tasted in a mystical experience. ${ }^{146}$ Of those who have tasted it, their "plurality is totally banished from them and they became immersed in sheer singularity. Their rational faculty becomes so satiated that in this state they are, as it were, stunned." 147 Some of them become intoxicated and cannot think of themselves as distinct from God, al-Ghazāli reports, so they say, "I am the Real" or "Glory be to me, how great is my station." However al-Ghazāli interprets these statements with the following words:

the speech of the lover in this stage of intoxication should be concealed and not spelled out. When this intoxication subsides, the ruling authority of the rational faculty - which is God's balance on earth - is given back to the mystic. They come to know that what they experienced was not the reality of unification but that it was similar to unification. ${ }^{148}$

Thus, the question which presents itself here is: how could al-Ghazālī reject the experience of union, when he showed in some parts of $I b y \vec{a}$ and in 
Misbkāt that the highest mysticism is that of the Sufi saints such as al-Bistāāī and al-Hallāj, whose aim is annihilation and union?

In many of his writings al-Ghazālī rejects the concept of union because of the impossibility of two entities becoming one unless they are totally equal, in which case one of the two must lose its existence and become a third one. ${ }^{149}$ This, however, is impossible in the case of union between humans and God because although they have similarities, nothing is equal to God (Q. 112:4). Therefore, for him the difficulty of this union lies in its technical impossibility. Here al-Ghazālī probably refers to al-Bisțāmī’s idea of the total identification with the divine essence, as was outlined in Chapter 1.

In commenting on the experiences of al-Bistāmin and al-Hallāj, he first of all shows the difficulties which are connected with them by referring to some kinds of visual illusion which everybody experiences: when we see a bottle of wine, we suppose that the bottle has the colour of the wine because the two are unified. The light of the sun, too, is unified with things when we recognize only the things and not the light. But when the sun sets, we realize the function of the light. This illusion of the unification of two things can be observed as long as we can perceive their opposite:

when the sun sets, when the lamps are put away and when the shadow falls, the deniers perceive a self-evident distinction between the locus of the shadow and the place of brightness. Hence they confess that light is a meaning beyond colour and is perceived along with colour. ${ }^{150}$

But in the case of Sufi saints, when they see God, the light of their hearts becomes unified with the divine light; they see everything through the divine light. This light, says al-Ghazālī, never sets as the sun does, and therefore it is difficult to realize oneself in this experience except when the vision comes to an end. ${ }^{151}$ In the above examples al-Ghazālī does not deny the integration of the bottle and the wine or the light and the things seen by it. This integration, however, does not imply that the two have become one; he says that they remain two although we are aware only of one.

Thus, al-Ghazālī here gives two explanations of this experience: the first is that when the Sufis depart from the material world and enter the divine world, they see the truth that this material world is only illusion and the truth is that God is the only real existent. This is a philosophical fact which can only be experienced and perceived when the Sufi reaches the divine knowledge and sees the world through God's eyes. The second explanation is that there is a kind of unification between the souls of the Sufis and God. By the sentence "it was not ittị̧a $\bar{d}$ but similar to ittiḅa $\bar{d}$ ", al-Ghazālī wants to distinguish between identification and (similar to ittib̧a $\bar{d}$ ). Ittib̧a $\bar{d}$ refers to two things absolutely becoming one but integration seems to be, from the examples above, one thing's circumscribing or embracing another thing so that the one can be seen through the other. In this case one of the things can be greater than the other which it circumscribes. Here we may recall al-Ghazālī's concept of the essence of God mentioned above. Al-Ghazālī 
explains elsewhere that God's immaterial essence exists everywhere and is not restricted in any direction. He also says in Iljäm that the presence of God is like a kingdom in which the throne is the closest location to the king and the outside square is the furthest, but all exist within the royal kingdom. ${ }^{152}$ Thus, it seems that malaküt for al-Ghazālī means mainly the divine presence, which embraces all things (probably also the whole universe). This means that the human does not become a God but that he/she disappears in the Divine.

Thus, when the souls of the Sufis, which are isolated from the body through annihilation, leave the material world and enter the malakut, they enter into the divine presence. In this case, it is not possible to distinguish the boundary of the individual self, which has perished, in the divine presence.

It seems that al-Ghazālī wishes to present here a different dimension of the idea of "union" and explains that it does not simply mean that two become one but that the two remain two, because in fact only the real One ever really existed. Thus, he interprets this experience as being beyond the limitation of the intellect, but in a philosophical manner. Al-Ghazālī accepts the Sufi experience of al-Hallāj and al-Bistāmīi but does not interpret it as a human becoming a god. Thus, humans are not in his view unified with God's essence but mainly with God's knowledge or presence. Therefore, although al-Ghazāli considers the experience of union a secret, which is known only to those who have experienced it, he endeavours to understand but cannot intellectually accept a full identification with God.

The highest stage of mystical experience for al-Ghazālī, therefore, is the soul's annihilation in the divine presence and integration in the divine eternal knowledge, which, as he mentioned earlier, flows from God and is one with the angels and the prophetic intellect. It results in the Sufi saints' observing the world through the divine eyes: "one of them might add to this and say 'I never see a thing without seeing God before it'. This is because this one can see all things through God." 153

After exploring the main features of al-Ghazālì's mysticism, we conclude this section by discussing the characteristics of God as they are known to the highest rank of the mystics.

\section{The God of the Sufi saints according to al-Ghazāli}

In the first chapter of the Mishkāt, al-Ghazāli contemplates God as the source of light which leads to gnosis, ma'rifa; this light is cast into the heart of the mystics and gives them their knowledge of God and the divine world as they really are. Through complete self-denial the Sufi saints reach a union with the divine light and obtain a vision and a perception of who God really is. In the third chapter ${ }^{154}$ of the Mishkāt, al-Ghazālī resumes his discussion from the first chapter of the essential characteristics of God. He intends in this chapter to comment on the Hadīth "God has seventy veils of light and darkness, were He to lift them the august glory of His face would burn up every one whose eyesight perceived Him." 
Al-Ghazālī asserts at the beginning of this chapter that God in Himself is always manifested to all beings but humans veil themselves through darkness, light mixed with darkness or a veil of light. Lifting up these three kinds of veil in order to see God comes through the ascent from the sensible world to the divine world of light. The first veil consists of being immersed in all material desires without reference to an after-life or to a divine world. The second veil is the first stage of ascending from the sensible to the spiritual and abstract. All the groups under this veil have the desire to know and worship God; but some acquire this knowledge through the faculties of the imagination in which they draw an analogy between God and what they sensibly experience. Others infer knowledge about God through the faculty of estimation, wabm. ${ }^{155} \mathrm{Wahm}$ is the highest faculty of the practical intellect which draws abstract ideas from sensible experience, for instance, the idea of enmity, which is experienced in moments of perceptible danger. Therefore, the members of this group, probably the theologians, know God through drawing analogies with the human qualities of knowledge, ability, generosity and the like. They are not able to perceive any abstract, al-Ghazālī explains, which goes beyond some analogy with what they know. ${ }^{156}$

The third veil is a veil of light, which probably means the closest knowledge to the saint's vision of God. Al-Ghazālī presents here the different metaphysical theories among the Arab philosophers of his time who had the ability to see God through the abstract thinking of the theoretical intellect. Some connect Him with the movement of the world and others consider Him moving only the outermost sphere but a third group raise Him above direct contact with the cosmic system to the role of the One who commands it. They identify Him with al-Muta $\bar{a}^{6}{ }^{157}$ This role of creating through commanding the cosmic system, as Zaehner points out, is the role which God takes in the Qur'an. He commands the creation through His uttering of the word "Kun" (Be) (Q. 3:59). ${ }^{158}$ The theory of al-Mutā' probably comes from the Isma'īli who consider $a l-M u t \bar{a}^{-}$in the role of the Universal Intellect of Plotinus. Zaehner explains that $a l-M u t \bar{a}^{-}$is a Qur'ānic character who appears only once in the Qur'anic verses (81:19-21) "It is verily the speech of a noble messenger, powerful beside Him of the throne established, obeyed $\left(M u t \bar{a}^{\circ}\right)$ there and trustworthy." Some commentators consider here that the Muta $\bar{a}^{6}$ is Jibrīl, though Zaehner considers him to be Muhammed, the "transcendent prophetic spirit." However the Ismā'̄il̄ $\overline{1}$ consider that the $M u t \bar{a}^{r}$ represents God in that he commands the creation of the world through the commanding word "Kun." 159

But why does al-Ghazālī consider that the Ismā‘n̄līs worship al-Mută as God? Probably, he is hinting here that in the Ismā'îlī system God does not have any role except that of one from Whom the $M u t \bar{a}^{\prime}$ emanates, similar to the Neoplatonic One, and that the divine role is given to the Muta $\bar{a}^{\prime}$ alone. Here he points out that the Sufis distinguish between the role of God and that of the highest Archangel, whom they call al-Mutā'. ${ }^{160}$ However, al-Ghazāli considers that these groups of thinkers, though they present God in a highly abstract form, are veiled from His ultimate truth. Thus, 
al-Ghazālī here rejects the Aristotelian Prime Mover and the emanated $a l-M u t \bar{a}^{\prime}$ of the Ismā'i 1 is and identifies God with the one who is beyond any connection to the world. God is not the one who gives the command but is superior. Is He then the God of Ibn Sīnā whose tajallī is the absolute reality and who stands beyond all connections but through whom everything receives existence and love? Or does he mean here that God is the one who is responsible for all existence without the use of commands such as humankind uses but in a mysterious, wholly immaterial manner? However, although al-Ghazālî's description of God is similar to that of the Neoplatonic philosophers, especially Ibn Sinnā, he decides at the end of Mishkāt that only the Sufi saints possess real knowledge of who God is.

Now, however, he explains that human beings veil themselves in their wish to know God through the different faculties of the intellect. The problem lies, in his opinion, rather in the immateriality of God, which cannot be defined by moving in any known direction: "because something that is not related to directions and is not described as outside or inside the world is not, in their view, an existing thing." ${ }^{161}$ Even the philosophers who can perceive such a being confuse His role with that of the angels.

At this point al-Ghazālī starts to present God as a Being who is "neither inside the world nor outside." ${ }^{162}$ This Being cannot be perceived by the faculties of the soul mentioned the section titled "The features of the human soul," but only by the prophetic holy intellect. This faculty, he explains in Chapter 2 of the Misbkat ${ }^{163}$ is beyond rational perception and is the only faculty capable of perceiving the secrets behind the material world. ${ }^{164}$ Thus, for al-Ghazālī, the reality about God can only be disclosed through the prophetic experience of the vision of God. As he explains in I $I b y \vec{a}$, the vision of God is a vision of the heart and not the sight; here in addition he illustrates that this vision is only through the highest faculty of the heart, which is not available to ordinary people. This faculty is, however, not restricted to prophets alone; he encourages the Sufis to "strive to become one of those people who taste something of that spirit (prophetic spirit), for the Sufis (saints) al-awliy $\vec{a}$ have an ample portion of it." 165

It seems here that al-Ghazālī does not aim to describe God in an esoteric manner, showing the unknowability of the Divine, but rather to state that the sensible, imaginative and rational faculties are not able to know reality, whether about God or about the divine world, the same conclusion that he reaches in Tahāfut. Thus, in Mishkāt, God's features, to al-Ghazālī's mind, do not differ from those in the al-Iqtișad f $\overline{\bar{z}}$ al-I'tiqa $\bar{a}$, or in the Book of Love of Iby $\bar{a}$.

The main emphasis in all these texts on al-Iqtișäd, Ibya and Mishkāt lies in the concept of the otherness of God. His love is different from ours because His qualities are perfect, while ours are longing for perfection. He is not in need of gratitude or worship but all his commandments are made so that humans can enjoy the truth about God through avoiding its opposite in this life.

This truth, however, is experienced only through the prophetic souls of prophets and Sufi saints and is delivered to the pious. We have shown above 
that these descriptions have affinities with the Neoplatonic God, as formulated by Ibn Sīnā. For him, God plays mainly the moral role of being always manifested, mutajalli , attracting the whole world through love and knowledge and giving each thing existence. ${ }^{166}$

However, al-Ghazāli demonstrates that God does more than attract the universe to His light; He is active in all events and in the acts of all beings. $\mathrm{He}$ is aware of the world in loving the whole of it in Himself as His own act, in drawing the Sufi saints to have full unification with His will and knowledge, and in His eternal divine plan to create the world in the way that it exists and to control it through His divine decrees.

To conclude, al-Ghazālì's understanding of the relationship between God and mankind is influenced by some Neoplatonic concepts, the Sufi experiences of such different Sufis as al-Hallāj, al-Bisțāmī and al-Junayd, and many esoteric Qur'ānic verses and Ahāāìth.

\section{Conclusion}

Al-Ghazālī’s Sufi writings form an original system which is heavily influenced by prophetic revelation, philosophical knowledge and mystical knowledge and experience. Already in Tahäfut he had declared that philosophical principles are not able to explain the whole truth about God and he shows that many of these principles are only prior assumptions which the philosophers cannot prove. Thus he shows that certainty requires revelation. Yet his discussion in Tabäfut and in al-Iqtișād shows the importance of learning philosophy in order to perceive the main features of God. In al-Iqtișād he explains the unity of God in a way very similar to the Neoplatonic description of the essence of God. Later in the Mishkāt he asserts the knowledge of God through His acts rather than His attributes because God as He is can only be witnessed through His acts.

It seems, then, that even after al-Ghazālī rejected philosophy in Tahâfut he assimilated into his system some philosophical ideas and concepts. He also transformed philosophical terms, for example, Universal Intellect, the Universal Soul and the like, using other esoteric Qur'ānic words such as Preserved Tablet, al-lawh al-mahfüz, or the divine pen or the throne. ${ }^{167}$

The main structure of his Sufi thought is that deep knowledge needs a purified soul, which on the one hand prepares it morally to approach closer to God and on the other directs the intellect to the highest divine knowledge. $I h y \vec{a}^{\prime}$ is the reference book for this purification. Moral purification depends mainly on a profound understanding of worship and religious habits. The scattered esoteric ideas and concepts of God and the divine world in Ibya form another kind of preparation for the elite Sufis who do not only wish to be near God but desire a vision of Him. Mishkāt al-Anwār is the work where al-Ghazālī leads the elite to recognize the importance of the vision of God as the only possible way to know the essence of God and who God really is. He also explains the idea of union and shows all its dimensions. 
The main features of al-Ghazālī's mysticism, however, are his use of philosophy, his thorough philosophical analysis of Sufi knowledge and experience and his use of metaphorical Qur'ānic material. Al-Ghazālī explains in Jawāhir al-Qur'ān that the Qur'ān has a direct message to the ordinary believer but also contains quantities of metaphors and esoteric ideas. These secrets are given only for the elite who are able and willing to have intimate knowledge of God and the divine world. The depth of these secrets has, on the one hand, affinity to some philosophical concepts such as the Neoplatonic concepts of necessary existence and knowledge, as shown above. ${ }^{168}$ On the other hand, it is also in accordance with the experience of many Sufi saints, who have witnessed the meaning of Qur'ānic secrets such as "every thing is perishing except His face" or the reality of the Preserved Tablet and so on. These affinities lie in the fact that, for al-Ghazālī, all knowledge has its source in the eternal knowledge of the Preserved Tablet.

However, the relationship between God and humans has, for al-Ghazālī, three levels:

1 The level which is presented directly in parts of the Qur'ān, lying mainly in the five pillars of Islam. At this level ordinary believers give assent to what the prophet revealed and have the hope of a future life in paradise. ${ }^{169}$ At this level there is no direct relationship with God.

2 The second level, expressed in the metaphorical passages of the Qur'ān concerning God and the divine world. At this level the ordinary Sufi travellers, al-salikin, are able through the purification of the soul to be granted some visions about such things as the meaning of repentance, the unity of God and the nature of love. The hope of the Sufis at this level is to enjoy love, friendship and nearness to God.

3 The third and highest kind of relationship, where the Sufi saints are able to analyse, through their previous acquired knowledge, and experience, the esoteric secrets of the Qur'ān about the essence of God and the angels in such terms as "every thing perishes except His face" (28:88), or the true and deeper meaning of the concept "there is no god save God" or the Hadīth "I become his ears by which he hears and his sight by which he sees." ${ }^{\prime 70}$ At this level the Sufi unveils the meaning of the divine Throne, the Chair and the Preserved Tablet as different ranks in the hierarchy of angels. The main hope of the Sufis at this level is to have a unified fellowship with the divine presence and to meet God face to face.

Some scholars with sufficient depth of knowledge reach a similar level through their unremitting pursuit of acquired knowledge, as al-Junayd probably did. However, they do not enjoy an actual sight of God but rather a full understanding of who He is.

Thus, acquiring philosophical knowledge in al-Ghazālī’s system is perfected through the mystical experience of fan $\bar{a}^{\prime}$ and $i t t i h \bar{a} d$. 


\section{Comparison and evaluation}

Having examined some of the ways in which three thinkers of the tenth or eleventh century attempted to build bridges between humans and God, we can now compare and evaluate their views in to order to clarify which are the points of agreement between them and which are those of dispute. This chapter will be divided into two sections: the first, divided into three sub-sections, compares the concepts of God, human nature and knowledge and the different forms of relationship between God and humanity in 'Abd al-Jabbār, Ibn Sīnā and al-Ghazālī. The second section evaluates the different ways of understanding the relationship between the human and the Divine and offers some conclusions.

\section{God and humans in 'Abd al-Jabbār, Ibn Sīnā and al-Ghazālī}

\section{Their view on the nature of God}

We have observed in the previous three chapters that 'Abd al-Jabbār, Ibn Sīnā and al-Ghazāli do not attribute the same characteristics to God but rather picture Him in accordance with their respective theological, philosophical or mystical systems. My intention here is to compare and evaluate their view of the nature of God in two sections: the first analyses their concept of the essential attributes of God and the second treats in a similar manner the question of God's activities.

\section{God's essence}

'Abd al-Jabbār and the Mu'tazilites regard God as the only being who does not consist of atoms and accidents; all other beings and things are constituted from atoms, jawāhir, and accidents, $a^{r} r \bar{a} d$. The essence of God, therefore, is not subject to change, for change in this theological system happens through the succession of accidents in the body. God's attributes do not function as they do in humans to denote certain changes which occur, identifying either a temporary or a permanent state. Instead, His attributes demonstrate His real essence; 
some of them express His permanent states while others demonstrate the qualities of His actions which are connected to our world and hence are not eternal features in Him. Identifying this division between the nature of God and the nature of everything else in the world enabled the Mu'azilites to defend the transcendence of God without denying His Qur'ānic attributes. But Ibn Sīnā and al-Ghazālī recognize great similarities between God and the world. The world, for Ibn Sīnā, is in its overall system a divine emanation; the real essence of all things emanated from God and the divine world, while the main difference between God and the world lies in the nature of their existence. God possesses a necessary existence, whereas the world receives its existence from God. Al-Ghazāli finds the similarities between God and the world in his concept of the soul. The soul's nature, he considers, is similar to the nature of God and the way to have real knowledge of God starts when humans can be purified so as to recognize their real essence as part of God's. Here we recognize two aspects of God's nature: the one seen by the theologians who distinguish between it and the nature of the world, and the other recognized among the philosophers and the mystics who identify great similarities between God's nature and the nature of the world, in that the world is an emanation or a shadow reflecting the nature of God and the divine world.

Concerning God's attributes, 'Abd al-Jabbār and al-Ghazālī assert that God is known to us through His act of creation. This act proves Him to be able, knowing, existing, living and perceiving because a wise action such as creating the world must have been performed by an able agent who possesses wisdom and therefore can be said to exist and live. Although both theologians attribute similar qualities to God, al-Ghazālī was not apparently interested in discussing whether these attributes exist in the essence of God or are eternal notions which neither exist in God nor outside Him, as the Ash'arite school believed. This is because he regards all these attributes as ideals which enable humans to perceive what God is like; who God really is can only be experienced, according to al-Ghazālī.

In contrast, God's main feature for Ibn Sinnā is the necessity of His existence; however, he also attributes to Him pure intellect, goodness and love, which he identifies in the process of emanation. Ibn Sīnā, like 'Abd al-Jabbār and al-Ghazālī, considers that God is immaterial and unchangeable, but regards His intellect and love as mainly concentrated on Himself and His closest angels. This conclusion, however, derives from his own perception of the concept of "eternity" qidam, ${ }^{1}$ which to his mind means not only "having no beginning" but also "remaining strictly unchangeable." Thus, eternal knowledge, for example, is the knowledge which knows only the unchangeable and permanent features of things, and therefore the eternal knowledge of God cannot know the changeable features of things, rather only their unchangeable qualities. We saw above that the eternal knowledge of God, for Ibn Sīnā, means knowing only the universal qualities and not the transient ones. ${ }^{2}$

For 'Abd al-Jabbār, in turn, eternal attributes are attributes which are not caused by an accident but which exist within the essence of God, while for 
al-Ghazālī they may be defined as uncaused. But both believe that the main feature of eternal attributes is that they are able to accomplish all possibilities in their field; for example, eternal knowledge circumscribes all that can be known, exactly as eternal ability denotes the ability to do all that can be performed. This means that eternal knowledge includes the past, present and future and knows everything in all its changing states, thus denoting the omniscience of God. ${ }^{3}$ Al-Ghazālī, also, in his criticism of the philosophers in Tahäfut, shows that the eternal knowledge of God knows things in all their changeable features from eternity, but even when these changes occur they do not cause a change in Him, for these changeable features are included in His eternal knowledge. ${ }^{4}$

This was precisely the point on which Ibn al-Rushd criticized al-Ghazālī. He argued that eternal knowledge deals mainly with abstract concepts or those which are drawn from changeable things but are themselves permanent in nature. ${ }^{5}$ In addition, all things for Ibn Sīnā have two sides, one changeable and one permanent; the latter discloses the lasting features which it shares with others under the same species. These permanent features correspond with the eternal notions which have emanated from God and denote the unchanging qualities of all things, as outlined in Ibn Sinnā's theory of knowledge (see Chapter 3, sub-section titled "Ibn Sīnā's theory of inspiration"). Thus "eternal," to the philosophers, mainly means "unchangeable in features," while to "Abd al-Jabbār and al-Ghazāl̄̄ it means both being uncaused and having within itself all the possibilities which come under its field. Knowledge which includes past, present and future in itself is not subject to change when those events actually happen. Thus, for al-Ghazālī and 'Abd al-Jabbār, the oneness of God means that He is not subject to change from outside Himself but is able within Himself to perform all acts and to have the kind of knowledge, ability and perception which denote His omniscience, knowing all things in their changeable processes. However, in his late works al-Ghazāli demonstrates that all these attributes can only communicate what God may be like but not who He really is. Our minds will never be able to perceive God in His permanent state, but can only have an idea of who God might be through analysing and reflecting on His acts. His real essence can be known only through mystical experience.

In the above discussion we have emphasized two different ways of understanding the notion of "eternal": the philosophical and what we may call the theological. Both are ways of using the word "eternal." The philosophical way must imply that God as eternal can know Himself and what emanates from Him but only in a universal manner, which means that He cannot know the individual. The theological view considers "eternal" to mean "uncaused but including all possibilities within itself": God knows everything and can perform all kinds of acts and perceive all things in all their changes. The knowledge of the individual, for al-Ghazālī, is already included in God's eternal knowledge before this individual's existence; thus, the events of our lives and of the world are included in God's eternal knowledge. 
This reasoning leads 'Abd al-Jabbār to believe that God's will must be temporal because if it is eternal then He would have willed good and evil, which both come under willing; however, for him, God does only what is righteous and, therefore, His will cannot be eternal. On the contrary al-Ghazāli believes that God's will is eternal because He determines all that happens, both good and the evil, whereas Ibn Sinna does not attribute any will to God because in his view will denotes change, for one wills after being not willing.

As a result, God for all of them is immaterial and unchangeable; they all attribute eternal attributes to Him but they differ in what they mean by the term "eternal." Al-Ghazālī and Ibn Sīnā identify similarities between God and the world, while "Abd al-Jabbār considers that God and the world have two different natures which are incomparable.

\section{God's activity}

The question of God's activities caused serious difficulties not only to the Muslims but also to the Greek thinkers, starting with Aristotle, who limited God's role to that of the Prime Mover, and ending with Plotinus, who saw emanation as the only possible way in which God could bring the world into existence without performing an act. The reason behind this problem is that if God were to act then his essence would have to include change, as an inevitable result of His activities. Although Muslim theologians were influenced by Greek thought, they perceived God as an active agent who not only created the world but also continued to influence all its events. 'Abd al-Jabbār considers, indeed, that all our knowledge of God comes through studying His divine activities. The act of creation discloses His essential characteristics, while His other acts - of granting the divine law, assisting its achievement and finally rewarding the righteous and punishing the unbelievers - reveal His justice. Thus, the whole theology of 'Abd al-Jabbār rests on the concept that God is acting and influencing the increase of goodness and virtue in the world. In addition, he does not consider that God's activities cause a change in His essence, because a change, in his eyes, can only happen through the inherence of accidents, whereas God acts through Himself. ${ }^{6}$ Thus, God's acts reveal the effective role which He plays in the world and in human life.

In contrast, God's role in Ibn Sinnā's philosophy is reduced to the emanation of the First Intellect. Ibn Sīnā adopts the philosophical theory which says that the world emerged from God without violating the unity of His essence. In addition, Ibn Sīnā recognizes the logical difficulty of God's producing multiplicity and the material world when $\mathrm{He}$ is one and purely immaterial. ${ }^{7}$ All these problems lead Ibn Sīnā to adopt Plotinus' theory of emanation, which holds that the world resulted from God without His performing any act. However, Ibn Sīnā attempts to solve the problem of logically connecting God with the world through his theory of a third element, in addition to matter and form. He explains that, since God is the only necessary existent, then all existences must emerge from Him alone. This means that each thing which 
comes into existence, through the Intellects, receives existence directly from Him. ${ }^{8}$ However, this solution did not effectively relate God to human beings nor to the events of their history. Thus, God remains for Ibn Sinnā the power which is the cause of existence, but fails to have an effective relationship (by causing changes) with His product. Ibn Sīnā considers, however, that the important point here is the dependency of the world on God which emanation can still demonstrate. He explains that the world is always in need of God, but God does not need the world; therefore, the world must be satisfied with what the divine grants.

The question of God's activity is also of concern to al-Ghazālī. God, according to him, initiates all events and human acts. However, he says in some passages that God probably used the angels for creating the world, but the angels were determined to create according to God's plan and instructions. He also criticized the philosophers for their interpretation of God's unity, believing that it must lead to a static God who is not able to act because whatever He does must pass through the process which brings acts to their actuality.

God's activity here is very important in determining the kind of relationship which might exist between Himself and human beings. God's acts, for 'Abd al-Jabbār and al-Ghazālī, denote His relationship with humanity through His creation and guidance; however, 'Abd al-Jabbār considers that God grants guidance to humans to choose rightly, while al-Ghazālī considers that this guidance compels them to acquiesce in God's decrees. Thus, for 'Abd alJabbār, God's acts influence only the direction of the world towards goodness, whereas for al-Ghazālī God's activities necessitate and initiate all events. He explains in his Sufi writings that the highest Sufi stage is the stage of recognizing that while humans cannot influence anything, everything expresses the omnipotence of God. God is also not compelled to act in accordance with human wisdom and only $\mathrm{He}$ can know the wisdom of His acts. Thus, 'Abd al-Jabbār and al-Ghazālī both emphasize God as an active agent but they totally differ in interpreting the purpose of His activities and their effectiveness in human history.

Ibn Sinnā's view here is distinct from those of both 'Abd al-Jabbār's and al-Ghazālî̀s in two points: he does not recognize the importance of considering God as an active agent, since the world already has all that it needs from Him: existence, knowledge, goodness and love. In addition, the activities of God, he believes, would not affect the nature of events, since Ibn Sīnā considers that evil can only be done through human will, as explained in Chapter 3, sub-section titled "The function of religious knowledge." However, the activities of the ten Intellects accomplish all the needs of the world. Therefore, he considers that even if God were an active agent, the state of the world would not be better.

Thus, it would appear from the discussion above that the features on which all three agree have their source in Greek philosophy, and those where they differ indicate the actual direction of each one's system: Ibn Sīnā as a philosopher, 
'Abd al-Jabbār as a Mu'tazilite and al-Ghazālī as a Sufi philosopher. Greek philosophy supplies them with the rational ground and the argumentation for defending the oneness of God. It introduces the concept that God must remain unchanged, which influences them all to different degrees, as noted earlier in this section. However, they employ these concepts in different ways to build different systems. For 'Abd al-Jabbār, the oneness and unchanging features of God mean that God acts through the quality of what He is, but al-Ghazāli interprets this oneness and immutability to mean that God is the only real active Agent and that everything reflects His will. These qualities of God are the main reason behind Ibn Sinnās conclusion that God could not have created the world in time and that His relationship to the individual has to be subsumed under His universal knowledge. Therefore, we are faced here with three views of God: the first discloses a God who is wise, gracious and just, His acts all directed towards improving the world and increasing its righteousness. The second is One who is wisdom, goodness and love in Himself but cannot know the world because of His nature. His creation of the world was not the result of His willing, but according to His nature as emanating, fayya $d$. The third image reveals a God who controls and determines everything, whose wisdom cannot be known to us but rather experienced through the mystical ascent. These images, however, will be amplified after we have examined their effect on the three relationships evaluated below. Here, we examine the concept of human nature and knowledge in these three philosophers.

\section{Their views of human nature and the knowledge of God}

In Chapters 2, 3 and 4 we discussed human nature according to each of the thinkers and saw how they thought that knowledge about God could be attained. Here my intention is to draw their views together in order to demonstrate the points of agreement and disagreement between them. Thus, I shall divide this sub-section into two further divisions: the first examines their definition of the human essence and the ways in which they describe living and the existence of persons. The second explores their evaluation of human knowledge and perception. The aim of this sub-section, however, is to demonstrate the three scholars' concepts of the way in which people can know God; therefore, it will focus on the ways in which humans direct their minds to know the Divine.

\section{Human nature}

Humans are characterized as living beings, but here a question already arises: in what sense are they living? We saw that al-Ghazālī and Ibn Sinnā give the same characteristics to humans while 'Abd al-Jabbār describes human beings in the same way as most theologians, mutakallimün, of his time. He considers 
that human bodies consist of parts which have the two qualities of existing and occupying space. The body, however, cannot think or act; all human activities are caused by the inherence of the sequence of accidents which they receive. Human beings, to "Abd al-Jabbār, are composites of atoms and accidents which act in a unified way.

Ibn Sīnā and al-Ghazālī agree with 'Abd al-Jabbār that the body cannot think and initiate activities, but they consider that it owes its power to act to the existence of a soul. They both consider that the soul discloses the person, and they give it qualities similar to the divine. It is immaterial, indivisible, one and not located in any part of the body. It seems here, however, that Ibn Sinnās concept of the soul and its substantiality and distinctness from the body was the main influence on al-Ghazālì's concept of the soul. He was probably the first theologian to adopt a philosophical view of the human soul. They also agree that our utmost hope is to free the soul from the body. However, al-Ghazālīe as explained above, is inconsistent on this point: although he accuses the philosophers in Tahäfut of believing in a spiritual rather than physical resurrection, he maintains in his Sufi text in Ibya that the Sufis must struggle against the desires of the body and that they will reach the highest stages only when the soul is set free from any connection with the body in the stage of $f a n \vec{a}$. This agrees with his statement in Kitāb al-Arba'in which declares that rewards and punishments are spiritual. 'Abd al-Jabbār seems to reject the concept of the duality of the human soul and body precisely because it might lead to belief in a spiritual resurrection, on the basis of the importance given to the soul by some philosophers and Sufis. He himself considers that the soul is only the air which we breathe.

Ibn Sīnā and al-Ghazālī also agree about the function of the human soul and its division into three main functions, to nourish, to feel emotions and to reason; they consider that the rational function is the highest and is divided into practical and theoretical reasoning. Thus, for both of them humans are guided by their intellect. 'Abd al-Jabbār, in contrast, does not consider that a human's power to reason belongs to any part of the body and he argues against the view that the intellect, $a l^{-} a q l$, is a substance in the body which has its own function. 'Abd al-Jabbār is concentrating in this argument mainly on the meaning of the word ' $\bar{a} q i l$, rational, which cannot be simply attributed to someone because he/she possesses the substance 'aql. Therefore, intellect, 'aql, must mean knowledge itself and not its location. Although this discussion was directed against the philosophers, it does not affect either al-Ghazālī and Ibn Sinna because for them it is less important what intellectuals are called than whether they possess knowledge or not. When they do, we must recognize a certain power in them which enables them to receive this knowledge and organize it in a way which reveals it as knowledge. This power they call the theoretical intellect, the highest quality of the soul.

However, Ibn Sinna considers that the human intellect exists in the body as a potential intellect and when it acquires knowledge then it can be called al-'aql bi-al-malaka and al-'aql al-mustafäd, acquired intellect. But al-Ghazālī 
considers that the human soul was created before the body and was informed of the existence of God and probably of His qualities. Thus, humans are born with a certain innate knowledge which is known in the Qur'ān as fitra. (see Chapter 4 sub-section titled "The human intellect and its functions")

However, Ibn Sīnā and al-Ghazālī consider that the utmost happiness that a human can reach is through the ascent of the soul towards a conjunction with the divine presence; in Ibn Sīnā's system, God has no effective role in this conjunction, but for al-Ghazālī God leads Sufis and manifests Himself to them. The utmost happiness for 'Abd al-Jabbār, however, is to reach the deserved reward in paradise. Humans in his theology will never at any time be able to see God.

As a result, we have here two main views of humanity. Ibn Sīnā and al-Ghazālī agree about the main features of the human essence, while 'Abd al-Jabbār differs from both. He, while rejecting the duality of body and soul, adopts another duality - that of atoms and accidents. Accidents in his theology replace the soul in tracing the capacities of humans but they do not present the rational unity which the soul presents. It seems to us that the Mu'tazilites and many other Muslim theologians realized the danger of supposing that human activities are related to a rational spiritual being, as this would have affected their whole theological system. For the rational soul, as described by the philosophers, must have qualities which are similar to God's, such as being immaterial, indivisible and one. With these qualities the soul cannot be satisfied by the promised rewards which concentrate on the pleasures of the body. The hope of the soul, as we have seen in Ibn Sīna and al-Ghazālī, is to meet God and have eternal life in contemplating Him. In a sense, the human soul may become like an angel, whose existence and hope differ totally from those of humans. Thus, belief in the substantiality of the rational soul raises humanity to a divine condition which has mystical implications and hints at the unimportance of the body in the life to come.

\section{Human knowledge}

All three scholars consider that humans are able to reach knowledge about God through revealed and rational methods. 'Abd al-Jabbār, however, relates this ability to the human responsibility to fulfil the divine law. For him mankind was created in a certain way which enables it to know God. Since God imposed obedience to the divine law on human beings, He must in fairness support them with everything needed to gain a knowledge of it. But Ibn Sinnā and al-Ghazālī regard human knowledge as a result of the existence of the rational soul. Here, however, we will compare their views of human knowledge through examining their views of the following: necessary concepts, immediate knowledge and religious knowledge.

Necessary concepts All three scholars make frequent use of the notion of perceptions and self-evident concepts which the mind knows without needing 
to learn them. 'Abd al-Jabbār considers that the existence of these concepts in the mind (together with the mind's store of immediate perceived ethical concepts) prove a person to be rationally mature. However, they all consider that this knowledge is the basis and the starting point for rational inquiry. All syllogistic methods, for them, depend on the existence of perception and self-evident concepts. All three writers also consider that ideas which come from the perceptions of the senses are reliable and can form the basis of inquiry. Thus, they all rely on the fact that enquiry into any issue starts from a certain truth, which is related either to non-contradictory, self-evident truth or to the real existence of something in the world.

Immediate knowledge Immediate knowledge, for all of them, is granted from the divine world in order to present basic truth to the human mind. 'Abd al-Jabbār, Ibn Sīnā and al-Ghazālī agree that the most important kind of knowledge comes through immediate reception of knowledge and they all build true human knowledge on this inspired kind, although they differ in their views of the methods of reaching such knowledge and its content. Accordingly, for "Abd al-Jabbār each theological issue must be related to a concept which is known to us in its general form through immediate knowledge, which he calls așl darüri. The responsibility of humans is to discover the details of this immediate knowledge, which declare the nature of the righteous act. ${ }^{9}$

For Ibn Sīnā, immediate knowledge is a kind of knowledge which is not given to every person but only to very few and is considered a natural phenomenon. This knowledge explains the ability of some people to receive clues, ideas and concepts from the Active Intellect. Although knowledge is given to few people, Ibn Sinnā considers that all knowledge is based on intuition, because this is the true knowledge which has its source in God and from Him emanates to the different Intellects and to us. Thus, this knowledge does not inform us in the sense of giving instructions (as suggested by 'Abd al-Jabbār's belief about the nature of immediate knowledge) or in the sense in which we know by revealed knowledge, but mainly unveils the nature of things to some people who are able through these universal concepts to build complete theories and construct scientific systems.

Immediate knowledge for al-Ghazālī is the knowledge which comes directly from the divine world. It is esoteric and therefore should be concealed from most people. The reason is that this knowledge mainly discloses the reality of the divine world and its connection with our world. It uncovers the secrets of the divine world. Like Ibn Sinnā, al-Ghazālī considers that this kind of knowledge concerns abstract and universal concepts, with their eternal, unchangeable qualities. However, for al-Ghazālī, this knowledge includes all that can be known about the past or the future, about God, the divine and the material world. It is the eternal knowledge of God which $\mathrm{He}$ keeps in the Preserved Tablet. Thus, it seems that all of them regard this knowledge as the voice of God which guides us in different directions. Humans should behave righteously and learn to discover the permanent 
features of things, but also realize that behind them all is a secret which the mind cannot uncover, except imperfectly. The divine voice expresses a dynamic revelation which is related to the individual at all times. We will refer to this concept once more in the section titled "Evaluation" later.

Religious knowledge We observed that all three scholars differ in their concept of the importance of revealed and religious knowledge. 'Abd al-Jabbār considers revealed knowledge to be a branch of rational knowledge, disclosing some commandments such as details of worship which cannot be learned through rational methods. But the real importance of revealed knowledge for him seems to lie in its power of assistance, lutf, to us in performing our rational obligations and confirming the reliability of the rational responsibilities, taklīf. 'Abd al-Jabbār does not consider that religion reveals knowledge which cannot be known through other methods, but it rather motivates righteous behaviour through assisting worship and prohibiting acts which lead to moral corruption, mafsada.

The main importance of religious knowledge for Ibn Sīnā is to demonstrate the existence of prophecy. The prophet, he says, possesses the highest kind of intellect, which he calls "sacred intellect"; however, prophetic intellect can also be created in persons who are not called to reveal messages, since a prophet, for Ibn Sīnā, is mainly a social and religious leader. Revealed messages, to his mind, not only reveal instructions for moral behaviour but also metaphorical concepts which can lead competent minds towards philosophy.

Although al-Ghazālī showed great respect for religion and for the Qur'ān, as shown by his many quotations and uses of religious terminology, he believes that religious knowledge unveils only a part of the divine knowledge of the Preserved Tablet. His mysticism is built on a belief in the existence of a secret knowledge which is revealed to some Sufi Saints, whom he calls 'ulüm al-mukasshafa. The source of this knowledge is the Preserved Tablet. Therefore, it seems that al-Ghazālī believes in a knowledge which is beyond religious knowledge. Religious knowledge, as Ibn Sīnā conceives it, is revealed by figurative language mainly to the masses; for the elite are reserved the esoteric parts of the Qur'ān and the 'ulüm al-mukāshafa. He uses this term to refer to the sciences which give a dynamic revelation of and everlasting connection with the eternal knowledge of God. They are also the only way to interpret the esoteric parts of the Qur'ān, in his eyes the deepest and most important part of religion.

Thus, it seems that 'Abd al-Jabbār and Ibn Sīnā do not give great importance to religious knowledge as "the source" of knowledge, but they agree that its most important function is to demonstrate the importance of worship. However, 'Abd al-Jabbār does not consider that the human intellect discloses more information than what has been revealed, nor that the revealed information goes beyond what the mind discovers in rational takliff. Thus, for him there is total harmony between reason and revelation: all that the mind discovers is revealed and all that is revealed is within what can be rationally perceived. The question which arises here is: what is the importance of the 
rational taklif when the revealed one can fully replace it? 'Abd al-Jabbar's answer probably would be that religious takli $f$ is given to some, while rational taklîf is a universal responsibility. Furthermore, religious knowledge can only be fully perceived through the rational interpretation.

'Abd al-Jabbār does not divide ordinary folk from the elite, an important feature of al-Ghazālī and Ibn Sīnā's philosophy, probably because, for him, there is only one goal for all humans to aim at, which is to perform the divine law and receive the deserved reward. For Ibn Sīnā and al-Ghazālī, in contrast, this is the goal of the masses; they both confirm that there are, in addition, some who wish to know the reality of the world and to make contact with the divine presence.

To conclude this section on human beings, we observe that although 'Abd al-Jabbār, al-Ghazālī and Ibn Sīnā confirm the importance of human knowledge and its reliability, they differ in defining human capacities. Al-Ghazālī and Ibn Sinna believe in the existence of the human rational soul which controls the body and leads to the apprehension of higher truths. For 'Abd al-Jabbār, the divine law clearly emphasizes humans as composite beings who, in this life and the next, will be rewarded by the kind of benefit which satisfies the body, as one part of the composite person. Therefore, the resurrection of the body has an important role for human beings, according to 'Abd al-Jabbār.

Human knowledge for all of them is reliable only because it can depend on divine assistance. All three believe that human beings cannot reach a knowledge of God on the basis of their own rationality alone; they all declare the importance of divine assistance in acquiring knowledge. This point will be further analysed in the section titled "Evaluation" later in this chapter.

\section{Evaluation of the three writers' views on the different relationships between the human and the Divine}

In this part of the chapter we will attempt to demonstrate the similarities and differences in the views of these three scholars concerning the relationship between the human and the Divine. Our aim here is not simply to show which of these relationships is best or most consistent but, more importantly, to evaluate the three ways as three possibilities of reaching the Divine. Therefore, this sub-section will be divided into three divisions, each evaluating one of the relationships which were presented above in Chapters 2, 3 and 4. Then, a short comparison between the three will follow.

\section{Divine assistance, luṭf}

The relationship between God and humans in 'Abd al-Jabbār's theology is very closely related to his understanding of the nature of God and humanity. In his discussion of the attributes of God, he treats the essential attributes as real qualities which must exist in God's essence and enable Him to act in 
accordance with what $\mathrm{He}$ is. In contrast, human beings in his theology, consist of parts which are unified through the accidents which inhere in them. Rejecting the independent existence of the human soul and asserting the initiation of human activities through the inherence of accidents has two results: the first is that human nature is posited as basically different from divine nature and therefore there is no hope of becoming God-like because God, according to this view, has created humans as they are, with their specific nature, as a composite of atoms and accidents. The second result of the absence of the human soul is that humans can only hope to have a better life in paradise, in the sense of enjoying every pleasure and luxury, but cannot think of having spiritual rewards or hoping for eternal happiness in the divine presence. In addition, 'Abd al-Jabbār also considers that paradise for humans will offer no choice between good and evil; therefore, it will probably contain only material pleasures.

Our aim here is to demonstrate two points: the first is 'Abd al-Jabbār's belief in the utter unlikeness of God's nature to human nature, and the second is that this dissimilarity must affect the relationship between God and humans. As shown above, this concept of humans rejects the possibility of both spiritual resurrection and the hope of living in the presence of God in paradise. Hence, this concept does not lead to a mystical relationship between God and human beings, which is dependent on similarities between the human soul and God, as both Ibn Sīnā and al-Ghazālī describe. Therefore, 'Abd al-Jabbār's theology aims at a relationship which emphasizes the importance of the divine law, presenting humans with the possibility of earning reward. However, the inner importance of the divine law leads to an understanding of the value of goodness and the evilness of evil. Thus, humans can recognize God in their recognition and apprehension of goodness. God's role in this relationship is to guide and assist humans in different ways. In Chapter 2, earlier, the different forms of divine assistance were listed: first, God's granting the divine law in both rational and revealed forms, second, God's providence of tamkin (perception and necessary knowledge) also, to qualify humans as rationally responsible and grant assistance through different warnings of the danger of not reflecting. However, although, according to 'Abd al-Jabbār, God's assistance should not be considered the same as a personal relationship with Him, the divine warnings (through words or through sufferings) or the gift of peace to the mind (sukün al-Nafs) when people reach the right concept demonstrate, to an extent, a personal relationship.

In 'Abd al-Jabbār's theology, as a result, humans have a limited personal relationship with God through the direct assistance (inspiration) which reaches individuals and leads them to rational reflection. This, I believe, is strongly influenced by the unlikeness which he perceives between the nature of the human and that of the Divine, which limits human hopes to the material pleasures of paradise so long as they obey the divine law. Humans accordingly cannot hope to have a direct experience of God, even in paradise, because, in the view of 'Abd al-Jabbār, God can be perceived neither through 
sight nor through a vision of the heart. Thus, humans must be content to know God only through His acts or His laws but never to have personal communication with Him.

\section{Divine love, 'ishq}

Ibn Sīnā presents in his philosophy a coherent system which consistently leads to two different kinds of relationship with God, both governed by the presupposition that God cannot know the individual characteristics of each human. God here cannot have direct communication with the individual, partly because His nature is unchangeable and absolutely one, but also partly because of the nature of His eternal knowledge. This kind of knowledge, as outlined in the chapter on Ibn Sinnā's philosophy, embraces only the features of things which are not subject to change. However, the world is connected to God through Ibn Sinnās use of the theory of emanation. All existence, knowledge, love and the overall world system flow out of the essence of God and share those qualities with Him.

Human relationships to the divine world fall under two kinds of possibility: the illumination of the human intellect through the Active Intellect and the direct conjunction of the human soul with the eternal light of God, either in this life or after departing from this world.

The human theoretical intellect has great similarities to the Intellects because of its ability to perceive universal eternal knowledge. Ibn Sīnā pictures the relationship between God and His Intellects as a mutual current of knowledge which flows from God and is enjoyed by the Intellects. When humans are inspired with universal knowledge, they perceive this relationship and become indirect partners. Thus, at this level of relationship, the human theoretical intellect can enjoy an indirect relationship with God through His knowledge. However, Ibn Sīnā also explains in some of his works the concept of tajalli , which sees God from a different standpoint, not mainly as the source of knowledge but also as the source of love.

In The Treatise on Love and the last chapter of Remarks and Admonitions he concentrates on these latter characteristics of God. In the relationship described above, we saw how knowledge governs the communication between God, His Intellects and the theoretical intellect of humans. Now Ibn Sīnā describes God as a great power of love which radiates from His selfmanifestation, tajalli . This love emanates from Him to all creatures, building a direct relationship of love between God and His Intellect, as outlined in Chapter 3. Having discovered this side of the relationship between God and the intellectual world in The Treatise on Love, Ibn Sinā investigates in Remarks and Admonitions whether the human intellect can stand beside the Intellects in enjoying a direct relationship with the divine self-manifestation, tajallī.

Here, Ibn Sīnā realizes that, to reach this kind of relationship, humans need to do much more than master universal conceptual knowledge. It seems 
to me that Ibn Sinnā adopts the view that, just as knowing the intellectual side of God comes through knowledge, so experiencing His love must come through love, 'ishq. Thus, the way forward here does not depend on knowledge, though he regards this as a basic quality possessed by the knower, but rather on mystical experience and a mystical ascent. We have seen that in his description of the mystical path he follows to a great extent the Sufi stages of repentance, hope, patience, asceticism and love. ${ }^{10}$ He probably considers that this Sufi ascent is the best method for guiding the soul, with full concentration on God's love as its only goal. However, he does not go into much detail about the nature of these stages and it seems that he would accept other methods if they were more effective in reaching a full perception of God's tajalli. Thus, his intention here is not to study Sufism but only to use its system to reach conjunction with the divine tajalli. It seems also that his aim is not to describe how unity between the mystic and God is attained, because his philosophy does not lead to such a concept: God as the unknowable Necessary Existence cannot be united with a possible existence, and humans can never share the kind of necessary existence which God has. In addition, Ibn Sīna argues against the unification of the active Intellect with the human intellect, explaining that two entities cannot become one, as mentioned in Chapter 3, sub-section titled "Relationship with God's tajallï".

Although Ibn Sīnā's metaphysics is solidly based on the hierarchical system which sets each being in its determined place, he concedes that some humans can hope to have the same eternal enjoyment of God's presence as the Intellects. Thus, the relationship between God and humans in his philosophy depends on the status of the human soul and specifically on its theoretical intellect. However, in neither relationship, whether through knowledge or through love, does God recognize specific persons. Perhaps, when the human becomes an intellectual soul after the death of the body, God will know it in its permanent qualities but not in the sense that it belonged to a particular individual. Thus, although Ibn Sīnā attempts to reach the closest kind of relationship with God while retaining the consistency of his system, his 'ish $q$ remains different from that of the Sufis who experience it in their conviction that God knows, loves and guides them. However, Ibn Sīnā would probably insist that the result of this relationship, a full conjunction with the divine presence, is in no way different from the Sufis' experience of the manifestation of God's tajalli. Nevertheless, there is no motivation to reach this stage in Ibn Sīnās mysticism.

\section{Annibilation, fanā'}

After pointing out the problems raised by Ibn Sinnā's view of mystical love, 'ishq, we move here to evaluate al-Ghazālîs's love toward God, which leads to the death of self, fan $\vec{a}$. The relationship between God and humans in al-Ghazālî's mysticism is built upon two main concepts: the mystery of the essence of God and the similarity of the human soul to the divine nature. 
First, we will discuss al-Ghazālī’s concept of the mystery of God and then turn to examine the importance of the similarities between the human soul and God. Al-Ghazāli in the course of his writing criticizes the image of God which is discussed by both philosophers and theologians, al-mutakallimūn. In his criticism of the theologians at the end of Mishkät he explains that the attributes which they predicate of God cannot possibly present all the truth about Him, because if we believe that God is as the Qur'ann reveals in the verse "Nothing whatever is like unto Him" (Q. 42:11), then we have to believe that these attributes have no aim but to create an image of God which humans might perceive.

In the last chapter of Mishkat, al-Ghazālīs criticism of both the philosophers and the theologians' image of God is probably, in view of the above criticism, meant to demonstrate that God is a mystery whose reality cannot be perceived by human rational qualities because His reality is self-evidently higher than the human intellect. This, however, far from discouraging al-Ghazālī, only confirms his belief in mystical experience. Since the concept of God presents a mystery, then neither rational nor theological methods can reach it. This is what he clearly declares in al-Munqidh; however, he also shows that this mystery was not demonstrated to a certain Imam, as the Isma ‘i lis believe, but is revealed only to purified souls who have a yearning to meet God. We conclude here that one of the solid bases of al-Ghazālī's mysticism is his belief that God is a mystery which cannot be reached by the human intellect nor through the attributes which are revealed in the straightforward precepts of the Qur'ān (since the Qur'ān asserts that nothing is equivalent to Him), nor through rational philosophical methods.

The nature of the human soul, however, is created similar to that of God, as he explains in Alchemy, in order for it to perceive God's nature (according to the Greek concept of like knowing like). He also mentions here the covenant between God and all humans in Qur'ān 7:171, in which God manifested Himself to human souls before the creation and made them testify to their knowledge of Him. Here it is very important to see that al-Ghazālī considers that the purpose of this covenant is not to direct humans to do good or to obey God's law, but mainly to affirm that human souls can know the nature of God and are directed to seek this knowledge in their earthly life. However, al-Ghazālī's main purpose in his presentation of the nature of the human soul in Alchemy is to prove the Hadīth: "he who knows himself knows God." Therefore, the soul can know God because of its similar nature, which was deliberately created with the qualities which would enable it to recognize God. Thus, al-Ghazālîs's mysticism is based on the two concepts of the mysteriousness of God's nature and the similarities to it within the human soul. In order that the human soul may apprehend God, it must pass through its earthly life for the sake of gaining knowledge about Him. Thus, the aim of the Sufi here is to fulfil God's covenant and know Him with the same certitude as the human soul had in its experience of His manifestation before its life on earth. The utmost hope of the human soul is to fulfil its promise and 
to know God as He is in the experience of fan $\vec{a}$ ' and union ittib $\bar{a} d$, in the sense of entering into His presence, as al-Ghazālī says in Mishkāat (see Chapter 4, sub-section titled "God of the Sufi saint according to al-Ghazālī). However, al-Ghazāli explains that fan $\bar{a}$ ' is the total death of the self from the world; yet there is also a higher stage, which he calls fan $\vec{a}$ al-fan $\vec{a}^{\prime}$ which means being also dead to one's own self. If we think about the meaning of $f a n \vec{a}$ ' al-fan $\vec{a}$, we come to the conclusion that at this stage the soul must be so completely absorbed by the presence of God that it no longer has any individuality and disappears into the magnificence of the divine presence. Thus, his acceptance of $f a n \vec{a}^{\prime} a l$-fan $\vec{a}^{\prime}$ leads, in fact, to a relationship of unity where the human is totally absorbed in the Divine. However, al-Ghazālī's intellectual analysis is not able to accept that two entities can become one, although he declares in many places that our relationship with the Divine is mysterious. Yet it seems that al-Ghazālī can accept this mysteriousness to the extent that which does not contradict our rational capacity.

\section{Luṭf, 'ishq and fanā'}

We observe in the above evaluation that the different ways of comprehending the human and the divine nature modify our understanding of the relationship which might exist between them. The dissimilarity between human and divine nature in 'Abd al-Jabbār's theology precludes any mystical or personal relationship. To him, the relationship is based on the belief that God creates humans, whose nature is unlike His, in order to reward them with the pleasures of paradise; in return, humans should prove that they understand good and evil, and choose the former. However, "Abd al-Jabbār does not take into account the possibility that the divine law could prepare human nature to have some similarities with God, and therefore to enjoy in paradise the awareness and vision of His presence.

Ibn Sīnā, for his part, recognizes the similarities between the theoretical intellect and the divine Intellects and God but, unable to concede that God could know individuals, his account of mystical relationships is bound to be unsatisfactory. In what sense might mystics love God if they knew that God could not apprehend their love? We also do not observe any mysteriousness which might lead to a new discovery in the nature of God, as far as Ibn Sīnā is concerned. Mystics such as al-Hallāj and al-Bisțāmī pictured the relationship between the human and the divine as a mysterious one in which the human being discovers the real nature of God and the secret of union. Ibn Sinnā, in contrast, seems to have a clear idea about God and presents Him in a highly rational form which does not allow any exception to our rational apprehension of His nature. At this point Ibn Sīnā reaches the limits of rationality and presents a consistent mystical relationship with the divine, as far as his rational capacity can accept such a thing.

Unlike Ibn Sīnā, al-Ghazālī demonstrates the similarities between the human and the divine nature on the basis of God's omniscience and omnipotence, 
which demonstrate His knowledge of each creature. His thesis that God is more mysterious than our rational faculty can grant shows the importance of seeking knowledge through mystical experience. Thus, the similarities between the divine and the human, which are built on the omniscience of God, allow a mutual personal relationship in which humans are seeking to reach their inner spirituality so as to recognize God's nature, while God simultaneously draws to Himself the sincere Sufis whose souls have attained comprehension of the divine world.

We conclude here that perceiving the human and divine nature is the key to comprehending the relationships which form between them. If there are no similarities between the two, then the relationship is limited to obedience to God's laws leading to a better life hereafter. If there are similarities but one is not able to recognize the other, then the relationship between God and the human is unsatisfactory. But when the similarities between them are based on divine knowledge and God's intention to enable humans to reach the level of comprehending the divine qualities, then it may lead to a mutually satisfactory relationship in which humanity is invited into the divine presence.

\section{Evaluation}

So far, we have observed the diversity in the three Muslim scholars' understanding of the nature of God, human essence and knowledge and their different understandings of the relationship between the human and the Divine. Here I shall attempt to show the lines which relate them to one another through their method of research. To do so, I will examine their concept of immediate knowledge and link it with what we can call dynamic inspiration, in order to explain the importance of the direct relationship with God which they all expressed, as will be discussed below.

We have observed in different chapters ${ }^{11}$ that all three authors based their rational methods on inspired knowledge. They all discovered a direct way of communication with God and the divine world which provides firm certain knowledge. 'Abd al-Jabbār expressed the direct communication with the Divine through his concept of warnings, khawätir, pain and suffering which are caused by God, necessary knowledge and the tranquillity of the soul, sukūn al-nafs. The concept of immediate knowledge in 'Abd al-Jabbār's theology seems from the Sharb to have been widely accepted among all Mu'tazilites. They considered that what all people agree about is perceived by the immediate kind of knowledge which inspires the human mind with true concepts, such as that wrongdoing and lying are evil, al-zulm qabīh. This concept probably had its origin in consensus, ijm $\bar{a}^{\prime}$, and original thought, ijtiha $\bar{d}$, which allowed scholars in the early Islamic period to decide what should be included in the Hadiths ${ }^{12}$ or which version of the Qur'ān should be authorized universally. However, exploring the link between these two concepts and 'Abd al-Jabbār's concept of divine assistance requires a separate study. Here, in fact, we can only note that the ijm $\bar{a}^{\prime}$ and $i j t i b \bar{a} d$ of the early period 
probably provided the starting point for finding truth without being fully dependent on the Qur'ān.

However, 'Abd al-Jabbār also emphasizes the importance of the divine warnings, such as khawātir, and pains and sufferings as a preparation and motivation for reflection, as is outlined in Chapter 2 sub-section titled "Divine assistance through the warnings of khawätir" and "Warning through pain and suffering." But he seems to be the first of the Mu tazilites to lay great emphasis on these two concepts as demonstrating God's assistance to humans; the Sharh, which 'Uthman considers to be Mankdimm's presentation of 'Abd al-Jabbār's lectures, pays little attention to these concepts. In contrast, these two concepts play an important part in al-Mughni 12 and 13 in demonstrating the divine assistance, luff. These warnings motivate rational adults to reflect and construct their own way of perceiving God, human nature and the relationship between them. Sukün al-nafs, however, seems to have had significance for all Mu'tazilites from the discussion of al-Mughnī 12, confirming the correct conviction. However, 'Abd al-Jabbār drew attention to the immediate way of receiving sukün al-nafs which makes this concept comparable to immediate knowledge. Therefore, it seems that God, for him, confirms correct conclusions through sending peace to the mind and soul, as outlined in Chapter 2, sub-section titled "The rational approach to God". Thus, although 'Abd al-Jabbār inherited the concepts of khawațir, pain and suffering which are sent from God as warnings, necessary knowledge and sukün al-nafs, he understood the importance of these concepts as demonstrating divine inspiration to the individual.

Ibn Sinās's concept of intuition also demonstrates divine inspiration to the human intellect. This concept, however, also expresses al-Fārābî̀s concept of intuition, which comes as a result of possessing the highest knowledge, in al-'aql al-mustafād. Fārābī explains the process of knowledge as a process of abstracting intelligibles from their material context and constructing different kinds of knowledge. When scholars reach a certain high level of knowledge, which he calls al-'aql al-mustafäd, they become able to receive inspiration from the Active Intellect. ${ }^{13}$ (However, the comparison between the concept of intuition in Ibn Sīnās and al-Fārābīss philosophy would require more investigation, which cannot be entered into here.) Ibn Sīnā, however, fully modifies this concept and shows that the perception of abstract concepts is fully dependent on inspiration from the Active Intellect. This demonstrates Ibn Sīnāss deep belief that all abstract and divine knowledge is revealed to the mind by means of direct communication between the human intellect and the divine Active Intellect, as outlined in Chapter 3, sub-section titled "Ibn-Sīnā's theory of inspiration." $\mathrm{He}$ considers that all kinds of knowledge originate either in the intuition which some scholars are able to receive, or in the revealed knowledge which the prophetic sacred intellect directly receives from the divine world, as outlined in Chapter 3, sub-section titled "The function of religious knowledge."

Al-Ghazālī was no doubt expressing a direct relationship with the divine world in his concept of revealed sciences, 'ulüm al-mukäshafa. This kind of 
knowledge is mainly based on visions which the Sufi receives in the highest stages, maqāmāt, of the mystic path. Sufis before al-Ghazālī, such as al-Junayd, al-Bisțāmī and al-Hallāj, considered mystic visions as the only way of knowing God and having a relationship with Him. Ecstasy, mukāshafāt, was for al-Hallāj and al-Bisțāmī the way to attain full identification with God, while for al-Junayd it seems to illuminate the mind with divine secrets. Like al-Junayd, al-Ghazālī expressed these mukāshafāt in his concept of 'ulüm al-mukāshafa which present certainty, yaqinn, to the mind. This certainty, he believes, explains the mystery of the world which rational methods cannot reveal and the Qur'ān only hints at in different metaphors. But in addition 'ulüm al-mukäshafa inspire the mind with truth about the material world and its relation with the divine world. They also unveil the reality of the angels and their ranks and functions. Thus, these revealed sciences provide the Sufis with philosophical knowledge which reveals the wisdom behind the material world.

However, although all three scholars devote attention to the inspired knowledge which is provided directly to the mind, they demonstrate different approaches to this knowledge. 'Abd al-Jabbār links divine assistance and immediate knowledge with the necessity of the divine law: when God imposes a divine law, He should also provide the needed assistance. Ibn Sīnā's approach to inspired knowledge is different from 'Abd al-Jabbār's. Inspired knowledge, for him, unveils both scientific knowledge about the material world and esoteric knowledge and love of the divine world. Al-Ghazālî̀s mystical approach to inspired knowledge takes mainly the form of visions which the Sufi receives at a certain stage, maqām, of the mystic path. These mystic visions unveil the secrets of the divine world in its relation with the material one. The highest visions, however, disclose the reality of God's nature and are the highest form of relationship with Him through fan $\bar{a}$ ' and union.

Inspired knowledge here, however, is defined differently by the three thinkers: for 'Abd al-Jabbār it is the divine assistance which leads to knowledge of the divine law, rational taklîf; for Ibn Sīnā it is on the one hand the clue or the key to concepts and on the other hand it is the love which illuminates the soul and mind of the knower. This kind of knowledge for al-Ghazāli is esoteric and is revealed only to some few Sufis.

Hence, all of them assert the importance of direct contact with God or the divine world in apprehending and making use of this relationship, which demonstrates the divine voice and is a dynamic inspiration guiding souls to the divine way of perceiving the world. Thus, while in the first section of this chapter we showed the diversity of 'Abd al-Jabbār, Ibn Sīnā and al-Ghazālī's concepts of God, human nature and knowledge and the relationship between them, in this section, however, we have attempted to follow the thread which connects them all together through the concept of dynamic inspiration.

The relationship between God and human beings is mainly seen here as a dynamic inspiration and a continuation of revelation, which not only reveals God's knowledge, love and will to humans but also reflects the yearning of 
humans to reach the divine either in the form of appreciated rewards, or directly by perceiving divine knowledge and experiencing divine love.

\section{Conclusion}

Thinkers from the eleventh century exhibit diversity in interpreting the Islamic revelation of the relationship between God and humans. One relationship shows the importance of following the divine law through divine assistance which aims to reward humans with deserved benefits. The second discloses a relationship of knowledge and love which aims at a direct relationship with the truth in God's manifestation, tajallī. The third shows a relationship through the soul's ascent to its annihilation in the world and new life in God.

This diversity is partly due to the different facets of the Qur'ān's treatment of this subject, which influenced the thoughts of 'Abd al-Jabbār, Ibn Sīnā and al-Ghazāli in various ways, and partly due to the scholars' different interpretations which are based on inspiration. The main importance of these three scholars is their interpretation of revelation through inspiration. The conflict between reason and revelation is solved here through demonstrating that reason is essentially inspired by the same source as revelation and therefore must be in harmony with it. Thus, inspiration is both a continuation and an explanation of revelation and is the dynamic communication with the divine world.

Indeed, our three scholars here demonstrate a new concept of revelation: humans do not only accept divine guidance but also interact with it. They must first admit their need for it and then place it within the process of the knowing. This kind of guidance is also strongly supported in the Qur'ān. There are many verses which refer to the assistance of angels in guiding humans to believe and the assistance of a holy Spirit is also mentioned such as "Say, the Holy Spirit has brought the revelation from thy Lord in order to strengthen those who believe" (16:102), "For such (believers) He has written faith in their hearts and strengthened them with a spirit from Himself" (58:22), and "By His command doth $\mathrm{He}$ send the spirit (of inspiration) to any of His servants He pleases, that it may warn (men) of the day of mutual meeting" (40:15). ${ }^{14}$

We have attempted here to interpret different aspects of the Islamic revelation of the relationship between human beings and the Divine and have also begun to explore the importance of the human soul in its relationship with the Divine. We have noted the importance of immediate knowledge, which can be seen as a dynamic inspiration, in being a form of direct communication with the Divine. We hope that this may challenge others to study these two concepts more thoroughly. 


\section{Notes}

\section{Introduction}

1 Y. Yousf 'Ali, The Holy Qur'ān, London: The Islamic Foundation, 1975. See also 55:26-7, 34:4.

2 See also 2:77, 85:9.

3 See also Q. 38:72, 32:9, 66:12.

\section{Historical and cultural context}

1 Philip Hitti, The History of the Arabs, London: Macmillan Press, 1970, p. 466.

2 Ibid., pp. 467-8.

3 Ibid., p. 469.

4 Ibid., pp. 453-60.

5 Ibid., p. 509.

6 Ibid., pp. 461-72.

7 Ibid., pp. 461-2.

8 F. Umar, al-Khilāfa fì 'Ușüriha al-Mut'akhira, Sharqa: Dār al-Khalīj, 1983, p. 11.

9 B. Supler, "The Disintegration of the Caliphate in the East," in P. M. Holt, The Cambridge History of Islam, Cambridge: Cambridge University Press, 1970, Vol. 1A, pp. 144-7.

10 Hitti, History, pp. 470-1.

11 J. L. Kraemer, Humanism in the Renaissance of Islam, Leiden: Brill, 1986, p. 34.

12 Hitti, History, p. 471.

13 'Umar, al-Khilāfa, pp. 15-19.

14 Kraemer, Humanism, pp. 38-9.

15 Ibid., p. 49.

16 'Umar, al-Khilāfa, pp. 20-4.

17 Ibid., pp. 28-38.

18 Kraemer, Humansim, p. 37.

19 Hitti, History, p. 464.

20 Ibid., pp. 463-5.

21 'Umar, al-Khilāfa, pp. 79-89. See also Ibid., pp. 474-7.

22 W. Madelung, "Zaydiyya," Encyclopaedia of Islam, new edition, Leiden: Brill, 2002, Vol. 11, p. 477.

23 Kraemer, Humanism, p. 65.

24 Madelung, "Zaydiyya," pp. 477-9.

25 M. Heemskerk, Suffering in the Mu'tazilite Theology: 'Abd al-Jabbär's Teaching on Pain and Divine Justice, Leiden: Brill, 2000, p. 60. 
26 W. Madelung, "Ismā‘̂liyya," Encyclopaedia of Islam, new edition, Leiden: Brill, 1978, Vol. 4, pp. 198-206.

27 Kraemer, Humanism, pp. 60-3.

28 Ibid., p. 62.

29 S. H. Nasr, An Introduction to Islamic Cosmological Doctrines, Great Britain: Thames and Hudson, 1978, p. 178.

30 Hitti, History, pp. 464, 477-8.

31 Kraemer, Humanism, p. 53.

32 Heemskerk, Suffering, p. 38.

33 Kraemer, Humanism, p. 54.

34 Ibid., pp. 53-5.

35 H. Bowen, "Nizāām al-Mulk," Encyclopaedia of Islam, new edition, Leiden: Brill, 1995, Vol. 8, pp. 69-72.

36 Kraemer, Humanism, p. 56.

37 Ibid.

38 Bowen, "Niz̄ām al-Mulk," p. 72.

39 Heemskerk, Suffering, pp. 22-3. See also A. 'Uthman, al-Khiläf bayn al-Skaykhayn, Cairo, 1968, p. 62.

40 Heemskerk, Suffering, pp. 23-42.

41 Kraemer, Humanism, p. 264.

42 D. Gutas, Avicenna and the Aristotelian Tradition, Leiden: Brill, 1988, p. 116.

43 S. H. Nasr, Cosmological Doctrines, p. 189.

44 Kraemer, Humanism, pp. 172-3.

45 Ibid., p. 173.

46 Ibid., p. 237.

47 Ibid., pp. 172-4; see also the whole debate in Abū Hāyān al-Tawhīīī, al-Imtāa wa al-Mu'ānasa, ed. Ahmad Amin, Beirut: al-Maktaba al-'Așriya, 1953, Vol. 2, pp. 11-16.

48 Kraemer, Humanism, pp. 233-4.

49 Ibid., p. 170; see also al-Tawhīīī, al-Imtā', Vol. 2, pp. 6-7.

50 Kraemer, Humanism, p. 237.

51 M. Smith, Al-Ghazālī, the Mystic, London: Luzac, 1944, p. 15.

52 J. R. T. M. Peters, God's Created Speech: A Study in Speculative Theology of the

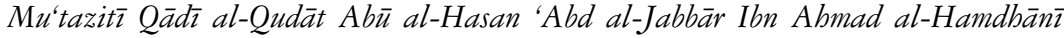
Leiden: Brill, 1976, p. 8.

53 Heemskerk, Sufferings, p. 37, no. 80.

54 Ibid., pp. 37-41.

55 Ibid.

56 'Abd al-Jabbār, Sharh al-Ușūl al Khamsa, Cairo: Maktabat Wahba, 1996, p. 40.

57 Ibid., pp. 14-15, see also Heemskerk, Sufferings, pp. 41-2.

58 Ibid., pp. 45-7, see also 'Abd al-Jabbār, Sharh, pp. 15-16.

59 Heemskerk, Sufferings, p. 47.

60 Ibid., pp. 48-9.

61 Ibid., pp. 52-3.

62 Ibid., see also 'Abd al-Jabbār, Sharh, pp. 19-23.

63 A. Dhanani, The Physical Theory of Kalām, Leiden: Brill, 1994, p. 9. Dhanani explains that the first one who directed attention to men's responsibility for their acts was Al-Hasan al-Bașrī (d. AD 728); however, Wāṣil Ibn 'Ațā’ (d. AD 748) and 'Amr Ibn 'Ubayd (d. AD 761), who were students of al-Bașrī, are considered the real founder of the Mu'tazilite school. Nevertheless, only from the time of Caliph Hārūn al-Rashīd (r. AD 786-809) did the school become well-known. They 


\section{Notes}

formed in fact two distinct schools: the Bașrian school under the leadership of $A b \bar{u}$ al-Hudhayl al-'allaff, (d. AD 841) and the Baghdadi school under the leadership of Bishr Ibn al-Mu'tamir (d. AD 825/840). Al-Nazām, who lived in the same period, seems to have belonged to neither of them. His opinions are closer to the philosopher than to the theologian, as we will attempt to show in this chapter. See, A. Badawi, Madhāhib al-Islāmiyȳ̄n, Beirut: Dār al-'Ilm lil-Malāyīn, 1983, p. 201.

64 Ibn al-Murtad̄ā, Aḥmed Ibn Yahyā, Firq wa Tabaqāt al-Mu'tazilah, ed. A. al-Nashaar, Cairo: Dār al-Maṭbu'āt al-Jami ‘iyya, 1972.

65 Peters, Created Speech, p. 10.

66 Abd al-Jabbār, Sharh, pp. 20-3.

67 Ibid., p. 20.

68 Ibid., pp. 26-8.

69 Ibid. 'Abd al-Karim 'Uthman describes this book as written in a clear and easy manner which aims to challenge the public and students, Sharh, p. 31. The importance of this book, besides explaining 'Abd al-Jabbār's theology in a sim-

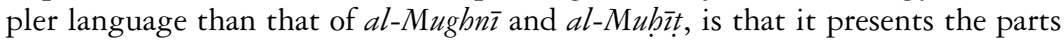
which are missing in al-Mughnī: the attributes of God, the promises and punishments and the commandments to do good and refrain from evil (which had not yet been published in al-Mubit $t$ ).

70 Ibid., pp. 155, 166, 174, 180, 216, 232.

71 This work was published by two scholars in 1965: J. J. Houben in Beirut: al-Matba'ah al-Kāthūlikiya,1965, and Sayd 'Azmi in Cairo; see Peters, Created Speech, p. 14. 'Azmi explains that the problem with this work is that Ibn al-Murtadā refers in al-Mañ̄h wa al-Amal only to al-Mubìt as a work of 'Abd al-Jabbār, but 'Abd al-Jabbār has also another work in Tafsīr which is called al-Muhitt. This work is mentioned in Mutashābih al-Qur'an. But Ibn al-Murtadā also mentions in the same book that Ahmed Ibn Mattawiyya, the collector of al-Majmü $\bar{f}_{\bar{\imath}}$ al-Mubìt bi-al-Taklīf, has a book with the title al-Mubit fì $U s \bar{u} l$ al-Dinn. Thus the question here is whether the Mubit bi-al-taklîf is the book of 'Abd al-Jabbār or not. 'Azmi, however, is convinced that this book includes all the ideas and theology of 'Abd al-Jabbār but it was not written at his dictation, which suggests that it is a secondary source. See Muhit t, pp. 7-9.

72 Peters, Created Speech, p. 14.

73 Ibid.

74 Ibid.

75 'Abd al-Jabbār, Sharh, pp. 39, 43, 45 and many others.

76 Peters, Created Speech, p. 15. Peters refers here to 'Abd al-Jabbār's own statement against one of his opponents,

May be some will say: what this book contains is only a compilation of what was known from the other books. (In answer): The question is not as he assumes; if you study it, there is no doubt that in every chapter of it nothing is left out: [there is] a wide-spread collection and a miscellaneous compilation, the explanation of the correct issue and a warning against sophism, (the argument of the opponents), the study of the condition of the indication and the definition of those things upon which the point and the correct issues are built.

See also al-Mughnī, Vol. 20, Part 2, p. 225.

77 Peters, Created Speech, p. 30.

78 Ibid., p. 33. 'Abd al-Jabbār explains here that the discussion on promises and threats will be postponed to the discussion of the revealed obligations.

79 We can see from the topics of the different volumes of al-Mughni which Peters presents that all the topics which come after Vol. 15 are connected with revealed 
knowledge. 'Abd al-Jabbār also declares at the end of Vol. 14 that he had completed the topics on the rational obligation, taklif 'aqlī, and would start on the discussion of prophecies. Nowhere else after this comment does he show any other kind of division. Peters, Created Speech, pp. 34-5; see also al-Mughnī, Vol. 14, p. 461.

80 Peters, Created Speech, p. 33.

81 'Abd al-Jabbār, Sharh, pp. 518-25.

82 See the list of topics of all the volumes of $M u g h n \bar{\imath}$ supplied by Peters, Created Speech, pp. 34-5.

83 The five principles of the Mu'tazilites are: (1) tawhìd, (2) 'adl, (3) al-manzal bayn al-manzalatayn, (4) al-amr bi-al-ma'rüf wa al-nabyy 'an al-munkar and (5) al-wa'd wa al-wa'i $\bar{\imath}$.

84 Gutas, Aristotelian Tradition, Leiden: Brill, 1988, pp. 23-9. See also S. Afnan, Avicenna, London: G. Allen \& Unwin, 1958, pp. 57-9; see also Ibn Sīnā’s own biography, The Life of Ibn Sina: A Critical Edition and Annotated Translation, ed. and tr. Gohlman, William E., New York: State University Press, 1974.

85 Gutas, Aristotelian Tradition, pp. 154-8.

86 S. Afnan, Avicenna, London: G. Allen \& Unwin, 1958. pp. 60-1. Gutas, Aristotelian Tradition, p. 145.

87 S. H. Nasr, Cosmological Doctrines, pp. 178-9.

88 Afnan, Avicenna, pp. 62-5.

89 Ibid., pp. 66-70.

90 H. Corbin, Avicenna and the Visionary Recitals, tr. by W. R. Trask, New York: Routledge \& Kegan Paul, 1960, p. 125.

91 Gutas, Aristotelian Tradition, p. 145.

92 Afnan, Avicenna, p. 75.

93 I. R. Netton, Allāh Transcendent, London: Routledge, 1989, p. 9.

94 Gutas, Aristotelian Tradition, p. 238.

95 Ibid., p. 141.

96 Ibid.

97 Ibid.

98 S. Inati, Ibn Sīnā and Mysticism, New York: Kegan Paul, 1996, pp. 69.

99 Ibn Sīnā, Risāla fì al-'Ishq, in jami' al-bad'i', Cairo, 1917.

100 S. Inati, Mysticism, pp. 78-9.

101 It seems to me that the events in this book were arranged according to al-Ghazālī's estimation of the importance to him of the different sciences. We will see throughout this chapter that theology, for al-Ghazālī, signifies a lower truth than either philosophy or Sufism and that the highest truth in his judgment is Sufism in conjunction with philosophy. See also M. W. Watt, Muslim Intellectual, Edinburgh: Edinburgh University Press, 1963, pp. 51-2.

102 Smith, al-Ghazālì, p. 15.

103 Ibid., p. 17.

104 Ibid., pp. 17-20.

105 G. F. Hourani, "A Revised Chronology of Ghazālīss Writings," Journal of American Oriental Society, 1984, 104, pp. 289-302.

106 Ibn Sīnā, Tahafut al-Falāsifa, Cairo: Ihyà̄' al-Kutub al-'Arabiyya, 1947, see its introduction.

107 G. F. Hourani, “Ghazālī’s Writings,” pp. 289-302.

108 There are many parallel passages in Ibya $\vec{a}$ and $M \bar{\imath} z \bar{a} n$. We can see the whole of 'A ja' 'ib al-Qalb in the first book of the third volume of $I b y \vec{a}$ ' in Mizzann, pp. 217-30 and 331-40. Lazarus-Yafeh in Studies in al-Ghazzāl $\bar{\imath}$ points this out and presents two similar passages, p. 311; H. Lazarus-Yafeh, Studies in al-Ghazzālā, Jerusalem: Magnes Press, 1975. 
109 See Tāj al-Dīn Ibn Nasr al-Subkī, Țabaqāt al-Shāfíiyya, Cairo: Maṭba'at 'Isa al-Bābī al-Halabī, no date, Vol. 6, p. 199; and also Șalah al-Dīn Ibn Ibak al-Ṣafadī, al-Wāfi Bayn al-Wafyyāt, Istanbul: Matba 'at al-Dawla, 1931, Vol. 1, p. $27 \dot{5}$.

110 Chidiac, Robert, ed. and trans., Al-Ghazālī's Réfutation excellente de la divinité de Jésus-Christ d'après les Évangiles, Paris, 1939.

111 Lazarus-Yafeh, Studies, pp. 460-2.

112 If we compare Ghazālî̀'s crisis with that of al-Ash'arī who turned to the opposite side and justified this crisis in all his later works, we can see that Ghazāli did not undergo a mental crisis but struggled with the difficult decision to turn his face fully towards Sufism. See also McCarthy, Freedom and Fulfilment, pp. 90-3.

113 Lazarus-Yafeh, Studies, pp 299-300.

114 Abū Hāmid al-Ghazālī, Iḅy $\bar{a}$ ' 'Ulūm al-D̄̄n, Cairo: al-Mujalad al-'Arab̄̄, 1998a, Vol. 4, pp. 108-10, 297, 367, 386.

115 G. F. Hourani, “A Revised Chronology,” pp. 289-302.

116 Ibid.

117 Smith, al-Ghazāl̄̄, p. 35.

118 Lazarus-Yafeh, Studies, pp. 249-59.

119 Smith, al-Ghazālā, pp. 105-33.

120 Rahman, Prophecy in Islam: Philosophy and Orthodoxy, London: Allen \& Unwin, 1958, pp. 94-8. In addition, there is a section on al-Ghazālī in Zaehner's work Hindu and Islamic Mysticism which is based on his inauthentic work al-Risala al-Laduniyya. See R. C. Zaehner, Hindu and Muslim Mysticism, London: Oneworld, 1960.

121 Ibn Sīnā, Mìzān-al-'Amal, ed. S. Donia, Cairo: Dār al-Ma‘āiif, 1965, p. 331.

122 Lazarus-Yafeh, Studies, pp. 254, 308.

123 G. F. Hourani, “A Revised Chronology,” pp. 289-302.

124 M. Campanini, "Al-Ghazālī," in S. H. Nasr, History of Islamic Philosophy, London and New York: Routledge, 1996, pp. 261-2.

125 Al-Ghazālī, Ibyā', Vol. 1 (Introduction), pp. 12-13.

126 Gairdner, W. H., "Ghazālìs Mishkāt al-Anwār and the Ghazālī problem," in Der Islam, 1914, 5, pp. 121-53.

127 M. W. Watt, "A forgery in Ghazālīs Mishkāt," Journal of the Royal Asiatic Society of Great Britain and Ireland, 1949, pp 5-22.

128 Al-Ghazālī, The Niche of Light, ed. D. Buchman, Provo, UT: Brigham Young University Press, 1998c, p. 27.

129 Abū al-Hasan al-Ash'arī, Maqālāt al-Islāmiyȳ̄n, ed. Muhy al-Din Abd al-Hamid, Beirut: Dār al-Mashriq, 1990, pp. 247-50.

130 Ibid., p. 247.

131 Ibid., pp. 247-8.

132 Ibid., p. 249.

133 Ibid.

134 Ibid., p. 249.

135 Ibid., p. 248.

136 Ibid., p. 250.

137 B. Abrahamov, Divine Love in Islamic Mysticism, London and New York: Routledge, 2003.

138 Ibid., pp. 1-3.

139 Ibid., p. 3.

140 Ibid., pp. 4-5.

141 Ibid., pp. 14-16.

142 Ibid., pp. 27-33.

143 Ibid., pp. 17-25. 
144 M. Fakhry, A History of Islamic Philosophy, 2nd edn, London: Longman, 1983. p. 237.

145 Zaehner, Hindu, p. 146.

146 Ibid., p. 139. Zaehner explains that the unity of God for al-Junayd means the separation of the contingent (soul) from the eternal (God). He considers this idea to be influenced by the dualistic idea of God in Indian mysticism.

147 Ibid., p. 140, see Fakhry, History, pp. 237-8.

148 Zaehner, Hindu, p. 141.

149 Ibid., p. 149.

150 Ibid., p. 148.

151 This kind of mysticism was based on the Hadīth, which al-Ghazālī also mentions in Mishkāt: "when my servant draws ever near to me by performing works of supererogation then do I begin to love him; and once I have started to love him, I become his ears by which he hears and his eyes by which he sees."

152 Fakhry, History, p. 243.

153 Ibid. Fakhry explains that al-Bistāmī was influenced by his Indian master, a converted mystic called Abū 'Alī al-Sindī, who taught him the doctrine of "annihilation in unity."

154 Zaehner, Hindu, p. 112. Some Sufis report a vision of him where he ascends to the heavens and searches for God and when he reaches the "throne," he finds it empty and asks 'Master, where shall I seek thee?' And the veils were lifted up and he 'saw that I am I, yea I am I. I turned back into what I sought and it was I.' Fakhry, History, p. 244.

155 Fakhry, History, p. 245. We observe, however, here that all of them agree that union and indwelling can happen and has happened, but none of them explains how it actually takes place. Al-Hallāj and al-Bisțāmī report only what they experienced and Zaehner notes that al-Bistāmī at the end of his life was not sure of the authenticity of his experience. Zaehner, Hindu, p. 117.

\section{2 'Abd al-Jabbār's view of the relationship with God through divine assistance, lutf}

1 Abū Manșūr al-Māturīī̄, Kitāb al-Tawhìd, ed. F. Khulayf, Alexandria: Dār al-Jami'āt al-Mașriyya, n.d., pp. 49-57.

2 A. Dhanani, The Physical Theory of Kalam: Atoms, Space, and Void in Basrian Mu'tazili Cosmology, Leiden: Brill, 1994, pp. 38-9; A. 'Uthman, Sharh al-Ușūl al-Khamsa, Cairo: Maktabat Wahba, 1996, pp. 104-7. See also Al-Ash'arī, Maqālāt al-Islāmiyyīn (Die dogmatischen Lebren der Anbänger des Islams), ed. H. Ritter, Wiesbaden: F. Steiner, 1980, p. 304.

3 Some groups wished to relate the use of the word accident, a'rād, to the Qur'an but Ja'far Ibn Harb (from the Baghdādī Mu'tazilites) argued against this tendency and considered the use of this word to be a matter of pure convention, which cannot be proven. But according to al-Ash'arī all groups agreed that accidents in general do not have a substantial existence and they only subsist in bodies, with the exception of the accident of time and the accidents which describe God's active attributes; al-Ash'arī, Maqālāt, pp. 369-70. Al-Nažāām considers, as Dhanani explains, that accidents cannot exist outside the atom and atoms exist only in space. Abu al-Hudhayl, in contrast, considers that some accidents exist outside atoms, such as the accident of "time" and the accidents attributed to God's actions, which exist in no place, as shown below. See A. Dhanani, Physical Theory p. 39. 
4 Some accidents, however, are permanent; these can be called essential accidents. They cause the essential attribute of each being. An essential attribute is the attribute which conveys the quality through which the thing or the being becomes itself: a human has the essential attribute of humanity, or a tree has the essential attribute of being a tree. See Dhanani, Physical Theory, p. 34. This attribute which Frank also calls the attribute of the essence is the ground on which the thing can have its other attributes. All other attributes are conditioned with the existence of the thing but the attribute of the essence conveys the essence of the being even if it does not exist, such as that humanity is human whether a specifically attributed human exists or not. It is the attribute which makes a thing belong to its genus. R. M. Frank, Beings and Their Attributes: The Teaching of the Basrian School of the Mu'tazila in the Classical Period, Albany, NY: State University of New York Press, 1978.

5 Dhanani, Physical Theory, pp. 33-4.

6 'Abd al-Jabbār, Al-Majmī' fī al-Mubīt bi-al-Taklīf, ed. Sayd 'Azmī, Cairo: al-Dār al-Mașriyya li-ta'liff wa al-Nashr, n.d., p. 172.

7 Ibid., pp. 172, 177-8.

8 Ibid., pp. 180-3. 'Abd al-Jabbār argues at length against the Ash'arite concept of the eternal attributes which define God eternally. He explains that, if accidents are eternal, then they have their existence within themselves and consequently they stand beside God in eternity. His main argument, however, is that the divine attributes do not belong to God through an accident or a cause, ma'n $\bar{a}$, neither created nor eternal, but rather form the essence of God because accidents, $m a^{\prime} \bar{a} n i$, exist either in bodies or in no place and they can only be created.

9 'Abd al-Jabbār, Muhīt, pp. 166-7. It seems also that 'Abd al-Jabbār did not follow the concept of the aḅwăl states of Abū Hāshim. Badawi explains that this is because the states in what God "has in Himself" differ from what 'Abd al-Jabbār and Abū 'Alī al-Jubbā'̄ term "li-nafsibi." This last phrase does not describe what God has in Himself and shows that God acts simply through His essence (A. Badawī, Madhābib al-Islāmīyyin, Beirut: Dār al-'Ilmlil-Malāyyin, 1983 , p. 412). The states which God has in himself must, for Abū Hāshim, be different. It seems to me that these states are like Abū al-Hudhayl's concept that God knows by a knowledge which is Himself; this mainly denotes a distinction of the different attributes in the essence of God.

10 'Abd al-Jabbār, al-Muß̄t, pp. 107-8, 'Abd al-Jabbār explains in great detail here the omnipotence of God which includes all that comes under ability and shows that this is the real meaning of God's being able in Himself and not through an ability which He possesses. He goes on to say the same about His omniscience and explains that there is nothing which God does not know about all that happens in the future, the past and the present; however, he knows this through a knowledge which He knows through Himself (ibid., p. 119). This idea is similar to al-Ghazâlī's proof that God knows the particular in time through His eternal knowledge which is one and includes knowledge of all that can be known; see Chapter 4, sub-section titled "God: the creator of the world" under section titled "The features of God according to al-Ghazālī."

11 J. R. T. M. Peters, God's Created Speech A study in Speculative Theology of the Mu'tazilī Qādī al-Quḍāt Abū al-Ḥasan 'Abd al-Jabbār Ibn Aḥmad al-Hamdhān̄̄, Leiden: Brill, 1976, p. 29. Peters explains that 'Abd al-Jabbār demonstrated this concept under the heading of al-Mughni 5 . When he had finished discussing all the issues which are related to tawbid, he declared, "The treatise on tawhid is finished; there follows the treatise on 'adl." But Peters points out that nowhere else in al-Mughnī did "Abd al-Jabbār note that he had 
finished the treaties on 'adl. (The Egyptian edition gives $A l-M u g h n \bar{\imath}$ the title al-Mughnī on Monotheism and Equity.) See also, 'Abd al-Jabbār, Abu al-Hașan, Al-Mughn̄i fì Abwāb al-Tawhīd wa al-'Adl, Cairo: Wizārat al-Thaqāfah wa-al-Irshād al-Qawmī, 1960-8, Vol. 5, p. 259.

12 Ibid., pp. 98-102. See also 'Abd al-Jabbār Sharh, pp. 151-6.

13 'Abd al-Jabbār, al-Mubīt, pp. 129-30.

14 Ibid., pp. 136-8.

15 Al-Ghazālī, al-Iqtișād fì al-İ'tiqūd, Cairo: al-Maṭba'a al-Mașriyya, 1902, pp. 86-7.

16 'Abd al-Jabbār, Sharh, pp. 205-11.

17 'Abd al-Jabbār, Physical Theory, p. 39.

18 'Abd al-Jabbār, Sharh, pp. 51-3, 64-6.

19 Al-Ash 'arī, Maqālāt, p. 304.

20 'Abd al-Jabbār, al-Muh̄it, pp. 35-45. In this section 'Abd al-Jabbār explains thoroughly the meaning of akwān, and proves its existence as a determinant $m a^{\prime} n \bar{a}$ which indicates movement and immobility in the bodies. After this he uses movement and immobility, which denote convergence and separation, to prove that the atoms come together to constitute a body because of the existence of these aspects $m a^{\prime} \bar{a} n i$ which come to inhere in them and cause the existence of a body. He explains this proof in a simpler manner in 'Abd al-Jabbār, Sharh, pp. 96-104.

21 'Abd al-Jabbār, al-Mub̄̄t, pp. 40-54. In a long chapter 'Abd al-Jabbār describes these four accidents akwān and explains how we are able to observe their function. Then he considers the meaning of "created" and "eternal" in order to prove that the accidents and the body must be created.

22 'Abd al-Jabbār, al-Mubīt, p. 36.

23 'Abd al-Jabbār devotes al-Mughnī, Vol. 6, Part 1 to a study of the basis for acts; it is also mentioned in Sharh, pp. 324-63 and the sixth chapter of al-Mubit t pp. 229-65.

24 'Abd al-Jabbār, al-Mub̄it, pp. 230-2.

25 'Abd al-Jabbār, al-Mubìt, p. 231.

26 G. F. Hourani, Islamic Rationalism, Oxford: Oxford University Press, 1971, p. 30. See also 'Abd al-Jabbār, Al-Mughnī, Vol. 6, Part 1, pp. 87-101.

27 'Abd al-Jabbār, Al-Mughnī, Vol. 6, Part 1, p. 177.

28 'Abd al-Jabbār, Sharh, pp. 326-7.

29 Ibid. See also 'Abd al-Jabbār, al-Muhīt, p. 231.

30 'Abd al-Jabbār, Al-Mughnī, Vol. 6, Part 1, pp. 7-8, and Hourani, Islamic Rationalism. p. 39.

31 Hourani, Rationalism, p. 127.

32 'Abd al-Jabbār, Al-Mughn̄̄, Vol. 11, pp. 58-60.

33 Ibid., p. 68.

34 Ibid., p. 68.

35 Ibid., pp. 64-7, 86.

36 Ibid., p. 81.

37 Both God's gracious acts, however, are closely attached to God's will because God as a self-sufficient ghanayy by His nature does not need the world. His creation and the gift of His guidance are pure grace and therefore must have been given according to a divine will. God must be "willing" in 'Abd al-Jabbār's theology because whoever performs an act either wills it or is obliged to do it. The main difficulty with this attribute is that some theologians and philosophers consider that "will" causes a change in the essence of God, since He would have willed after not willing. In al-Mubīt 'Abd al-Jabbār explains that change means things being transformed through an attribute or an accident into others to 
cause a new state, such as the transformation of black into white. But if a thing gets a new attribute which it lacked before then this should not be regarded as change because nothing has changed, but instead a new attribute has been gained. When someone wills to do something which he has never done before then he has not undergone change, but if his will comes after being not willing, then we can trace a change. Therefore, 'Abd al-Jabbār explains that there is no evidence that God wills after being not willing or disliking; He rather wills some things and does not will others. Consequently, His will does not denote a change in Him and, 'Abd Jabbār continues, if we were to consider that God's will caused a change, then we would have to regard all His acts as also causing change in Him because all His acts happened after His not acting. The main theological problem with this attribute, however, is that God's will is not, for 'Abd al-Jabbār, an essential attribute which He has in Himself but it is rather enabled to act through a created will. Created will means here a temporal will which only relates to a certain act and is not a part of God's essence. This was his main contention against the Ash'arites, who considered it an eternal attribute. If will is an eternal attribute, 'Abd al-Jabbār argues, then God must will all that can be willed without any limitation, because an eternal attribute includes all possibilities, as explained above. But since there are things in the world which God cannot have wished, for example, all disobedience, evil acts and other worlds which do not exist, then God evidently wills some things and not others. The disagreement about this attribute is related to the problem of the divine decree, which was the main conflict between the Ash'arites (followers of al-Ash'arī, who once was a Mu'tazili master and then rejected Mu'tazilism and established a traditional school of his own) and the Mu'tazilites. For the Mu'tazilites, humans are responsible for all their acts and what these acts generate; the Ash'arites, conversely, believe that the only creator is God and He creates all human acts. Humans, in their view, are enabled to act through an immediate ability which is provided to them at the time of the act. Thus, since God is to the Ash'arites the creator of all acts and events, His will is unlimited and therefore eternal. The Mu'tazilites seem, however, to have supported their argument against the concept of the divine decree through the concept of the temporal will of God, demonstrating the distinction between what God wills and what He dislikes and forbids. See 'Abd al-Jabbār, al-Muhīt, pp. 246-50.

38 'Abd al-Jabbār, Al-Mughnī, Vol. 13, p. 4.

39 'Abd al-Jabbār, Al-Mughnī, Vol. 14, p. 24.

40 Ibid., p. 53.

41 Al-Ghazālī, al-Iqtișād, pp. 121-3.

42 Al-Asha'rī says that Abū al-Hudhayl and Mu'ammer seem to regard the substance jawhar as the atom because they consider it to be not further divisible and therefore a single substance which cannot be a body but forms one atom of a body. Abū 'Alī al-Jubbā'̄̄ also follows this theory (Ash'arī, Maqālāt, p. 307). But since 'Abd al-Jabbār refers to the body as a jawhar then we can conclude that he considers the jawhar to consist of more than one atom. See Peters, Created Speech, pp. 121, 122. See also Dhanani, Physical Theory, pp. 55-7. Badawi considers that Abu al-Hudhayl was one of the earliest to adopt the theory of atoms and accidents and was influenced probably by the ancient Greek atomists who, however, consider that the smallest part of the body, the atom, is immortal. They also consider that movement, convergence, warmth, coldness, form and all other attributes do not belong to atoms but come to inhere in 
them. Badawi mentions here also the possibility that Abū al-Hudhayl could have got his information about the theory of atoms from the Indians who were living in Basra, which was an international port at the time, because the Indian school Vishka also adopted this theory. However, he inclines more to the view that Abū al-Hudhayl probably knew the theory of atoms from the translation of Greek books which was going on at this time. Badawi, Madhdāhib, pp. 183-4.

43 Peters, Created Speech, pp. 119-21. Peters considers that the term 'substance' has a metaphysical rather than a physical meaning. It suggests independent existence which denotes permanence and shows the ability to exhibit other qualities. It is used for the atom in its productive form.

44 Ibid., pp. 123-5.

45 Ibid., p. 125.

46 'Abd al-Jabbār, Al-Mughn̄̄, Vol. 11, pp. 304-5.

47 Ibid., pp. 310-11.

48 His opponents explain that the reason for the identification between the activity of the soul and of the body is that the soul inheres in all parts of the body and initiates its activities. But 'Abd al-Jabbār explains that if living is a substance in a person which is able to know and perceive, then it should be more likely that it could know the reality of the person's bodily structure and organs, which is the nearest to the internal living soul; yet we know that no one has the ability to see or describe his own bodily organs.

49 Another proof presented here by 'Abd al-Jabbār is that if the soul is a separate substance which has its own knowledge, power and perception, then it can see and hear things in the case of defects in its organs, but we know that the blind cannot see and the deaf cannot hear. It is also clear that each sense-organ is responsible for one kind of perception, but if the soul in the body had perception not through an accident but within itself then it would be possible to use one organ for several kinds of perception, which to 'Abd al-Jabbār is absurd. See Al-Mughnī, Vol. 11, pp. 339-41.

50 'Abd al-Jabbār, Al-Mughnī, Vol. 11, pp. 387-90.

51 Ibid., pp. 371-87.

52 Hourani's translation, see Hourani, Rationalism, p. 17. See also, Al-Mughnī, Vol. 12, pp. 13, 25.

53 'Abd al-Jabbār, Sharh, pp. 45-9.

54 Ibid., pp. 48-53.

55 Daruri is usually translated as "necessary" but Hourani explains that "necessary" in philosophical English means "logically implied," which denotes discursive knowledge. See Rationalism, p. 20. However, the term "immediate" which Hourani suggests, does not, according to Peters, include prima facie ideas which are created from God and form a part of this kind of knowledge. See Peters, Created Speech, pp. 53-4.

56 'Abd al-Jabbār, Al-Mughnī, Vol. 12, pp. 61-4.

57 Here 'Abd al-Jabbār explains the idea of kamāl al-'aql which is one of the qualification of being mukallaf. He says that al-'aql is certain reliable knowledge which a person has without use of the senses or acquired knowledge. The word 'aql comes from $y u^{\prime}$ 'qil al-nāqa, which means to hinder the camel from moving. It is used here metaphorically, 'Abd al-Jabbār explains, and refers to knowledge which is basic and does not change, like the basic knowledge of ethical rules or the knowledge of basic general rules which are always true. Al-Mughnī, Vol. 11, pp. 379-80, 386. See also Peters, God's Created Speech, p. 83.

58 'Abd al-Jabbār, Al-Mughnī, Vol. 11, p. 375. 
59 'Abd al-Jabbār, Al-Mughnī, Vol. 11, p. 376-7.

60 Ibid., p. 379.

61 Ibid., pp. 379-87.

62 Ibid., p. 384.

63 This idea is best explained by C. D. Ross:

an act, qua fulfilling a promise... is prima facie right, is self-evident; not in that it is evident from the beginning of our lives, or as soon as we attend to the proposition for the first time, but in the sense that when we have reached sufficient mental maturity and have given sufficient attention to the proposition, it is evident without any need of proof, or of evidence beyond itself.

(quoted in Hourani, Rationalism, p. 22)

See also C. D. Ross, The Right and the Good, Oxford: Clarendon Press, 1930, p. 29.

64 Peters, Created Speech, p. 55.

65 Hourani, Rationalism, pp. 22-3.

66 Ibid., p. 23.

67 'Abd al-Jabbār, Sharh, p. 39.

68 Ibid., pp. 88-9.

69 The use of the word "nazar" which means inquiry through reflection, depends on its Qur'ānic background. 'Abd al-Jabbār in his works on religion is concerned with the kind of reflection which leads to the knowledge of God, so he excludes reflection about worldly affairs, umur al-dunya, and concentrates his efforts on the sort of reflection which concerns religious matters, Sharh, pp. 44-5.

70 This explanation here reminds us of Aristotle's explanation of the two states of the intellect: the potential and the intellect in babitu in which Aristotle explains that the process of knowledge transfers the intellect from the state of being and not thinking, potential, to the state of having knowledge. See Chapter 2, sub-section titled "The main features of the responsible person, al-Mukallaf" under the section "Human nature and the different ways of knowledge."

71 'Abd al-Jabbār, Al-Mughn̄, Vol. 12, pp. 16-18.

72 'Abd al-Jabbār, Sharh, p. 87.

73 Peters, Created Speech, pp. 66-9. 'Abd al-Jabbār gives five conditions for reaching results through reflection, which Peters summarizes as follows:

First the reflecting subject has to be compos mentis ('aqqil). Second there must be a connection with an indication (indicated object), third the reflecting subject must know this indication; fourth the reflecting subject does not know the thing indicated before, nor must he be in positive ignorance based on sophism about it, but there must be some form of uncertainty; fifth, the reflected subject has to follow the way indicated by the indication, just as it has been meant by the one who placed it as an indication.

If all these conditions are fulfilled and the tranquillity of the soul is present then the reflection must generate knowledge. Ibid., p. 60.

74 Indications for 'Abd al-Jabbār are of four kinds: indication which is based on necessary knowledge, reflection on the Qur'ān, the sayings of the prophet Sunna and the consensus of the first believing community Ijmā'. See 'Abd al-Jabbār, Sharh, p. 88. Thus we reflect either on an indication which is known to us necessarily or on revealed information which indicates knowledge about God. However, 'Abd alJabbār also uses dalīl in a wider sense to mean "proof." Hourani explains that proof for 'Abd al-Jabbār means linking the thing to be proved to something apprehended through immediate knowledge (in the way that it is used in a syllogism). 
This proof must lead to a single conclusion which is dependent on the necessary premise: "the inquiry of all thinkers about the proof of one thing occurs in one way, so it must be that what is produced from it does not vary, it must produce the like for all of them." Here, "Abd al-Jabbār is declaring that rational inquiry must depend on objective reflection which is linked to a necessary apprehended premise. Hourani presents the following objection from some critics:

one who disagrees with us may have the same rational capacity as we and make just as much effort, but fail to attain knowledge (or the same knowledge), and this proves that inquiry by method of proof does not necessarily produce knowledge.

'Abd al-Jabbār, however, relates the failure in such cases not to the method of research but to the objectivity of the person who uses the method. The failure here depends on a desire to support previous erroneous belief "either on account of tradition or convention or growing up in it or for ambition, or to obtain benefit or repel harm." See al-Mughni, Vol. 12 p. 125.

75 "Abd al-Jabbār, Sharh, pp. 46-8.

76 Ibid.

77 Ibid.

78 Hourani, Rationalism, p. 18.

79 'Abd al-Jabbār, Al-Mughnī, Vol. 12, p. 34.

80 Ibid., p. 54.

81 Hourani, Rationalism, p. 47, see also, Al-Mughn̄, Vol. 12, p. 21.

82 In the first five volumes he discusses the different proofs of the existence and unity of God with His essential attributes. Volumes 6 and 7 elucidate the two actual attributes of God sifät al-fi'l willing and speaking. In Volumes 8, 9, and 10 'Abd al-Jabbār explains the attributes of human beings and their abilities. Volume 11 discusses rational taklif $f$ and Volume 12 discusses the ways in which we obtain knowledge. Volume 13 discusses how God assists human beings to discover and understand his taklif $f$ and Volume 14 discusses the idea of al-așlab and the basis of repentance.

83 'Abd al-Jabbār, Sharh, p. 531.

84 Ibid., pp. 531-2.

85 It seems to us here that what 'Abd al-Jabbār is explaining is as follows: if the Qur'ān were the eternal knowledge of God, which is what the concept of the eternity of the Qur'ann actually means, then it would be an explanation of all that God knows about the world, its physical, mathematical and metaphysical context, and it would not be a revelation of His specific will for human beings. But since the Qur'ān is mainly devoted to revealing commands and prohibitions, then it discloses only a part of God's knowledge and cannot be an expression of His eternal knowledge. This in fact emphasizes the conceptual simplicity of the eternity of the Qur'ān.

$86 \mathrm{He}$ discusses the importance of revealed knowledge under his main discussion of prophecy in al-Mughni, Vol. 15. Here he compiles evidence to support the view that sending prophets is acceptable to reason and that their messages benefit the prophets themselves and those to whom they are sent. His argument is directed against the Barāhima, an Indian group who did not believe that God sent prophets. Their view was that if God sent prophets with messages which were not rationally acceptable, they would be useless because our minds could not accept them, and if the messages were attainable by rational knowledge there would be no need to send them. 'Abd al-Jabbār, Al-Mughnī, Vol. 15, p. 24. 
87 'Abd al-Jabbār, Al-Mughn̄̄, Vol. 15, p. 24.

88 Ibid., p. 26.

89 Ibid., pp. 30-6.

90 Hourani, Rationalism, p. 132. An objection raised here by 'Abd al-Jabbār's opponents is why these motivating revealed laws should be obligatory. "Abd al Jabbār replies that, when a certain act is assisting the performance of another in such a way that the second can only be carried out when the first is performed, then both must be regarded as duty because performing the obligation depends on both of them. See 'Abd al-Jabbār, Al-Mughnī, Vol. 15, pp. 36-9.

91 Hourani, Rationalism, p. 136.

92 One of God's 99 beautiful names.

93 Abdal-Jabbār, Sharh, p. 520, translation by B. Abrahamov, “ 'Abd al-Jabbār's Theory of Divine Assistance (Lutf)," Jerusalem Studies in Arabic and Islam, 1993a, p. 50.

94 Ibid. Abrahamov, "Divine Assistance," p. 50.

95 "Abd al-Jabbār, Al-Mughnī, Vol. 13, p. 160.

96 Ibid., p. 7.

97 Although 'Abd al-Jabbār and the Bașrians did accept that God grants the best possible al-aslah, as we see from the discussion above, they disagree on some vital points in this concept with a group which he refers to as the Aṣhāb alAșlah. Al-Ash 'arī also refers to this group, but does not mention its name. But he presents their ideas under the Mu'tazalites. See al-Ash'arī, Maqālāt, p. 250. Probably this group comprised the followers of al-Nazzam because he was the first to present this concept. See 'Abd al-Qāhir al-Baghdādī, Al-Farq Bayn al-Firaq, Cairo: Dār al-Turāth, n.d., p. 115.

98 'Abd al-Jabbār, Al-Mughnī, Vol. 14, p. 23.

99 Ibid., p. 22.

100 Ibid., p. 53.

101 Ibid., p. 9.

102 'Abd al-Jabār, Al-Mughnī, Vol. 13, pp. 5-9. However, there is a case where God compels believers to choose good and constrains the knowledge of the obligatory for them, without any effort on their part. This will be the situation of the believers in paradise, 'Abd al-Jabbār explains, in Al-Mughnī, Vol. 14, p. 126.

103 'Abd al-Jabbār, Al-Mughn̄̄, Vol. 13, p. 97.

104 Ibid., p. 47.

105 Ash'arite theologians who believe that all human acts come from God believe also that God guides humans to evil as well as to good. His guidance is in accordance with $\mathrm{His}$ eternal knowledge of each human and therefore $\mathrm{He}$ guides unbelievers to evil in order to punish them. See Baqillān̄i, al-Tambīd, ed. R. J. McCarthy, Beirut: al-Mațba'ah al-Kāthūlikiya, 1957, pp. 338-40.

106 'Abd al-Jabbār, Al-Mughn̄, Vol. 13, pp. 23-5.

107 Ibid., pp. 65-6.

108 Abrahamov, "Divine assistance," p. 48.

109 'Abd al-Jabbār, Al-Mughn̄, Vol. 11, pp. 46-8.

110 Ibid., Al-Mughnī, Vol. 13, p. 153.

111 Ibid., pp. 84-5.

112 Ibid., Al-Mughnī, Vol. 12, p. 347.

113 Ibid., pp. 352-6.

114 Ibid., pp. 409-11.

115 Ibid., pp. 404-9.

116 Ibid., p. 409.

117 Ibid., p. 433. 
118 Ibid., p. 403.

119 Ibid., p. 411.

120 Ibid.

121 See his criticism of this group in Sharh, p. 67.

122 He devotes about 40 pages to this under the heading "ithbāt al-alām," the proofs of pain. His discussion is not easy to follow but in general he is arguing here against the groups who consider that pain is not perceivable but it is known only by necessity. In this case it is not easy or even possible to identify a certain pain and distinguish between different pains, especially for someone who is in poor health. These groups also consider that pain could not be either sent from God or man but is simply the absence of good health intifä' al-siba. See 'Abd al-Jabbār, Al-Mughnī, pp. 229-71.

123 Ibid. 'Abd al-Jabbār discusses this point in great detail, maybe because he thinks it is important to be able to distinguish between the different kinds of pain in order to be able to acknowledge the reasons for a specific pain, whether caused by a human or by God.

124 'Abd al-Jabbār, Mughn̄i, Vol. 13, pp. 272-6.

$125 \mathrm{H}$. Ritter considers that this group is Abl al-Thanawiyya, see al-Ash'arī, Maqālāt, p. 671. It is mentioned by al-Ash'arī in Maqālāt as the group which believes that the two sources of the world are light and darkness, ibid., p. 308

126 This was most probably the strongest view, for later on he devotes a separate section to the topic "pain is not evil because it is pain as the Thanawiyya believe." His main aim is to prove that there are kinds of pain which should not come under the heading of evil. See Al-Mughnī, Vol. 13, pp. 279-92.

127 Ibid., p. 279.

128 'Abd al-Jabbār, Al-Mughnī, Vol. 13, p. 279. But Aṣhāb al-Tanāsukh (probably al-Barahima) consider that pain and suffering are good when they are deserved. The Mujabbira group believed that if suffering and pain are caused by humankind then they are evil but if they are caused by God then they are good.

129 The word $z u l m$ is difficult to translate for it should not be limited to the Arabic philologist's narrow meaning of "unjust act," 'Abd al-Jabbār explains, because this would mainly describe the agent rather than the act. Hourani translates it as wrongdoing in order to include all kinds of wrong action though it does not express the strong connotations of $z u \mathrm{~lm}$. However, in this section we will use both words, $z u l m$ and wrongdoing, side by side. See Hourani, Rationalism, p. 50.

130 Hourani, Rationalism, p. 71. 'Abd al-Jabbār criticizes the philologists' understanding of zulm which is for them the opposite of ' $a d l$ justice, because it stresses mainly the $z \bar{a} l i m$, the one who performed the $z u l m$ rather than looking on the zulm as an objective act. See Al-Mughnī, Vol. 13, p. 299.

131 The knowledge that wrongdoing, zulm, is evil comes through our necessary knowledge, 'Abd al-Jabbār explains; thus, when we do $z u l m$ without any aspect of good in it we recognize it immediately to be evil and he asserts once more that the problem is not to identify zulm in general, mujmal, as evil, but to identify a particular action as zulm (Al-Mughni, Vol. 13, p. 301). He goes on to explain that wrongdoing, $z u l m$, is also evil whether it is intended or not, because the aspects of evil remain in both cases. See Al-Mughni, Vol. 13, pp. 308-9.

132 'Abd al-Jabbār, Al-Mughnī, Vol. 13, pp. 319-20.

133 Ibid., p. 335.

134 Ibid., p. 342.

135 Ibid., p. 346.

136 Ibid., p. 368.

137 Ibid., pp. 369-76. 
138 'Abd al-Jabbār, Al-Mughn̄, Vol. 13, pp. 377-81.

139 They tried also to raise the possibility that God causes pain for two reasons at the same time: because it is deserved and to confer benefit. But 'Abd al-Jabbār argues that if God causes pain for these two reasons then He must cause two different kinds of pain separately, one kind because it is deserved and the other for the sake of benefit. The main objection to the possibility, then, is that causing both at the same time would create confusion and the sufferer would not be able to distinguish the benefit from the punishment. See $A l-M u g h n \bar{\imath}$, Vol. 13, p. 378.

140 'Abd al-Jabbār, Al-Mughn̄, Vol. 13, p. 379.

141 Ibid., pp. 377-86, 405-8.

142 Ibid., pp. 405-30.

143 Ibid., pp. 387-8.

144 'Abd al-Jabbār, Al-Mughnī, Vol. 13, p. 391. An objection is raised here to the idea of comparing compensation and reward: as the takli $f$ was given in order to reward people, so pain is also given, in order to have both compensation and reward. 'Abd al-Jabbār devotes a long discussion to this problem but the important point for him is that reward is given to those who obey the takli f and this is in itself a good thing because taklif $f$ benefits the life of those who obey it and guides them to good acts; in this sense, rewarding is a praiseworthy action in response to the obedience of these people. But compensation is not a praiseworthy response to the bearing of pain; for pain is something which people have to accept. See $A l-M u g h n \bar{\imath}$, Vol. 13, pp. 392-5. Another possibility is raised here: to consider that pain is only caused for the sake of its compensation. Is it possible to consider that pain, with its compensation, is a gracious act of God like takli f because it means rewarding someone who does not deserve to be rewarded in the form of compensation for the pain which he has had to bear. 'Abd al-Jabbār answers this with a question: if God wanted to act graciously would he choose to give pain? (Can there be a better example of uselessness, 'abath, than that? he comments.) This to his mind, is just like someone pouring the water of one river into another as a way of helping another person. See $A l-M u g h n \bar{\imath}$, Vol. 13, p. 395.

\section{Relationship with God through knowledge and love, 'ishq, in the philosophy of Ibn Sinnā}

1 D. Gutas, Avicenna and the Aristotelian Tradition, Leiden: Brill, 1988, pp. 123-4, 145.

2 Ibid., p. 115.

3 Ibid., pp. 52-3. See also p. 115.

4 Ibid., p. 45. The introduction of the term "Eastern Philosophy" is in Gutas, Aristotelian Tradition, pp. 44-9.

5 Ibid.

6 Gutas, Aristotelian Tradition, p. 47.

7 Ibid., p. 47.

8 Ibid., p. 48.

9 Ibid., p. 130. See Note no. 28. Gutas gives the main western scholarship on this problem.

10 Ibid., pp. 129-30.

$11 \mathrm{H}$. Corbin, Avicenna and the Visionary Recitals, trans. W. R. Trask, London: Routledge \& Kegan Paul, 1960, p. 43.

12 S. H. Nasr, An Introduction to Islamic Cosmological Doctrines: Conceptions of Nature and Methods Used for its Study by Ikbwān al-Șafä, al-Birūn̄i and Ibn Sinnā, Cambridge, MA: Harvard University Press, 1964, pp. 187-8. 
13 Gutas, Aristotelian Tradition, pp. 115-17.

14 Ibid., p. 115.

15 Ibid., p. 116.

16 Ibid., p. 128.

17 Ibid., pp. 190-1.

18 Morewedge, "The Logic of Emanation and Sufism in the Philosophy of Ibn Sīnā," Journal of the American Oriental Society, 1971, 1, pp. 467-76; 2, pp. 1-18.

19 Ibid., pp. 469-70.

20 J. J. Houben, "Ibn Sīnā and Mysticism," in Avicenna Commemoration Volume, Calcutta: Iran Society, 1956, pp. 205-21.

21 Morewedge, "Emanation and Sufism," p. 472.

22 H. Corbin, The Visionary, p. 43.

23 Morewedge, "Emanation and Sufism," p. 474.

24 H. A. Wolfson, "The Knowability and Describability of God in Plato and Aristotle," in Wolfson, Studies in the History of Philosophy and Religion, Harvard and Cambridge, MA: Harvard University Press, 1973e, p. 98.

25 Ibn Sīnā, Risāla fì al-Sa'āda, in Majmū 'at Rasā'il al-Shaykh al-Ra' '̄s, Hyderabad: Uthmaniyah Press, 1935b, p. 90.

26 Wolfson, "The Knowability of God," pp. 98-103.

27 Ibid., pp. 106-14. It seems here that the problem for Aristotle was a technical one, the risk of violating the unity of God, but it is not clear whether he wanted to define and know Him philosophically and whether the definitions which he gives to God exist really in Him. For instance, we say that God has knowledge, but does He really have knowledge in His essence or do we know that He has it only through His actions? This I think is what others after him struggled with.

28 H. A. Wolfson, "Philo Judaeus," in Wolfson, Studies in the History of Philosophy and Religion, Harvard and Cambridge, MA: Harvard University Press, 1973, pp. 60-71.

29 Ibid. However, rational knowledge, for Philo, was not the only way of knowing God; rather it is a way which prepares one to receive direct knowledge of God through spiritual vision. This vision, although it is considered higher than rational indirect knowledge, nevertheless still does not reveal the essence of God but only asserts His existence. Thus, the essence of God remains veiled from all humans; even when God spoke to Moses, or prophets like him, His essence remained unknowable.

30 H. A. Wolfson, "Albinus and Plotinus on the Divine Attributes," in Wolfson, Studies in the History of Philosophy and Religion, Harvard and Cambridge, MA: Harvard University Press, 1973a, pp. 115-31.

31 Ibid.

32 H. A. Wolfson, "Avicenna, al-Ghazzālē and Averroes on Divine Attributes," in Wolfson, Studies in the History of Philosophy and Religion, Harvard and Cambridge, MA: Harvard University Press, 1973b, pp. 145-53.

33 Ibid., p. 149. See also I. R. Netton, Allāh Transcendent, London and New York: Routledge, 1989, pp. 154-5.

34 Wolfson, "Avicenna and al-Ghazzālī," p. 153.

35 Ibn Sīnā, al-Najāt fi al-ḅikma al-Mantiqūya wa al-țabìnya wa al-Ilāhīya, ed. M. al-kurdi, Cairo, 1938, p. 251.

36 Netton, Allāh, p. 154.

37 Ibid., pp. 152-3. See also F. Rahman, "Essence and Existence in Ibn Sīnā: The Myth and Reality," Hamdard Islamicus, 1981, Vol. 4, no. 1, pp. 3-14.

38 Ibn Sīnā, Fì al-'Ishq, pp. 72-3. 
39 Ibn Sīnā, $F \bar{\imath}$ al-'Ishq, p. 72. Ibn Sīnā says, "therefore the existence of beings is either because of the love "ish $q$ which is in them or because their existence and their love are one and the same thing."

40 Ibid., pp. 70-1.

41 Ibid., p. 72.

42 Ibn Sīnā, Al-Risāla al-'Arshiyya, in Majmū'at al-Shaykh al-Ra'ı̄s, Hyderabad: Osmania Press, 1935a, pp. 16-17. And also Ibn Sīnā, Najāt, p. 184.

43 J. Janssens, "Creation and Emanation in Ibn Sīnā" Documenti e Studi sulla Tradizion Filosofica Medievale, 1997, 8, p. 462.

44 Netton, Allāh, p. 164.

45 All existent things are, for Aristotle, either a constituent of matter and form or pure Intellect. See A. Badawi, Aristū, Cairo: Maktabat al-Nahḍa al-Mașriyya, 1944 , p. 170.

46 Ibid., pp. 170-3.

47 Netton, Allāh, p. 168.

48 Ibid., p. 168.

49 Ibid.

50 Al-Fārābī, Arā' Abl al-Madāna al-Fāẹila, Beirut: al-Maṭba'a al-Kāthūlikiya, 1968, p. 61-2.

51 Ibid, p. 57.

52 Al-Fārābi describes the existence of the beings as they emanate from God in the following passage:

Being are many and with their plurality they are in ranks, from His essence, Jawhar, every existence emanates, whether perfect or inadequate, His essence is an essence through which all beings emanated and then are arranged in ranks, in which every being will obtain its portion of existence and its rank in it.

(Al-Fārābīi, Arā', p. 57)

53 Netton also shows that in the scheme of al-Fārābīs emanation he calls the first Intellect the second, al-thāni.

54 Ibn Sīnā, Najāt, pp. 224-5.

55 Ibid. p. 273. He says "the number of the Intellects is the same as the planets which belong to them and it was ten after the First."

56 Ibn Sīnā, Najāt, p. 277. However, this concept of the "possibility of existence" is mentioned in many of Ibn Sinnā's writings, which raises the question of what this thing might be which a thing has in itself and which does not exist. Does it mean that the potential existence of everything must be prior to its real existence? If so, how can potentiality play a role in the existence of things when it itself does not exist? It is possible to have two explanations here: either Ibn Sinna means that the possibility of existence is an idea in the mind of God expressing a divine plan of what should exist, or there is a parallel potentiality which existed always beside God but only became actual by the addition of the existence which emanated from God. In his section on the divine providence Ibn Sinā explains that evil is pure matter which does not exist but is always pure potential, showing that potentiality probably does have in his mind a kind of semi-existence. Therefore, it seems that Ibn Sīnā sought, by introducing the theory of the "necessary and the possible", to assert a kind of existence which is only possessed by God as the Real existence and which does not contain nor has ever had any potentiality, in contrast to the existence of the world which contains potentiality and therefore has some degree of deficiency. Here, Ibn Sīnā probably tends to accept Plato's theory of the Real divine ideas and the shadow of the world, in considering that the Real existence is the 
existence of God and the whole world has a borrowed existence, reflecting the Necessary Existent.

57 Ibn Sīnā, Najāt, p. 274.

58 Ibid. p. 275.

59 J. Jenssens, "Creation and Emanation," pp. 462-3.

60 Netton, Allāh, p. 169.

61 Ibn Sīnā, Najāt, p. 281.

62 Netton, Allāh, p. 169.

63 F. Rahman, "Essence and Existence," pp. 4-6. See also Najāt, p. 267. He says, "form is not enough for the existence of matter but the form is only a part of the cause."

64 D. Burrell, "Essence and Existence: Avicenna and Greek Philosophy," Mélanges de l'Institute Dominicain d' Etudes Orientales du Caire, 1986, 17, p. 60.

65 Ibid., p. 61.

66 Rahman in his article "Essence and Existence" is hinting that Ibn Sīnā, through the theory of the third element, was trying to combine theories of creation and emanation. This means that God emanates the First Intellect but through giving existence to each being (the third element) He in fact confers creation, in the sense of bringing everything into being.

67 Ibn Sīnā, Najāt, p. 247.

68 Ibid., p. 247.

69 M. Marmura, "Some Aspects of Ibn Sinnās Theory of God's Knowledge of the Particular," Journal of the American Oriental Society, 1982, 82, p. 307.

70 Ibid.

71 Netton, Allāh, pp. 161-2.

72 Ghazālī, Tahāfut al-Falāsifa, ed. M. Fakhri, Beirut: Dār al-Mashriq, 1990, pp. 164-74.

73 L. Goodman, Avicenna, New York and London: Routledge, 1992, p. 153.

74 Ibid., pp. 62-3.

75 A. Nader, al-Nafs-al-Basharīa 'ind Ibn Sīnā, Beirut: Dār al-Mashriq, 1968, pp. 54-6 (collection of some texts on the human soul from Najāt and Shif $\bar{a}$ ').

76 Ibn Sīnā, Najāt, pp. 168-70.

77 Ibid., pp. 170-1.

78 Ibid., p. 164.

79 Goodman, Avicenna, p. 146.

80 Ibid., p. 131.

81 Ibid., p. 147.

82 Wolfson, "Avicenna, al-Ghazālī," in Wolfson, Studies, p. 146.

83 H. A. Davidson, Al-fārābia, Avicenna and Averroes on Intellect, Oxford: Oxford University Press, 1992, pp. 9-10.

84 Ibid., p. 9.

85 Ibid., pp. 10-11.

86 Goodman, Avicenna, p. 145.

87 Al-Fārābī, Ara', p. 112.

88 Gutas, Aristotelian Tradition, pp. 169-71.

89 Ibid., p. 162.

90 S. C. Inati, Ibn S̄̄nā's Remarks and Admonitions, Part 1, Toronto: Pontifical Institute of Mediaeval Studies, 1984, p. 133.

91 F. Rahman, Avicenna's Psychology An English Translation of Kitāb al-najāt, Book II, Chapter VI, with Historico-Philosophical Notes and Textual Improvements on the Cairo Edition Oxford: Oxford University Press, 1952, pp. 24-7.

92 Goodman, Avicenna, p. 140. 
93 F. Rahman, Avicenna's De Anima (al-Shifä'), London: Oxford University Press, 1959, pp. 244-7.

94 Rahman, De Anima, pp. 246-7.

95 F. Rahman, Prophecy in Islam: Philosophy and Orthodoxy, London: Allen \& Unwin, 1958, pp. 31-7.

96 Ibn Sīnā, Najāt, pp. 273-5.

97 Corbin, The Visionary, p. 73.

98 Ibid., p. 74.

99 Ibn Sīnā, Najāt, pp. 300-1.

100 Rahman, De Anima, p. 239.

101 Ibn Sīnā explains: when someone asks a person a question about what he has learned so far, the person will know at once that he knows the answer to this question and that he is absolutely able to give a full answer. This assurance comes from the fact that his knowledge is orderly and organized and is presented in steps and as the respondent is doing this he is also learning and creating his knowledge in the order he wishes.

Rahman explains that this situation discloses two stages: the first is the stage of certainty and assurance of the presence of the knowledge required in the mind, though not actually, for he has not yet formulated it. The second stage is arranging this knowledge in sequential steps. The assurance that the person feels does not rest in the presupposition that the knowledge required is close to potential in the mind, Ibn Sīnā explains, but rather that the knowledge is already present in the mind, which makes the person sure that he possesses the answer. Therefore, this knowledge is already known to him in a simple manner, that is, in a unified form but not in orderly, sequential steps. Therefore, we have here two kinds of knowledge: the simple unified form which prophets or scientists get from the divine world and the orderly kind of humanly created discursive knowledge. Rahman, De Anima, p. 243. However, Rahman considers that this kind of creativity, from the simple unified knowledge to discursive knowledge, is in Ibn Sinā's philosophy reserved for prophets, although in this example there is no evidence for saying so. Rahman, Prophecy, pp. 33-5.

102 M. Marmura, Ibn Sìnā fì Ithbāt al-Nubbuwwāt, Beirut: Dār al-Mashriq, 1968, p. 48.

103 Ibn Sīnā, Najāt, pp. 284-6.

104 J. Janssens, "The Problem of Human Freedom in Ibn Sīnā," Patronat d'Estudis Osonencs, 1996 (Sèrie "Actes," 1), pp. 112-13.

105 Ibid., p. 114. Janssens discusses also the problem of whether the theoretical intellect, in the view of Ibn Sinnā, can provide guidance for human behaviour. He explains that since theoretical knowledge for Ibn Sīnā provides only universal knowledge then it cannot provide detailed guidance for human behaviour but only guidance about what is theoretically good or evil. He believes that for Ibn Sinā practical knowledge, since it is concerned with contingent human behaviour, does not come within the sphere of philosophy, which is mainly interested in eternal concepts. Thus, since eternal concepts are known to humanity through the help of the Active Intellect, human, practical, contingent knowledge is guided through revelation. Therefore, providing divine law is a part of God's providence, which is needed to preserve good order.

106 Ibn Sīnā says:

It is not possible that the first providence requires these benefits (the benefits which humanity has by creation) and does not require that (sending messages and divine law) which is its basis; and it is not possible that the First Principle and the angels after Him know this and do not know that... how 
it is possible that (the divine law) does not exist if what is related to it and built upon it, exist? Therefore the existence of a prophet is necessary wäjib and it is necessary that he is a human and necessary that he would have certain special gifts above all other humans.

(Ibn Sīnā, Najāt, p. 304)

107 Nader, al-Nafs, pp. 62-3.

108 Gutas, Aristotelian Tradition, p. 25.

109 Ibn Sīnā, Risāla fì Māhiyyat al-Ṣalāt, in Jāmi' al-Badā'’’', ed. M. al-Kurdi, Cairo, 1917 a, p. 9.

110 Ibid., pp. 11-12.

111 Ibid., pp. 12-13.

112 Ibid., p. 8.

113 Ibid., p. 9-12.

114 Gutas, Aristotelian Tradition, p. 181.

115 Rahman, Prophecy, p. 74. Rahman considers here that Ibn Sīnā's explanation of verbal revelation is influenced by Graeco-Roman philosophy. In this tradition there is the opinion of two thinkers, Plutarch, who believed that verbal revelation is something written by a prophet in accordance with divine inspiration and Philo, who, in contrast, believes that verbal revelation is a direct voice which gives the words of revelation. The Muslim philosophers, according to Rahman, stand between these two positions and hold that the words are the real words of revelation but are not given in words; rather they come to the prophet's intellect in a form which he is able to transmit as exact text. But the reasons for defending verbal revelation seem here to be vague, since Ibn Sīnā considers these words to be only metaphors and symbols of the truth. This can only indicate his belief that the Qur'ān expresses an unrevealed truth, which directly comes from the angels. Thus, when dealing with revelation intellectually, this language must be interpreted to return it to its intended meaning.

116 Ibn Sīnā in some of his writings uses metaphorical and symbolic language and according to Gutas the use of this method goes back to Aristotle and the Greek philosophers, who believed that philosophers must protect parts of their philosophy from the unworthy and those who have no understanding for it. Hence, they often present their philosophy in terms of allegory and symbolic language. Thus, for Ibn Sīnā, metaphorical language and allegories prevent the unworthy from misunderstanding some theological issues and simplify these to prevent sinful actions, which is one of the purposes of revealed knowledge - but not for the right reason. Nevertheless, these metaphors and allegories must contain the essence of the truth, and philosophically minded people among the masses will seek out the truth through language. See Gutas, Aristotelian Tradition, p. 299.

117 Ibid., p. 300 and also Najāt, p. 305.

118 Rahman, Prophecy, p. 44. Rahman in Prophecy in Islam translates long extracts from this treatise. The unity of God, for example, as it is presented in the language of the Qur'ān, does not in any way satisfy the philosophical concept of God's unity, according to Ibn Sīnā. He says:

The whole account of the unity [of God] in religion is in anthropomorphism. The Qur'ān does not contain even a hint to [the deeper truth about] this important problem nor a detail account concerning even the obvious matter needed about the doctrine of the unity, for a part is apparently anthropomorphic while the other part contains absolute transcendence [i.e. the total unlikeness of God to His creation] but in general terms without specification or detail.

(Ibid., p. 42) 
119 A. J. Arberry, Revelation and Reason in Islam, London: Allen \& Unwin, 1957, p. 53.

120 H. Corbin, The Visionary, pp. 28-9.

121 In Remarks and Admonitions he interprets the image of the light of God from the Qur'ānic verse about light (24:35):

Allah is the light of heaven and earth; the parable of His Light is as if there were a Niche and within it a Lamp, the Lamp enclosed in Glass, the glass as it were a brilliant star lit from a blessed Tree, an Olive neither of the East nor of the West whose Oil is well-nigh luminous, though fire scarce touch it, Light upon Light.

Ibn Sinna considers the niche, the lamp, the glass, the olive tree, the oil, which is "well-nigh luminous without touching fire," and the light upon light as symbols for the different stages of the process of thinking. The niche is the material intellect because although it has no light it has the possibility of being lit, the glass of the lamp is the intellect which has the necessary knowledge called al-aql bi-al-malaka. The olive tree is the idea which is able to illuminate the mind. The oil is intuition and when it is "well-nigh luminous without touching fire" it is the prophetic intellect and the perfection of this process is the light upon light. Al-Ghazāli in the second chapter of Mishkāt al-Anwār used Ibn Sinnā's interpretation of such verses, which disclose the process of knowledge in its highest stage of the prophetic faculty. Thus, the parable of light in the Qur'ānic chapter "on Light," Sürat al-Nūr, discloses God's light as reflected in intuition and the prophetic intellect, though the latter is always illuminated without passing through the process of knowledge.

122 Goodman, Avicenna, p. 164.

123 Ibid., pp. 152, 154.

124 Rahman, Psychology, p. 4.

125 Ibid., p. 5.

126 Ibid., p. 6.

127 Goodman, Avicenna, p. 154.

128 Ibid.

129 Ibid., pp. 149-74.

130 Ibn Sīnā, Najāt, p. 177. This certain proof, Goodman noticed, was directed by Ibn Sinna against the Muslim theologians who believed that the soul is that which provides the accident of life in the body. See Goodman, Avicenna, p. 154.

131 Ibn Sīnā, Risāla fī al-Sa' āda, p. 9.

132 Goodman, Avicenna, p. 154, see also Ibn Qayyim, al-Jawziyya Kitāb al-Ruh, Cairo: Dār al-'Anān, n.d., p. 214.

133 Ibn Sīnā, Najāt, pp. 180-1.

134 Nader, al-Nafs, pp. 31-2.

135 Ibid., pp. 41-2. See also Rahman, Psychology, p. 16.

136 Goodman, Avicenna, p. 149.

137 Ibid., pp. 157-61.

138 Ibn Sīnā, Najāt, p. 184. He gives also this argument against the reincarnation of Aṣhāb al-Tanāsukh, asserting that the soul is created only when the body is created. See also, ibid., p. 189. He also considers that the body and the soul are two substances, jawharān, which have no essential relationship, 'ilāqa dhātiyya, but rather a contingent one, 'aradiyya. They co-exist in the same time but they are not dependent on each other, therefore the death of the body does not affect the soul (ibid., p. 185). 
139 S. Inati, Ibn Sìnā and Mysticism: Remarks and Admonitions Part Four, London: Kegan Paul, 1996, pp. 75-6.

140 Ibn Sīnā, Najāt, p. 229.

141 Ibid., p. 243.

142 Ibid., pp. 245-6.

143 N. J. Bell, "Avicenna's Treatise On Love and the non-philosophical Muslim tradition," Der Islam, 1986, 63, p. 83.

144 Ibid., p. 81.

145 Ibn Sīnā, Najāt, pp. 266-7.

146 Ibn Sīnā, $F \bar{\imath}$ al-'Ishq, pp. 69-75.

147 Ibid., p. 83.

148 Ibid., pp. 83-7.

149 Inati, Mysticism, p. 79.

150 Ibn Sīnā, $F \bar{\imath}$ al-'Ishq, p. 71.

151 Ibid., p. 69. See also Netton, Allāh, p. 175.

152 I believe that he here divides beings into either beings who have love or beings whose love is their essence and existence, which means that love can be an element in the essence of all things or can be identified with the Essence and Existence (in the case of God). In short, one can say that for Ibn Sīnā God is love.

153 Ibn Sīnā, $F \bar{\imath}$ al-'Ishq (my translation), p. 72.

154 Ibn Sīnā, Najāt, p. 264.

155 Netton, Allāh, p. 176.

156 Ibn Sīnā, $F \bar{\imath}$ al-'Ishq, p. 83.

157 Inati, Mysticism, pp. 81-2.

158 Ibn Sīnā, F̄̄ al-'Ishq, p. 90.

159 Ibn Sīnā declares in the "Epilogue" of Remarks and Admonitions that he in this work will present the truth as it is in itself, but we do not find in the metaphysical part any new ideas which he did not mention in Najāt or Shif $\bar{a}$. Rather he presents his metaphysics in plausible form, explaining the problem and offering either his own solution or that of the Aristotelian tradition. The part on Sufism, however, is his new concept; it shows a mystical dimension which he hinted at in previous works but reveals here as a new method of reaching the divine world. See Gutas, Aristotelian Tradition, pp. 55-6.

160 Inati, Mysticism, pp. 81-2.

161 Ibid., p. 81.

162 Ibid., pp. 88-9.

163 Ibn Sīnā, $F \bar{\imath}$ al-'Ishq, p. 87.

164 Janssens, "Creation and Emanation," p. 462.

165 Ibn Sīnā, $F \bar{\imath}$ al-'Ishq, p. 90.

166 Jenssens, "Creation and Emanation," pp. 460-1.

167 Ibn Sīnā, al-Salāt, p. 12.

168 Ibid., pp. 12-13.

169 Ibn Sīnā, F̄̄ al-'Ishq, pp. 88-9.

170 Ibid., p. 89.

171 Inati, Mysticism, pp. 78-9.

172 Netton, Allāh, p. 176. See also Corbin, The Visionary Recital, p. 150. Ghazālī in Mishkāt uses also this image that the light of the sun veils its light so that we can only see the colours without realising the existence of light behind it. $\mathrm{He}$ uses this image to explain the problem of distinguishing things which are united together in order to show the difficulty of describing the unity with God or entering into His presence. See the sub-section titled "the concept of fan $\vec{a}$ ' in Mishkāt al-Anwār" in Chapter 4. 


\section{Notes}

173 Inati, Mysticism, p. 81.

174 Ibid.

175 Ibid.

176 L. Gardet, "La Connaissance Mystique chez Ibn Sīnā et ses Presupposés Philosophiques," Mémorial Avicenna, 2, Institut Francais d'Archeologic Orientale du Caire, 1952, pp. 39-40.

177 Ibid., p. 15.

178 Ibid., pp. 86-9.

179 Ibid., p. 89.

180 Morewedge, "Emanation and Sufism," 1, pp. 467-76, 2, 1-18.

181 Ibid., 2, pp. 1-3, 5-6.

182 Ibid., 2, pp. 3-5, 6-8.

183 L. Gardet, "Mystique chez Ibn Sīnā", p. 16.

184 Goodman, Avicenna, pp. 164-5.

185 Ibid., p. 169. See also Ibn Sīnā, Al-Ishārāt wa al-Tanbihāt (Remarks and Admonitions) ed. S. Donia, Cairo: Dār al-Ma‘ārif, 1969, pp. 272-5.

186 Ibid., p. 166.

187 Ibid., pp. 298-9.

188 Ibn Sīnā, Najāt, pp. 218-19, 224-8.

189 Ibn Sīnā, Al-Ishārāt, p. 272.

190 Inati, Mysticism, p. 89.

191 J. L. Kraemer, Humanism in Renaissance of Islam: The Cultural Revival During the Buyid Age, Leiden: Brill, p. 170, see also Abū Hāyān al-Tawhīdīe al-Imtāa wa al-Mu'ānasa, ed. Ahmad Amin, Beirut: al-Maktaba al-'Asriya, 1953, Vol. 2, p. 6.

\section{Relationship with God through self-annihilation,} fanā', according to al-Ghazālì

1 H. Lazarus-Yafeh, Studies in al-Ghazzālē, Jerusalem: Magnes Press, 1975, pp. 308-9.

2 Ibid.

3 R. M. Frank, Creation and the Cosmic System: al-Ghazātī and Avicenna, Heidelberg: Carl Winter University Press, 1992b, pp. 84-5.

4 B. Abrahamov, "Ibn Sinnā's Influence on Al-Ghazālìs Non-philosophical Works," Abr-Nabrin 1991, 29, pp. 1-3.

5 W. H. Gairdner, "Ghazālì's Mishkāt al-Anwār and the Ghazālī Problem," Der Islam, 1914, 5, p. 138.

6 Abrahamov, "Ibn Sīnās Influence on al-Ghazālī," p. 2.

7 B. Abrahamov, "Al-Ghazālīs Supreme Way to Know God," Studia Islamica, 1993,77, p. 143.

8 Al-Ghazālī, Tahāfut al-Falāsifa, ed. S. Donia, Cairo: Dār al-Ma‘ārif, 1972, pp. 63-5.

9 R. M. Frank, Al-Ghazāt̄ and the Ash'arite School, Durham, NC: Duke University Press, 1994, pp. 93-101.

10 Al-Ghazālī, al-Iqtișād fì al-I'tiqād, Cairo: al-Maṭba'a al-Maṣriyya, 1902.

11 Ibid., pp. 13-20.

12 Ibid, pp. 36-8.

13 Ibid., pp. 26-36.

14 Ibid., pp. 28-9.

15 Al-Ghazālī, Tahāfut, pp. 183-5, see also Iqtișād, p. 64.

16 Al-Ghazālī, Iqtișād, pp. 38-60.

17 F. Shehadi, Ghazālā's Unique Unknowable God, Leiden: Brill, 1964, pp. 101-3. 
18 F. Shehadi, Al-Maqșad al-Asna fì Sharb al-Asmā' al-Husna, Beirut, 1971. But I will use only the English translation here.

19 D. B. Burrell and N. Dahr, The Ninety-Nine Beautiful Names, Cambridge: Cambridge University Press, 1992.

20 Ibid., p. 6.

21 Burrell, Ninety-Nine Names, p. 18.

22 Ibid., pp. 18-19.

23 Ibid., p. 19

24 Although his discussion in Chapter 1 of the Ninety-Nine Names is rather long and complicated, it seems that he wants to show three main points. First, the meaning or the notions which these attributes create in our minds are what is meant here, not the words of the attributes. Second, he wants to show the inadequacy of language to reflect the ideas which we have in mind. The third point is that he wants to emphasize the difference between eternal reality and its reflection in the Qur'anic images.

25 Al-Ghazālī, The Niche of Lights, trans. Do Buchman Provo, UT: Brigham Young University Press, 1998c, pp. 44-53.

26 Ibid., p. 50.

27 Al-Ghazālī, Tahāfut, pp. 143-6.

28 Al-Ghazālī, Iqtișād, pp. 13-14.

29 Al-Ghazālī, Tahāfut, p. 146.

30 Ibid., pp. 90-1.

31 Ibid., Tahāfut, pp. 90-128.

32 O. Leaman, An Introduction to Medieval Islamic Philosophy, Cambridge: Cambridge University Press, 1985, p. 42.

33 Al-Ghazālī, Tahāfut, p. 135. Ibn Sīnā says in Najāt that the important conclusion for religion is that the world is dependent on God the Necessary Existent and not on the way in which it was produced. Al-Ghazālîs's protest is to ask how we can call the world God's act if it was produced naturally by necessity and beyond His control. If this were true, we should say that God was no different from any of the other elements in the chain of causes of the universe.

34 Al-Ghazālī, Tahāfut, p. 137.

35 Ibid., p. 139.

36 Ibid., p. 140.

37 Ibid.

38 Al-Ghazālī, The Alchemy of Happiness by al-Ghazāà, tran. E. L. Daniel London: Octagon Press (for the Sufi Trust), 1980, pp. 18-19.

39 Al-Ghazālī, Ibyyà 'Ulūm al-Dìn, Cairo: al-Mugald al-'Arabi, 1998a, Vol. 4, (Kitāb al-Tawhīd), pp. 304-5. Here in this passage al-Ghazālī gives a kind of symbolic recital in which the seeker speaks to the divine pen whom al-Ghazāli identifies with the angel Jibrīl and at the end of the passage he says that he is controlled by God as the pen is controlled by the writer. See also Iby $\vec{a}$, Vol. 3 ('Ajā'ib al-Qalb), p. 8. Here he says that although the angels are under constraint they are aware of, and happy in, what they are doing.

40 R. C. Zaehner, Hindu and Muslim Mysticism, Oxford: One World, 1994, p. 159. See also al-Ghazālī, Jawāhir al-Qư'àn, Beirut: Dār al-Mashriq, 1988a, pp. 29-37. Al-Ghazālī, The Niche, pp. 25-7. Lazarus-Yafeh, Studies, pp. 503-17. and al-Ghazālī, Imlà'(part of Ibya $\left.\bar{a}^{\prime}\right)$, Vol. 5, p. 51.

41 Al-Ghazālī, Ibyā', Vol. 3 ('A jā'ib al-Qalb), pp. 25, 27.

42 Al-Ghazālī, The Niche, p. 26.

43 Ibid., p. 29.

44 Ibid., pp. 25-8. 
45 Lazarus-Yafeh, Studies, p. 504. See also K. Nakamura, "Imam Ghazālī’s Cosmology Reconsidered," Studia Islamica, 1994, 80, p. 34.

46 Al-Ghazālī, Mīzān-al-'Amal, ed. S. Donia, Cairo: Dār al-Ma'ārif, 1965, pp. 202-3.

47 Ibid., pp. 203-6.

48 Al-Ghazālī, Mìzān, pp. 206-8.

49 Ibid., pp. 334-6. See also R. M. Frank, "Al-Ghazālī on Taqlīd," in Zeitschrift Für Geschichte der Arabische-Islamischen Wissenschaft, 1991-2, p. 225.

50 Al-Ghazālī, Ibyàa', Vol. 1 (Kitāb al-'Ilm), pp. 18-19.

51 Al-Ghazāî̄, Iljām al-'awāmm, in Majmu'at Rasā'il al-Imām al-Ghazāt̄̄, Beirut: Dār al-Kutub al-'Ilmiyya, 1994a, pp. 65-6.

52 Al-Ghazālī, Mìżàn, p. 406.

53 Lazarus-Yafeh, Studies, p. 361.

54 Frank, "Taqlidd," pp. 209, 215. Frank refers here to the work of F. Jabre, La notion de Certitude selon Ghazāl̄ dans ses Origines Psychologiques et Historiques, Paris: J. Vrin, 1958.

55 Frank, Taqlìd, pp. 207-8.

56 Taqlìd, al-Ghazāli explains, is related to the faculty of wahm, estimation. This faculty is the highest in the practical intellect and although it abstracts images and transfers them to ideas, these ideas are very much related to sensible experience. It presents ideas which are dependent on empirical experience as true rational concepts. They are easy to accept because of their natural appeal to the human mind. This faculty, therefore, is quite deceptive because it makes people believe that their reflections are purely rational, whereas they are in reality wholly dependent on empirical experience. Frank explains that al-Ghazāli shows in Munqidh that even the philosophers are misled by this faculty in their metaphysical principles when they depend on concepts which the mind can accept merely on the basis of familiarity. See Frank, "Taqlìd," p. 248.

57 Ibid., p. 219.

58 Ibid., p. 213. See also Iqtīsāed, p. 15 and Iljām al-'awāmm, p. 77.

59 Ibn Sīnā, Al-Najāt fi al-Hikma al-Mantiqūya wa al-Tabì'îya wa al-Ilāhīya, ed. M. al-Kurdi, Cairo: no name, 1938, pp. 3-4.

60 Frank, Taqlìd, p. 241.

61 Al-Ghazālī, The Niche, p. 37.

62 Al-Ghazālī, al-Qistās al-Mustaqūm, in Majmu'at Rasā'il al-iImām al-Ghazāt̄̄, Beirut: Dār al-Kutub al-'Ilmiya, 1986.

63 Al-Ghazālī, Mìzāan, p. 207, and The Niche, p. 37, also Ibyä', Vol. 3 ('Ajä'ib al-Qalb) p. 12.

64 Al-Ghazālī, Mìzān, p. 334.

65 Ibid., pp. 206-7, 257. In p. 257 he says that it is possible for a person to be born with the highest knowledge without any learning, as Jesus the son of Mary and other prophets were.

66 Al-Ghazālī, Ibyàa', Vol. 3 ('Ajā'ib al-Qalb), p. 27.

67 Al-Ghazāīī, Jawāhir, p. 30.

68 Al-Ghazālī, The Niche, pp. 13-14.

69 Al-Ghazālī, Ibyā', Vol. 3 ('Ajā'ib al-Qalb), p. 27.

70 F. Rahman, Prophecy in Islam: Philosophy and Orthodoxy, London: Allen \& Unwin, 1958, pp. 93-4.

71 Al-Ghazālī, Iqtișād, p. 88.

72 Al-Ghazālī, Mìzāan, pp. 257, 206-7.

73 Al-Ghazālī, Jawāhir, pp. 28-9. He says the Qur'ān is full of metaphorical ideas which aim to preserve certain wisdom veiled. 
74 Ibid., p. 33. He says the secrets of the Qur'ān should not be known by those who are not able to perceive them. Here he goes beyond the philosophers to claim that there is an esoteric side of the Qur'ān which only those deeply rooted in knowledge and mysticism can reach.

75 Nakamura, "Ghazālì’s Cosmology", p. 34, and Al-Ghazālī, Ibyyà', Vol. 4 (Kitāb al-Tawba), p. 31.

76 Al-Ghazālī, Jawāhir, pp. 18-19.

77 Lazarus-Yafeh, Studies, pp. 304-6, see also Ibya ', Vol. 3 ('Ajä'ib al-Qalb), p. 33.

78 Al-Ghazālī, Mìzāan, p. 223.

79 Al-Ghazālī, Ibya $\vec{a}$, Vol. 1 (al-'Ilm), p. 32, here writes a passage outlining the role of inspiration 'ilm al-mukāshafa and gives a long account of interpretations of the meaning of prophecy, the meaning of angels, the malakut of heaven and earth, the balance, judgement etc.

80 Al-Ghazālī, Jawāhir, p. 30. See also The Niche, pp. 16-18.

81 Al-Ghazālī, The Niche, pp. 29-33.

82 Al-Ghazālī, Ibyya', Vol. 4 (Kitāb al-Tawhìd), p. 304, and Ibyà', Vol. 3 ('Ajā'ib alQalb), p. 27.

83 Ibid., Vol. 4 (Kitāb al-Tawhīd), pp. 304-5.

84 Al-Ghazālī, Ibyàa', Vol. 3 ('Ajā'ib al-Qalb), p. 25.

85 Frank, Taqlìd, p. 230.

86 Ibid., also Ibyà ', Vol. 3, ('Ajā'ib al-Qalb), p. 25.

87 Ibid.

88 Zaehner, Hindu, p. 139. See also M. Fakhry, A History of Islamic Philosophy, 2nd edn, London: Longman, 1983, pp. 237-9. See also Al-Ghazālī, Mīzāan, p. 335.

89 Al-Ghazālī, Ibyjà, Vol. 1, pp. 116-17 (Kitāab al-'ilm). See also Mīzān, p. 335, and Daniel, The Alchemy, p. 35.

90 Daniel, The Alchemy, p. 35.

91 Ibid., p 19.

92 Al-Ghazālī, The Niche, pp. 13-14.

93 Al-Ghazālī, Ibyàa', Vol. 3 ('Ajā'ib al-Qalb), p. 8.

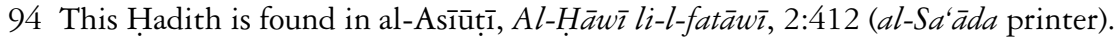

95 See al-Bukhārì: Bāb al-Isti'dhān and Muslim: Bāb al-Birr wa al-Sila.

96 These two Hadiths are often repeated in Ihyă' and he gives an explanation for them in Imlā', pp. 51-2. They are also repeated in al-Ghazālī, The Alchemy, pp. 5, 15, 17.

97 Al-Ghazālī, "On the Meaning of the Intimate Knowledge of God," in J. Renard, Window on the House of Islam, Berkeley, CA: University of California Press, 1988b, pp. 355-8.

98 Al-Ghazālī, Ibyä, Vol. 4 (Kitāb al-Mahabba), pp. 374, 375, 386.

99 Ibid, p. 374.

100 'Abd al-Halīm Mahmoud, 'Ustādh al-thā'irinn, Cairo: Dār al-Ma'ārif, 1973, pp. 317-18, 160.

101 Al-Ghazālī, Iḅyā', Vol. 4 (Kitāb Dhikr al-Mawt), p. 641.

102 Ibid., p. 298.

103 Ibid., p. 299.

104 Ibid.

105 We follow here Buchman in translating the word 'ârif as Gnostic; we believe, however, that the kind of Sufism which al-Ghazālī is introducing mainly in Mishkāt has similarities with the early Christian Sufi saints who had the following beliefs: (1) true knowledge is inspired by the divine world, (2) the human soul belongs to the divine world and its role in this world is mainly to recognize its origin and (3) the material world is to be denounced. See R. M. Grant, Gnosticism and Early Christianity, New York and London, 1959, pp. 10-13. 
However, we are mainly using the term "Gnostic" here in order to distinguish the kind of Sufism which he describes in Mishkät from that of the sälikin of Ibya $\vec{a}$.

106 Al-Ghazālī, The Niche, p. 51.

107 Ibid.

108 Ibid., p. 17.

109 Al-Ghazālī, Ibyàa', Vol. 1 (Kitāb al-'Ilam), p. 12.

110 Ibid.

111 Ibid.

112 Lazarus-Yafeh, Studies, p. 361.

113 Ibid., p. 362.

114 Ibid. p. 362.

115 Al-Ghazālī, Ibyà , Vol. 4 (Kitāb al-Tawhìd), p. 297. In addition he explains that some parts of the revealed sciences are related to "the science of mu'amala and will not be complete except by explaining it, therefore we will explain only the amount which relate to the science of mu'amala." Therefore, Lazarus-Yafeh considers that the nature of these two sciences and al-Ghazālì's wish to address both groups of readers have caused the duality and the resulting contradictions. See Lazarus-Yafeh, Studies, p. 364.

116 Al-Ghazālī, Iby $\vec{a}$, Vol. 4, pp. 79, 175, 263.

117 M. Smith explains that al-Ghazālī had absorbed much from al-Muhāsibī in his theory of prayer and trusting in God and his view that listening to music and singing is permissible for the seeker. See M. Smith, Al-Ghazāli , the Mystic, London: Luzac, 1944, pp. 124-5. He was also influenced by al-Mikkî's division of the different stages of mysticism into repentance, patience, gratitude, hope, fear, asceticism, trust, satisfaction and love. At the same time, Smith shows that al-Ghazālī accepts the fellowship and the vision of God as the basis of man's ultimate relationship. In Ihya $\vec{a}$ ' he quotes the following saying of al-Bisțāmī:

if it were granted unto you to talk with God face to face as Moses did, and to be filled with the spirit, as Jesus was, and to enjoy the divine friendship, like Abraham, yet should you seek what is beyond that, for infinitely more to be given by Him, and if you rest content with that, you are veiled thereby, and this is the test for such as these, and one who is like them, for they are in the highest rank.

Bisțāmī probably here refers to the relationship of unity with God (ibid., pp. 128-9).

118 Al-Ghazālī, Kitāb al-'Arba'īn, Beirut: Dār al-Jiyl, 1988, p. 204.

119 A. M. Schimmel, Mystical Dimensions of Islam, Chapel Hill, NC: University of North Carolina Press, 1975, p. 99.

120 Ibid., pp. 79, 175, 263.

121 Schimmel, Dimension, p. 99.

122 Ibid., pp. 314-6.

123 Ibid., p. 298.

124 Al-Ghazālī, Ibyà , Vol. 4 (al-Tawhìd), p. 297.

125 Ibid., p. 367. There are three levels of love: at the first, one experiences love towards oneself and what brings happiness. The second level is composed of love towards those who are generous and kind to oneself. The third level is the love of beauty and goodness; at this level of love the mystic experiences the attraction of the soul towards its perfection. Al-Ghazālī, Iby $\vec{a}$, Vol. 4 (al-Mababba), pp. 355-9. 
126 Ibid., p. 367.

127 Ibid., p.391.

128 Al-Ghazālì, Ibyä, Vol. 3 (al-Mababba), p. 392.

129 Ibid., p. 393.

130 Lazarus-Yafeh, Studies, p. 363.

131 Al-Ghazālī, The Niche, p.1.

132 Al-Ghazālī, Mīzan, p. 406. See also Lazarus-Yafeh, Studies, p. 361.

133 Although al-Ghazālī in $I b y \bar{a}$ ' and $M \bar{\imath} z \bar{a} n$ says that most Șûfīs are not interested in learning sciences, many Șūfīs before al-Ghazālī studied philosophy and oriental mysticism, for example, al-Junayd, al-Bisțamī and al-Hallāj, as the section titled "the concept of fan $\vec{a}$ in Mishkāt al-Anwār" of Chapter 4 shows.

134 Al-Ghazālī, The Niche, pp. 1-10.

135 Although al-Ghazāli in some parts of $I b y \vec{a}$ explains that the angels in general are all constrained to obey, here in Mishkāt he shows that they have different ranks according to their degree of light or knowledge. He identifies in Chapter 1 the two angels closest to God as Isräfil and Jibrīl. Isräfil is in a higher rank than Jibril, as he says in the following passage:

know that it has been unveiled to the possessors of insight that the lights of the dominion are likewise only to be found in hierarchy and that the light "brought nearer" is the one that is closest to the furthest light. Hence, it is not unlikely that the level of Israffil is above that of Jibrill; that among the angels is the one who is the most near because of the nearness of his degree to the lordly presence, which is the source of light.

(Al-Ghazālī, The Niche, p. 14)

See also Ibya $\vec{a}$, Vol. 3 ('Ajä'ib al-Qalab), p. 8.

136 Al-Ghazālī, The Niche, p. 20.

137 W. H. Gairdner, "Ghazālī’s Mishkāt al-Anwār," p. 138.

138 Lazarus-Yafeh, Studies, p. 308-9.

139 Ibid.

140 Lazarus-Yafeh, Studies, pp. 249-59.

141 Al-Ghazālī, The Niche, pp. 12, 63. This Hadīth is a sound one, Buchman explains, and is found in al-Termithī, Imān, 18 and Ahmad 2:176.

142 Ibid., pp. 15-16.

143 Ibid., p. 16.

144 Al-Ghazālī, Ibyā', Vol. 4 (al-Tawhīd), pp. 297-8.

145 Al-Ghazālī, The Niche, p. 18, paragraph 48. It seems to us that al-Ghazālī here divides the Sufis into scholars who are rooted in the mystic science, such as al-Junayd, and Sufis with deep mystical experience, such as al-Bistāamī and al-Hallāj.

146 Al-Ghazālī, The Niche, pp. 17, 23.

147 Ibid., p. 17.

148 Ibid., p. 18.

149 He also explains in his treaty On the Meaning of the Intimate Knowledge of God that it is not possible to know people as they know themselves. He says, "no one can know the prophet but a prophet" and "no one can know God but God." Union in this sense means for al-Ghazāli identifying fully the essence of God with the essence of the Sufi, which is technically impossible. See also the discussion on the union of the divine attributes with human attributes in The Ninety-Nine Names, pp. 151-5.

150 Al-Ghazālī, The Niche, p. 22. 
151 Al-Ghazālī, The Niche, p. 23.

152 Al-Ghazālī, Iljām, pp. 91-2.

153 Ibid., p. 23.

154 This chapter has caused a number of arguments; the first to point out the ambiguity of this chapter was W. H. T. Gairdner in his article "Ghazālī's Mishkāt al-Anwär," pp. 121-53. He singles out the problem of the image of God at the end of the chapter. This made M. Watt doubt the authenticity of this part in his article "A Forgery in al-Ghazālīs Mishkät" in The Journal of the Royal Asiatic Society of Great Britain and Ireland, 1949, pp. 5-22. Since then many scholars have argued about it and scholars such as 'Afifi, Davidson, Landolt and LazarusYafeh find Watt's assertion unconvincing. Al-Ghazālī, The Niche, p. xxvii.

155 Al-Ghazālī, The Niche, pp. 49-50.

156 Ibid. This group is probably the theologians, al-mutakallimūn. In many of his writings al-Ghazālī considers that the knowledge which the theologians had about God is not higher than that of the ordinary person because they are not able to perceive a God who is different from what they know, as explained in the discussion on taqlīd above. See above, pp. 29-30.

157 Landolt, in his article "Ghazālì and Religionswissenschaft," identifies this group as the Ismā'îlì theologians. Landolt is thinking here of such Ismā'îlì theologians as al-Sijistānī and al-Nasāfī from the ninth and tenth centuries. They recognize three main figures: God, the predecessor or the obeyed one, al-Mut $\vec{a}$, and the follower. The predecessor is the one who gives the commands and the follower is the one who carries them out. God in their theology does not have any clear role. The predecessor and the follower are two Archangels who are close to God who are symbolized by the sun and the moon, one illuminating the other. They are also symbolized in the role of the prophethood and Imamate in illuminating the human mind. Landolt, "Ghazālī and Religionswissenschaft", in Asiatische Studien, 1991, 45, pp. 43-52. See also Netton, Allāh, pp. 210-24.

158 Zaehner, Hindu, p. 156.

159 Ibid., p. 157. He explains that the Ismâ'̄il̄ consider that the relationship between God and the world is through the word "Be."

God in the Ismā'îli metaphysics is the One of Plotinus, which being absolutely one, cannot be the source of multiplicity: the necessity of the creative Word which forces both ways, so to speak - one with the One as its sole effect when it faces inward, but the cause of all multiplicity when it faces outward and similar to the idea of the Christian Logos.

160 Here, however, we should refer to a text in The Alchemy of Happiness, mentioned above, where al-Ghazāli $\overline{1}$ also considers that the angels create the world as deputies of God:

when God wills a thing it appears in the spiritual plane which is called in the Qur'ann "the Throne", from the throne it passes by a spiritual current to a lower plane called "the Chair." The shape of it appears in the "Tablet of Destiny" whence, by the mediation of the forces called angels it assumes actuality and appears on earth in form of a plant or a tree.

God's eternal ideas are transferred to the angels through one or two Archangels and they in turn carry out the actual creation in accordance with God's plan. The important point for al-Ghazālī here is the divine will which constrains and controls all the events of the world, as he shows in his descriptions of the different stages of mysticism above. 
161 Al-Ghazālī, The Niche, p. 49.

162 Ibid., p. 49.

163 In the second chapter of Mishkāt al-Ghazāli explains how to deal with a metaphorical text. He says that the content of revelation is of the upper world of the malakūt expressed in human language and parables. Hence, a text consists of utterances and meanings; if we try to understand these meaning through understanding the words as the utterances we could come to different kinds of meaning because the text, according to al-Ghazālī, is written to express metaphorical ideas. Thus the words are used only as a bridge to explain facts from the divine world; consequently their uttered meaning is not what the text aims at. The only way to interpret the text is by searching out the meanings and the facts, which the utterances seek to depict.

164 Al-Ghazālī, The Niche, p. 37.

165 Ibid., p. 38.

166 See Chapter 3, sub-secton titled "Ibn-Sinnās concept of the individuality of the human soul" above, and Najāt, pp. 245-6, 266.

167 Lazarus-Yafeh, Studies, pp. 249-59.

168 However, al-Ghazālī claims that these concepts could be taken from earlier revelations.

169 Al-Ghazālī considers, as shown above, that all muqallidūn theologians are ordinary believers.

170 This is part of a sound Hadīth; see al-Bukharī Sahih, Riqāq, 38, See Al-Ghazālī, The Niche, p. 63.

\section{Comparison and evaluation}

1 Ibn Sīnā differentiates between eternal qad̄̄m and necessary wājib. "Necessary" means that which does not depend on another and is necessarily itself, but an "eternal" thing, though it might have no point of beginning in time, could still depend on another for its existence. Thus the eternity of God is necessary while the eternity of the world is contingent. See Najāt, pp. 218, 224-5.

2 For this reason, we believe, Ibn Sīnā explored mainly the eternal knowledge and eternal existence of God but not His ability, will or perception because they imply change and therefore cannot be eternal: perception perceives a thing in its changing states, while ability and will are attributed to acts which undergo processes before, during and after other processes; therefore he does not predicate them of God.

3 See Chapter 1 sub-section titled "Early political development in Persia."

4 See Chapter 3, sub-sections titled "The essential attributes of God" and "The function of religious knowledge."

5 G. F. Hourani, "The dialogue between Al-Ghazālī and the Philosophers on the Origin of the World," Part 2, Muslim World, 1958, 48, pp. 308-14.

6 Probably this argument for "Abd al-Jabbār means that only material beings can be changed because of the inherence of the different accidents, but God as immaterial, cannot be subject to change since all His activities are due to His kind of essence.

7 See Chapter 2, sub-section titled “'Abd al-Jabbār's understanding of God's activities."

8 Ibid.

9 See Chapter 1, sub-section titled "Ibn Sīnā."

10 See Chapter 2, sub-section titled "Warning through pain and suffering." 


\section{Notes}

11 See in chapter 2: Human nature and different ways of knowledge; chapter 3: The features 9 Humans; chapter 4: The features of all Human soul, above.

12 Rahman, Islam, London: University of Chicago Press, 1966, pp. 73-7.

13 D. L. Black, "Al-Fārābī," in S. H. Nasr and O. Leaman, History of Islamic Philosophy, Part 1, New York, 1996, p. 186.

14 There are many verses in the Qur'an which show the sending of the holy spirit rüb al-Quds mainly to Jesus and the prophets but also to different believers: $2: 87,4: 171,16: 102,17: 85,26: 193,40: 15$ and 78:38. 


\section{Bibliography}

'Abd al-Jabbār, Abū al-Hasan, Al-majmū' fì al-Muh̄ị bi-al-Taklîf, ed. Sayd 'Azmī, Cairo: al-Dār al-Mașriyya lil-ta'līf wa al-Nashr, n.d.

—, Al-Mughn̄i fī Abwāb al Tawhīd wa al-'Adl, Cairo: Wizārat al-Thaqāâh wa-al-Irshād al-Qawmī, 1960-8.

—_, Mutashābih al-Qur'an, ed. A. Zarzour, Cairo: Dār al-Turāth, 1969.

—, Sharh al-Ușül al-Khamsa, ed. A. 'Uthman, Cairo: Maktabat wahba, 1996.

Abrahamov, B., "Ibn Sīnā's Influence on Al-Ghazālîs's Non-philosophical Works," Abr-Nabrain, 1991, 29, pp. 1-17.

—_ " "Abd al-Jabbār's Theory of Divine Assistance (Lutf)," Jerusalem Studies in Arabic and Islam, 1993a, 16, pp. 41-58.

—_, "Al-Ghazālī's Supreme Way to Know God," Studia Islamica, 1993b, 77, pp. 141-68.

- Divine Love in Islamic Mysticism, London and New York: Routledge, 2003.

Afnan, S., Avicenna, London: G. Allen \& Unwin, 1958.

Anawati, Georges C., Mu'allafāt Ibn Sīnā, Cairo: Dār al-Ma‘ārif, 1950.

Anawati, Georges C. and Louis Gardet, Ntroduction à la Théologie Musulmane: Essai de Théologie Compare, Paris: J. Vrin, 1948.

Arberry, A. J., Avicenna on theology, London: Murray, 1951.

- Revelation and Reason in Islam, The Forward Lectures for 1956 delivered in the University of Liverpool, London: Allen \& Unwin, 1957.

—., Muslim Saints and Mystics, London: Routledge \& Kegan Paul, 1966.

Armstrong, A. H., The Architecture of the Intelligible Universe in the Philosophy of Plotinus, Cambridge: Cambridge University Press, 1940.

- The Cambridge History of Latter Greek and Early Medieval Philosophy, Cambridge: Cambridge University Press, 1979.

Al-Ash'arī, Maqālāt al-Islāmiyyīn (Die dogmatischen Lehren der Anbänger des Islams), ed. H. Ritter, Wiesbaden: F. Steiner, 1980.

Badawī, A., Arisțū, Cairo: Maktabat al-Nahḍa al-Mașriyya, 1944.

—, Arīsțū 'inda al-'Arab: dirāsah wa-nușūs ghayr manshürah (fragments from Kitab al-Insaf of Ibn Sīnā), ed. A. Badawī, Cairo: Maktabat al-Nahḍah al-Mișrīyah, 1947.

—, Aflutin 'ind al-'Arab (Theologia Aristtotelis et fragment quae supersunt), Cairo: Maktabat al-Nahḍah al-Mișrīyah, 1955.

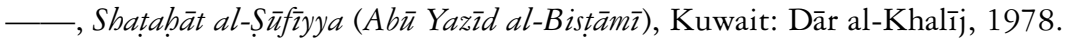

—, Madhāhib al-Islāmīyyin, Beirut: Dār al-'Ilm lil-Malāyyin, 1983.

Baqillān̄i, al-Tamb̄̄d, ed. R. J. McCarthy, Beirut: al-Maṭba‘a al-Kāthūlikiyya, 1957. 
Bell, N. J., "Avicenna's Treatise On Love and the non-philosophical Muslim tradition," Der Islam, 1986, 63, pp. 73-89.

Bello, Iysa. A., The Medieval Islamic Controversy between Philosophy and Orthodoxy Ijmā' and Ta'wīl in the Conflict between al-Ghazālī and Ibn Rushd, Leiden: Brill, 1989.

Bouyges, M., Essaides Oeuvres de al-Ghazāliz̄, ed. M. Allard, Beirut: Imprimerie Catholique, 1959; Appendix VI pp.125-6.

Brockelmann, Carl, Geschichte der arabischen Litteratur, Leiden, Holland: E.J. Brill, 1937-1949.

Burrell, D. B., "Essence and Existence: Avicenna and Greek Philosophy," Institut Dominicain d'Études Orientales du Caire: Mélanges (MIDEO), 1986, 17, pp. 53-66.

Burrell, D. B. and N. Dahr, The Ninety-nine Beautiful Names, Cambridge: Cambridge University Press, 1992.

Campanini, M., "Al-Ghazzālē," in S. H. Nasr, History of Islamic Philosophy, London and New York: Routledge, 1996, pp. 258-74.

Corbin, H., Avicenna and the Visionary Recitals, trans. by W. R. Trask, London: Routledge \& Kegan Paul, 1960.

- Temple and Contemplation: Islamic Texts and Contexts, London: KPI in Association with Islamic Publications, 1986.

Davidson, H. A., Al-Fārābì, Avicenna and Averroes on the Intellect, Oxford: Oxford University Press, 1992.

Dhanani, A., The Physical Theory of Kalām: Atoms, Space, and Void in Basrian Mu'tazī̄ Cosmology, Leiden: Brill, 1994.

Fackenheim, E. L., “A Treatise on Love by Ibn Sina," Medieval Studies, 1945, 7, pp. 208-28.

Fakhry, M., A History of Islamic Philosophy, 2nd edn, London: Longman, 1983.

_- "The Subject Matter of Metaphysics: Aristotle and Ibn Sina (Avicenna)," in Marmura, Islamic Theology and Philosophy, Albany, NY: State University of New York Press, 1984, pp. 137-47.

Al-Fārābī, Abū Nașr, Kitāb al-S̄̄yāsa al-Madaniyya: mabādí al-Mawjūdāt, Beirut: Dār al-Mashriq, 1964.

Arā' Abl al-Madīna al-Fādila, Beirut: al-Mațba'a al-Kāthūlikiya, 1968.

, Kitāb al-Mila, ed. Muhsin Mahdi, Beirut: Dār al-Mashriq, 1986.

Frank, R. M., "Several Assumptions of the Basrian School of the Mu'tazila," Studia Islamica, 1971, 33, pp. 5-18.

—, Beings and Their Attributes: The Teaching of the Basrian School of the Mu'tazila in the Classical Period, Albany, NY: State University of New York Press, 1978.

—_, "Al-Ma'dūm wa al-Mawjüd, The Non-Existent, the Existent and the Possible in the Thinking of Abū Hāshim and his Followers," Melanges de l'Institut Dominicain d'Etudes Orientales du Caire, 1980, 14, pp. 185-210.

—, "Al-Ghazālī on Taqlīd," Zeitschrift für Geschichte der Arabische-Islamischen Wissenschaft, 1991-2, pp. 207-52.

__, "Al-Ghazālī's Use of Avicenna's philosophy," Revue des Etudes Islamiques, 1992a, 57, pp. 271-85.

- Creation and the Cosmic System: Al-Ghazālì and Avicenna, Heidelberg: Carl Winter University Press, 1992b.

—_, Al-Ghazālī and the Ash'arite School, Durham, NC: Duke University Press, 1994.

Gairdner, W. H., "Ghazālīs Mishkāt al-Anwār and the Ghazālī problem," Der Islam, 1914, 5, pp. 121-53.

Gardet, L., "La Connaissance Mystique chez Ibn Sīnā et ses Presupposés Philosophiques," Mémorial Avicenna, no. 2, Institut Francais d'Archeologie Orientale $d u$ Caire, 1952, pp. 39-40. 
Al-Ghazālīe Abū-Ḥāmid, al -Iqtiṣād fī al-I'tiqād, Cairo: al-Maṭba'a al-Maṣriyya, 1902.

—_, Al-Radd al-Jamīl li Ilahiyat 'Isa bi Sarị̄̄h al-Injīl, ed. and tans. R. Chidiac, Paris: Libraire Ernest Lerox, 1939.

—, Mìzān-al-'Amal, ed. S. Donia, Cairo: Dār al-Ma'ārif, 1965.

—_, Tahāfut al-Falāsifa, ed. S. Donia, Cairo: Dār al-Ma‘āiif, 1972.

- The Alchemy of Happiness, trans. E. L. Daniel, London: Octagon Press (for the Sufi Trust), 1980.

—- Jawāhir al-Qur'ān, Beirut: Dār al-Mashriq, 1988a.

— Kitāb al-Arba'īn, Beirut: Dār al-Jīyl, 1988b.

_- Tahāfut al-Falāsifa, ed. M. Fakhri, Beirut: Dar al-Mashriq, 1990.

__, Iljām al-'awāmm in Majmū àt Rasā'il al-Imām al-Ghazālà, Beirut: Dār al-Kutub al-'Ilmiyya, 1994a.

—., Mishkāt al-Anwār, in Majmī'at Rasā'il al-Imām al-Ghazālì, Beirut: Dār al-Kutub al-'Ilmiyya, 1994 b.

—_, Al-Munqidh min al-Ḍalāl, Beirut: Dār al-Kutub al-'Ilmiyyah, 1994c.

- I Ibyà' 'Ulūm al-Dīn, Cairo: al-Mugald al-'Arabi, 1998a.

"On the Meaning of the Intimate Knowledge of God," in J. Renard, Windows on the House of Islam, London, 1998b.

, The Niche of Lights, trans. David Buchman, Provo, UT: Brigham Young University Press, 1998c.

Goodman, L., Avicenna, New York and London: Routledge, 1992.

- Islamic Humanism, Oxford: Oxford University Press, 2003.

Gutas, D., Avicenna and the Aristotelian Tradition, Leiden: Brill, 1988.

Heemskerk, M. T., Suffering in Mu'tazalite Theology: 'Abd al-Jabbār's Teaching on Pain and Divine Justice, Leiden: Brill, 2000.

Hitti, P., The History of the Arabs, London: Macmillan Press, 1970.

Houben, J. J., "Ibn Sīnā and Mysticism," in Avicenna Commemoration Volume, Calcutta: Iran Society, 1956, pp. 205-21.

Hourani, G. F., "The Dialogue between al-Ghazali and the Philosophers on the Origin of the World," The Muslim World, 1958, 48, pp. 183-91, 308-14.

—_ Islamic Rationalism, Oxford: Oxford University Press, 1971.

- Essays on Islamic Philosophy and Sciences, Albany, NY: State University of New York Press, 1975.

—_ "Deliberation in Aristotle and 'Abd al-Jabbār," in Parviz Morewedge, Islamic philosophy and Mysticism, Delmar, NY: Caravan Books, 1981, pp. 151-62.

- "A Revised Chronology of Ghazālīs Writings," Journal of American Oriental Society, 1984, 104, pp. 289-302.

Ibn al-Murtaḍā, Aḥmed Ibn Yahyā, Firq wa Ṭabaqāt al-Mu 'tazilah, ed. A. al-Nashaar, Cairo: Dār al-Maṭbu'āt al-Jami'iyya, 1972.

Ibn Qayyim, al-Jawziyya, Kitāb al-Ruh, Cairo: Dār al-'Anān, no date.

Ibn al-Rushd, Abū Wal̄id, Tahāfut al-Tahāfut, ed. S. Donia, Cairo: Dār al-Ma‘ārif, 1999.

Ibn Sīnā, Risāla fi al-Qadar, ed. M. Mehren, in Trait'es Mystique d'Avicenna, IV, Leiden: Brill, 1899.

—, Risāla fì Mābiyyat al-Ṣalāt (The Treatise on the Nature of Prayer), in Jāmi‘ al-Badā'i', Cairo, 1917a.

—, Risāla fì al-'Ishq (The Treatise on Love), in Jāmi' al-Badā' $i^{\prime}$, Cairo, 1917b.

_., Al-Risāla al-'Arshiyya, in Majmū'at Rasā'il al-Shaykh al-Ra'is, Hyderabad: Osmania Press, 1935a. 


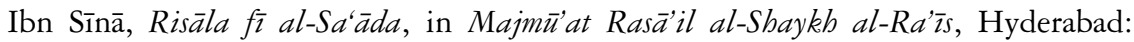
Uthmaniya Press, 1935 b.

—, Al-Najāt fi al-Hikma al-Mantiqūya wa al-Ṭabìnya wa al-Ilāhīya, Cairo: Muhy al-Din al-kurdi, 1938.

—, Avicenna's De Anima (in al-Shifä'), trans. F. Rahman, Oxford: Oxford University Press, 1960a.

—_, Al-Shifa', al-Ilāhiyyat, 2 Vols, ed. G. C. Anwati, Cairo: Dār al-Kitāb al-'Arabī lil-Tiba'ah wa-al-Nashr, 1960b.

—, Al-Ishārāt wa al-Tanbīhāt (Remarks and Admonitions), ed. S. Donia, Cairo: Dār al-Ma'ārif, 1969.

——, Al-Ta'l̄̄qāt, ed. A. Badawi, Cairo: al-Hay'ah al-Mịșrīyah al-`Āmmah lil-Kitāb, 1973.

- The Life of Ibn Sin̄ā: A Critical Edition and Annotated Translation, ed. and trans. Gohlman, William E., Albany, NY: State University Press, 1974.

—, Commentary on Theologia Aristotelis, ed. A. Badawi 1958 repr. Aristu 'Ind al-'Arab, Koweit: Al-nāshir Wkālat al-Mațbuāt, 1978, 35-74.

Inati, S. C., Ibn Sīnā Remarks and Admonitions, Part one, Toronto: Pontifical Institute of Mediaeval Studies, 1984.

Inati, S. C., Ibn Sīnā and Mysticism: Remarks and Admonitions part four, London: Kegan Paul, 1996.

- The problem of evil: Ibn Sina's theodicy, Binghamton, NY: Global Publications, 2000.

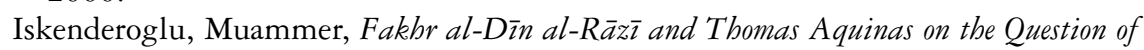
the Creation of the World, Leiden: Brill, 2002.

Jabre, F., La Notion de Certitude selon Ghazālī dans ses Origines Psychologiques et Historiques, Paris: J. Vrin, 1958.

Janssens, J., "The Problem of Human Freedom in Ibn Sīnā," in Patronat d'Estudis Osonencs, 1996 (Sèrie “Actes," 1) pp. 112-18.

- "Creation and Emanation in Ibn Sīnā," Documenti e Studi sulla Tradizione Filosofica Medievale, 1997, 8, pp. 455-77.

Kraemer, Joel. L., Philosophy in the Renaissance of Islam: Abū Sulaymān al-Sijistānī and His Circle, Leiden: Brill, 1986.

- Humanism in Renaissance of Islam: The Culture Revival During the Buyid Age, Leiden: Brill, 1992.

Landolt, A., "Ghazālī and Religionswissenschaft," Asiatische Studien, 1991, 45, pp. 19-72.

Lazarus-Yafeh, H., "Place of the Religious Commandments in the Philosophy of Al-Ghazālī," Muslim World, 1961, 51, pp. 173-84.

- Studies in al-Ghazzālī, Jerusalem: Magnes Press, 1975.

Leaman, O, “ 'Abd al-Jabbār and the Concept of Uselessness," Journal for the History of Ideas, 1980, 41, pp. 129-31.

—, An Introduction to Medieval Islamic Pbilosophy, Cambridge: Cambridge University Press, 1985.

McCarthy, R. J., Freedom and Fulfillment: An Annotated Translation of Al-Ghazāt̄̄'s al-Munqidh min al-Dalāl and Other Relevant Works of al-Ghazāt̄̄, Louisville, KY: Fons Vitae, 1999.

Mahmoud, 'Abd al-Halim,'Ustādh al-thā'irīn, Cairo: Dār al-Ma'ārif, 1973.

Marmura, M. E., "Avicenna and the Problem of the Infinite Number of Souls," Mediaeval Studies, 1960, 22, pp. 232-9. 
"Some Aspects of Ibn Sinnās Theory of God's Knowledge of the Particular," Journal of the American Oriental Society, 1962, 82, pp. 299-312.

—, Ibn Sìnā fì Itbbāt al-Nubbuwwāt, Beirut: Dār al-Mashriq, 1968.

- "The Metaphysics of Efficient Causality in Avicenna (Ibn Sīnā)," in Islamic Theology and Philosophy: Studies in Honour of G. F. Hourani, Albany, NY: State University Press, 1984a, pp. 172-87.

- Islamic Theology and Philosophy: Studies in Honour of George F. Hourani, Albany, NY: State University Press, 1984b.

Massignon, L., "Le Christ dans les Evangiles selon al-Ghazālī" in the Revue des Etudes Islamiques, 6, 1932, pp. 523-36.

Al-Māturīēie, Abū Manșūr, Kitāb al-Tawhìd, ed. F. Khulayf, Alexandria: Dār al-Jami'āt al-Mașriyya, n.d.

Mehren, A. F., Rasā'il al-Shaykh al-Ra's̄s Ab̄̄ Alì al-Husayn ibn 'Abd Allāh ibn Sīnā fī Asrār al-bikmah al-mashriqūyah, Leiden: E.J. Brill, 1889-1899.

Michel, T. F., A Muslim Theologian's Response to Christianity (Ibn Taymiyya's al-Jawāb al-Sab̄hb), New York: Caravan Books, 1984.

Morewedge, P., "The Logic of Emanation and Sufism in the Philosophy of Ibn Sinnā (Avicenna)," Part I and II, Journal of the American Oriental Society, 1971, 91, pp. 467-76, 1972, 92, pp. 1-18.

$\longrightarrow$, Islamic Philosophy and Mysticism, Studies in Islamic Philosophy and Science, Delmar, NY: Caravan Books, 1981.

Muslim, al-Hajaj, Șahīh Muslim, trans. Abdulhamid Siddiqi, Lahore: Ashraf, 1971.

Nader, Albeer, al-Nafs-al-Bashariyya 'ind Ibn Sīnā, Beirut: Dār al-Mashriq, 1968.

Nakamura, K., "Imam Ghazālīs Cosmology Reconsidered," Studia Islamica, 1994, 80, pp. 29-46.

Nasr, S. H., An Introduction to Islamic Cosmological Doctrines: Conceptions of Nature and Methods Used for its Study by Ikhwān al-Șafä, al-Birūn̄i and Ibn Sìnā, Cambridge, MA: Harvard University Press, 1964.

Nasr, S. H. and Leaman, Oliver, History of Islamic Philosophy: Routledge History of the World Philosophy, 1, 1996, London and New York: Routledge.

Netton, I. R., Allāh Transcendent, London and New York: Routledge, 1989.

- Muslim Neoplatonists, An Introduction to the Thought of the Brethren of Purity (Ikhwān al-Șafä'), Edinburgh: Edinburgh University Press, 1991.

Nicholson, R. A., The Mystics of Islam, London: Routledge, 1963.

Ormsby, Eric L., Theodicy in Islamic Thought, Princeton: Princeton University Press, 1984.

Peters, J. R. T. M., God's Created Speech: A Study in Speculative Theology of the Mu'tazili Qādì al-Qudāt Abū al-Hasan 'Abd al-Jabbār Ibn Aḅmad al-Hamdhān̄̄, Leiden: Brill, 1976.

Pines, S., "La Philosophie Orientale d'Avicenna et la polemique contre les Baghdadiens" Achives d'Historie Doctrinale et Litt'eraire du Moyen Age, 1952, 27, pp. 5-37.

Pretzel, Otto, "Die Frühislamische Attributenlehre: ihre weltanschauliche Grundlagen und Wirkungen," in Sitzungsbericht der Bayerischen Akadamie der Wissenschaften, Philosophisch-bistorisch Abteilung, 4, 1940, München.

Rahim, Acar, Talking about God and Talking About Creation: Avicenna's and Thomas Aquinas' Positions, Leiden: Brill, 2005.

Rahman, F., Avicenna's Psychology: An English Translation of Kitāb al-najāt, Book II, Chapter VI, with Historico-philosophical Notes and Textual Improvements on the Cairo edition, Oxford: Oxford University Press, 1952. 
Rahman, F.,, Prophecy in Islam: Philosopby and Orthodoxy, London: Allen \& Unwin, 1958.

—, Avicenna's De Anima (al-Shifä'), Oxford: Oxford University Press, 1959.

—, Islam, London: University of Chicago Press, 1966.

__ , "Essence and Existence in Ibn Sīnā: The Myth and Reality," Hamdard Islamicus, 1981, 4, 1, pp. 3-14.

Renard, J., Windows on the House of Islam, Berkeley, CA: University of California Press, 1998.

Ross, C. D., The Right and the Good, Oxford: Clarendon Press, 1930.

Al-Șafadī, Șalah al-Dīn Ibn Ibak, al-Wāfi Bayn al-Wafyyāt, Istanbul: Matba'at al-Dawla, 1931.

Schimmel, A. M., Mystical Dimensions of Islam, Chapel Hill, NC: University of North Carolina Press, 1975.

Shehādi, F., Ghazālī's Unique Unknowable God, Leiden: Brill, 1964.

Smith, M., "Al-Ghazāli on the Practice of the Presence of God," The Muslim World, 1933, 23, pp. 16-23.

- "The Forerunner of al-Ghazālī (al-Muhāsibī)," Journal of the Royal Asiatic Society, 1936, pp. 65-78.

—, Al-Ghazātī, the Mystic, London: Luzac, 1944.

—, Räbi'a the Mystic and Her Fellow-saints in Islam, Oxford: Oneworld, 1994.

Stoddart, W., Sufism: The Mystical Doctrines and Methods of Islam, Wellingborough, Northampton: Thorsons Publishing Group, 1976.

al-Subkī, Tāj al-Dīn Ibn Nasr, Ṭabaqāt al-Shāfíiyya, Cairo: Maṭba'at 'Isa al-Bābī al-Halabī, no date.

Al-Tawhīī̄i, Abū Hāyān, al-Imtā' wa al-Mu'ānasa, ed. Ahmad Amin, Beirut: al-Maktaba al-'Așriyya, 1953.

'Uthman, A., al-Khilāf bayn al-Skaykhayn, Cairo: Mktabat Wahba, 1968.

Van Ess, J., Die Gedenken Welt des Hārith al-Muhāsibī, Bonn: Bonn University, 1961.

—_, "Ibn Kullāb und die Mihna," Oriens, 1965-6, 18-19, pp. 92-142.

_. Theologie und Gesellschaft im 2. und 3. Jahrhundert Hidschra, 3, 4, 1991, Berlin and New York.

Watt, M. W., "Authenticity of Works Attributed to al-Ghazālī', Journal of Royal Asiatic Society, 1952.

—, Muslim Intellectual, Edinburgh: Edinburgh University Press, 1963.

Watt, M. W., Islamic Revelation in the Modern World, Edinburgh: Edinburgh University Press, 1969.

- The Formative Period of Islamic Thought, Edinburgh: Edinburgh University Press, 1973.

Wolfson, H. A., "Albinus and Plotinus on the Divine Attributes," in H. A. Wolfson, Studies in the History of Philosophy and Religion, Harvard and Cambridge, MA: Harvard University Press, 1973a, pp. 115-30.

—_, "Avicenna, al-Ghazzālī and Averroes on Divine Attributes," in H. A. Wolfson, Studies in the History of Philosophy and Religion, Harvard and Cambridge, MA: Harvard University Press, 1973b, pp. 143-70.

—_ "Philo Judaeus," in Studies in the History of Philosophy and Religion, Harvard and Cambridge, MA: Harvard University Press, 1973c, pp. 60-71.

- Studies in the History of Philosophy and Religion, Harvard and Cambridge, MA: Harvard University Press, 1973d. 
- "The Knowability and Describability of God in Plato and Aristotle," in H. A. Wolfson, Studies in the History of Philosophy and Religion, Harvard and Cambridge, MA: Harvard University Press, 1973e, pp. 98-114.

— The Philosophy of Kaläm, Cambridge, MA and London: Harvard University Press, 1976.

Zaehner, R. C., Hindu and Muslim Mysticism, Oxford: One World, 1994. 



\section{Index}

Abbasids 9-12, 13, 14, 17, 30

Abi'l-Khayr, Abū Sa'īd Ibn 26

Abraham 128, 198 n.118

al-'Adawiyya, Rābi'a 36-7

'Adi, Ibn 9, 16

Ahl al-Ithbāt 34-5

Ahl al'Jamā'a wa al-Sunna 15, 34

Ahmad, Ibn Ismā̄īl 11

Aḥmad, Naṣr Ibn 19

Akhshīdiyya 18

Alleppo 14

Alptigin 13

al-Amīd, Abū al-Fạ̣l 16

al-Amin 11

Al-'Āmirī 19-20, 77

al-Amis, Ibn 19

Aphrodisias, Alexander of 93-4, 115

Armenia 13

Arsalān, Alb 13-14, 17

Asadabād 20

Ashāa al-Aṣlah 35, 64, 71, 184 n.97

Ashāb al-Tanāsukh see Barahima, Indian

al-Ash'ari 15; accidents 177 n.3;

crisis 176 n.111; difference with

Mu'tazilites 46, 180, 184; divine

assistance 34-5; Maqālāt 185 n.25;

refutation of 21

Ash 'arites: Ash 'arī Sunnī Islam 15;

Baqillān̄ 38 ; criticism of 'Abd al-Jabbār

57; divine attributes 81, 122-4, 153,

178 n.8, 180 n.37; knowledge 131;

Qur'ān 61; theology 14, 21, 29-30, 184 n. 105

Avicenna see Ibn Sīnā

Baghdad: intellectual activities 19-21; Nizāmiyya school 17; role of caliphs 10-16; school of al-Muhāsibī 37-8; school see Mu'tazilites, Baghdādī
al-Baghdādī 9

Bakr, Ibn 14

al-Balkhī, Abū al-Qāsim 21;

Abu Zayd 19

al-Baqillān̄i 9

al-Bāqir, Muhammad 14

Barāhima, Indian 3, 71, 183 n.86

al-Bașrī, Abu Abdullah 18, 21

Bațīnites 15

Begh, Tughril Sultan 13, 16

al-Bisțāmī, Abū Yazid: annihilation 38-40, 137,177 n.152; relationship with divine 167, 198 n.118; Sufis $113,135,146-7$, 150, 199 n.135

Brethren of Purity 37-8, 118

Buhāshimiyya 14, 17, 18, 21

Buhay, Abu Shujā 'Ibn 11

Bukhārā 15, 19, 26

Buyids 10-13, 16, 25

Cairo 10, 15, 17, 173-9, 184-9, 191-2, 194-7,

Caliphs 10-11

Christians 3, 31, 36, 79, 197 n.105, 200 n. 161

Damascus 31

Dār al-'Ilm 17

Daylamites 11, 14

al-Dawla: 'Aḍud 12, 15, 21; 'Alā 16; al-Habash̄̄ 16; Bahā' 13, 15; Bakhtyār 12, 16; Fakhr 13, 16, 18, 21-3;

'Imād 12; Majd 22, 26; Mu'ayid 12-13, 16, 18, 21; Mu'iz 12, 16;

Rukn 12, 16, 18; Ṣamșām 13;

Shams 16, 22, 26; Sharaf 13;

Yamīn 13; see also Buyids

Egypt 10, 31 
al-Fārābī 9; emanation theory 114, 188;

God's activities 47-51, 155-7; influence on al-Ghazālī 132; influence on Ibn Sīnā 81, 85, 93, 97, 169; knowledge 52-6, 60-2, 160-3; love 37; metaphysics 33; school 16, 19

Fardajān 27

al-Farmādhī, Abū 'Al̄̄ al-Faḍl Ibn Muhammad Ibn 'Alī 29

Fars 11-12

Fāṭimids 10, 14, 15

al-Ghazālī 3-9, 11, 176; attributes of God 122-5; career 17, 19-20; creation 126-9; divine activity 155-6; divine grace 51; divine love 36; evaluation 153-4, 157-8; intellect 130-5; knowledge 46, 148-50, 160-2, 196-8; life and works 30-4; mystics 151, 163, 165-7, 177-8, 195, 199, 200-1; revealed sciences 169-71; self-annihilation 119-21, 138-45; soul 136-7; Sufis 73, 118, 145-7, 175 n.101

Ghaznawids 13, 16, 25-6

Gnostics 197-8 n.105; knowledge 68; mystics 2, 5, 121; Sufis 113, 138-9, 145

al-Habashī 16 al-Hajjaj, Ibn 16 al-Hakam, Hishām Ibn 16, 53

al-Hallāj 9, 31, 39

Hamadhān 16, 21-2, 26-7, 75

Hamadānids 12

Hanabalites 14-16, 20, 75

Hanbal, Ahmmad Ibn 15

Harb, Ja'far Ibn 35

Hārūn al-Rashīd 10, 16

al-Hasan, Ibn al-Ațrash 11

al-Hasan, Ibn Zayd 11

al-Hasan, i-Ṣabbah 15

al-Hasan̄, Yehīa Ibn 'Abdullah 11

al-Hudhayl, Abu 9, 178; atomism 2, 177 n.3, 180-1 n.42; divine assistance 35; salons 16; school at Bașra 43, 46 al-Ḥusayn, Ṭāhir Ibn 11

Ibn Rushd 30, 74, 96, 119-20, 144, 154,203

Ibn Sīnā 3-7, 192-3, 201; characteristics of God 46, 78-84; criticism of 33; divine activity 156-9; divine light 110-16; divine love 36, 38, 103, 106-9;

features of mankind 90; generation of world 85-9, 189, 195 n.33; God and humans 152-5, 164-5, 167, 188; ideas 93-5; influence on al-Ghazālī 120, 123-6, 133-6, 142, 149-50; influences 19-20, 117-18; interpretation of Qu'rān 101-2; intuition 169; knowledge 130-2, 160-3,171-1, 190; language 191; life 11, 15-16, 18; soul 91, 96-100, 104-5, 129; works 25-9

Ikhwān al-Ṣāfa see Brethren of Purity

Imāmiyya 14

Imāms 10, 11, 14-15, 30, 166, 200 n.159

Iraq 12,30

Ișfahān 11, 13-14, 16-17, 22, 25, 27,75

al-Ișfahan̄i, Abū al-Farāj 16

Ismā'îlīs 10, 14-15, 19, 20, 25, 148,200

Ismā'îlliyya 14

Ithnā 'Ashrīyya 14

al-Jabbār, Abd 174, 178-81; assistance on basis of specific needs 66-8; divine assistance 34, 36, 41-6, 63-5, 184-5; life and works 20-5; Mu'tazilites 3-11; pain 69-72, 186; Rayy school 14-16, 18; reflection 57-9, 182-3

al-Jubā'̄ 9, 18, 21, 23; Abū 'Ali 36; Abū Hāshim 14

al-Junayd: Baghdād school 2, 9, 37-9; mystics 170, 199 n.135;

soul 177 n.146; Sufis 113, 135, 139, 140, 150-1

Jurjān 11, 26

al-Juwāynī, Abū al-Ma'ālī 20, 29

al-Jūzjān̄ì 26-7, 118

Kharmmithan 15, 25-6

Khawārizm, Prince 'Ā̄ Ibn Mam'ūn 26

Khurāsān 10-11, 13, 16-20, 74, 76-7, 120

Khuzistān 21

al-Kindī 2, 9, 19, 37, 43

Kirmān 11-12

Kullāb, Ibn 34

al-Mahdī, Muhammad (al-Qā'im) 14

Malikshāh 13, 17

al-Ma'mūn, Caliph 10-11, 14-15 
Mankadim 15, 23

Manzikart, battle of 13

Mattawiyya, Abu Muhammad al-Hasan Ahmad Ibn 23

Mecca 31

al-Mikkī 139-40, 198 n.118

al-Muhallabī, Abu Muhammad 16

Muhammed 114, 148

al-Muhāsibīi 9, 37-8, 139-40, 198 n.118

al-Mulk, Nizāām 13, 15, 17, 29, 173

Muradwidge, Ibn Zyar 11

al-Murtadā, Ibn 22

al-Mustakfí, Caliph 12

al-Mustzhirī 30

al-Mu'tadud, Caliph 10

al-Mu'tamir, Bishr Ibn 25, 36, 53, 63

al-Mu'tașim, Caliph 10

al-Mutawakil 10, 14

Mu'tazilites 1-3, 16, 20-5, 37, 41, 45, 64-5, 67, 68, 73, 98, 172-3; al-Jabbār 3, 25, 54-6, 58, 73, 168-9; attribution 44, 46-8; Baghdādī 21, 53, 63-5, 177 n. 3; Bașrian 22-4, 35-6, 42-3, 52, 67-8; debate with Ash'arites 81, 180 n.37; Qur'ān 60-2, 153; Rayy 15; relationship with Shāf'i 20 ; schism 18, 173 n.63; theology 14, 16, 37, 41, 51, 89, 159

al-Muțî̀ 12

al-Muzaaffar, Mu'nis 10

mystics: al-Mikkî’s division 198 n.118;

Baghdād school 2; cultural context 9, 36-9; differences from theology 65-6; Gnostics 68; Hadīth 177 n.151; love 106; mystical philosophy 118; mysticism of al-Ghazālī 3-7, 73, 119, $121,151,153,161$; mysticism of Ibn Sīnā 74-7, 90, 110, 113-15; Sufis $136-41,146-7,165-7$; vision of God 143

al-Nașībīn̄i, Abū Isḥāq 21

al-Natelī, Abū Abdullah 25

Nīshāpūr 16-18, 29

al-Nīshāpūrī, Abū Tammān 19

Nizāmiyya 16-17, 20, 29, 32, 120

Persia 3, 10-11, 14, 25

Philo Judaeus 80-1, 187, 191

Plato 19, 77, 97, 155; cosmology 36-7; ideas 80,92 ; soul 104

Plotinus 77; divine attributes 81-2, 155; Enneads 27-8, 120; Plotinian One 37,
84-5, 114-15, 148, 200 n.161;

soul 104

Plutarch 191 n.115

Porphyry 115

Preserved Tablet 128-30, 132-5, 144, 150-1, 160-1

Qabūs, Shaykh al Ma'alī 26

Al-Qādir, caliph 15

Qayyim, Ibn 104-5, 192

Qur'ān: al Ghazālī 89, 123-5, 127-8, 130, 132, 193; al-Jabbār 182 n.74, 183 n.85; authorized version 168 ; creation 200 n.162; divine attributes 46, 155;

divine love 37; esoteric aspect 197 n.74;

Ibn Sīnā 83, 87, 99-102, 117;

inimitability of 60-1; interpretation of 30, 169-71, 191 n.115;

knowledge 132-5, 151, 159;

religious knowledge 161; revelation

of God 1, 2, 43, 81, 166;

temporal nature 15

Qurțuba 10,17

al-Rādīi, Caliph 11-12

Ramhurmuz 21

al-Rahman III, 'Abd 10

al-Rashīd, Hārūn 10, 16, 174 n.63

al-Rawandī, Ibn 22

Rayy 10-11, 17-18, 21, 26

Romanus Diogenes 13

Sabaeans 3

Saffarids 10

al-S̄ạhib, Ibn 'Abbād 16, 18, 21-2

Saljūqs $10-11,13-14,16-17$

Sāmān 11

al-Sāmānī, Prince Nūḥ Ibn

Manșūr 15, 26

Sāmānids 10-11, 13

Sammarra 10

al-Sāqtīi, Sārī 2

al-Saymarī 18

al-Sayyda Shirin 22

Sebakatakin 12

Shāf'i 16-18, 20, 29

Shāhīn, 'Umar Ibn 12

Shi' ites 10-12, 14, 16, 20

Shirāz 10,17

al-Sijistān̄i 9, 19, 118, 200 n.159

Spain 10

Subuktigen 13

al-Suhaītīi, Abū al-Hasan 26 


\section{Index}

Sumaniya 3

Sufis: al-Junayd 113; al-Ghazālī 30-4, 73, 139, 148, 175 n.101, 176 n.111, 199; annihilation 38-9, 112, 119-21, 123, 125, 128; divine love 36-7; evaluation 156-9, 161, 165-7, 170, 197-8 n.105; influence on Ibn Sīnā 7, 26, 28-9, 76-8, 87, 109, 193 n.59; prophecy 134; relationship with God 4, 90, 137-9, 177 n.150; saints 140-3, 145-151; soul 53-4, 102-3, 105, 114, 135-6; school of al-Juwāynī 20; transcendence 117-18

Sunn̄̄ 9-10, 15, 17, 46,

Syria 14

Ṭāharids 10

Ta līmiyya Bātẹ̄nīyya 20

al-Tawhidī, Abu Hayyan 9, 18-19

Thanāwiyya 69,185 n.125
Tuūlūn, Ibn 10

Ṭūs 29, 32

al-Tustārīi, Sahl 9

Ṭutūsh 14

'Umar 14

Umayyad ruler 10

'Uthmān 14

Vishka 181 n.42

Yahya the Barmakide 16

Yemen 3, 14, 23

Zayd 59, 91

Zaydīs 11,14

Zaydiyya 14

Zenj 10

Zoroastrians $11,77-8$ 